U. S. DEPARTMENT OF COMMERCE NATIONAL BUREAU OF STANDARDS

\title{
REPORT OF THE \\ THIRTY-FOURTH NATIONAL CONFERENCE \\ WEIGHTS AND MEASURES
}

ATTENDED BY REPRESENTATIVES

FROM VARIOUS STATES

SPONSORED BY THE NATIONAL BUREAU OF STANDARDS

WASHINGTON, D. C., MAY 24, 25, 26, and 27, 1949

MISCELLANEOUS PUBLICATION 195 



\title{
U. S. DEPARTMENT OF COMMERCE CHARLES SAWYER, Secretary \\ NATIONAL BUREAU OF STANDARDS \\ E. U. CONDON, Director
}

MISCELLANEOUS PUBLICATION 195

\section{REPORT OF THE}

\section{THIRTY-FOURTH NATIONAL CONFERENCE}

\section{ON \\ WEIGHTS AND MEASURES}

\author{
ATTENDED BY REPRESENTATIVES \\ FROM VARIOUS STATES
}

SPONSORED BY THE NATIONAL BUREAU OF STANDARDS

WASHINGTON, D. C., MAY 24, 25, 26, and 27, 1949

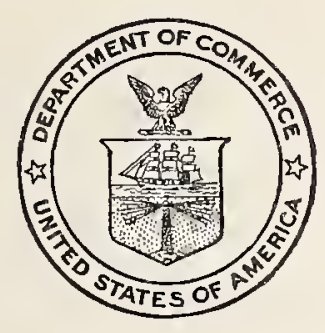

UNITED STATES

GOVERNMENT PRINTING OFFICE

WASHINGTON : 1950 



\section{OFFICERS AND COMMITTEES}

\section{OFFICERS}

(Present and serving during the Thirty-fourth National Conference)

President: E. U. Condon, Director, National Bureau of Standards, Washington, D. C.

Vice Presidents :

R. S. Ackerman, Superintendent, City Department of Licenses, Weights, and Measures, Minneapolis, Minn.

Nalls BerRyman, Supervisor, State Division of Weights and Measures, Tallahassee, Fla.

V. D. CAMPBELl, Deputy State Sealer, Columbus, Ohio.

E. R. Fisher, State Sealer of Weights and Measures, Providence, R. I.

Robert Williams, County Sealer of Weights and Measures, Mineola, N. Y.

Secretary: R. W. Smith, Chief, Office of Weights and Measures, National Bureau of Standards, Washington, D. C.

Treasurer: G. F. Austin, Jr., Deputy Sealer of Weights and Measures, Detroit, Mich.

(As elected by the Thirty-fourth National Conference for the ensuing year)

President: E. U. Connon, Director, National Bureau of Standards, Washington, D. C.

Vice Presidents :

C. A. BAKEr, Director, State Bureau of Weights and Measures, Department of Agriculture and Markets, Albany, N. Y.

J. F. Brenton, Chief, State Bureau of Weights and Measures, Department of Agriculture, Sacramento, Calif.

A. J. Jensen, Chief State Inspector of weights and Measures, Public service Commission, Jamestown, N. D.

J. T. Kennedy, Director, Department of Weights, Measures, and Markets, District of Columbia, Washington, D. C.

J. P. Leonard, City Superintendent of Weights and Measures, Paterson, N. J.

C. C. Mundy, Chief, City Bureau of Weights and Measures, Richmond, Va.

Secretary: R. W. SmIтH, Chief, Office of Weights and Measures, National Bureau of Standards, Washington, D. C.

Treasurer: G. F. Austin, Jr., Deputy Sealer of Weights and Measures, Detroit, Mich. 


\section{EXECUTIVE COMMITTEE}

(As elected by the Thirty-fourth National Conference)

$\left.\begin{array}{l}\text { E. U. Condon } \\ \text { C. A. BakeR } \\ \text { J. E. BREnToN } \\ \text { A. J. Jensen } \\ \text { J. T. KENNEDY } \\ \text { J. P. LeONARD } \\ \text { C. C. MUNDY } \\ \text { R. W. SMITH } \\ \text { G. F. AUSTIN, JR. }\end{array}\right\}$ Ex officio.

C. D. Baucom, State Superintendent of Weights and Measures, Raleigh, N. C.

J. A. Bernard, City Commissioner of Weights and Measures, St. Louis, Mo.

A. F. Crappuis, Chief, State Division of Weights and Measures, Baton Rouge, La.

C. G. CrocketT, City Inspector of Weights and Measures, Baltimore, Md.

E. R. Fismer, State Sealer of Weights and Measures, Providence, R. I.

F. M. Greene, Deupty Commissioner, State Food and Drug Commission, Hartford, Conn.

H. E. Howard, City Inspector of Weights and Measures, Miami, Fla.

W. A. Kerlin, County Sealer of Weights and Measures, Oakland, Calif.

I. M. Levr, City Sealer of Weights and Measures, Chicago, Ill.

C. D. Lin r, County Sealer of Weights and Measures, Towson, Md.

J. P. McBride, State Director of Standards and Necessaries of Life, Boston, Mass.

C. H. OAKLEY, State Inspector of Weights and Measures, Cheyenne, Wyo.

L. R. Roper, Supervisor, City Division of Licenses and Standards, Seattle, Wash.

A. T. Smitr, Assistant Superintendent, State Division of Weights and Measures, Trenton, N. J.

R. D. Trompson, Supervisor, State Weights and Measures Section, Richmond, Va.

\section{STANDING COMMITTEES}

(The membership of standing committees, as shown below, conforms to the action of the Thirty-fourth National Conference in standardizing the membership of such committecs at $\mathbf{5}$ members, but with the stipulation that the membership of these committees be not arbitrarily reduced, but be allowed to reach the new figure automatically as members retire or as their terms expire under the plan for rotating membership. As reported, the membership includes appointments announced at the Thirty-fourth National Conference. See pages 4 and 6 of this report.

Chairmen and Secretaries of Committees, as reported, are as determined by each committee for the ensuing year. The term of office for each committee member, in years, is shown by the figure in parenthesis following each entry.)

\section{COMMITTEE ON SPECIFICATIONS AND TOLERANCES}

J. P. McBride, State Director of Standards and Necessaries of Life, Boston, Mass., Chairman. (4)

R. W. Smiтh, Chief, Office of Weights and Measures, National Bureau of Standards, Washington, D. C., Secretary. (1)

G. F. Austin, Jr., Deputy City Sealer of Weights and Measures, Detroit, Mich. (2)

NALLS Berryman, Supervisor, State Division of Weights and Measures, Tallahassee, Fla. (3)

L. E. WiтT, City Sealer of Weights and Measures, Milwaukee, Wis.

\section{COMMITTEE ON METHODS OF SALE OF COMMODITIES}

J. F. Blickley, Director, State Bureau of Standard Weights and Measures, Harrisburg, Pa., Chairman. (2)

R. S. AcKerman, Superintendent, City Department of Licenses, Weights, and Measures, Minneapolis, Minn. (3)

C. D. Bavcom, State Superintendent of Weights and Measures, Raleigh, N. C. (5)

J. A. Borle, Deputy State Sealer of Weights and Measures, Augusta, Me. (1).

J. G. Rogers, Deputy State Superintendent of Weights and Measures, Trenton, N. J. $(6)$

L. R. Roper, City Supervisor of Licenses and Standards, Seattle, Wash. 


\section{COMMITTEE ON LEGISLATION}

R. E. MeEk, Director, State Division of Weights and Measures, Indianapolis, Ind., Chairman. (6)

C. A. BAкer, Director, State Bureau of Weights and Measures, Albany, N. Y. J. A. Bernard, City Commissioner of Weights and Measures, St. Louis, Mo. J. R. Boотн, City Sealer of Weights and Measures, Haverhill, Mass. (5) F. C. YarbrougH, City Inspector of IVeights and Measures, Charlotte, N. C.

\section{COMMITTEE ON WEIGHTS AND MEASURES EDUCATION}

J. T. Kennedr, Director, Department of Weights, Measures, and Markets, District of Columbia, Washington, D. C., Chairman. (4)

W. S. Busser, Assistant Chief, Office of Weights and Measures, National Bureau of Standards, Washington, D. C., Secretary. (6)

G. E. Carpexter, State Supervisor of Weights and Measures, Montpelier, Vt.

R. K. Slougr, City Sealer of Weights and Measures, Akron, Ohio. (3)

Robert Williams, County Sealer of Weights and Measures, Mineola, N. Y.

\section{COMMITTEE ON TRADING BY WEIGHT.}

J. F. TRue, State Sealer, Weights and Measures Division, Topeka, Kan., Chairman. (5)

J. E. Brenton, Chief, State Bureau of Weights and Measures, Sacramento, Calif. (1)

ErLing Hansen, Supervisor, State Department of Weights and Measures, Minneapolis, Minn. (3)

J. H. Mrer, Director, State Division of Markets, Richmond, Va.

H. K. THATCHER, Dilector, State Division of Agliculture and Industry, Little Rock, Ark.

\section{SPECIAL COMMITTEE ON UNIFORM REGULATIONS}

(To serve during the ensuing year and to report to the Thirty-Fifth National Conference. See page 166 of this report)

J. W. Recse, Superintendent, State Weiglits and Measures Division, Des Moines, Iowa, Chairman.

D. A. Fraser, County Sealer of Weights and Measures, Colchester, Conn.

C. I. Howr, Assistant Supervisor, State Department of Weights and Measures, Minneapolis, Minn.

R. D. Thompson, Supervisor, State Weights and Measures Section, Richmond, Va. E. C. Westwood, City Sealer of Weights and Measures, Salt Lake City, Utah.

\section{COMMITTEES ACTING ONLY DURING THE THIRTY-FOURTH NATIONAL CONFERENCE}

Committee on Nominations: ErLing HANsen of Minnesota, Chairman; V. D. Camprell of Ohio, C. M. Fulter of Los Aligeles Connty, Calif., A. H. Judkins of Salem, Mass., G. H. Leithauser of Baltimole, Md., J. G. Rogers of New Jersey, H. I. SHANKLE ot North Carolina.

Committee on Resolutions: J. E. BeEnton of California, Chairman; C. A. BaKer of New Jersey, J. M. Boucher of the District of Columbia, H. E. CrawFoRn of Jacksonville, Fla., J. M. DIETz of Union County, N. J., J. W. ReEse of Iowa, L. E. WrTT of Milwaukee, Wis.

In charge of press relations: J. G. DANCE of the District of Columbia.

In charge of Registrations: Mrs. R. E. Taylor, Miss P. T. WILliams, Mrs. K. M. SCHWARz. 


\section{PERSONS ATTENDING THE CONFERENCE}

\section{DELEGATES-STATE, CITY, AND COUNTY OFFICIALS}

\section{ALABAMA}

City : Birmingham

L. T. Wilcs, Chief Inspector, Bureau of Weights and Measures, 323 City Hall Building.

\section{CALIFORNIA}

State

JAmes F. Brenton, Chief, Bureau of Weights and Measures, Department of Agriculture, Mull

County : Building, Sacramento.

Alameda

Los Angeles

William A. Kerlin, Sealer of Weights and Measures, Court House, Oakland.

Charles Morris Fuller, Sealer of Weights and Measures, 3200 North Main Street, Los Angeles 31.

\section{COLORADO}

State

Jofrn E. Cronin, Director, Oil Inspection Department, 300 Logan Street, Denver.

\section{CONNECTICUT}

State

Frank M. Greene, Deputy Commissioner, Food and Drug Commission, 165 Capitol Avenue, Hartford.

City :

Hartford

Natuan Kalechman, Sealer of Weights and Measures, Municipal Building.

Norwich

Joseph E. Benac, Sealer of Weights and Measures, 24 Pratte Avenue, Taftville.

County :

Fairfield

William W. Sheehy, Sealer of Weights and Measures, County Court House, Bridgeport.

Hartford

Mino C. Griffin, Sealer of Weights and Measures, 95 Washington Street, Hartford 6.

Fred E. McKrynex, Deputy Sealer of Weights and Measures, 95 Washington Street, Hartford 6.

New London

Donald A. Fraser, Sealer of Weights and Measures, R. F. D., Colchester.

Tolland

IVIlliam F. Masinda, Sealer of Weights and Measures, West Wellington.

\section{DISTRICT OF COLUMBIA}

District

J. Thomas Kenneny, Director, Department of Weights, Measures, and Markets, 300 Indiana Avenue NW., Washington.

James G. Dance, Deputy Director, Department of Weights, Measures, and Markets, 300 Indiana Avenue NW., Washington.

JoHN M. Boucher, Supervisor, Department of Weights, Measures, and Markets, 300 Indiana Avenue NW., Washington.

Fenton C. HARBour, Inspector and Investigator, Department of Weights, Measures, and Markets, 300 Indiana Arenue NW., Washington.

William H. Jennings, Inspector and Investigator, Department of Weights, Measures, and Markets, 300 Indiana Avenue NW., Washington.

JoFn W. MURDock, Inspector and Investigator, Department of Weights, Measures, and Markets, 300 Indiana Avenue NW., IVashington. 
District-Continued

City :

Jacksonville

Miami
George Stuart Refder, Senior Inspector and Inrestigator, Department of Weights, Measures, and Markets, 300 Indiana Avenue NW., Washington.

WALTER W. BRANDT, Inspector, Department of Weights, Measures, and Markets, 300 Indiana Arenue NIV., Washington.

William Thomas Brunson, Inspector, Department of Weights, Measures, and Markets, 300 Indiana Arenue NW., Washington.

Walter R. Cornelius, Inspector, Department of Weights, Measures, and Markets, 300 Indiana Avenue NIV., Washington.

THEoDore B. Mirddeten, Inspector, Department of Weights, Measures, and Markets, 300 Indiana Avenue NIV., Washington.

RAIPH H. MoNTGOMERY, Inspector, Department of Weights, Measures, and Markets, 300 Indiana Avenue NW., Washington.

BernaRd A. PETTit, Inspector, Department of Weights, Measures, and Markets, 300 Indiana Avenue NW., Washington.

Francis M. WARNER, Inspector, Department of Weights, Measures, and Markets, 300 Indiana Avenue NW., Washington.

Wooprow W. 'WeILs, Inspector, Department of Weights, Mieasures, and Markets, 300 Indiana Arenue NW., Washington.

\section{FLORIDA}

Nalls Berryman, Supervisor, Weights and Measures Division, Department of Agriculture, Nathan Mayo Building, Tallahassee.

Howard E. Crawford, Inspector of Weights and Measures, Utilities Building.

HARVEY E. HowarD, Inspector of Weights and Measures, 321 Court House.

\section{IDAHO}

State-

L. A. Thompsox, Director, Division of Weights and Measures, Department of Agriculture, State House, Boise.

\section{ILLINOIS}

State-

Jонм J. Levitт, Superintendent of Standards, Department of Agriculture, Armory Building, springfield.

City :

Chicago

Invine M. Levr, Sealer of Weights and Measures, Room 608, City Hall.

Frank J. Fitzgerald, Chief Deputy Inspector of Weights and Measures, Room 608, City Hall.

Johis W. Callahan, Deputy Inspector of Weights and Measures, Room 608, City Hall.

Rockford

ERIcK J. Eck, Sealer of Weights and Measures, City Hall.

\section{INDIANA}

State-

Rolrin E. MEex, Director, Division of Weights and Measures, Department of Health, 102, North Senate Street, Indianapolis. 
City :

Fort Wayne

Gary

Indianapolis

County:

Saint Joseph

Vigo

State-

City : Louisville

State

Clty . Louistille--

State

Allen F. Chappuis, Director, Division of Weights and Measures, Department of Agriculture and Immigration, State Capitol Building, Baton Rouge.

\section{MAINE}

State

City :

Portland

Waterville

James A. Boyle, Deputy State Sealer, Bureau of Weights and Measures, Department of Agriculture, State House, Augusta.

Charles James Wills, Jr., Sealer of Weights and Measures, 389 Congress Street.

William A. Jones, Sealer of Weights and Measures, City Hall.

\section{MARYLAND}

City: Baltimore

George H. Leitinauser, Senior Assistant Superintendent of Weights and Measures, 1106 Municipal Building.

JoHn F. Brown, Inspector of Weights and Measures, 1106 Municipal Building.

CharLes G. Crockett, Inspector of Weights and Measures, 1106 Municipal Building.

Jomn R. Graefr, Inspector of Weights and Measures, 1106 Municipal Building. 
City: Baltimore_.......... EDWIN EDWARD JAFFA, Inspector of Weights and Measures, 1106 Municipal Building.

Miltox S. Krause, Inspector of Weights and Measures, 1106 Municipal Building.

Joseri H. Moss, Inspector of Weights and Measures, 1106 Municipal Building.

Fred J. O'Gordran, Inspector of Weights and Measures, 1106 Municipal Building.

Elarer S. Pierpont, Inspector of Weights and Measures, 1106 Municipal Building.

Henry C. SuITzER, Inspector of Weights and Measures, 1106 Municipal Building.

Hexry J. Slitzer, Inspector of Weights and Measures, 1106 Municipal Building.

County: Baltimore

Christian G. LIN K, Chief Inspector of Weights and Measures, Offutt Building, Towson 4.

GEonge A. KLeIN, Inspector of Weights and Measures, Offutt Building, Towson 4.

\section{MASSACHUSETTS}

State

John P. McBride, Director of Standards and Necessaries of Life, Department of Labor and Industries, 194 State House, Boston.

City :

Cambridge

Josepr M. O'NeIL, Sealer of Weights and Measures, Municipal Building.

Haverhill

JoHN R. Bоoтн, Sealer of Weights and Measures, Court Street.

Newton.

Andrew Prior, Sealer of Weights and Measures, City Hall.

Salem

LDward H. Junkins, Sealer of Weights and Measures, 174 Bridge street.

\section{MICHIGAN}

State

Wirliaxi W. Bough ner, Supervisor, Division of Weights and Measures, Department of Agriculture, 725 State Building, Lansing.

City :

Dearborn

Mitchell O. Nicton, Sealer of Weights and Measures, 4731 Korte Street.

Detroit

George F. Austin, JR., Deputy Sealer of Weights and Measures, 740 Elmwood Avenue.

William B. HEaslip, Supervising Inspector of Weights and Measures, 740 Elmwood Avenue.

Grand Rapids

Otтo F. Skodsholm, Sealer of Weights and Measures, 301 Market Street SW.

Hamtramck

Frank R. Szablewsiri, Sealer of Weights and Measures, 2963 Dan Avenue.

Lansing

Willard P. Barnes, Market Master and Sealer of Weights and Measures, 333 North Cedar Street.

Pontiac

Walter A. Baerwolf, Sealer of Weights and Measures, Police Department.

\section{MINNESOTA}

State

Erling Hansen, Supervisor, Department of Weights and Measures, Railroad and Warehouse Commission, 216 Corn Fxchange, Minneapolis.

Carl I. Hoel, Assistant Supervisor, Department of Weights and Measures, Railroad and Warehouse Commission, 216 Corn Exchange, Minneapolis.

City : Minneapolis

Russell S. Ackerman, Superintendent, Department of Licenses, Weights, and Measures, Room 3, City Hall. 


\section{MISSOURI}

City : St. Louis

City: Omaha

State

City :

Bayonne

Hoboken

North Bergen

Paterson

Union City

County:

Bergen

Camden

Cape May

Cumberland

Gloucester

Mercer

Monmouth

Morris

Passaic

Union
Joskph A. Bernard, Commissioner of Weights and Measures, 12 City Hall.

\section{NEBRASKA}

W. W. Gray, Chief Inspector of Weights and Measures, Room 100, City Hall.

\section{NEW JERSEY}

Josepir G. Rogers, Deputy Superintendent, Division of Weights and Measures, Department of Law and Public Safety, 187 West Hanover Street, Trenton 7.

Archie T. Smiti, Assistant Superintendent, Division of Weights and Measures, Department of Law and Public Safety, 187 West Hanover Street, Trelnton 7.

Samuel H. Christie, Jr., Senior Inspector, Division of Weights and Measures, Department of Law and Public Safety, 187 West Hanover Street; Trenton 7 .

Walter J. Flynd, Superintendent of Weights and Measures, 469 Boulevard.

Cirarles P. Romano, Superintendent of Weights and Measures, City Hall.

Arthur Sulcivan, Superintendent of Weights and Measures, Town Hall.

Joseph P. Leonard, Superintendent of Weights and Measures, 115 Van Houten Street:

William J. KeHoE, Assistant Superintendent of Weights and Measures, 115 Van Houten Street. Alfred O. Oscund, Superintendent of Weights and Measures, 3715 Palisade Avenue.

Ernest Edwin Dawson, Assistant Superintendent of Weights and Measures, 66 Zabriskie Street, Hackensack.

Michael J'. Santimauro, Assistant Superintendent of Weights and Measures, 66 Zabriskie Street, Hackensack.

Albert C. Becker, Superintendent of Weights and Measures, City Hall, Camden.

Gildert S. SMitr, Superintendent of Weights and Measures, 183 Twelfth Street, Avalon.

AcFred Linio, Superintendent of Weights and Measures, Court House, Bridgeton.

Winfield K. Tirompson, Assistant Superintendent of Weights and Measures, Court House, Bridgeton.

Martin J. Caulfield, Superintendent of Weights and Measures, Almonesson.

RALPH M. BodeNweiser, Superintendent of Weights and Measures, Court House, Trenton.

GleNe L. Berix, Superintendent of Weights and Measures, 706 Eighth Avenue, Asbury Park.

JoHN SAcco, Assistant Superintendent of Weights and Measures, Box 313, Long Branch.

Des G. Nerson, Superintendent of Weights and Measures, Court House, Morristown.

William Miller, Superintendent of Weights and Measures, Administration Building, Paterson.

JAMES M. Dretz, Superintendent of Weights and Measures, Court House, Elizabeth. 


\section{NEW YORK}

State

Erwin Y. Moore, Assistant Commissioner, Department of Agriculture and Markets, State Office Building, Albany.

Clement A. Baker, Director, Bureau of Weights and Measures, Department of Agriculture and Markets, State Office Building, Albany.

MatThew G. Rice, Inspector, Bureal of Weights and Measures, Department of Agriculture and Markets, \& Marlette Place, White Plains.

City :

Binghamton

Lovis E. REED, Sealer of Weights and Measures, City Hall.

Rochester

ANTHONY C. SAMENFink, Sealer of Weights and Measures, Public Market.

Counts :

Broome

Marry A. Lason, Sealer of Weights and Measures, 53 Bereir Street, Binghamton.

Monroe

Fred J. Young, Sealer of Weights and Measures, Room B, 1400 South Avenue, Rochester.

Nassau

Robert Williams, Sealer of Weights and Measures, Old County Court House Annex, Mineola.

William Kirk, Jr., Assistant Sealer of Weights and Measures, Old County Court House Annex, Mineola.

Niagara

Hexry C. Hulshoff, Sealer of Weights and Measures, 17 High Street, Lockport.

Oswego

Leland M. Flower, Sealer of Weights and Meas-

Suffolk ures, Lycoming.

Harwood G. EhrHand, Sealer of Weights and Measures, 211 Griffing Avenue, Ricerhead.

\section{NORTH CAROLINA}

State

C. D. BAUcos, Superintendent of Weights and Measures, Department of Agriculture, 415 Agriculture Building, Raleigh.

Herbert L. Shankie, Chief, Gas and Oil Inspection Division, Department of Revenue, Box 1510, Raleigh.

Cits : Charlotte

Fred C. IArbrough, Inspector of Weights and Measures, 2100 Brandon Circle.

\section{NORTH DAKOTA}

State

A. J. JENSEN, Chief Inspector of Weights and Measures, Public Service Commission, Jamestown.

\section{OHIO}

State

V. D. Camprell, Deputy State Sealer, Department of Agriculture, 710 State Office Building, Columbus.

Thomas M. Collins, Deputy State Sealer, Department of Agriculture, 710 State Office Building, Columbus.

City : Akron

Rosert K. Stovgh, Sealer of Weights and Measures,

County : 102 Iunicipal Building.

Hamilton

ANdrew C. DotzaUer, Deputy Sealer of Weights and Measures, Court House, Cincinnati.

Medina

Robert W. Searles, Deputy Sealer of Weights and Measures, Court House, Medina.

Summit

LE RoY WOLFord, Sealer of Weights and Measures, Court House, Akron. 


\section{OKLAHOMA}

State

R. Louie Ftanagan, Supervisol of Weights and Measures, Division of Markets, Board of Agriculture, 122 Capitol Building, Oklahoma City.

\section{PENNSYLVANIA}

State

JosepH F. Blrckley, Director, Bureau of Standard Weights and Measures, Department of Internal Affairs, Capitol Building, Harrisburg.

Spencer H. Seighman, Assistant Director, Bureau of Standard Weights and Measures, Department of Internal Affairs, Capitol Building, Harrisburg.

Harry E. Siromper, Senior Inspector, Bureau of Standard Weights and Measures, Department of Internal Afiairs, Capitol Building, Harrisburg.

County :

Clarion

Erie

Luzerne

City : Cranston

State

City :

Dallas

Houston.

City : Salt Lake City

E. C. Westrwoon, Sealer of Weights and Measures, 118 East First South.

\section{VIRGINIA}

State

J. H. MeEK, Director, Division of Markets, Department of Agriculture and Immigration, 1030 State Office Building, Richmond.

R. D. Thompson, Supervisor, Weights and Measures Section, Division of Markets, Department of Agriculture and Immigration, 1030 State Office Building, Richmond.

Thomas C. Harris, Inspector, Weights and Measures Section, Division of Markets, Department of Agriculture and Immigration, 1030 State Office Building, Richmond.

I. C. Sturais, Inspector, Weights and Measures Section, Division of Markets, Department of Agriculture and Immigration, Davis Wharf. 
City :

Newport News

Norfolk

Richmond

John Boyd LaYton, Sealer of Weights and Measures, Box 384.

Webster K. Tripple, Chief, Bureau of Weights and Measures, City Market Building.

Conway C. Mundy, Chief, Bureau of Weights and Measures, The Mosque Building, Laurel and Main Streets.

JoHn J. Anderson, Inspector, Bureau of Weights and Measures, The Mosque Building, Laurel and Main Streets.

Jorr N. WhrTLow, Inspector, Bureau of Weights and Measures, The Mosque Building, Laurel and Main Streets.

\section{WASHINGTON}

City : Seattle

Walter L. Dantels, Director, Division of Licenses and Standards, Room 100, County-City Building.

Llewellyn R. ROPER, Supervisor, Division of Licenses and Standards, Room 100, County-City Building.

\section{WISCONSIN}

State

George W. WARner, Supervisor, Weights and Measures Inspection, Department of Agriculture, Capitol Building, Madison.

City :

Milwaukee

Louis E. Witt, Sealer of Weights and Measures, 1331 North Fifth Street.

Racine

Robert "Zirkten, Sealer of Weights and Measures, City Hall.

Sheboygan

Joseph A. Peikert, Sealer of Weights and Measures, City Hall.

Superior

Oscar E. Roeseler, Sealer of Weights and Measures, City Hall.

West Allis

Artuur E. La Boda, Sealer of Weights and Measures, City Hall.

\section{WYOMING}

State

Charles H. OAKLEY, State Inspector of Weights and Measures, 310 Capitol Building, Cheyenne.

\section{DELEGATES-NATIONAL BUREAU OF STANDARDS}

DireCtor's OfFICE :

E. .U. Condon, Director.

LYMAN J. BRIGGS, Director Emeritus.

E. C. Crittenden, Associate Director.

R. W. Sмiтh, Chief, Office of Weights and Measures.

William S. Bussey, Assistant Chief, Office of Weights and Measures.

Robert J. Neale, Office of Weights and Measures.

Meteorology Division:

Wilmer Souder, Chief.

Herbert L. Badger, Scale Section.

H. S. Bean, Chief, Capacity, Density, and Fluid Meters Section.

Eleanor M. Clinton, Mass Section.

RalpH E. Gould, Chief, Time Section.

Lewrs V. Judsox, Chief, Length Section.

Lloyp P. Macurdy, Chief, Mass Section.

H. Haig Russeld, Chief, Scale Section.

Commodity Standards Division:

W. E. Brafth waIte, Chief, Packaging Section. 


\section{GUESTS REPRESENTING UNITED STATES GOVERNMENT}

U. S. Department of Agriculture:

CHARLES L. RICHARD, Supervisor of Scales and Weighing, Livestock Branch, Room 3520, South Building, Washington 25, D. C.

Federal Security Agency :

John L. Harvey, Director of Litigation, Food and Drug Administration, Washington $25, \mathrm{D} . \mathrm{C}$.

William A. Queen, Chief, Division of State Cooperation, Food and Drug Administration, Washington 25, D. C.

National Military Establishment:

Frank J. Rawson, Standards Engineer, Office of the Secretary of Defense, Washington $25, \mathrm{D}$. C.

Post Office Department:

Jesse C. Miller, Slrilled Draftsman, Division of Equipment and Supplies, Washington $25, \mathrm{D}$. C.

Treasury Department:

FrED W. Gast, Chief, Division of Engineering and Weighing, Bureau of Customs, Washington 25, D. C.

\section{GUESTS REPRESENTING MANUFACTURERS OF WEIGHTS AND MEASURING DEVICES}

All Weather Springs: John IV. Rockefeller, Engineer, 140 Cedar Street, New York 6, N. Y.

Bloomer Brothers Co.: Raynor M. Holmes, Research Engineer, Newark, N. Y. Bowser, Inc.: Clement P. Griffith, Vice President, Fort Wayne, Ind.

Brodie, Ralph N., Co., Inc.:

C. J. MCCAFFrey, Vice President, 550 South Columbus Avenue, Mount Vernon, N. $Y$.

Don W. Kingstey, 550 South Columbus Avenue, Mount Vernon, N. X.

Chatillon, John, \& Sons :

J. George Hugel, Sr., Sales Representative, 85 Cliff Street, New York, N. Y.

John F. Iiose, Manager, Spring Division, 85 Cliff Street, New York, N. Y.

Cox \& Sterens Aircraft Corp.: George E. Flanagan, Production Manager, P. O. Box 30, Mineola, N. Y.

Detecto Scales, Inc.:

MACK RapP, Vice President, 540 Park Avenue, Brooklyn 5, N. Y.

Harold J. Fuller, Zone Manager, 1404 West Third Avenue, Columbus, Ohio.

Mrs. Carrie G. Woodland, Representative, Fellsmere, Fla.

Dixie Cup Co.: Arthur J. Nolan, Assistant to the President, 421 North Western $\Delta$ venue, Chicago, Ill.

Durham Scale Co.: William G. Emmons, Owner, Ellis Road, Route 4, Durham, N. C.

Exact Weight Scale Co.:

Kinzie B. NeFr, President, 944 West Fifth Avenue, Columbus, Ohio.

James F. Sullivan, Engineer. 944 West Fifth Arenue, Columbus, Ohio.

Ex-Cell-O Corporation: WALT E. DisNeY, Sales Engineer, 1200 Oakman Boulevard, Detroit, Mich.

Fair S'cale Co.: Albert A. Veth, President, 1142 Logan Street, Louisville, Ky.

Fairbanks, Morse \& Co.:

Leonard J. Maguire, Chief Engineer, St. Johnsbury, Vt.

Wrllia M D. Clark, Manager Scale Department, 600 South Michigan Avenue, Chicago, Ill.

W. N'. Copeland, 1427 I Street NW., Washington 5, D. C.

William C. GaNTt, Scale Selvice Manager, 2010 Lovegrove Street, Baltimore $18, \mathrm{Md}$.

C. A. Hennie, Field Engineer, 2010 Lovegrove Street, Baltimore 18, Md.

Jerome KenNeY, Field Engineer, 80 Broad Street, New York 4, N. Y.

NeIL C. Wells, Engineer, 600 South Michigan Avenue, Chicago, Ill.

Forschner, R. H., Co.: Richand A. Forsch ner, General Manager, 205 Third Avenue, New York 3, N. Y.

Gilbert \& Barker Manufacturing Co.:

Joseph A. Logan, West Springfield, Mass.

C. A. P. Thomas, West Springfield, Mass.

Gurley, W. \& L. E.: Franklin G. Williams, Washington Representative, 5514 Nevada Avenue NW., Washington 15, D. C. 
Hobart Manufacturing Co.:

Burns H. Dreese, General Manager, Troy, Ohio.

Ernest A. ReussenzeHn, Chief Scale Engineer, Scale Division, 444 Hoffman Avenue, Dayton, Ohio.

Murray W. Cratg, Sales Department, Troy, Ohio.

Howe Scale Co.:

Rrchamd F. Straw, Vice President, Rutland, Vt.

Robert A. Parham, Branch Manager, 309 East Saratoga Street, Baltimore, $\mathrm{Md}$.

LaCY A. SPaKe, 1338 East Fourth Street, Charlotte, N. C.

Lily-Tulip Cup Corporation :

Robert H. McKenna, Vice President, 122 East Forty-second Street, New Yark $17, \mathrm{~N}$. $\mathrm{Y}$.

Rrchard S.' Wechsier, Counsel, 122 East Forty-second Street, New York 17, N.' Y.

Lincoln Engineering Co.: BeN S. Davis, Division Manager, St. Louis, Mo.

Martin \& Schwartz, Inc., JACK H. Prause, Assistant General Manager, Mill Street, Salisbury, Md.

National Store Specialty Co.: Wallace E. Sheaffer, President, Bareville, Pa. Neptune Meter Co.:

Charles S. Hazard, Director of Research, 192 Jackson Avenue, Long Island City, N. Y.

Walter H. Sieger, Engineer, 50 West Fiftieth Street, New York, N. Y.

Owens-Illinois Glass Co.: J. J. Moran, Customer Research Department, Vineland, N. J.

Par-Tee Co.: Paul F. Partee, President, Spencerville, Ind.

Peerless Weighing \& Vending Machine Corporation:

James J. Crosby, Vice President, 29-28 Forty-first Avenue, Long Island City, N. $Y$.

Leverett D. Chambers, 29-28 Forty-first Avenue, Long Island City, N. Y.

Penn Scale Co.: B. William Felgorse, Sales Manager, 150 West Berks Street, Philadelphia, Pa.

Rockwell Manufacturing Co.:

H. D. Lersenning, Sales Manager, Pittsburgh Equitable Meter Division, 400 North Lexington Avenue, Pittsburgh, Pa.

Edward R. Eyler, Sales Engineer, Pittsburgh Equitable Meter Division, 600 Grant Street, Pittsburgh 19, Pa.

Sanitary Scale Co.: Edward C. Karp, Plant Manager \& Chief Engineer, Belvidere, IIl.

Seederer-Kohlbusch, Inc.: Jасов E. Seederer, President, Englewood, N. J.

Seraphin Test Measure Co.: 'T. A. Seraphin, President, 1314 North Serenth Street, Philadelphia, Pa.

Service Station Equipment Co.:

W. M. Hoxre, Service Manager, Muskegon, Mich,

Louis G. Close, Division Manager, Mid Atlantic States, 2127 North Charles Street, Baltimore 18, Md.

Stimpson Computing Scale Co.: Frank M. Doyne, Eastern General Distributor, 468 Weaver Street, Larchmont, N. Y.

Streeter-Amet Co.: Verne C. Kennedy, President, 4101 North Ravenswood Avenue, Chicago, Ill.

Thatcher Glass Manufacturing Co.: James Arrandale, Director of Quality Control, Elmira, N. Y.

Tokheim Oil Tank \& Pump Co.: William E. Loutran, Service Manager, 1600 Wabash Avenue, Fort Wayne, Ind.

Toledo Scale Co.:

Stanley Q. Bennett, General Manager of Service, Toledo, Ohio.

Warren H. Hem, Chief Development Engineer, Toledo, Ohio.

M. E. Rose, Government Representative, 3713 New Hampshire Avenue NW., Washington, D. C.

Edwin C. Smrth, 305 East Sixty-third Street, New York, N. X.

Walter G. Williams, District Manager, 3713 New Hampshire Avenue NW., Washington, D. C.

Patrick Ldward Young, District Manager, Box 2107, Raleigh, N. C.

Torsion Balance Co.: RAYmond G. Nordstrom, Manager, Market Development, Clifton, N. J. 
Triner Scale \& Manufacturing Co.:

John E. Edgerton, Representative, 1395 National Press Building, Washington, D. C.

Frank A. Lang, Representative, 2714 West Twenty-first Street, Chicago 8, III.

'Troemner, Henry :

Cinarles F. Rosica, Sales Manager, 911 Arch Street, Philadelphia, Pa.

Lours KIesel, Representative, 911 Arch Street, Philadelphia, Pa.

U. S. Slicing Machine Co.:

Byron D. Miller, Zone Manager. Standard Computing Scale Division, 9 Bogert Place, Bronxville 8, N. Y.

Matt D. Ribrle, Special Representative, Standard Computing Scale Division, La Porte, Ind.

Veeder-Root. Inc. : Austin E. McKecver, Sales Representative, 70 Sargeant Street, Hartford, Conn.

Watling Manufacturing Co.: Marvin E. Maddox, Sales Manager, 4650 West Fulton. Street, Chicago, Ill.

Wasne Pump Co.:

T. Jоп Uníma, Chief Engineer, Ft. Wayne, Ind.

Herman M. Rost, Selvice Engineer, Ft. Wayne, Ind.

Yale and Towne Manufacturing Co.:

James D. Young, Manager, Scale Section, Philadelphia Division, Roosevelt Boulevard, Philadelphia 15, Pa.

Joseph J. Murray, Service Manager, Philadelphia Division, Roosevelt Boulevard, Philadelphia 15, Pa.

\section{GUESTS REPRESENTING ASSOCIATIONS, BUSINESS AND INDUSTRY, AND RAILROADS}

American Petroleum Institute:

J Ames E. Moss. Director, Division of Transportation, $1625 \mathbf{K}$ Street NW., Washington, D. C.

Gavin W. Laurie, Chairman, Central Committee on Automotive Transportation, The Atlantic Refining Co., 260 South Broad Street, Philadelphia 1, Pa.

Anıerican Seed Trade Association: William Heckendors, Executive Secletary, 30 North La Salle, Chicago, Ill.

Association of American Soap and Glycerine Producers, Inc.: RoY W. PEET, Manager, 295 Madison Avenue, New York, N. Y.

Baltimore \& Ohio Railroad Co.: E. Kent Lawrence, General Scale Inspector, Baltimore 1, Md.

Betlilehem Steel Co.: Gwilrm E. Evans, Scale Repair Foreman, Sparrows Point, Md.

Carnegie Illinois Steel Corporation; Charles Bauer, Scale Shop Foreman, 328 West Ridge Road, Gary, Ind.

Chicago \& Northwestern Railroad: Harre Mayer. Supervisor, Scales and Work Equipment, 400 West Madison Street, Chicago, Ill.

Continental Can Co., Inc.: Johx C. Jennings, Manager, Mono Container Sales, 349 Oraton Street, Newark 4, N. J.

Dairy Industry Committee: Melvin II. Brightman, Executive Secretary, 1112 Bar"r Building, Washington, D. C.

Esso Standard Oil Co.: Logan L. Kennent, Superintendent, Construction and Maintemance, 500 North Broad Street, Elizabeth, N. J.

Fel'y, Morse Seed Co.: Gronge B. Smitr, Assistant Superintendent, P. O. Box 778. Detroit 31, Mich.

Gasoline Pump Manufacturers Association: G. Denny Moore, Managing Director, 420 Lexington Avenue, New York, N. Y.

Glass Container Manufacturer's Institute: Nicholas G. Cameron, 8 West Fortieth Street, New York. N. Y.

Goodyear Tire \& Rubber Co.: Jack T. Holloway, Representative, Akron, Ohio.

Gulf Oil Corporation: BerNard WAGNER, Engineer, Gulf Building, Pittsburgh 19, Pa.

Industrial Research Syndicate : C. A. Lindsay, Director, 1305 Euclid Street NIV., Washington 9, D. C.

Inland Steel Co.: Harry M. Roeser, Supervisor of Scales, East Chicago, Ill. 
Liquefied Petroleum Gas Association: Walter H. Hoagland, 11 West Fortysecond Street, New York, N. Y.

Liquid Tight Paper Container Association: Arthur W. Howe, Jr., Assistant Executive Secretary, 1532 Lincoln Liberty Building, Philadelphia, Pa.

Miller's' National Federation:

Herman Fakler, President, S47 National Press Building, Washington, D. C. Albert H. Krueger, S47 National Press Building, Washington, D. C.

National Association of Scale Manufacturers:

L. H. Erickson, President, 469 East Ohio Street, Chicago, Ill.

Artmur Sanders, Secretary, 1129 Vermont Avenue NIV., Washington. D. C.

Paper Cup and Container Institute, Inc. : Dale H. Eckerman, Executive Director, 1790 Broadway, New York 19, N. Y.

Pennsylvania Railroad: MI. J. J. Harrison, Supervisor of Scales and Weighing, Box 345, Altoona, Pa.

Pillsbury Mills, Inc. : Bradshaw Mintener, Vice President and General Counsel, 600 Pillsbury Building, Minneapolis 2, Minn.

Procter \& Gamble Co.: William G. Werner, Director, Public Relations, Cincinnati, Ohio.

Saybolt, E. W. \& Co.: Hamiond C. Sprndell, 265 Bayway, Elizabeth, N. J.

Shell Oil Co. :

C. H. Betrel, Supervisor of Operations, East Rutherford, N. J.

Louis A. Thommen, Division Engineer, 3706 Eighty-second Street, Jackson Heights, N. Y.

Thread Institute, Inc. :

David SNyder, Executive Director, 11 West Forty-second Street, New York, N. Y.

Jorn BELl, Chairman, Legislation Committee, 11 West Forty-second Street, New York, N. Y.

Tissue Association, Inc.: Douglas A. Crocker, Assistant Secretary, 122 East Forty-second Street, New York, N. Y.

\section{MISCELLANEOUS GUESTS}

Alex Piscrotta, Magistrate, 419 Stockholm Street, Brooklyn, N. Y. Ho SrK Yr, Weights and Measures Station, Seoul, Korea. 



\section{CONTENTS}

Officers and Committees

III

Persons attending the Conference

FIRST SESSION-MORNING OF TUESDAY, MAY 24, 1949

Address by Dr. E. U. Condon, Director, National Bureau of Standards, and President, National Conference on Weights and Measures............. Standardization of Membership on Standing National Conference Committees, and Number of National Conference Vice Presidents and Executive Committeemen Appointments to Standing Committees

Abstracts of State Reports:

California, by James E. Brenton, Chief, State Bureau of Weights and

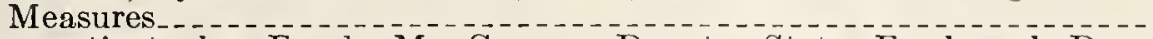

Connecticut, by Frank M. Greene, Deputy State Food and Drug Commissioner

District of Columbia, by Ralph A. Montgomery, Inspector of Weights and Measures_._.

Florida, by Nalls Berryman, Supervisor, State Division of Weights and

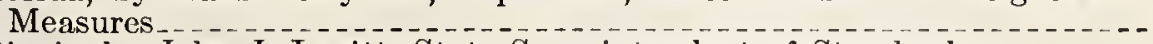

Illinois, by John J. Levitt, State Superintendent of Standards _......

Indiana, by Williams $\mathrm{H}$. Roberts, Inspector of Weights and Measures of Vigo County

Kansas, by J. Fred True, State Sealer of Weights and Measures.......

Kentucky, by George L. Johnson, Director, State Division of Weights and

Louisiana, by Allen F. Chappuis, Director, State Division of Weights and

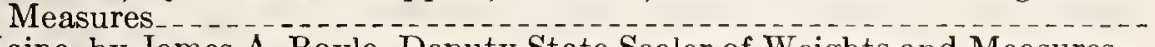

Maine, by James A. Boyle, Dcputy State Scaler of Weights and Measures.-

Massachusetts, by John P. McBride, State Director of Standards and Necessaries of Life

Michigan, by William W. Boughner, Supervisor, State Division of Weights and Measures _._._.

Minnesota, by Erling Hansen, Supervisor, State Department of Weights and Measures Missouri, by Joseph A. Bernard, Commissioner of Weights and Measures,

Nevada, by Wayne B. Adams, State Sealer of Weights and Measures...

New Jersey, by Joseph G. Rogers, Deputy Superintendent, State Division of Weights and Measures.

New York, by Clement A. Baker, Director, State Bureau of Weights and Measures.

North Carolina, by C. D. Baucom, State Superintendent of Weights and

Measures... Jensen, Chief State Inspector of Weights and
North Dakota, by A. J. Ju-

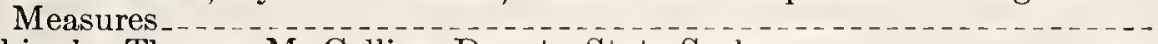

Ohio, by Thomas M. Collins, Deputy State Sealer
Oklahoma, by R. Louie Flanagan, State Supervisor of Weights and

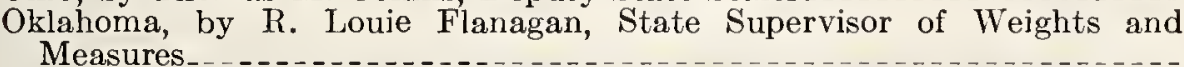
Pennsylvania, by Spencer H. Seighman, Assistant Director, State Bureau of Standard Weights and Measures

Rhode Island, by Edward R. Fisher, State Sealer of Weights and Measures

South Carolina, by Alex H. Gibert, Chief State Inspector of Weights and

Measures.
Texas, by James J. Donnelly, Chief, Weights and Measures Division, City of Houston . . . . . . . . . 
Abstracts of State Reports-Continued

Utah, by E. C. Westwood, Sealer of Weights and Measures of Salt Lake City -

Virginia, by R. D. Tlompson, Supervisor, State Weights an 1 Measures Section

Wisconsin, by George IV. Warner, Supervisor, State Weights and Measures Inspection

Wyoming, by Charles H. Oakley, State Inspeetor of Weights and Measures_

Abstraets of Reports of Representatives of State and Regional Assoeiations of Weights and Measures Offieials:

California Assoeiation of Weights and Measures Offieials, by William A. Kerlin, Sealer of Weignts and Measures of Alameda County, Calif .....

Conneetieut Sealers' Assoeiation, by Donald A. Fraser, Sealer of Weights and Measures of New London County, Conn

Illinois Weights and Measures Assoeiation, by John J. Levitt, State Superintendent of Standards

Indiana Assoeiation of Inspeetors of Weights and Measures, by C. C. Morgan, Sealer of Weights and Measures of Gary, Ind _...........

Massaehusetts Weights and Measures Assoeiation, by Edward H. Judkins, Sealer of Weights and Measures of Salem, Mass

Michigan Association of Weights and Measures Offieials, by William B. Heaslip, Supervising Inspeetor of Weights and Measures of Detroit, Mieh

New York State Weights and Measures Assoeiation, by Robert Williams, Sealer of Weights and Measures of Nassau County, N. Y._.........

Northwest Weights and Measures Assoeiation, by Carl I. Hoel, Assistant Supervisor, Minnesota State Department of Weights and Measures...

Ohio Sealers' Assoeiation, by Andrew C. Dotzauer, Deputy Sealer of Weights and Measures of Hamilton County, Ohio _..............

Pennsylvania Assoeiation of Inspeetors of Weights and Measures, by Gordon S. Watkins, Sealer of Weights and Measures of Luzerne County, $\mathrm{Pa}$

Southerm Weights and Measures Assoeiation, by C. D. Baueom, State Superintendent of Weights and Measures of North Carolina._._._......

Texas Weights and Measures Assoeiation, by Frank G. Yarbrough,

Deputy Sealer of Weights and Measures of Dallas, Texas
Virginia Weights and Measures Assoeiation, by Webster K. Tripple, Chief,

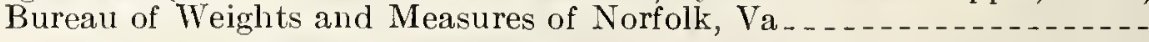

SECOND SESSION-AFTERNOON OF TUESDAY, MAY 24, 1949

Appointment of Working Committees, and Miseellaneous Announeements by the Seeretary.

Report of the National Conference Committee on Legislation, Presented by Rollin E. Meek, Chairman

Liquefied Petroleum Gas:

Units of Measurement, by J. F. Bliekley, Direetor, Bureau of Standard Weights and Measures, State of Pennsylvania

Problems Eneountered in Testing Metered Systems, by Charles Morris Fuller, Sealer of Weights and Measures, County of Los Angeles, Calif - -

Supervision Over Sales, by H. L. Shankle, Chief, Gasoline and Oil Inspection Division, State of North Carolina

Testing Equipment for Large-Capacity Meters, by Paul Renfrew, Chief Engineer, Ralph N. Brodie Co., Ine.

A Report From The National Scale Men's Assoeiation, by William D. Clark, Manager, Seale Department, Fairbanks-Morse and Co., and Past President, NSM A Open Forum

\section{THIRD SESSION-MORNING OF WEDNESDAY, MAY 25, 1949}

Testing Proeedures for Four-Seetion Seales, by H. H. Russell, Chief, Seetion on Seales, National Bureau of Standards.

Testing Proeedures for Livestoek Seales, by C. L. Riehard, Supervisor of Seales and Weighing, Livestoek Branch, U. S. Department of Agrieulture.

Mutual Public Relations Problems of Weights and Measures Offieials and Ameriean Agrieulture, by Dr. E. V. Moore, Assistant Commissioner, Department of Agriculture and Markets, State of New York.......... 
Announcements by the Secretary

Shrinkage on Packaged Wheat Products, by J. L. Harvey, Director of Litigation, Federal Food and Drug Administration

Stand-By Service of Testing Equipments During Repairs, by J. F. True, State Sealer, Weights and Measures Division, State of Kansas

Report of The National Conference Committee on Weights and Measures Education, Presented by J. T. Kennedy, Chairman

Tour of Bureau of Standards Laboratories

\section{FOURTH SESSION-MORNING OF THURSDAY, MAY 26, 1949}

Report of The National Conference Committee on Trading by Weight, Presented by J. H. Meek, Chairman
Calibration of Volumetric Standards, by H. S. Bean, Chief, Section on Capacity, Density, and Fluid Meters, National Bureau of Standards.-

Standardization of Report Forms, by R. D. Thompson, Supervisor, Weights and Measures Section, State of Virginia Quantity Declarations on Packaged Soap Products:

Remarks of J. A. Bernard, Commissioner of Weights and Measures, City of St. Louis, Mo

Remarks of R. W. Peet, Manager, Association of American Soap and Glycerine Producers, Inc.

Remarks of Mr. Alex Pisciotta, Former Director of the Bureau of Weights and Measures of New York City.

Uniformity of Interpretation and Enforcement, by L. E. Witt, Sealer of Weights and Measures, City of Milwaukee, Wis.

Reconsideration of Action Relative to the Number of Vice Presidents and Elected Committeemen

Impact on the Steel Business of Formal Specifications for Weighing Machinery, by H. M. Roeser, Supervisor of Scales, Inland Steel Co

FIFTH SESSION-AFTERNOON OF THURSDAY, MAY 26, 1949

Systematized Package Supervision, by I. M. Levy, Sealer of Weights and Measures, City of Chicago, Ill

Federal Aid in Weights and Measures programs:

Remarks of J. H. Meek, Director, Division of Markets, State of Virginia 105

Remarks of Dr. E. C. Crittenden, Associate Director, National Bureau

of Standards.
Remarks of Dr. Lyman J. Briggs, Former President of the National Con-
ference on Weights and Measures.

Report of the National Conference Committee on Methods of Sale of Commodities, Presented by J. G. Rogers, Chairman, and Discussion Thereon -

Testing Procedures for Vehicle-Tank Compartments:

Remarks of J. M. Dietz, Superintendent of Weights and Measures,

County of Union, N. J tation, A. P. I., Presented by G. W. Laurie, Chairman, Central Committee on Automotive Transportation _. _.....................

Care and Use of Primary State Standards:

Remarks of W. S. Bussey, Assistant Chief, Office of Weights and Measures, National Bureau of Standards Remarks of W. W. Boughner, Supervisor, Division of Weights and
Measures, State of Michigan,

\section{SIXTH SESSION-MORNING OF FRIDAY, MAY 27, 1949}

Commodity Tolerances, by R. K. Slough, Sealer of Weights and Measures, City of Akron, Ohio

Report of the National Conference Committee on Specifications and Toler-
ances, Presented by J. P. McBride, Chairman, and Discussion Thereon --

Introduction to the Tentative Report of the Committee on Specifications and Tolerances

Introduction to the Final Report of the Committee on Specifications

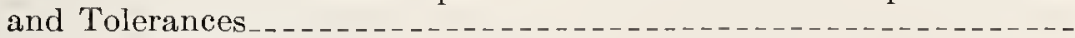

Section on General Code

Section on Fabric-Measuring Devices _..._. 
Report of the National Conferenee Committee on Specifications and Toleranees, ete.-Continued

Seetion on Graduates

Seetion on Lubrieating-Oil Bottles

Seetion on Liquid-Measuring Deviees $\ldots \ldots \ldots \ldots \ldots \ldots \ldots \ldots \ldots$

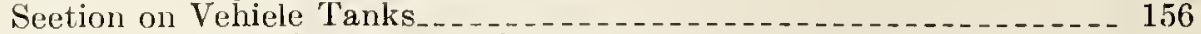

Seetion on Berry Baskets and Boxes

Seetion on Seales_._.

Adjustments by Weights and Measures Offieials, by C. H. Oakley, Inspeetor of Weights and Measures, State of Wyoming Report of the National Conferenee Committee on Resolutions, Presented by J. E. Brenton, Chairman:

Appreeiation to Direetor and Staff of the National Bureau of Standards_ 165

In Meinory of Deeeased Members

J. W. Saybolt $\ldots \ldots \ldots$

Appreeiation to the Press

Memorial Serviees

Special Committee on Uniform Regulations

Report of the National Conferenee Treasurer, George F. Austin, Jr

Report of the National Conferenee Committee on Nominations, Presented by Erling Hansen, Chairman, and Eleetion of Offieers _._.

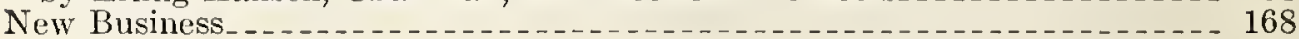




\title{
REPORT OF THE THIRTY-FOURTH NATIONAL CONFERENCE ON WEIGHTS AND MEASURES
}

\author{
SPONSORED BY THE NATIONAL BUREAU OF STANDARDS, AND HELD \\ AT THE WARDMAN PARK HOTEL, WASHINGTON, D. C., MAY 24, 25,
} 26, AND 27, 1949

\section{FIRST SESSION-MORNING OF TUESDAY, MAY 24, 1949}

(The Conference was called to order at 10:10 a.m. by E. U. Condon, President of the Conference.)

ADDRESS BY DR. E. U. CONDON, DIRECTOR, NATIONAL BUREAU OF STANDARDS, AND PRESIDENT, NATIONAL CONFERENCE ON WEIGHTS AND MEASURES

Welcome to the Thirty-fourth National Conference on Weights and Measures! We are meeting this week after an interval of about a year and a half, no meeting having been held during 1948 in consequence of decisions taken at the time of our last meeting that future meetings. should be held in the spring.

On this account there is a rather heavy accumulation of important business to come before us and therefore I will be brief. I am happy to note that the full schedule nevertheless permits tomorrow afternoon to be devoted to inspection of the laboratories of the National Bureau of Standards, an inspection which I hope you will find interesting and worth while.

Perhaps I should first report on some activities of the Bureau of Standards of direct interest to this body. As most of you know by now, Mr. W. S. Bussey, formerly chief of the State Division of Weights and Measures in Texas, joined the staff of the Bureau's Office of Weights and Measures last August. He and Mr. Ralph W. Smith, Chief of the Office of Weights and Measures and Secretary of this Conference, have been able to carry on a program of visits to the various State and local weights and measures offices and to take part in nearly all of the State and regional weights and measures conferences. I think this is contributing a great deal to close working relations between all of those who have responsibility for weights and measures work in all parts of the country and us in Washington who have the responsibility for maintenance of the basic standards and for research in improvement of measurement methods.

Another addition to the staff of the Office of Weights and Measures joined our staff only yesterday. He is Mr. Robert J. Neale, who comes to us after experience as the State weights and measures officer assigned to Yuba County, California. Older members of the Conference will be interested to know that he is a grandson of Charles C. Neale, former Commissioner of Weights and Measures of the State of 
Minnesota, and a long-time member of this Conference. He will be assigned to work in the laboratories of the Metrology Division of the Bureau where he will give special attention to the testing work required by State and local weights and measures officers.

You will be interested to know that rapid progress is being made on a completely new Bureau publication presenting a compilation of Federal and State Laws on Weights and Measures. It is expected that the manuscript will go to the printer soon after the first of next year. It should be available for sale by the Superintendent of Documents by about July 1950. The size of this important book is such that it will cost several dollars a copy although there will be free distribution of one copy to each State weights and measures office.

Your Committee on Specifications and Tolerances has been hard at work on a new Handbook to replace the time-lonored Handbook H29 and will present its report to this Conference on Friday. If the report as presented meets with your approval at that time, the manuscript will be sent to the printer and the new books will probably be available in about 3 months. It is to be designated as $\mathrm{H} 44$.

It is gratifying to note that several States have taken steps to improve the laws governing their weights and measures work. Since our last meeting the State of Louisiana has enacted a weights and measures law, and has organized and in operation a new Division of Weights and Measures in its Department of Agriculture and Immigration.

A major strengthening of the weights and measures statutes of Towa was accomplished by a bill which was enacted this year. In Oklahoma a bill to extend the weights and measures authority of the State Board of Agriculture and to provide for a systematic program of supervision throughout the State has been passed by both houses of the Legislature, and it is expected that it will be signed by the Govcrnor. Originally patterned upon the Model State Law, this bill was amended in several important respects by the Legislature and now contains some provisions which are at variance with Model-Law principles.

Serious consideration has been given by the legislature of Delaware to the enactment of a weights and measures bill based on the Model Law and designed to create an active State Division of Weights and Measures; the latest information at hand is that passage of this bill is being delayed by the prolonged consideration of primary appropriations measures, and by the fact that the weights and measures bill provides for an appropriation to make it effective.

Kentucky has indicated the probability that a weights and measures bill will be presented to the legislature at its next session, in 1950 , and in Mississippi efforts to obtain enactment of a comprehensive weights and measures law are being continued. Both Arkansas and New Mexico are interested in similar legislation, and it is hoped that weights and measures bills will be presented to the legislatures of those States in 1951.

Many States and numerous local jurisdictions have made notable additions to their testing equipment and more such improvements are in process. This new equipment is to be found particularly in large scale-testing units and in large-denomination volumetric standards for the testing of meters and vehicle-tank compartments. 
There have been a number of clianges in personnel among the State weights and measures offices. In Idaho Mr. L. A. Thompson is now Chief Inspector of the State Division of Weights and Measures in the Department of Agriculture. There has been a change of administration in Illinois, and Mr. Paddock has been succeeded as State Superintendent of Standards by Mr. J. J. Levitt, a former incumbent of this office. Mr. George L. Johnson has succeeded Mr. J. E. Johnston as Director of the State Division of Weights and Measures of Kentucky. Mr. A. F. Chappuis is Director of the new Louisiana State Division of Weights and Measures. Mr. James A. Boyle, formerly City Sealer of Portland, Maine, has become the Deputy State Sealer of Weights and Measures of Maine, filling the vacancy created by the resignation of Mr. Heath. In Missouri the Director of the Weights and Measures Division in the State Department of Agriculture is now Mr. Rollo E. Singleton. The new Commissioner of Agriculture, Labor, and Industry of Montana, in charge of weights and measures in that State, is Mr. A. R. Anderson. We were saddened a few days ago to learn of the sudden death, on May 11, of Mr. Joseph Giuliano, Superintendent of the State Division of Weights and Measures of New Jersey. In North Carolina the Gasoline and Oil Inspection Division is being transferred from the Department of Revenue to the Department of Agriculture, but it is assumed that Mr. H. L. Shankle will continue as Division Chief. Weights and Measures supervision in Oklahoma has been placed in the Division of Markets of the State Board of Agriculture, of which Mr. Fain G. Cesar is the Director. Mr. C. R. Jester is now the Deputy State Sealer of Weights and Measures of Oregon. Mr. Anton Prestwick has succeeded Mr. Scliock as Director of the Division of Inspections of the South Dakota Department of Agriculture. Mr. Matt Jennings, Director of the Tennessee Division of Markets in the Department of Agriculture, now has charge of weights and measures in that State. In Texas Mr. Bussey was succeeded as Chief of the State Division of Weights and Measures by Mr. Phil Ford, with Mr. F. J. Heironomus continning as assistant. In the State of Washington Mr. T. A. Carter has succeeded Mr. Palmer as State Supervisor of Weights and Measures in the Department of Agriculture.

The Secretary advises me that we have representation at the Conference this year from a number of States not formerly represented or not represented for a considerable period. This is very gratifying, and probably stems from an increasing degree of interest in weights and measures supervision. I hope that all new delegates to the Conference, representing either State or local jurisdictions, will take full advantage of the opportunity of getting acquainted with their associates from other parts of the country. The resulting exchange of ideas can be one of the most helpful things a delegate gets out of attendance at a National Conference.

Turning now more specifically to Conference affairs let me recall that at the Thirty-third National Conference, held in $194 \%$, both the Committee on Resolutions and the Committee on Nominations held meetings to which members of the Conference were invited for the purpose of making suggestions relative to resolutions and to nominees for office. I think it was a good idea and I hope that it will be done again at this and future Conferences. The Committee on Nominations announced certain principles as the basis upon which its slate of 
nominees was drawn up. I recommend this procedure to succeeding committees on nominations. The policy followed by the Committee in 1947 seems to be a good one; but whether or not the same policy is adopted by later committees, the important point, in my opinion, is that a definite policy be followed, and that the basis upon which the committee acts be made clear to the Conference as a whole.

Announcement of appointments for the Committees on Resolutions and Nominations will be made this afternoon. I recommend that the Chairmen get their committees together promptly and arrange for the necessary meetings. A committee room is available here in the hotel, and your Secretary, Mr. Ralph Smith, will arrange for whatever schedule of meetings you desire.

\section{STANDARDIZATION OF MEMBERSHIP ON STANDING NATIONAL CON- FERENCE COMMITTEES, AND NUMBER OF NATIONAL CONFERENCE VICE PRESIDENTS AND EXECUTIVE COMMITTEEMEN ${ }^{1}$}

The Chatruan. Two months ago Mr. Smith polled the Executive Committee on two questions which I think should now be presented to the Conference as a whole for final disposition. The first question was on the desirability of standardizing the number of members of all of the standing committees of the National Conference at five. In his letter to the Executive Committee the Secretary reported that establishment of this policy had been suggested, and went on to say:

It is said in support of this proposal that 5 years is long enough for a man to serve continuously on one committee, and that under this plan there would be a better opportunity for men to serve on various committees, the work of each committee would be expedited, the committee chairmen would be better able to conduct the affairs of the committees, and the smaller committees would probably function better and accomplish more, as compared with the present set-up in which three committees have seven members each. I have asked the chairman of each of the present seven-man committees for his opinion on the proposal to standardize on five-man committees. Two of them favor the change to five-man committees, and one favors seven-man committees. * * * A vote for the change will be understood to mean that on a seven-man committee, the membership will be allowed to drop down automatically and gradually to five member's under the plan of rotation now in effect; thus, 2 year's might elapse before the membership would level off at five members.

Two members of the original 24-member Executive Committee have retired from weights and measures work. Ballots on the proposed membership policy for standing committees were cast by all of the remaining 22 members of the Executive Committee, 15 ballots favoring the proposal and 7 ballots opposing it; of the latter, 1 ballot favored a reduction to 6 members rather than to 5 members as originally proposed. Thus the Executive Committee favors by more than a 2 to 1 majority the proposal that the policy of five-man standing committees be established.

Since the decision on this question will affect appointments to standing committees under our plan of lotating membership, I would ask that the Conference act now on this matter. To put the question formally before you I will ask the Secretary to propose a motion.

The Secretary. Mr. President, in conformance with the majority opinion of the Executive Committee, I move that the National Con-

\footnotetext{
1 See page 95 for report on reconsideration of action relative to Vice Presidents and iscecutive Committeemen.
} 
ference adopt the policy that standing committees of the Conference shall have five members each, but with the stipulation that the membership of present 7-man committees be not arbitrarily reduced, but be allowed to reach the new figure of 5 members automatically as members retire or as their terms expire under the plan for rotating membership which was put into effect at the Thirty-third Conference.

(The motion was seconded. Discussion was called for by the Chairman, and there being none the question was taken and the motion was agreed to.)

The Chamman. The second of the two questions presented to the Executive Committee also dealt with a matter of standardizing Conference procedure, and was presented in the Secretary's letter to the Executive Committee as follows:

From time to time in the past, questions have been raised regarding the number of members on the Executive Committee and the number of vice presidents. Once or twice, I beliere, the Conference as a whole has voted an increase in the number of vice presidents, but the general question of a suitable number of officers and Executive Committee members in proportion to the normal 250 total registration at meetings of the Conference has not been studied by the Executive Committee, and to a considerable extent the mattel has been left for decision to the nominating committee at each Conference. No specific proposal in this relation is now advanced. However, it seems to me that the Committee may wish to express itself on the subject, and that if there is a preponderance of opinion in favor of estabilshing a policy, now would be a good time to do this. If this were done the nominating committee would have a uniform pattern for its guidance each year.

The ballot form provided space for voting for or against the suggested policy, and in the case of each affirmative vote it was requested that there be shown the number of vice-presidents and the number of executive-committee members in addition to the officers-who are members ex officio-which the voter thought proper.

One executive committeeman did not vote on this question, only 5 negative votes were cast, and there were 16 voters in favor of establishing a definite policy, better than a 3 to 1 majority.

On the questions of the most suitable number of vice presidents and executive committeemen, the votes were somewhat scattered, although a definite preponderance of opinion was registered in favor of standardizing on 4 vice presidents and 10 elected executive committeemen. The complete results were as follows: for 2 vice presidents, 1 vote; for 4 vice preidents, 7 votes; for 5 vice presidents, 2 votes; for 6 vice presidents, 3 votes; and for 8 vice presidents, 1 vote. For elected members of the executive committee, 1 vote was cast for 7 members; 8 votes were cast for 10 members; 1 rote was cast for 14 members; and 5 votes were cast for 15 member's. One executive committeeman voted for standardization but indicated no preference as to numbers.

While we are on this matter I think it will be appropriate for the Conference as a whole to decide the issue, and to put the matter formally before you for action I shall ask the Secretary to propose a motion.

The Secretary. Mr. President, in accordance with the preferences expressed by the Executive Committee, I move that the National Conference adopt the policy of electing annually 4 vice presidents and 10 executive committeemen, the Executive Committee to consist of the elected member's plus the Conference officers, Ex officio.

(The motion was seconded.) 
Mr. Slough. Mas it not been the policy in the past for a definite vice president to preside at each session? If we have more than four sessions and only four vice presidents there would not be a rotation of presiding officers.

Mr. G. W. W ARner. I would favor five vice presidents, but I would rather hear other comments before making a motion to that effect.

Mr. Smeerry. The vote of the Executive Committee on this question was definitely split up. If those gentlemen could not come to any definite conclusion, it seems to me that it would be making a snap judgment for us to take action now. I think the matter should be settled by the Executive Committee.

The Cratrman. It is not quite right to say that the Executive Committee could not come to an agreement, because this was a mail poll; it wasn't as though they had come together to discuss it. It is admitted that the vote was scattered.

Mr. Fraser. I think what the members of the Execntive Committee who voted for this had in mind was to cut down the numbers to a point where they would not be unwieldy. It might be better to do just as was stated in Mr. Smith's motion.

Mr. Crawford. It has been suggested by a group around me that a reason be given why the number of vice presidents and members of the Executive Committee should be set at a particular number.

The Chamran. I think there are two considerations. First is the question, "Should we adopt a definite number at all?" If the Conference as a whole wishes to take such action, any working Committee might prefer to have it settled rather than to have it left open. The second consideration is the number of vice presidents and elected executive committeemen which would be most appropriate, and the object of this discussion is to develop ideas on this point.

Mr. Rogers. I remember that when I first came to this Conference we had four vice presidents which I believe was to give geographical distribution to the North, South, East, and West. That seemed to be a simple policy which always worked.

The Chatrman. Are there further comments? If not, let me summarize by saying that in this discrssion the remarks of some of the speakers have supported the motion, one speaker suggested that the number of vice presidents should be five instead of four but did not propose a formal amendment to that effect, and one speaker suggested that the question should be further considered by the Executive Committee but no motion was made to that effect.

Mr. Fisher. I move that the motion before us be amended to change the number of vice presidents from 4 to 5 .

(The motion to amend was seconded by Mr. Bakel and, there being no further discussion, the question was taken, and the motion was agreed to. The question on the amended motion being called for, a vote was then taken on the motion, as amended, to fix the number of vice presidents at 5 and the number of elected execu. tive committeemen at 10 , and the motion was agreed to. ${ }^{2}$ )

\section{APPOINTMENTS TO STANDING COMMITTEES}

The Chairman. We have two 5-man standing committees at the present time-Trading by Weight, and Specifications and Tolerances.

2 See page 95 for report on reconsideration of action on this motion. 
On the Committee on Trading by Weight the retiring member is Mr. A. J. Jensen of North Dakota; as his successor I am appointing Mr. J. F. True, from the grain-producing State of Kansas. On the Committee on Specifications and Tolerances, the retiring member is Mr. C. M. Fuller, of Los Angeles County, California, who has rendered long and valuable service on this particular committee; as his successor I am appointing another local official, well and I am sure favorably known to the Conference, Mr. L. E. Witt of Milwaukee, Wisconsin.

The other three standing committées will be considered in the light of the action which has just been taken by the Conference, under which membership on these committees will ultimately be reduced to five members each. On the Committee on Legislation the retiring member is Mr. V. D. Campbell, of Ohio. Also, I have accepted the resignation from this Committee of Mr. L. E. Witt, appointed, as I have just announced, to membership on the Committee on Specifications and Tolerances. This brings the membership of the Committee on Legislation down to the new base figure of 5 members.

On the Committee on Weights and Measures Education, the retiring member is Mr. R. D. Thompson, of Virginia. Mr. J. M. Paddock, formerly Superintendent of Standards of the State of Illinois, is no longer a member of this Committee by reason of his retirement from weights and measures activities. Mr. E. F. Usher, of Highland Park, Michigan, has resigned from this Committee, presumedly by reason of leaving weights and measures work; as his successor, to serve during the unexpired portion of Mr. Usher's term, I am appointing Mr. R. K. Slough, City Sealer of Weights and Measures of Akron, Ohio. The membership on the Committee on Weights and Measures Education is thus reduced to five members. I wish to say that when Mr. Bussey, former Chief of the State Division of Weights and Measures of Texas, joined the staff of the National Bureau of Standards, I designated Mr. J. T. Kennedy, Director of the Department of Weights, Measures, and Markets of the District of Columbia, as Chairman of the Committee on Weights and Measures Education and designated Mr. Bussey as Secretary of the Committee for the period until this Thirty-fourth Conference.

On the Committee on Methods of Sale of Commodities, the retiring member is Mr. F. J. Young, of Monroe County, New York. This is the only change on this Committee, and its membership will thus stand at six members for the ensuing year.

Each committee should meet before this Conference adjourns for the purpose of choosing a chairman and, if desired, a secretary, for the ensuing year, and of planning the activities of the committee for the next 12 months. The retiring chairmen should take the initiative in getting the committees together for this purpose, and upon request the Conference Secretary will be glad to schedule the meetings for the committee room here in the hotel.

I shall now turn the Chair over to Mr. Campbell who will act as presiding officer for the rest of this morning's session.

(At this point Mr. V. D. Campbell, Vice President of the Conference, assumed the Chair.) 


\section{ABSTRACTS OF STATE REPORTS}

CALIFORNIA

Br James E. Brenton, Chief, State Bureau of Weights and Measures

$\mathrm{Mr}$. Brenton reported the addition to his staff of three men during the past year'; two of these men act as liaison officers between the State Division and the county departments, one specializing on weighing equipment and the other specializing on measuring equipment. He also reported the acquisition of a 70-gallon testing standard for liquefied petroleum gas meters.

\section{CONNECTICUT}

Br Frank M. Greene, Deputy State Food and Drug Commissioner

Mr. Greene commented upon the increase in the number of type approvals of new weighing and measuring devices, made by his Department. He mentioned the increase in the consumption of fuel oil and gasoline, which had resulted in a redistricting of the State to adjust the territories of the several inspectors, and noted considerable activity in the field of liquefied petroleum gas. He announced that a new and more suitable location had been acquired for his laboratory, which would double the present space.

\section{DISTRICT OF COLUMBIA}

\section{Br Ralpi A. Montgomery, Inspector of Weights and Measures}

Mr. Montgomery reported that an educational program for staff members was being carried on by his Department. Two important current problems were noted as "prepackaged fresh meats" and "checkout counters"; it was suggested that manufacturers of check-out counter's should confer with weights and measures officials on new designs. It was reported that although the District of Columbia does not have a formal system of type approval, it is required that samples of devices be submitted for examination and test before being offered for sale.

\section{FLORIDA}

Br Nalls Berryman, Supervisor, State Division of Weights and Measures

Mr. Berryman reported the purchase of two additional mediumsized scale testing trucks and one portable unit for testing wholesale meter's and vehicle tanks. He said that a voluntary plan for the registration of scale mechanics had been placed in successful operation during the year, and that plans were under way to expand the activities. of the Division in the field of liquefied petroleum gas.

\section{IILINOIS}

\section{Br JoHn J. Livirt, State Superintendent of Standards}

Mr. Levitt expressed his pleasure over his return to weights and measures work after an absence of 8 years, and reported that much progress had been made by the Division during his absence. Two. 
large-capacity scale testing trucks are in operation and a purchase order for a third unit has been issued. He announced that plans were under way for an effective educational program within the Division. numerous personnel changes having been made.

\section{INDIANA}

\section{By William H. Roberts, Inspector of Weights and Measures of Vigo County}

Reporting for the State, Mr. Roberts announced that appropriations had been granted for two additional employees, for additional office standards and equipment, and for a new vehicle-scale testing unit. Office and laboratory space have been assigned in the new building of the State Board of Health which is to be completed this year. The Division is to be charged with the enforcement of a new "Sanitary Bedding Act," for which six new employees will be required.

\section{KANSAS}

\section{By J. Fred True, State Sealer of Weights and Measures}

Mr. True outlined the accomplishments of his Division during the two years of its existence. He pointed out that his Division operates only in the field of large-capacity scales, responsibility in other fields being divided among three other State agencies. He said that there was little activity with respect to small-capacity scales, gasoline pumps, and wholesale meters.

\section{KENTUCKY}

\section{By Geonge L. Johnson, Director, State Division of Weights and Measures}

$\mathrm{Mr}$. Johnson spoke of the accomplishments of the past year and the many problems which had arisen. Additional equipment has been obtained and a new vehicle scale testing unit will be delivered in July 1949. He reported that office and laboratory space for the Division is being provided in a new State office building soon to be started.

\section{IOUISIANA}

\section{By Allen F. Chappuis, Director, State Division of Weights and Measures}

Mr. Chappuis outlined the organization of the Weights and Measures Division under the law which became effective September 1, 1948. He expressed appreciation for the generous assistance of the officials of other States in connection with the training program conducted for the new inspectors of his Division. He commented upon the difficulties arising from the shortage of competent scale service men in the State.

\section{MAINE}

\section{By James A. Borle, Deputy State Sealer of Weights and Measures}

Mr. Boyle reported the enactment by the 1947 Legislature of a law authorizing the Commissioner of Agriculture to promulgate specifica- 
tions, tolerances, and regulations and amending the milk-bottle law to conform with the recommendations of the National Conference code. Specifications and tolerances as appearing in Handbook H29 were subsequently adopted. A general survey is in progress, which is expected to result in the preparation of a larger revision of the State weights and measures laws.

\section{MASSACHUSETTS}

By Jomn P. McBride, State Director of Standards and Necessaries of Life

Mr. McBride noted an increase in the number of weighing and measuring devices submitted to his office for pattern approval, pointing ont that some of these required very careful examination. He reported that a bill dealing with the sale of ice cream by weight was considered by the Legislature but failed of passage. Liquefied petroleum gas was mentioned as a problem which would require more attention in the future. Mr. McBride especially commended the excellent cooperation among States in the consideration of mutual problems.

\section{MICHIGAN}

By Wildian W. Bougmnm, Supervisor, State Division of Weights and Measures

Mr. Boughner reported that his Division has approximately 40 men making weights and measures and food inspections at the retail level; the State is divided into six regions, with a supervising inspector in charge of each. The Division operates two vehicle scale testing units and an equipment for testing vehicle tanks and wholesale meters, and is charged with the enforcement of a law requiring registration of weighmasters operating at livestock sale yards.

\section{MINNESOTA}

By Erung Haxsen, Supervisor, State Department of Weights and Measures

$\mathrm{Mr}$. Hansen said that the addition of 10 new inspectors had raised to 26 the number of inspector's now employed by his Department. Six new 1-ton panel trucks have been purchased, each equipped with a 100-gallon volumetric standard and complete equipment for testing small-capacity scales and retail liquid-measuring devices. The Department has also obtained one new 100-gallon standard and one new 500-gallon standard, each mounted on a trailer.

\section{MISSOURI}

Br Joseph A. Bminard, Commissioner of Weights and Measures, City of St. Louis

Reporting only for the City of St. Louis, Mr. Bernard reviewed briefly the activity of his Department and said that because of lack of sufficient personnel, work in some fields was limited. He men- 
tjoned particularly the check-weighing of packaged merchandise, and added that a comprehensive educational program is contemplated for the coming year.

NEVADA

\section{By Wayne B. Adans, State Sealer of Weights and Measures ${ }^{3}$}

Mr. Adams said that much of his old automotive equipment had been replaced with somewhat heavier vehicles, and that a 50-gallon, stationary, underground test measure liad been installed for the testing of gravity-type vehicle tank meters. The Sealer' of Weights and Measures is now charged with enforcement of an anti-freeze law enacted by the 1949 Legislature.

\section{NEW JERSEY}

\section{By Joseph G. Rogers, Deputy Superintendent, State Division of Weights and Measures}

Mr. Roger's reported the sudden death on May 11 of Mr. Joseph Giuliano, State Superintendent of Weights and Measures. He outlined the recent departmental reorganization, resulting from a new State constitution, the former Department of Weights and Measures being now a division of the Department of Law and Public Safety, headed by the Attorney General of the State. He described a systematic training program now under way, involving physical as well as technical training.

\section{NEW YORK}

By Clement A. Baner, Director, State Bureau of Weights and Measures

Mr. Baker spoke of the purchase by his Bureau of a new 100-gallon volumetric standard, and said that similar equipment had been obtained by several city and county departments. Short weight on coal deliveries brought into the State by trucks was said to be a major problem, and liquefied petroleum gas was said to be growing in importance. There was noted an increase in laboratory activities, and the procurement of some additional laboratory equipment.

\section{NORTH CAROLINA}

\section{By C. D. Baucom, State Superintendent of Weights and Measures}

Mr. Baucom reported the recent passage of eight weights and measures laws, four of these being for the purpose of clarifying existing statutes. Of the new laws, one establishes a standard loaf of bread, another regulates interstate traffic in coal, another transferred the Gasoline and Oil Inspection from the Department of Revenue to the Department of Agriculture, and another the control and regulation of liquefied petroleum gas from the Insurance Department to the Department of Agriculture. Appropriations for weights and measures administration were increased by the last Legislature.

3 In the absence of a delegate from Nevada the Secretary of the Conference presented the report which had been submitted by mail. 
Mention was made of two regulations recently adopted by the Board of Agriculture, one dealing with a standard measure for cucumbers and the other standardizing the "square" for roofing.

\section{NORTH DAKOTA}

\section{Br A. J. Junswa, Chief State Inspector of Weights and Measures}

Mr. Jensen commented upon the progress and expansion in the Weights and Measures Division, which operates three vehicle-scale testing units each carrying 16,000 pounds and one unit for the testing of wholesale petrolemm meters. He said that scales at stockyards are being tested each thirty days and that other public scales are tested approximately once every sixty days. He noted a rapid trend toward hearier and longer vehicle scales and mentioned liquefied petroleum gas as one of the major problems confronting his Division.

OHIO

\section{By Tromas M. Coldins, Deputy State Sealer}

Mr. Collins reported that two State-wide Weights and Measures Conferences were held during 1948 and two such meetings are planned for 1949, one already having been held. A request has been made for an appropriation to purchase an additional vehicle-scale testing unit. One new inspector has been added to the staff.

\section{OKLAHOMA}

Br R. Loute Fuanagan, State Supervisor of Weights and Measures

Mr. Flanagan said that he conld make no detailed report, since the Division of Weights and Measures was only in the process of organization as a result of a law recently enacted.

PENNSYLVANIA

By Simncer H. Seighman, Assistant Director, State Bureau of Standard Weights and Measures

Mr. Seighman reported that a school of instruction for city, county, and State inspector's had been held for one entire week during March 1948; there was an attendance of 82 percent of all inspectors in the State. During the past year special attention has been given to enforcement of the net-container law, with most satisfactory results. Of eight weights and measures bills sponsored in the last Legislature, six were enacted. It is proposed to purchase two new scaletesting trucks and two motorized units for testing liquid-measuring devices.

\section{RHODE ISLAND}

By Edward R. Fisher, State Seater of Weights and Measures

$\mathrm{Mr}$. Fisher made no report on activities, merely noting that Rhode Island was represented at the Conference by two members of the State Burean and one city sealer. 


\section{SOUTH CAROIINA}

By Alex H. Gibert, Chief State Inspector of Weights and Measures

Mr. Gibert traced the progress made in weights and measures regulatory work over a period of years. Since the last National Conference there has been placed in service at Columbia a vehicle-tank calibrating station. Also, a wholesale meter testing unit and a vehicle-scale testing unit carrying 20,000 pounds of test weights have been obtained and additional equipment is planned for the State. Liquefied petroleum gas was mentioned as a problem of increasing importance, and it was recommended that manufacturers of weighing and measuring devices do more toward the education of their customers in the use and care of such devices.

TEXAS

Br James J. Donnelly, Chief, Weights and Measures Division, City of Houston

Mr. Donnelly reported that during the year the State Division had placed in service two new vehicle-scale testing units, one carrying 26,000 pounds of test weights and the other carrying 11,000 pounds of test weights, thus making a total of four such units in service. A survey of prescription scales was made at the request of the State Board of Pharmacy and forty-four percent of the scales and thirty-six percent of the weights tested were found to be in error beyond tolerance limits. An effort is being made to obtain personnel and equipment for the systematic testing of grain hopper scales. A recent statute dealing with antifreeze will be enforced by the Division of Weights and Measures.

UTAH

Br E. C. Westwood, Sealer of Weights and Measures of Salt Lake City

Mr. Westwood conveyed greetings from Mr. Guy P. Stevens, the State Supervisor of Weights and Measures who was unable to be present at the Conference. Mr. Westwood reported that two scaletesting units are in operation in the State, but that no special equipment is available for testing wholesale meters or other devices for handling petroleum products in large amounts. It was anticipated that additional equipment and personnel would be obtained in the near future.

\section{VIRGINIA}

Bx R. D. Thompson, Supervisor, State Weights and Measures Section

Mr. Thompson reported that significant progress is being made in the small-capacity scale field and that two large-capacity scale testing units and one testing unit for wholesale meters are being operated by the State, which now has twelve full-time and two part-time inspectors. It was noted that a number of the cities of the State have active local departments. 


\section{WISCONSIN}

By George W. Warner, Supervisor, State Weights and Measures Inspection

Mr. Warner said that his Department had requested an increase in appropriations but that the result was in doubt as the Legislature was still in session. He mentioned special problems in connection with the food canning industry and in connection with purchases of products from farmers by commercial truckers. A special problem awaiting solution was said to be the development of an adequate test for a device known as a "tenderometer" for determining the tenderness of peas.

\section{WYOMING}

By Charles H. Oakier, State Inspector of Weights and Measures

Mr. Oakley reported that the weights and measures program in his State was developing. It is planned to obtain two new vehicle-scale testing units, and this will bring about the addition of at least one man to the weights and measures staff.

ABSTRACTS OF REPORTS OF REPRESENTATIVES OF STATE AND REGIONAL ASSOCIATIONS OF WEIGHTS AND MEASURES OFFICIALS

CALIFORNIA ASSOCIATION.OF WEIGHTS AND MEASURES OFFICIALS

By Whumam A. Keruin, Sealer of Weights and Measures of Alameda County, Calif.

Mr. Kerlin noted that the Association is now 13 years old and said that it is striving to assist in bringing about uniform interpretation and enforcement of requirements throughout the State. The Association sponsored several bills during the last legislative session, including the controversial issue of selling ice cream by weight; the ice cream bill failed of passage, but the Association plans to sponsor a similar bill in 1951.

\section{CONNECTICUT SEALERS' ASSOCIATION}

By Donald A. Fraser, Seater of Weights and Measures of New London County, Conn.

Mr. Fraser noted that the annual meetings of the $A$ ssociation are now held in October instead of January, and that a summer meeting is also held each year. Members of the Association are active in the fields of legislation and public relations. The Twenty-first annual meeting of the Association will be held in New London on October 27 and 28.

IILINOIS WEIGHTS AND MEASURES ASSOCIATION

\section{By JoHn J. Levrte, State Superintendent of Standards}

Mr. Levitt noted that the Eleventh Annual Conference of the Association was held in Chicago in August 1948 and that plans were underway for the 1949 meeting, although the time and place for this meeting had not been definitely decided upon. 


\section{INDIANA ASSOCIATION OF INSPECTORS OF WEIGHTS AND MEASURES}

By C. C. Mongan, Sealer of Weights and Measures of Gary, Ind.

Mr. Morgan said that the Association was continuing its policy of . having two meetings a year. The 1949 anmual meeting, which was the Thirty-sixth Annual Conference of the Association, was held jointly with the National Scale Men's Association in Indianapolis in April. Special mention was made of the question-and-answer feature of the Association meetings; approximately 500 questions and answers, discussed over a period of the past eleven years, have been published in looseleaf form and new material will be added from time to time.

MASSACHUSETTS WEIGHTS AND MEASURES ASSOCIATION

Bx Enwaki H. Junkrss, Sealer of Weights and Measures of Salem, Mlass.

Mr. Judkins announced that the 1949 meeting of the Association would be held in Holyoke early in October.

MICHIGAN ASSOCIATION OF WEIGHTS AND MEASURES OFFICIALS

By Wimlam B. Heaslip, Supervising Inspector of Treights and Measures of Detroit, Mich.

Mr. Heaslip commented on the fact that quarterly regional meetings of the Association are held, in addition to the annual meeting of the organization. The Thirty-fifth Annual Conference was held in Grand Rapids in February 1949, and it was said that one of the important subjects considered at this meeting was short weight in packages of flour.

\section{NEW YORK STATE WEIGHTS AND MEASURES ASSOCIATION}

Br Robert Willians, Sealer of Weights and Measures of Nassau County, N.Y.

Mr. Williams reported that in addition to the ammual meeting of the Association, 4 one-day regional meetings are held in different parts of the State. He mentioned the forty-first annual meeting which was held in Oswego in July 1948, and ammounced that the 1979 meeting will be held in Rochester on July 19-21. It was noted that the Association made an unsuccessful effort to bring about enactment of a standard-weight bread law.

\section{NORTHWEST WEIGHTS AND MEASURES ASSOCIATION}

By Carl I. Hoel, Assistant Supervisor, Minnesota State Department of Weights and Measures

Mr. Hoel mentioned that the Northwest Association has a membership from 7 of the Northwestern States, totaling approximately 400. The 1948 meeting of the Association was held in St. Paul, Minn., in May of that year and the 1949 meeting will be held in Minneapolis on June 27-29. 


\section{OHIO SEALERS' ASSOCIATION}

By Andrew C. Dotzauer, Deputy Sealer of Weights and Measures of Hamilton County, Ohio

Mr. Dotzauer reported that during 1948 the Association had held four sectional meetings and two State meetings. He stated that the Association has been actively supporting a move for an additional scale-testing unit to be operated by the State.

PENNSYLVANIA ASSOCIATION OF INSPECTORS OF WEIGHTS AND MEASURES

Br Gondon S. WatKnns, Sealer of Weights and Measures of Luzerne County, $P a$.

Mr. Watkins reported a very well attended 1948 meeting of the Association, a special feature of which was an entire day set aside for a continuation of the school of instruction which had been held in Harrisburg by the State Bureau; it was stated that this item will again be featured at the 1949 meeting to be held in Hazleton on September 21-24. It was noted that the legislative committee of the Assocciation had been particularly active in sponsoring legislative changes.

SOUTHERN WEIGHTS AND MEASURES ASSOCIATION

Br C. D. Baucom, State Superintendent of Weights and Measures of North Carolina

Mr. Baucom commented upon the 1948 meeting of the Association which was held in Dallas, Texas, in June, and reported that at that meeting a Constitution and By-Laws for the Association were adopted. 'The next meeting of the Association is to be held in Biloxi, Mississippi. on November 1-3, 1949.

\section{TEXAS WEIGHTS AND MEASURES ASSOCIATION}

By Frank G. Yarbrough, Deputy Sealer of Weights and Measures of Dallas, Texas

Mr. Yarbrough said the first meeting of the Association since 1942 was held jointly with the Southern Weights and Measures Association in Dallas in 1948, and announced that no plans are under way for a meeting of the Texas Association in 1949. He stated, however, that a training school would probably be held late in the year.

\section{VIRGINIA WEIGHTS AND MEASURES ASSOCIATION}

By Weister K. Tripple, Chief, Bureau of Weights and Measures of Norfolk, $V$ a.

Mr. Tripple commented on the fact that meetings of the Virginia. Association have always emphasized the instruction of State and local inspector's. He noted the fourteenth annual meeting of the Association which was held in October 1948 at Old Point Comfort, and announced that the 1949 meeting will be held in Roanoke on October 13-14. Mention was also made of the cooperation extended by the Association in the preparation of the motion-picture film entitled "Getting Your Money's Worth".

(At this point, at 12:30 p. m., the Conference recessed for luncheon.) 


\section{SECOND SESSION-AFTERNOON OF TUESDAY, MAY 24, 1949}

(The Conference reassembled at 2:10 p. m., R. S. Ackerman, Vice President of the Conference, presiding.)

\section{APPOINTMENT OF WORKING COMMITTEES AND MISCELLANEOUS ANNOUNCEMENTS BY THE SECRETARY}

The Secretary. Speaking for the President of the Couference, I wish to announce his appointments for the working committees of this Conference, as follows:

On the Committee on Resolntions: Mr. J. E. Brenton, of California, Chairman; Mr. L. E. Witt, of Milwaukee, Wis., the 1947 Chairman of the corresponding Committee; Mr. C. A. Baker, of New York; Mr. J. M. Boucher, of the District of Columbia; Mr. H. E. Crawford, of Jacksonville, Fla.; Mr. J. M. Dietz, of Union County, N. J.; Mr. J. W. Reese of Iowa.

I may say that the purpose of appointing to membership this year the chairman of the corresponding committee of the preceding year is to provide some continuity of thinking and procedure.

On the Committee on Nominations: Mr. Erling Hansen, of Minnesota, Chairnan; Mr. V. D. Campbell, of Ohio, the 1947 Chairman of the corresponding Committee; Mr. C. M. Fuller, of Los Angeles County, Calif.; Mr. E. H. Judkins, of Salem, Mass.; Mr. G. H. Leithauser, of Baltimore, Md.; Mr. J. G. Rogers, of New Jersey; Mr. H. L. Shankle, of North Carolina.

A committee room is available here at the Hotel, and I shall be glad to schedule meetings of working or standing committees to be held in this committee room, upon the request of the chairmen of the several committees.

Let me remind the standing committees of the Conference that it is incumbent upon each committee to organize during this meeting, electing a chairman, and if considered necessary a secretary, for the ensuing year. At such a meeting plans may be made for activities during the coming year. The responsibility for calling the new committees together for this purpose rests upon the present chairman of each committee.

In relation to the program for this National Conference, I wish to say that this program has been built almost entirely around suggestions received from the membership; practically every item on the program is one that has been suggested by one or more members of the Conference.

The placement of the committee reports on our program this year has been dictated by a desire to give as much time as possible for the Conference as a whole to consider the committee reports in advance of the time these reports are presented for action. That is particularly important in the case of the more voluminous reports and 
those which might possibly be controversial; that is the reason for placing the Report of the Committee on Specifications and Tolerances on our Friday program, so as to allow the very maximum of time during the meeting for study and consideration, in advance of the presentation of the Report, of the Tentative and Final Reports of the Committee on Specifications and Tolerances.

For purposes of the record, I wish to note that the Final Report of the Committee on Specifications and Tolerances, which is amendatory to the Tentative Report which was so widely distributed by mail in advance of this meeting, was available on our table this morning when our meeting opened. Material will be placed on the table at the back of the room from time to time, from which you may help yourselves; after a speaker has presented a formal item on the program, if copies of this are available in mimeographed form, these will be placed on the table. We believe that we have provided an ample supply of this mineographed material, but it is, of course, advisable to conserve the supply because it is difficult during the meeting to obtain the emergency mimeographing service which will be necessary if we have to l'un off additional copies:

Mr. Berryman is not in the best of health and has asked to be excused from presiding during this meeting. Dr. Condon will be the presiding oflicer tomorrow at the meeting which will be held at the National Bureau of Standards, and arrangements will be made for a substitute for Friday when Dr. Condon was originally scheduled to preside. Following the morning session tomorrow, there will be a tour of the Bureau of Standards laboratories; small groups will be arranged, each in charge of a guide, and visits will be made to as many of the points of interest as is practicable within the two to two-and-one-half hours at our disposal for this toux.

Tomorrow evening the regular Conference party will be held, to which all delegates and guests and their ladies are invited. The party is scheduled to begin at 9 o'clock and to end at midnight; there will be dancing, a bit of entertaimment, and a bit of food. TVe lope that all of you will attend and will not talk too much business, but will just enjoy yourselves and get acquainted; that is the purpose of the party.

For purposes of the record, I wish to note that the increase in the registration fee to $\$ 5.00$, effective this year, was authorized by the Executive Committee of the Conference as a result of consideration given to the depleted condition of our treasury; there was a question of increasing the reoistration fee or practically eliminating the evening party, and the decision was to increase the fee and to continue the party as it has been held in the past.

Please register! The registration list is the official record of those who are present, it forms the list included in the printed report of the Conference, and it is this list which is used for the distribution of material which may be issued following adjournment of the Conference, including the printed report. It is important, from your stanclpoint and ours, that everyone attending the Conference register at the rlesk.

By now many of you have noted the absence from our meeting this year of two people who have been regular attendants for a long time; I refer to Mr. and Mrs. J. W. Saybolt. I regret to inform you that on March $26 \mathrm{Mr}$. Saybolt experienced another light heart attack, as 
a result of which he has been under the order's of the Doctor to be quiet ever since. This attack was much less serious than the former one and he is well on his way to recovery but still is under the necessity of taking things very, very quietly. As a result of this circumstance, Mrs. Saybolt felt that her place was with Mr. Saybolt during his period of recovery and that she could not attend our meeting this year; she tells me that this is the first Conference which she has missed since 1929, and she regrets very much this break in her attendance. I am advised that Mrs. Carrie Woodland will be Mr's. Saybolt's chief deputy and that Mrs. Margaret Meek will be her second deputy to take care of renewals and new subscriptions to the Scale Journal which Mrs. Saybolt would normally handle; both of these ladies will be happy to receive new subscriptions or renewals, and I suggest that you contact one or the other of them while you are here to take care of any matters in relation to the Scale Journal.

I wish to report an interesting occurrence of a short time ago. I received a letter from Mr. R. L. Jefferis of the IV. \& T. Avery Company in Australia. Mr. Jefferis is Supervisor of the Company at Sydney. I quote from his letter: "Cordial greetings and best wishes from scale men in Australia to their colleagues in U. S. A." I pass that message on as a nice gesture of international cooperation.

You will have noted that the mimeographed report of the Committee on Legislation shows this to be signed by only a small number of the members of that Committee. When it became necessary for me to send this report to be mimeographed I had received approval of that Tentative Report only from the Committee members whose names are appended to the mimeographed document. Subsequently, Mr. Baker, Mr. Campbell, and Mr. Witt signified that they subscribed to that report.

REPORT OF THE NATIONAL CONFERENCE COMMITTEE ON LEGISLATION, PRESENTED BY ROLLIN E. MEEK, CHAIRMAN

Your Committee on Legislation has been comparatively inactive since the adjournment of the Thirty-Third National Conference due to the fact that few matters of pressing importance were brought to its attention. Nevertheless, the Committee is of the opinion that the Conference is entitled to a report on its present position with respect to recommendations made and accepted during our last meeting. In addition, the Committee is prepared to report on a survey it has made of existing State weighmaster legislation.

Federal Standard Food-Pachage Tegislation.-Referring first to proposed food-package standardization legislation considered during previous meetings of the Conference, you will recall that this was a matter left in the hands of the Committee for further study. The Committee wishes to report that it has endeavored to keep in touch with this situation but has received no new proposals which would seem to warrant Conference action at the present time. The Committee strongly favors the Conference reiterating its position of endorsing "in principle," food-package standardization and being on record as welcoming cooperation from industry in bringing this about.

Regulation of Repairmen.-With respect to proposed legislation either licensing or bonding repair agencies and those engaged in mak- 
ing repairs on weighing or measuring devices, the Committee wishes to take the position there has been very little, if any, crystallization of thought along this line. It has been suggested that a centralized accrediting agency be developed for the purpose of assisting the States in connection with the establishment of fitness regulations of repairmen. Furthermore, voluntary registration systems have been put into effect in at least two States and are understood to be giving good results.

The Committee is cognizant of the many unorthodox practices engaged in by unscrupulous repairmen and believes that, unless a more adequate weights and measures supervision is provided, it will eventwally be necessary to press for legislation based on one or a combination of the proposals advanced. The Committee is of the opinion that the Conference should go on record as recognizing the desirability of legishation which would give maximum protection to all parties concerned in the matter of proper repairing or servicing weighing and measuring devices. To accomplish the objective the Committee invites the cooperation of everyone engaged in the manufacture, installation, repairing, operation, and testing of weighing and measuring devices.

Uniform Weighmaster Legislation.-Your Committee has been requested, by the Secretary of the Conference, to explore the field of weighmaster leglislation. This is for the dual purpose of analyzing existing legislation and of developing sentiment in the Conference as to the advisability of incorporating a section or sections in the Model Law on Weights and Measures relating to weighmasters. The Committee approached this assignment with the understanding it was originally created for the purpose of considering legislation introduced or proposed to be introduced into the Federal Congress and that it was not contemplated, at that time, that the Committee would undertake the drafting of legislation.

While the Committee realized it was exceeding the strict letter of its authority, it appeared appropriate to comply with this request. As a "Committee on Legislation," it seems expedient for the Committee to go beyond the strict limits of the original intent, and to present to the National Conference, at any time, any suggestions it deems advisable in the field of weights and measures legislation. Therefore, the Committee recommends, if its report is adopted by the Conference, that such action be interpreted as a formal extension of the Committee's authority to take similar action at any future time.

The Committee has taken no steps toward drafting any proposed weighmaster legislation. Its efforts have been limited to obtaining copies of existing laws and ordinances on the subject and to contacting weights and measures oflicials throughout the country with regard to any suggestions they might wisli to offer for incorporation in the Model Law. In this connection the Committee's efforts were highly successful. The information received will prove extremely valuable to the Committee in the event this report is accepted. In such case, the Committee will pursue its studies on weighmaster legislation during the coming year, and be in readiness to propose something for the consideration of the 35th National Conference.

It will be impossible, in the brief time allotted for the submission of this report, to go into great detail with regard to weighmaster laws 
and ordinances in effect in weights and measures jurisdictions throughout the country. The lack of uniformity in these laws and ordinances, as well as the regulations relating thereto, stresses the advisability of the Conference incorporating into the Model State Law on Weights and Measures a section or sections relating to weighmasters.

In briefly summarizing some of the requirements of the many laws and ordinances dealing with weighmasters and coming to the attention of the Committee, it should be pointed out:

1. Weighmasters are generally classed as "public weighmasters" or "private weighmasters."

2. A "public weighmaster" may be considered as a corporation, company, or individual who shall, for hire, weigh or measure any commodity, produce, or article and issue therefor a certificate of weight

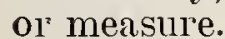

3. A "private weighmaster" may be any corporation, company, or individual not engaged in the business of weighing or measuring for hire, who requires the services of a certified weighmaster in his business.

4. Weighmasters are customarily subject to penalties and revocation of their licenses for misrepresenting the quantity of commodities weighed or measured by them.

5 . In most instances, the supervising official or agency is empowered to adopt rules and regulations but, when this is done, there is little semblance of uniformity in these.

6. In some jurisdictions firms or individuals engaged in weighing such commodities as solid fuel, tobacco, and livestock are required to be certified as weighmasters.

7. Those engaged in weighing or measuring for hire are required to be certified as weighmasters in some jurisdictions while in others they are not.

8. Weighmasters are appointed for definite terms varying in length in different jurisdictions. Some jurisdictions require the payment of a fee upon appointment or renewal thereof while others do not.

9. In some jurisdictions, weighmaster's are required to furnish bond, while in other's they must take an oath to faithfully execute their duties.

10. Some jurisdictions require weighmasters to provide themselves with seals, while others do not.

11. Many jurisdictions are extremely lax with respect to weighmasters certifying tare weights not obtained by them which, in many instances, are believed to have resulted in inaccurate net weights.

12. Many jurisdictions permit weighmaster's to certify weights where the gross weight exceeds the nominal capacity of the scale, or is obtained by "two-end weighing."

The Committee, in calling attention to the foregoing requirements of existing legislation and regulations relating thereto, does so for the sole purpose of impressing the Conference with the importance of attempting to do something toward bringing about greater uniformity in weighmaster legislation. Only a few of the many non-uniform requirements to be given attention by the Committee, in the event it is authorized to draft model legislation, are listed.

The Committee is of the opinion that there is a greater need for weighmaster legislation, particularly uniform legislation, than ever before. The trucking of commodities has become big business and evidence indicates that it is still on the increase. The use of inadequate 
scales to weigh large trucks has undoubtedly resulted in a high percentage of inaccurate weighings. These trucks haul for long distances with the results, all too frequently, that either the buyer or the seller or both do not have an opportunity to observe the weighings. Since they must depend upon someone to look after their interests, why should not the weighmaster be licensed and bonded to faithfully execute his duties? Uniformity in weighmaster legislation would be of special benefit to those who pay freight charges or buy or sell commodities comprising interstate shipments.

The Committee's brief study of existing weighmaster legislation leaves it with the conclusion that such legislation is weak, antiquated, and contradictory, and, because of this, difficult of enforcement. It is of the opinion that these evils can best be eliminated by the Conference incorporating into the Model Law a section or sections relating to weighmaster's to serve as a guide for State and local legislative bodies.

R. E. Meex, Chairman,

C. A. BAKER,

J. A. Bernard,

J. R. BOO'TH,

V. D. Campbell,

L. E. WitT,

F. C. Yarbrough, Committee on Legislation.

(It was moved by Mr. Meek and seconded by Mr. R. D. Thompson that the Report of the Committee on Legislation be adopted, the question was taken, and the motion was agreed to.)

\section{LIQUEFIED PETROLEUM GAS}

UNITS OF MEASUREMENT-BY J. F. BLICKLEY, DIRECTOR, BUREAU OF STANDARD WEIGHTS AND MEASURES, STATE OF PENNSYLVANIA

The subject I am about to discuss is apparently the new problem child of weights and measures officials over the entire country.

When our efficient Secretary, Mr. Ralph Smith, selected and requested me to discuss this topic of units of measurement particularly as they relate to retail consumers, I solicited the experiences of weights and measures officials of other States. From the replies I have received, I am convinced this problem of units of measurement of liquefied petroleum gas is of major importance and should receive the attention of this Conference immediately. Further delay in adopting methods of sale, specifications for devices used, uniform laws or regulations governing the method of sale of liquefied petroleum gas, and strict enforcement of the same will only add to the existing confusion and unsatisfactory methods of sale and make our problem more difficult to solve.

Liquefied petroleum gas that is sold to the consumer in bottles, cylinders, or the more common term "Tank," is definitely a commodity in package form. From inquiries made of different States, I am advised that in States which have commissions or some other form of government controlling public utilities, it is not considered or recognized as a utility. This places the function of control and regulation under the jurisdiction of Weights and Measures Bureaus unless some special function of State government is set up to control this commodity. 
Like myself it appears that many weights and measures officials, manufacturers of weighing and measuring devices, and the public in general were of the opinion that liquefied petroleum gas was a utility and came under the superrision and control of commissions or divisions of State govermment set up for this purpose. I was somewhat amazed when the first complaint received in Pennsylvania, which was made to our Public Utility Commission, was referred by them to the Bureau of Weights and Measures for investigation and satisfactory adjustment. Further inquiry and study magnified the revelation that we had a new problem to contend with.

That liquefied petroleum gas was considered a utility is further manifested by the amazement expressed by manufacturer's of meters when it was called to their attention that the meter was a measuring device that came under the provisions of weights and measures laws, and that type approval was necessary in individual States that have this provision in their law. Meters of the type used in measuring liquefied petroleum gas are of the same construction and contain the same functioning methods as meters used for measuring manufactured or natural gas.

Meter's used for measuring manufactured or natural gas must stand inspection by the several utility commissions, and manufacturers were - sincere and honest in their conjecture that once the meter was approved by these bodies it could be used legally in the sale of liquefied petroleum gas. They did not realize this commodity was an entirely different commodity than manufactured or natural gas that came under the jurisdiction of separate State agencies. My personal convictions are that misunderstanding and confusion were the only reasons weights and measures officials were not consulted to approve their devices, that their actions were neither deliberate or wilful, and that it was entirely unintentional on their part to circumvent any of our laws, rules, and regulations.

The first consumer's conplaint received in our jurisdiction added further proof of the existing confusion. 'The distributor was not cooperative and resented our visit to conduct an investigation. We tried to explain our situation and the problem involved, but of no avail; as this was our first experience and realizing that the same misunderstanding and confusion existed in his mind, we hesitated in using the power granted under the law. Consistency was victorious and we finally convinced the distributor it was not a utility and came under the jurisdiction of our Bureau. Sales were on a weight basis and he was advised how to operate on this basis.

Results from information solicited from other State officials as to the best method of sale for liquefied petroleum gas shows that opinion is about equally divided between the weight basis and the cubic-foot meter-measure basis of sale. Each has its advantages and disadvantages; arguments could be advanced proving the advantages and disadvantages of either method. Please understand I am not promoting or attempting to offer an advantage for either method of sale. I am only trying to be a good umpire by calling them as I see them.

At the present time when sold by reight the consumer is at the mercy of the person making the delivery. No matter how honest a person may be, he is not infallible; errors can be made unintentionally, and when this occurs the consumer pays with no chance whatsoever of the error being rectified. 
It can be said this occurs whenever sales of any commodity are made by weight. This is true; however, in practically all cases where commodities are sold for household consumption the purchaser has either an opportunity to witness the weighing operation or the means at his disposal to check against error. This is not true in the sale of liquefied petroleum gas. Very few delivery trucks are equipped with weighing devices to do the weighing operation at the point of delivery where it can be witnessed by the consumer, and weighing devices on trucks so equipped are placed in such a position that it is impossible to read the indicating elements from the ground. In order to witness the weighing operation the consumer must climb upon the delivery vehicle to read the indicating elements of the scale. With very few exceptions this obligation becomes the duty of a female member of the lousehold. This is a very dangerous obligation and a hazard to the safety of the person viewing the weighing operation, be it male or female.

When sales are on a weight basis most of the weighing is done at the warehouse of the distributor and a bill is furnished to the consumer stating the net amount of weight receiverl. The consumer has no way whatsoever to determine if the statement of weight to be paid for is correct; again the consumer is at the mercy of the person doing the weighing and must pay for the amount of liquefied petroleum gas billed. When tanks are collected to be returned to the distributor, the consumer is also at the mercy of the operator of the vehicle or the person in charge at the distributing plant who determines if any liquefied petroleum gas remains in the tank which was removed. In many cases the consumer, in order to be assured that sufficient gas is on hand at all times, order's well in advance, and tanks are not empty when they are removed from the consumer's residence. At the present time many distributors are installing the twin-tank system which will assure the consumers of having sufficient gas at all times for their needs; at regular intervals one of the tanks is removed by the distributor and a new tank supplied in its stead, the consumer to receive credit for any remaining gas left in the tank. Again the consumer has no assurance that full credit is received for gas left remaining in the tank. On trucks equipped with weighing devices the hazardous obligation must be gone through if the consumer desires to witness the weighing of the tank removed. In cases where a consumer is away from home when gas is delivered and an empty tank removed there is no certainty that full credit will be given for any gas left remaining in tanks thus removed.

Up to the present time I have not received any complaints of partly filled tanks being delivered on a weight basis and a charge being made for full tanks; liowever, this is possible and can occur. It is also possible that unscrupulous merchants and itinerants may enter this new and enterprising business field, creating a racket very similar to the conditions that existed in the delivery of solid fuel ten to fifteen years ago. Under present conditions this would be very simple. As weights and measures officials we must be on guard and adopt strict regulations to prevent racketeers and unscrupulous persons setting up a business in this manner. Established and legitimate merchants will be protected from unfair competition as they are always ready 
and willing to cooperate and abide by rules and regulations which protect the consumer from being willfully cheated. It will also protect a fair and legitimate profit for honest merchants as unfair competition is usually practiced by the unscrupulous in having the consumer believe their rates are lower, when in fact short weight or measure is deliberately and willfully delivered. We as weights and measures officials are aware of the methods used. The unthinking consumer who does not stop to analyze and is governed by appearance and general impressions is not aware of the practices used to deceive. Our initial duty is to protect the vast multitude, which comprises the inexperienced consumer, from fraud and deception.

Then liquefied petroleum gas is sold on a weight basis the tare weight should be die-stamped in a conspicuous place on the tank, and the delivery vehicle should be equipped with a scale suitable for weighing the tank and so positioned on the vehicle that the indicating elements can be easily read without the person witnessing the weighing mounting the vehicle. A certificate showing the gross, tare, and net weights should be furnished the consumer at the time of delivery. When tanks are removed from the premises of the consumer it should not be taken for granted that they are all empty. They should be weighed and credit certificates issued immediately for all weight in excess of the tare weight which is die-stamped on the tank. Tanks should be checked periodically for any change of weight that may occur and be restamped if any change does occur.

Liquefied petroleum gas is also being sold on the basis of a cash consideration for the tank with no attempt being made to advise the consumer how much gas either by weight or volume is contained in the tank. This method of sale is contrary to the provisions of laws in most jurisdictions. The consumer has absolutely no assurance that the tank is quarter-filled, half-filled, or completely filled. I do not believe it is the intention of any honest merchant to willfully deliver a tank partly filled to the consumer and bill the consumer for a full tank. Again I must say no person is infallible and no mechanical devise used in gauging tanks thus filled has yet been invented that will not get out of order. It is my personal opinion that this is absolutely the poorest method of sale and should be eliminated in jurisdictions where laws forbid the sale of commodities in this manner. I have always been an advocate of net-content declaration appearing on all commodities put up in package form, be it food, food products, marbles, or peanuts; the purchaser is entitled to be advised of the quantity received and paid for. It being definitely established that liquefied petroleum gas is a commodity in package form, no exception should be made. Concentrated effort should be made to stop this method of sale at once in jurisdictions where laws or regulations permit.

A review of the method of sale by volume through gas meters is confusion exemplified. It was astonishing to learn of the varying indexes that appear on meters for the sale of liquefied petroleum gas. In addition to the countless numbers now in use, many additional modifications can be furnished and applied to meters used for sale of liquefied petroleum gas by volume. On the surface it appears that any seller of this product can make a new determination and request a 
different index on the meter to further add to the confusion. For your information the following is a partial list of indexes now appearing on liquefied petroleum gas meters:

\section{On Propane Gas Meters}

Decitherms : 1 Decitherm $=3.85$ Cubic Feet.

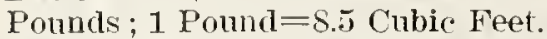

Essotane Units: 1 Essotane Unit $=0.85$ Cubic Feet.

Equivalent Cubic Feet: Equivalent Cubic Feet converted from 2,550 B. T. U. to 530 B. T. U. 4.5 Units $=1$ Cubic Foot.

Happy Cooking Standards; 1 Happy Cooking Standard=0.85 Cubic Foot.

Fast Flame Kiloflames ; 1 Fast Flame Kiloflame=1.35 Cubic Feet.

Kiloflames; 1 Kiloflame $=\mathbf{1 . 3 5}$ Cubic Feet.

Sungas Kiloflames; 1 Sungas Kiloflame=1.35 Cubic Feet.

Pottergas Units : 1 Pottergas Unit=0.20s Cubic Feet.

Public Gas Kilofanes ; 1 Public Gas Kilof ame=1.35 Cubic Feet.

Metered Homegas Units ; 4.811 Metered Homegas Units=1 Cubic Foot.

Equiralent Cubic Feet: Equivalent Cubic Feet convelted from 2,550 B. T. U. to 550 I. T. U. 4.636 Units=1 Cubic Foot.

K. W. H. ; 1 K. W. H. $=1.35$ Cuhic Foot.

Decitherms ; 1 Decitherm $=3.94$ Cubic Feet.

Standard Cubic Feet, Ratio 100 to 1.

Standard Cubic Feet, Ratio 500 to 1.

Cubic Feet, Ratio 21.00 to 1.

Vajore Units: 0.1 Cubic Foot per unit, Ratio 100 to 1.

Shorgas Units; 4.25 Cubic Feet per unit, Ratio 42.8 to 1.

Deritherms ; 2,520 B. T. U. per Cubic Foot, Ratio 39.63 to 1.

Therms ; 2,520 B. T. U. per Cubic Foot, Ratio 34.63 to 1.

Pounds; 8.56 B. T. U. per Cubic Foot, Ratio $\$ 5.56$ to 1.

\section{On Butane Gas Meters}

K. W. H. ; 1 K. W. H. $=1.05$ Cubic Feet.

Therms; 1 Therm=30.7 Cubic Feet.

Decitherms ; 1 Decitherm $=3.07$ Cubic Feet.

Decitherms: 1 Decitherm $=3.125$ Cubic Feet.

Pounds; 1 Pound=6.25 Cubic Feet.

K. WV. H. ; 1 K. W. H. $=1.05$ Cubic Feet.

Gallons : 1 Gallon $=32$ Cubic Feet.

Cubic Feet : 3.200 P. T. U. to 550 B. T. U., Ratio 16.56 to 1 .

Decitherms ; 3,200 B. T. U. per Cubic Foot, Ratio 31.28 to 1 .

Gallons; 32 Cubic Feet per gallon, Ratio 32.03 to 1.

Therms ; 3,200 B. T. U. per Cubic Foot, Ratio 31.28 to 1.

Pounds; 7.4 Cubic Feet per pound, Ratio 73.94 to 1 .

\section{On Mixen Gas Meters}

Decitherms: 1 Decitherm $=4$ Cubic Feet.

Equivalent Cubic Feet converted from 2,750 B. T. U. to 537 B. T. U. 5.12 Units=1 Cubic Foot.

By no means are the afore-mentioned indexes a complete list of all that are in use at the present time. I am going to be frank and admit that I became so confused in trying to accumulate all the indexes to use in this subject, and due to the lack of time, I was forced to give up further study. All the above-mentioned and unmentioned indexes can be furnished either in a circular-read or straight-read type meter; multiply the confusion by two, then try and visualize our problem.

No matter what kind of an index is used the meter must be checked and proven on a cubic-foot basis. It makes no difference what index is used, the meter has a cubic-foot proving circle or test hand; this means one revolution of the meter mechanism displaces a controlled volume. The gas is actually measured in cubic feet and converted to 
one of the trick terms by gears which drive the remaining dial hands on the index; this gear train adds up the revolutions of the cubic foot test hand so that an accumulative count of the revolutions of the test hand can be obtained. Therefore, the dial must register in cubic feet to be substantiated theoretically, actually, or legally.

As the gas is actually measured in cubic feet there seems to be no apparent or good reason why it should be converted to the many different nonstandard terms now in use. Look over some of the ridiculous indexes used: "Happy Cooking Standards," "Kiloflames," "Homegas Units," "Pottergas Units," "Vapyre Units," "Shorgas Units," "Sungas Kiloflames," "Fast Flame Kiloflames." What do they mean? My answer is that they are meaningless, they have no comparison to any standards of measure adopted in these United States or any other domain on the universe. Surely there is some motive for their adoption and use. The terminology that is being used means absolutely nothing to the user of liquefied petroleum gas.

The many meaningless indexes used at the present time no doubt create an uncalled-for nuisance to the manufacturer, who is obliged to furnish the type of meter index requested by the customer. This muisance in manufacture will increase unless we as weights and measures official act promptly to eliminate these nonstandard meaningless terms that appear on meters. The meter is the same construction from top to bottom regardless of what index is used; changes become necessary in the gear train for the various indexes. It is only reasonable to assume manufacturers of meters would welcome a standard-term index as it would simplify their manufacturing problems. As actual measurement is made by the cubic-foot basis which must be converted to the ridiculous, meaningless, and nonstandard terms, this term should be "Cubic Feet."

Through the years many problems as great, or perhaps greater, have been solved through the National Conference on Weights and Measures; these achievements have been accomplished through cooperation of the National Bureau of Standards, the members of the various committees appointed by the President of this Conference, manufacturers of devices, trade associations, industry, and the respective weights and measures officials who come from every cor'uer of our land to attend this Conference. In faimess to all concerned we must proceed with extreme caution in rendering our decision as to the best method of sale. A careful study must be made of existing conditions. We should also endeavor to anticipate the future. It is very apparent this business has become stabilized and will increase from time to time rather than diminish. All interests would be better served if uniform methods of sale, laws, or regulations could be adopted. Confusion is bad enough at the present time; it would only add to the confusion if each jurisdiction adopted its own method.

Ample time remains in this Conference to give serious thought to the many indexes used on volume meters. It is my firm conviction that most of the confusion can be eliminated if we go on record to recommend the abolishment of all indexes on volume meters immediately, except the cubic foot index, and put the recommendation into effect as soon as we return to our jurisdictions; certainly no harm can be done as the liquefied petroleum gas is measured in cubic feet to start 
with, then converted. In jurisdictions where type approval is required for these devices before they can be sold or used the solution is simple; approval could be refused, and where approval has been issued pending the adoption of standard methods same can be recalled. You will recall I stated these meters can be furnished either in a circular-read or straight-read type. It is my personal opinion the straight-read type will be more popular and serve the consumers' interest best, because it is the simplest to read.

Every day newspapers throughout the nation are furnishing news items of crime that is prevalent everywhere; editorials are clamoring for its solution; authorities are working feverishly to abolish it; critics everywhere are voicing opinions as to its cause. These opinions invariably differ except in cases of crimes committed by the youtl of our country. It seems to be the general opinion, that the cause of crime committed by youth can be traced to "Youthful Delinquency" which is aided aud abetted by persons of maturity who neglected to take the proper and necessary precantions of caring for the problem child.

As I stated in the beginning, we have a problem child on our hands. It is our obligation to approach this problem with the same enthusiasm and vigor which enabled us to rectify to the satisfaction of all interested parties the many other problems brought to our attention. This is a record to be proud of and we are entitled to boast of these many achievements. Our problem child is now growing, becoming mole confused as time passes.

Realizing our position, this problem can be solved quickly and satisfactorily. By working together, by giving our usual cooperation to all interested parties, and in return receiving the benefit of an exchange of ideas, we will avoid the aiding and abetting of "Youthful Delinquency" and add another accomplishment to our proud record.

WVe are gathered in the Conference to exchange ideas with each other and discuss the problems that confront us each day in our respective jurisdictions. Let us be helpful to each other, give the knowledge and results of our experiences to each other, especially to new officials who are attending the Conference for the first time. I will always cherish the fond remenbrances of the first Conference I attended ten year's ago as a new official. With sincerity it gives me great pleasure to admit that the knowledge I received from the speakers and experienced officials was equivalent to a few year's of research on my own initiative. Let all our criticisms be constructive for undoubtedly our intentions are good.

Permit me to extend to you my sincere good wishes for continued success in this noble field of endeavor.

\section{PROBLEMS ENCOUNTERED IN TESTING METERED SYSTEMS-BY CHARLES MORRIS FULLER, SEALER OF WEIGHTS AND MEASURES, COUNTY OF LOS ANGELES, CALIF.}

In previous papers delivered at the National Conferences in 1940 and 1941, I discussed "Contemplated Methods of Testing Meters Used in the Measurement and Sale of Liquefied Petroleum Gas", and "Testing Liquefied Petroleum Gas Meter Systems by the Gravimetric Method". Since that time, we have had a lot of experience-some of it puzzling, some of it exasperating, but all of it adding to our practical 
knowledge of the subject. This is to be a talk about some of the problems ellcountered, with the thought that it will be useful in eliminating a lot of headaches when you are confronted with these questions in the field.

In the first place, don't assign a deputy to this branch of the service who is inclined to be at all absent-minded or careless-unless you are anxious to get rid of him. For if gasoline is dangerous, this product is dynamite! In case of leakage or spillage, its vapor is heavy and clings to the ground, requiring only a spark to cause a shattering explosion that is devastating and often fatal. Handled with proper care and respect, it is a fuel of outstanding efficiency and value.

It is likely to be something of a shock when a Sealer of Weights and Measures approaches his first job of calibrating an L. P. G. tank truck. It does not have some of the attributes of the well-behaved vehicle tank to which he is accustomed; there are no centrally located domes on top; in place of these, he finds valves, gages, and fixed outage tubes which take the place of capacity indicators.

Calibrating these tanks is a time-consuming job. The normal gravity discharge rate from our testing outfit in Los Angeles, through 3 -inch outlets, is approximately 80 gallons per minute in filling ordinary gasoline tank trucks; but we consider ourselves lucky in approaching 20 gallons per minute when gaging an L. P. G. tank. The reason is this: Gasoline tanks have large fill openings that do not retard the flow of water from the test tanks. In the case of L. P. G. tanks, the water enters through a bottom valve and fill pipe, usually not exceoding 2 inches in diameter. Only very small air vents are provided, about $1 / 4$ inch in diameter, thus causing slight air pressures to develop and slowing down the rate of fill. Fire Prevention Bureaus and Industrial Safety Departments in California have frowned on any suggestions of providing manholes or larger fill openings in the top shell of these tanks because of the greater hazard of possible vapor leaks.

Referring again to the familiar gasoline vehicle tanks, we find these fitted with large fill openings, and within these openings are indicators which are plainly visible and which clearly, distinctly and unmistakably show the height to which the compartment must be filled to contain the marked capacity. The L. P. G. tank is a closed vessel and there is no visible means of indicating the capacity level. This was the definite problem that confronted us when we first started gaging them, some 12 or 14 years ago.

To answer this need, a slip tube indicator was developed. It consisted of a small, vertical tube within a friction fitting or packing gland, with a valve at the top of the tube. By sliding the tube lower or higher in the tank, the liquid level could be ascertained, as the pressure of the gas within the tank would blow the liquid through the valve at the top of the tube in the form of a white cloud as soon as the surface of the liquid reached the opening of the tube. We never recognized or certified these tubes for capacities at different depths throughout the tank, because this could not be done within the range of reasonable tolerances. We would certify to two capacity levels if the tank were constructed to stand the additional pressure and used to handle propane as well as butane. 
The slip tubes were marked in this manner: The tank was filled with water to the calculated inmage level. The depth of liquid from the shoulder of the packing gland was ascertained, and this distance in inches and fractions was filed as a ring on the slip tube. The constant development of vapor leaks in the packing gland, however, made this method unsatisfactory. There was also no positive means of sealin $g$ for the prevention of fraud. Slip tubes could be substituted.

The rotary gage was never recomnized as an accurate indicator of measure. It serves a purpose and tanks are equipped with them to indicate approximate liquid level, and also that the tank is pumped or drained dry.

Next appeared the much more satisfactory fixed outage tube. Essentially it is a small tube welded in a vertical position to a cross bar attached to the inside shell of the tank and midway between the ends of the tank. (Fig. 1.) The inlet end is cut off at the height that defines the filling point. 'The outlet end emerges through the bottom of a protective well, welded in the side of the tank, somewhat below the inlet end to facilitate rapid drainage, and is equipped with a valve through which vapor will vent until the liquid level reaches the top of the indicator tube. When calibrating a tank equipped in this manner, the fill valve should be partially closed as the capacity level is approached, so that the liquid level will not rise above the inlet of the tube before the liquid has a chance to appear at the valve of the tube. For this reason, the length of the tube should be as short as possible.

While the fixed tube overcame some of the faults of the slip tube, we ran into mechanical difficulties of installation. As the result of vibration and road stresses, the cross bar to which the tube was welded would break loose from the shell of the tank, or the tube would part company with the cross bar-serious draw-backs indeed.

To overcome his troubles along these lines, one enterprising fabricator welded the fixed tube to the shell of the tank and then let it extend down from the top of the shell to the correct innage point or level. (Fig. 2.) While this solved his problem, he did not give any consideration to calibration procedure nor did he even inform us of the change. Naturally, when we calibrated the tank, there was hardly any expansion space left, because not enough pressure was developed to force the water up and out of the tube. Our calibration data did not agree with the calculaterl capacity of the tank. IVe contacted the fabricator and the cause of the error was revealed.

After some consideration, we decided to try out a simple type of aspirator, or filter pump, to create a suction. 'This was used in combination with the following arrangement for the purpose of calibrating a vehicle tank that had two fixed tubes for the purpose of indicating the fill levels of either" propane or butane. A " $U$ " tube was fashioned from small glass tubing. Another piece of glass tubing was joined to the bottom of the "U" tube, and this was connected to the aspirator by means of rubber tubing. The two legs of the "U" tube were connected by rubber tubing to the outlet valves of the fixed indicator tubes of the vehicle tank. Clamps applied to the rubber tubing made it possible to shut off either of the tubes, so that only one would be in operation at a time. (Fig. 3.)

With the aspirator functioning, a suction is created within the tube connected to it. 'This causes water to appear immediately in the glass 


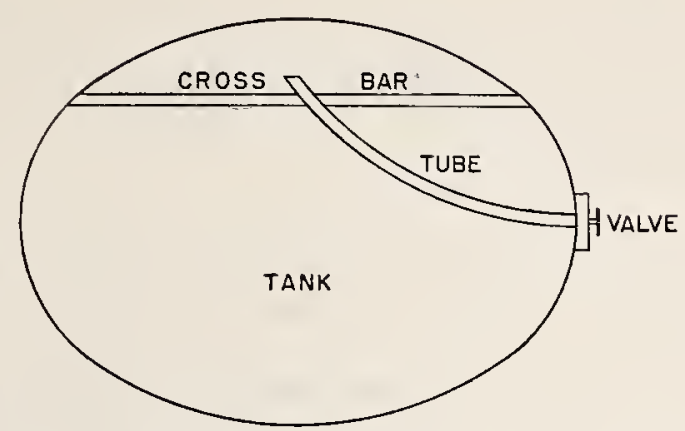

Figure 1. Fixed outage tube, welded to eross bar.

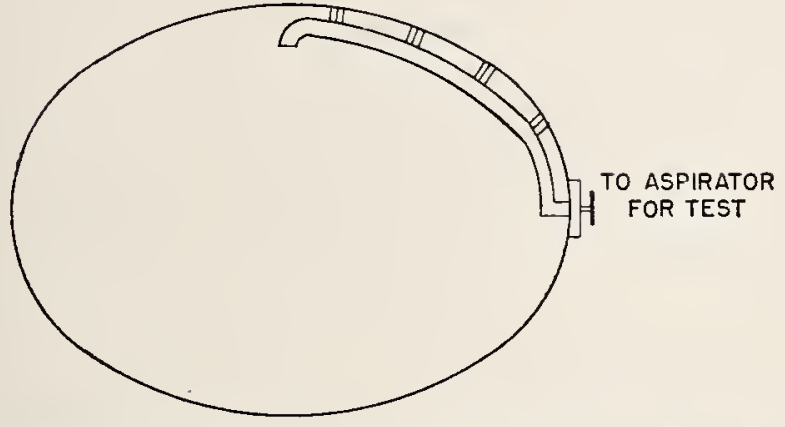

Figure 2. Fixed outage tube, welded to tank shell.

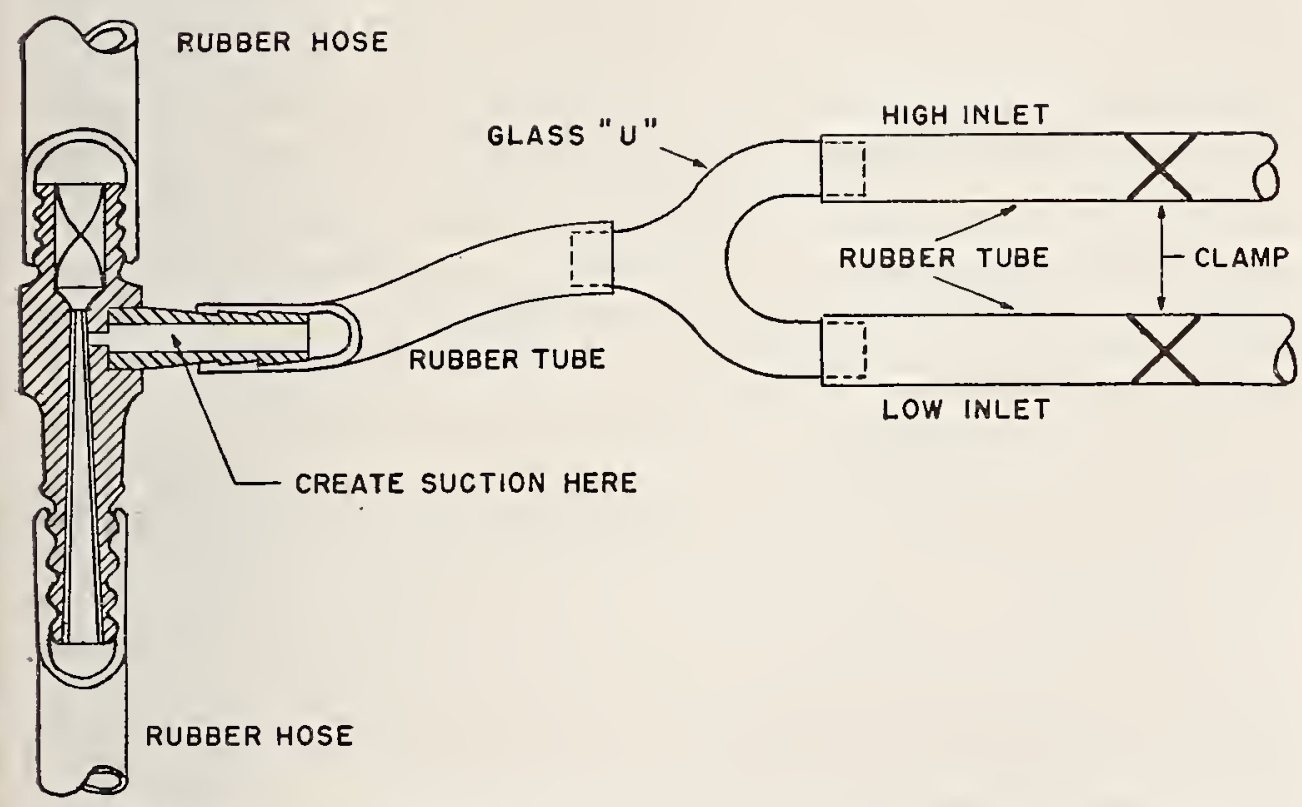

FIGURe 3. Aspirator-and-U-tube indicator, for use vith fixed indicator tubes. 
"U" tube as soon as the level in the vehicle tank rises to the opening of the fixed indicator tube, and the inspector quickly shuts off the flow of water from his calibration tank. Calibration within a much closer tolerance is made possible by this equipment. When filling the tank with liquefied petroleum gas, the increased vapor pressure eliminates any need for an aspirator.

Another problem, pertaining to the proper draining of the velicle tank, was solved through the cooperation of the Bureau of Industrial Safety and Fire Prevention. Safety Codes require some automatic means to stop the flow of liquid if an accident were to shear off the piping or valves from the tank. One device satisfying this requirement is known as an excess flow check valve, having an over-all length of about six inclies. The actuating spring on this valve is set at a tension so that during a normal rate of flow the valve is held in an open position. If anything happened so that the piping and valves were broken or sheared off, the resulting faster flow would cause the valve to automatically close. For greater protection, the Code requires this valve to be placed within the tank. This causes it to extend about 4 inches above the bottom and naturally, quite a few gallons of liquid are entrapped. At our suggestion, they allowed the fabricators to weld a small well to the bottom of the tank, into which the valve was. fitted flush with the bottom. This permitted complete drainage and did not in any manner weaken the structure of the tank.

Another problem that has developed and is still in the discussion stage, pertains to what is known as the dip discharge pipe. In order to eliminate a lot of piping on L. P. G. tank trailers, and to shorten lines when connecting to the discharge pump located on the truck, the builders conceived the idea of discharging through a dip pipe that emerges from the front end of the tank, about 15 inches above the bottom. Recent tests slowed that some 15 gallons were entrained in a 3,000 -gallon tank using this type of outlet which, of course, is beyond the realm of reasonable tolerance. Whether or not a pump could pull all of the liquid out of the tank if the dip tube ended in a well, instead of about an inch above the bottom of the tank, is a debtable question. We expect to have available a tank of this type in the near future, and will conduct tests to settle the question. We do not favor this type of construction because if a hole ever developed in the weld of the tube, suction would be broken at that point and considerable liquid would be trapped in the tank. Also, it detracts from the efficiency of the pump. The pump cannot deliver as many gallons when it is sucking as it can when there is a gravity head.

A gleat deal of thought and attention has been given by our Department to maintaining the inherent accuracy of meters dispensing L. P. G. by also giving careful consideration to the installation and piping lay-out, including proper provision for vapor elimination. Inasmuch as I. P. G. metering systems always operate under pressures in excess of atmospheric pressure, air cannot enter the system and that ceases to be a problem; but wherever and whenever a pressure drop occurs within the system, gas bubbles form and these must be completely eliminated. Otherwise the meter will over-register and short measure will result.

So far, the practice has been to adapt gasoline meters to L. P. G. use by placing the measuring chambers or mechanism inside of more 
substantial cases that will withstand the additional pressure. In line with this adaptation idea, the conventional type of air eliminator was first tried out but the heavy operating pressure would collapse the float, making it inoperative. While this problem appeared formidable, it was solved very simply. As many of you may recall, some of the early models of gasoline service-station pumps were equipped with air eliminators that did not have float mechanisms. In place of this, the top of the air chamber had a small outlet that was connected back to the underground storage tank by means of a $1 / 4$-inch pipe. While the pump was operating a constant small stream of gasoline would flow from the air chamber to the storage tank, and with it would go any air or gas bubbles that might have accumulated in the top of the chamber. The same arrangement was tried with L. P. G. meters and was found to operate so effectively that all meter units are now equipped in that manner.

I must quickly add, however, that as a sole means of vapor elimination, this method would prove inadequate if some means were not provided to keep downstream pressure, at all times, equal or nearly equal to the pressure within the meter and intake line. It can be readily understood that if the downstream pressure should become reduced, so much L. P. G. within the meter and lines would vaporize that the capacity of the vapor return line would be exceeded, the rest of the vapor within the meter would rush through causing the meter to spin, and short measure would result.

We speak of reduced downstream pressure. You may ask what causes that? Well, if L. P. G. was a homogenous product, we would not have such a pressure problem. But it is composed of components or hydrocarbon compounds known as Methane, Ethane, Propane, Butane, Pentane, and Hexane. As we are more familiar with Propane and Butane, although we seldom encounter them in a pure state now, I will give their vapor pressures at $80^{\circ} \mathrm{F}$ : Propane 128 pounds, Butane 22.9 pounds. If a tank having previously contained butane, and now filled with butane vapor, were to be filled with propane by means of a meter, a pressure drop would occur on the downstream side of the meter and would continue until the butane tank received enough of the propane gas to equalize the pressure.

By what means do we overcome this problem? Several devices are now in use that answer the question in varying degrees. The first device I will describe is known as a differential-pressure or diaphragm back-pressure valve (Fig. 4). It is placed in the line between the meter and the shut-off valve. Essentially the valve comprises, besides the seat, a diaphragm, a spring above the diaphragm which exerts pressure to close the valve, and a small inlet to space above the diaphragm. This inlet is connected to a vapor return line to the supply tank, and by this means the vapor pressure in the supply tank is exerted on the diaphragm of the valve. The spring tension is normally set at 10 pounds.

Now, even though we open the discharge valve, nothing will happen, no flow will take place, until we start the pump and build up enough pressure (which in this case, as illustrated above, will be 128 pounds vapor plus 10 pounds spring pressure or 138 pounds) before the valve will open. Thus no pressure drop can occur because we are always assured of a 10-pound differential. No matter what pressure may be built up within the supply tank as a result of higher temperatures or 


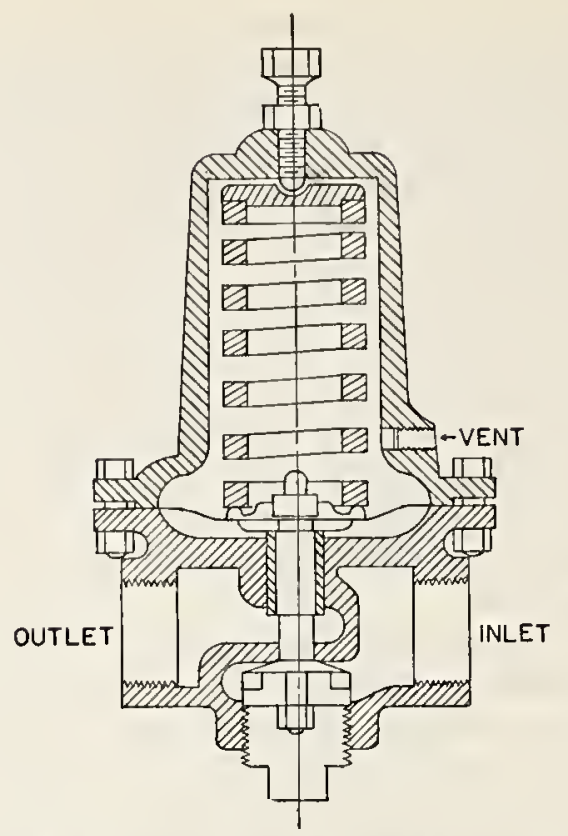

Figure 4. Differential-pressure or diaphiagm back-pressure valve.

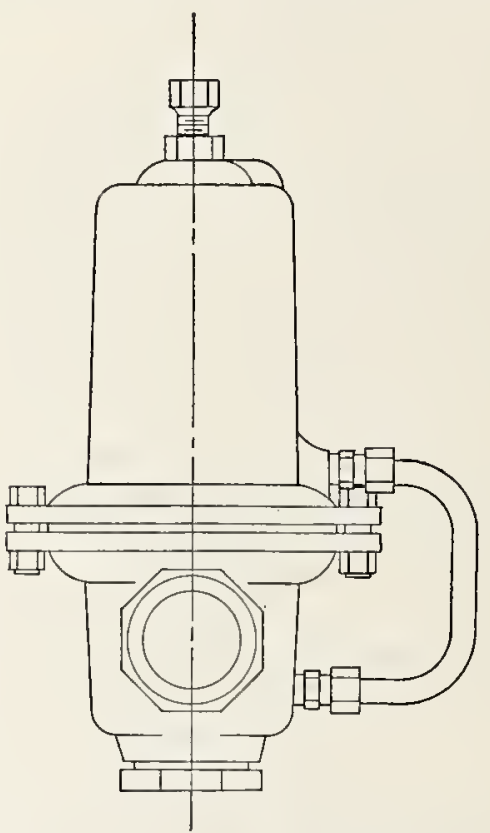

Figure 5. Differential valte assembly.

change of product, those same pressures will always be exerted above the diaphragm. The great advantage to be gained by the use of this valve is that a nominal 10-pound differential pressure exerted by the spring will prevent the formation of any vapor in the line; and the pump, because it has to overcome only a small differential pressure, will operate more efficiently.

Another type or model, manufactured by the same company as a back-pressure valve for oil lines (Fig. 5), has been tried in L. P. G. 
systems, although the company does not recommend it for this use. The difference between this model and the one just described is that instead of a vapor inlet, a "U" tube is incorporated in the construction of the valve. One leg of the tube enters below and the other above the diaphragm. The valve has not proved satisfactory because it exerts a back pressure equivalent to the spring tension plus the pressure in the discharge line. The point at which this valve will pass liquid is not adjusted to the vapor pressure of the liquid in the meter or supply tank, therefore it is possible for a pressure drop to occur.

The other type valve in use is simply a spring-loaded check valve, and the spring pressure is usually set at 15 pounds by the manufacturer. If tanks are to be filled with comparable hydrocarbon compounds, the above type will function quite satisfactorily, but if compounds such as butane and propane are used as mentioned in the previous example, the question again arises about the ability of the valve to adjust itself to the vapor pressure in the supply tank. Under certain conditions, pressure drops will occur with the subsequent bad result of the meter spimning, and over-registration or short measure. If the tension of the spring in the valve is increased to provide enough back pressure to prevent vaporization of the liquid, then an excessive load is placed on the pump and motor which will slow up the rate of flow, causing possible inaccuracies and abnormal wear.

A common fault with many metered installations is the failure to provide adequate pumping capacity to operate the meter at its proper rate of flow. One particular installation was well engineered in every other way, but the average rate of operation was about 18 gallons per minute, instead of the 25 gallons or more which the 2-inch meters neeeded for normal operation. As a result, about 2 percent of the liquid bypassed the meter. The mistake should not be made of using too-large meters for the rest of the system.

At another installation, we were unable to get any consistent rate of flow through the meter. The flow would build up and then slow down. On inspection we found two pumps in the line, in series. 'The first pump had the task of lifting the liquid about seven feet, and while struggling to perform this feat, the second pump would pull the liquid away faster than the first pump could deliver it, thereby causing vapor locks, and the slow and erratic pumping performance. The best pumping systems are those where there is practically no lift.

Since L. P. G. is much lighter in viscosity than gasoline, slippage clearances in meters adapted to this service must be reduced to a minimum, otherwise, at slower rates of flow, the meter will under-register, giving over measure.

In the design of metering systems, the entire system should be considered as a complete or integral unit. When purchasing a pump, data should be obtained regarding the number of gallons per minute it will deliver under the conditions of installation, and then a meter should be purchased of a size that will maintain a reasonable accuracy curve within the rate of flow the pump will deliver, thereby reducing the danger of slippage.

Another frequent cause of slippage is dirt or foreign matter as the result of inadequate screens or even no screen at all for the protection of the meter. At least an 80-mesh screen, adjacent to the meter, should be used. These screens should be cleaned even more frequently than 
those in gasoline service because of the closer clearances in L. P. G. meter's.

Within the limited scope of this paper, I have endeavored to state in plain language some of the common problems which we have encountered in testing I. P. G. equipment. While you may not, as yet, have been called on for this type of inspection, be assured that your time is coming, for the production, sale, and use of liquefied petroleum gas is increasing by leaps and bounds. A generation ago, it was pretty much a waste product in the refining of gasoline-considered a nuisance by the companies. Last year, over $2 \frac{1}{2}$ billion gallons were marketed-an increase of 29.5 per cent over the volume sold the preceding year. It is up to us, gentlemen, as weights and measures officials, to keep up with this progress.

SUPERVISION OVER SALES-BY H. L. SHANKLE, CHIEF, GASOLINE AND OIL INSPECTION DIVISION, STATE OF NORTH CAROLINA

In a preceding paper entitled "Units of Measurement" Mr. Blickley has pointed out the various methods used for the measurement of $\mathrm{L} P$ Gas. It is not the purpose of this paper to discuss the relative merits of any particular method of measurement, but rather to point out those activities of the weights and measures officer that will tend to minimize short weight or measure in the sale of this commodity as much as possible.

Since the sale of $\mathrm{L}, \mathrm{P}$ Gas by weight is the most widely used method of sale, let us consider this case first. In such instances, the $\mathrm{L}$ P Gas is delivered to the consumer in "bottles" or cylinders, which usually contain 100 pounds of L P Gas. The weighing in connection with this method of sale is done at the filling plant at the time the "bottle" or cylinder is filled. The cylinder is placed on a platform type of scale and connected to the filling line by means of a flexible hose. The tare weight of the cylinder is determined and $\mathrm{L}$ P Gas is then run into the cylinder until the desired weight of gas has been introduced. Usually these cylinders hold 100 pounds of gas and have an empty weight of 90 to 100 pounds. If the weight of the gas to be known with an accuracy of $\pm 1 / 2$ percent, it will require knowing the tare and gross weights within $\pm 1 / 2$ pound. For the protection of the consumer, the following is recommended:

1. 'That the tare weight of the cylinder' be permanently stamped on the cylinder in a conspicuons place.

2. That the platform scales at the filling plant be equipped with an electricallyoperated mercury switch and valve to automatically cut off flow of liquid $L$ P Gas when the desiled quantity of gas has beel put in the cylinder. (The use of this device will eliminate a very substantial portion of the human errors in weighing. In addition, it will prevent the over-filling of cylinder's, thereby eliminating the danger of rupture of the cylinder by excess pressure due to lack of improper gas space above the liquid.)

3. That the cylinder be sealed at the filling plant with a lead seal and that the cylinder be delivered to the consumer sealed. (The delivery of sealed cylinders would tend to eliminate much of the doubt that now exists in the mind of the consumer as to the quantity of gas in the cylinder.)

4. That the weights and measures officer not only test the scales at the filling plant but also make spot checks of the tare weights of empty cylinders and the gross weights of filled cylinders at filling plants.

5. That the practice of replacing a partially used cylinder of gas with a full cylinder and credit allowance for the unused portion be prohibited except in 
cases where the actual weighing of the cylinder to determine the amount of unused gas is done on acceptable portable scales in the presence of the consumer. (This practice has caused a majority of the complaints from consumers as the weighing of partially used cylinder's is, in most cases, done at the distributor's plant at the close of each day. No doobt; many consumers have had just cause for complaint.)

The second method of sale of L P Gas is one that is used to a considerable extent in our State and consists of the measurement of the gas in the vapor state by use of a gas meter. In this case, the customer is billed periodically for the gas consumed on the basis of meter readings. For the protection of the consumer, the following is recommended :

1. That all gas meters be submitted to the weights and measures officer for inspection and sealing prior to installation.

2 . That all gas meters in selvice be removed at regular intervals for reinspection and sealing.

3. That the basis of measurement be solely in terms of cubic feet of gas consumed as indicated by the gas meter. (The use of gas meters with the many billing scales such as decitherms, pounds, B. T. U.'s, etc., bas resulted in much confusion in the minds of the consumers. The report of the Committee on Methods of Sale of Commodities, adopted by the 1947 National Conference reads as follows: "Liquefied Gases (Butane, Propane, etc.) for household use: Should be metered and sold by cubic feet." Rigid observance of the recommendation of this Conference will materially aid in the elimination of the confusion that now exists.)

The third method of sale of $\mathrm{L}$ P Gas consists of the measurement by volume of liquid delivered. Measurement of gallons delivered should be made by use of a rotary meter of the type used in the measurement of delivery of fuel oil for domestic heating purposes. L P Gas meters of this type are available from several manufacturers and can be supplied with ticket printers. Such meters have been tested and found to deliver L P Gas in the liquid state with a high degree of accuracy. A special testing unit for this purpose was described by Mr. Fuller in the 1940 Conference Report. Similar units, with modifications, are now used in California, Florida, and North Carolina. The unit described by Mr. Fuller in the 1940 Conference Report, as well as the units used by the States of California and North Carolina, are the gravimetric type, while the unit used by the State of Florida is the volumetric type. The gravimetric method of testing such meters has thus far proved to be more satisfactory as it is least susceptible to uncontrollable errors in testing. In such tests, it is recommended that the use of the vapor return line be eliminated except when pumping out the test measure in preparation for the next test.

The unit that is used in the State of North Carolina to test I P Gas meters is available for inspection by members of this Conference. The place of this inspection will be announced later by the Conference Secretary.

The fourth and last method of measuring sales of L P Gas is by tank gaging. Your speaker has had very little experience with this method of measuring sales of L P Gas, as this method is not used to any great extent in North Carolina. On the basis of such limited experience, it does not appear that the accuracy of measurement is all that can be desired. Its use as a means of measuring quantities delivered is, therefore, questionable. 
From a paper presented to the 1940 Conference by Mr. H. S. Bean, we quote two paragraphs that summarize the best available information on this subject at the present time:

The volume of liquid gas in the tank is measured both before and after the customer's tank is filled. The type of gage generally used for this purpose is known as a slip-tube. Essentially it is a small smooth-walled tube placed to slide vertically through a packing gland into or ont of the tank, and equipped with a valve at the top. To determine the position of the liquid surface in the tank, the valve at the top of the tube is opened and the tube is lowered into or withdrawn from the tank until liquid first appears or disappears at the tol. Then, by measuring between the top of the tube and a reference point with a suitable scale, the depth of liquid in the tank or its volume is determined. In some cases whele this method is used the quantity of fuel delivered to a customer is determined from the mean of the measurements made on the customer's tank and the truck tank.

The chief advantage of this method is its extreme simplicity and low cost. This Bureau has had no experience with a gage of this type so we have no firsthand knowledge of its relative accuracy, nor have we received the results of any ohservations that mas have been made by others. It is evident, however, that the accuracy of the measurements will depend upon the size and position of the tank and in the case of horizontal cylindrical tanks, upon the position of the liquid surface in the tank. For the purposes of comparison with other methods let us assume that the position of the liquid surface can be established to within $1 / 4$ inch. Then, assume a horizontal cyliudlical tank of 30 inches inside diameter. If the true depth of the liquid were 2 inches, the $1 / 1$-inch errol will represent an error of approximately 18.6 percent in the volume of the liquid. If the tank is half full, the error will be 2 percent, while if filled to within 2 inches from the top, the error will be only 0.6 percent.

Four methods of measuring the quantity of L P Gas delivered have been listed and suggested activities of the weights and measures officer with respect to the three most common methods of sale have been pointed ont. Prevention of an offense rather than apprehension of the defendant is by far the better administration of the law. This is the general aim of the weights and measures officer. Rigid enforcement of these suggestions should aid materially in the realization of this general aim.

TESTING EQUIPMENT FOR LARGE-CAPACITY METERS

\section{By Paul Renfrew, Chief Engineer, Ratph N. Brodie Co., Inc. ${ }^{4}$}

It was only a few year's ago when oil companies considered 150 or 200 gallons per minute a good rate of flow for truck loading. Occasionally someone wanted more than 300 G. P. M. Today 400 to 450 G. P. M. installations are common, with a good many operating at 500 to 600 G. P. M., and attempts being made to operate at speeds even higher. The same trend has taken place with respect to automotive equipment. 'The tendency has been steadily toward larger units and faster unloading. To take full advantage of these increased speeds, the size of filling station storage has been enlarged with the result that the volume of the average filling-station dump has been materially increased to the point where many will take a load of 5,000 gallons or more.

It is obvions then that the calibration equipment that was practical for proving those early meter installations is not adequate for the

${ }^{4}$ In the absence of $M I^{2}$. Renfrew, this paper was presented to the Conference by $\mathbf{M r}$. Don W. Kingsley, Ralph N. Brodie Co., Inc. 
present-day high-speed units. This brings us to our subject, "Testing Equipment for Large-Capacity Meters."

Before entering into a discussion of the equipment proper, we must ask ourselves, "What kind of operation and data do we expect to obtain from the use of this equipment?" It would seem that we could all agree that from the use of it we should be able to determine the performance of the meter and its accessory equipment:

1. As operated in normal everyday use.

2. As operated under such special conditions as might be required.

From this it is logical to conclude that the testing facilities should permit procedure which duplicates or at least approaches actual operating conditions. And while we are considering testing procedure and design of the equipment, we must keep in mind those physical characteristics of the liquids being measured which influence the accuracy of our testing. For instance the rate of evaporation of volatile liquids is an important factor, as are viscosity and surface tension which control the film adherence to the walls of the tank and influence the time required to drain it. In other words, the test data must truly represent the performance of the meter and its accessories. We must have a minimum of human error and guess work involved in making the test.

This being a National Conference, we should consider the subject from the standpoint of a weights and measures juriscliction. On this basis, testing equipment for loading rack meters should have complete mobility because the equipment has to go to the loading rack. To approximate filling-station conditions for testing gravity truck meters we should have a tank in a pit which means that the truck has to come to the test equipment.

Now the heart of the testing equipment is the calibrated tank and, for purposes of clarity we will refer to it as the prover tank. First, let us decide what volume the tank should hold. We believe that all will agree that the ideal prover tank for either loading rack or gravity truck meters would be one with a holding capacity equal to the volume of the average delivery made in everyday operation. The practical unit is, of course, a compromise with the ideal. Experience has shown that prover-tank capacity should in no case be less than 1 minute's delivery through the meter and preferably one and one-half to two times this amount. These proportions have been adopted by the National Conference, by the API-ASME, and are the accepted practice with the operators who design and make their own testing equipment.

The importance of ample-size equipment for testing high-capacity loading-rack meter's is best illustrated by considering just one or two of the problems involved when attempting to use a 100-gallon prover for testing a 500 G. P. M. meter. First, even in testing with a light liquid-like gasoline, the periods consumed in getting up to speed and topping off will probably deliver more than the 100 gallons contained in the tank. 'The inside diameter of the upper' neck on this size tank is not likely to be much larger than the under-surface drop tube used on a $500 \mathrm{G}$. P. M. loading arm. With this combination we either have to reduce the flow to a trickle, or stop the flow several times, as the liquid enters the upper neck of the tank. If the liquid had bad foaming characteristics, we probably couldn't even approach the maximum 
speed of the system during the entire delivery of the 100 gallons. The delivery would all have to be made at a very low rate of flow.

Compare the above with regular loading operations when 90 percent or more of the tank contents are delivered at the maximum speed of 500 G. P. M., only a very small percent of the delivery being consumed by the period of starting and topping off.

In designing the stationary testing equipment we must keep in mind the very definite limitations which are placed upon tank-truck meters. The space available limits the size and proportions. Dead weight must be held to a minimum in automotive equipment. Contamination requirements limit the holding capacity of the meter and its accessories. Yet, with all of these limitations the air eliminator of the truck-tank meter is required to accomplish a difficult job of air separation and elimination. Furthermore, an inaccuracy from this source outside the limits for a small prover tank might very easily be well within the limits for a tank with a holding capacity approaching the volume of the average filling station dump. In other words, any inaccuracy resulting from an air condition is a constant irrespective of the size of the prover tank employed.

It is, therefore, obvious that testing equipment for gravity truck meters should have proportions which will reflect this inaccuracy its true relationship with actual operating conditions. It would seem from these considerations that the specification for the volume of a prover as previously set down is a perfectly reasonable compromise. A volume equal to one minute's operation of the meter is the absolute minimum we should attempt to use.

The size of the top calibrated neck is an important factor if testing is to approximate actual operating conditions with respect to rates of flow. If the neck is too small it requires throttling to very slow flows as the liquid level approaches and enters the neck. This is especially true on oils which foam badly. In fact, we can recall a very fine 1,000 gallon plover tank which was entirely impractical because of a calibrated neck made from 4-inch pipe.

This specification should permit topping off during a test to approximate the actual loading conditions in filling a truck. In the testing of tank truck meters it should allow a maximum rate of flow up to the point of closing the outlet valve. Experience and actual practice have indicated that a diameter which gives a height of $5 / 8$ inch for $1 / 10$ of 1 percent of the tank contents is a practical compromise. This will permit reading to a tolerance which equals one hundredth of 1 percent of the tank contents. As an example, this would be $11 \frac{1}{2}$ cubic inches or $1 / 16$ inch of height of liquid for a 500-gallon tank, the neck on which would approximate $93 / 4$ inch inside diameter.

Next, we come to the question of the height that the testing equipment should be. For loading-rack meters, it is obvious that it should approach that of a tank truck. In fact, this is a necessity with the type of loading arm which moves only in a horizontal plane if we are to avoid a long drop which might radically change the evaporation conditions. Furthermore, the loading arm must be kept full right up to the loading valve. The effects of air pockets on the discharge side of the meter are common knowledge. 'The volume of the top neck above the zero point must be sufficient to permit the same rate of flow as is used in topping off a truck tank. 
When testing gravity fruck meters it is important that the negative head and the evaporation conditions be the same as those encountered when delivering to a filling station. This means, that we must have a depth of pit and a height of tank which will produce negative head conditions approximating those found in a filling station. We have previously accepted a tank in a pit as the necessary equipment for testing gravity truck meters. Some of you may question a prover in a pit because of the hazard from gasoline fumes settling to the low point. It is not difficult to rentilate a pit, nor is it costly.

If we are to get proper drainage and protection against air pockets we must give careful consideration to the shape of the tank as well as the slope of the top and bottom heads. The mobile unit for testing large loading rack meters is usually used for quite a range of products, varying in viscosity from motor fuels to the heavier fuel oils. Also, the shape and proportions of the mobile prover tank are influenced by the chassis on which it is mounted. Nevertheless, the tank must drain properly and trap no air when filled.

The most common unit for testing the large truck meters is the vertical cylindrical tank with tapered top and bottom heads. At the present time a great majority of the gravity truck meters being tested with this equipment are measuring gasoline. However, it would seem good business for future flexibility to have the slope of the top and bottom heads sufficient for use with products of higher viscosity. This fundamental requirement is very well set down in the API-ASME Positive Displacement Meter Code, from which we quote as follows:

The inside of the prover tank should be smooth and free of pockets where liquid or vapor may be trapped. Changes of cross section should be gradual and of steep enough slope so that as the tank is filled all gas bubbles will travel to the top of the tank and as the tank is emptied the liquid will drain quickly.

It is important that the draining of the prover tank be consistent. This means that the time required to do it must be reasonably constant. A 500-gallon test tank, in use at a certain bulk terminal, had something over 80 square feet of inner surface. It is obvious that any variation in the wetting of this amount of surface would materially affect test results.

It is also obvious from the above that the elapsed time between drainage and refilling the tank for the next test should be uniform. Any variation in the length of time the inner wetted surface is exposed to evaporation will affect the test results when using a volatile product, such as gasoline.

A prover unit for large meters must include a pump for returning the test liquid to storage. The suction piping of the pump should be installed so that the tank will drain quickly and sharply. For instance, a baffle over the outlet opening will help drainage by eliminating the vortex. The pump should not pick up air in any volume until the tank has completely emptied. This can be accomplished by proper design of suction piping.

One should be able to quickly and positively check the tank for completeness of drainage. The outlet valve may be so located that a visual check is sufficient. Some operators prefer, and in fact some 
conditions require, a bottom neck and gauge glass which provides a starting liquid level.

There should also be means for occasionally checking the tank outlet valve for leakage. Some types of valves will develop a leakage which is sufficiently constant that it might not be easily detected if the piping between the valve and the pump is rigid. For this reason, some prefer the hose with quick coupling which can be discomnected during filling. Two valves, with a pet cock in the connecting nipple, is preferred by others.

For complete control of the test, it is important to know if there is any expansion or contraction of the liquid as it flows into the prover tank. The temperature of the metal of the tank is also an important consideration. A tank exposed to direct sun on a hot summer day will hold a greater volume than it will on a cold winter day. This condition is aggravated if the tank is painted a heat-absorbing color. For instance, a tank calibrated to hold 500 gallons at 60 degrees will contain considerably more than 500 gallons if the temperature is 100 degrees. Furthermore, hot tank walls will increase the evaporation rate of volatile products, such as gasoline. Therefore, prover tanks should have properly located thermometer wells and be protected against the direct rays of the sum.

The gauge of metal, construction, and workmanship should be such that the tank will not change shape under normal use and with reasonable care. A prover tank should have a tight cover for protection against the elements during idle periods. Its mounting should induce no stresses which would result in a change of shape or volume.

The 15 minutes which have been allotted for this discussion made it necessary to confine our considerations to the open-top volumetrictype prover. It did not seem advisable to try to include any of the other methods as, for instance, the gravimetric or weight-type equipment, which is used when testing with very viscous liquids which adhere to the tank walls in such quantities as to make volumetric testing impractical. Neither have we attempted to design a specific tank. Instead, we have endeavored to outline some of the principal requirements and specifications which shonld be kept well in mind while planning or designing test equipment for high-capacity meters.

In planning a terminal where meters are to be used, we recommend that the prover be considered of the same importance as any other accessory necessary to satisfactory meter operation. We have found too often in our experience that when meters are installed the test measure is forgotten. In laying out a terminal today we are trying to have the prover considered the No. 1 item on the list of material.

We sincerely thank you for the opportunity of discussing this subject with you. It is one of utmost importance to all of us who are responsible for obtaining correct measurement.

A REPORT FROM THE NATIONAL SCALE MEN'S ASSOCIATION

By Wullam D. ClakK, Manager, Scale Department, Fairbanks, Morse and $C o$., and Past President, NSM A

You are holding your 'Thirty-fourth Annual Convention. The National Scale Men's Association has just held its Thirtieth Annual 
Convention. We have both been around for a long, long time. It is time we got better acquainted with the fundamental aims and objectives of the two organizations. There must be merit to any organization that can survive the wear and tear of thirty or more years of activity. In years past, it has been the custom to have the President or Secretary of the National Scale Men's Association submit a report on the activities of the Association. Since the President of our Association has been unable to attend, he has asked me as Past President to take this assignment.

Some of you are members of our Association, and no doubt, many who are not members know of the Association, its purposes, and some of its past activities; so I am not going to take your time to review what has been said before.

The last Report made to you outlined a new departure, the "Organization and Chartering of Ten Divisions of the National Scale Men's Association," and the purpose of this move was explained. This experiment has so far proved beneficial, and has given a much-needed impetus to the organization. We increased our membership by 65 new members last year, and our total membership is now in excess of 400. We chartered one new division, the "Pacific Northwest," last year, and one division withdrew from the National Association, although several of its members retained their membership in the national body.

A very successful annual meeting was held at Indianapolis in April this year. A number of papers both interesting and instructive were presented, and quite a few new members were added to our roster.

We appear on your program undẹr the subject, "Report from the National Scale Men's Association." We believe we are placed on this program not as a matter of courtesy, but because the membership of this Conference is really interested in the activities of our Association. So far as the activities of the Association are concerned, I can best report by saying "Read the last Report."

It seems timely that instead of appearing before your Conference with a report on generalities that have questionable value, there could be a much closer cooperation between the National Scale Men's Association and the National and State Bureaus of Weights and Measures. Therefore, I would like to digress somewhat and expose to you some future planning which the National Scale Men's Association would like to formulate for the general advancement of weights and measures work annong all classes and bodies of men interested in, and obtaining their livelihood in, that field of endeavor. So, with your permission, I will proceed on that basis.

The National Scale Men's Association is made up largely of mechanical, technical, manufacturing, and sales personnel, nearly all of whom are practical men in their chosen rocations. The State organizations are largely political; their function is mainly regulation, with power to enforce. The National Bureau is more of an advisory group which recommends, but which is without power to enforce its recommendations. Of our 400 members, comparatively few have the opportunity to attend the meetings of the various weights and measures bureaus, or the National Conference. And only those in attendance receive a copy of the proceedings. There is a wealth of information on all 
phases of weights and measures work and there are hundreds of our member's who would find valuable information in your reports. If you were to supply copies of your reports to the National Scale Men's Association, we would see to it that copies were mailed to all our member's. So why not distribute this informative material where it would do a world of good in advancing your cause and our's?

An instance of State cooperation may well be defined by the action of the State of Indiana. 'The State of Indiana, in their periodical meetings, include a question-and-answer program on weights and measures problems, information of great value to scale men of all classes. 'Through the cooperation of the Indiana Weights and Measures Department, this material is placed in the hands of members of the National Scale Men's Association.

As another instance Mr. Ralph Smith, whom you all know, prepared an excellent paper on equipment for the testing of large-capacity scales (NBS Letter Circular LC920); this material has also been made available to our members, and distributed accordingly.

Many of our members know little of weights and measures laws, regulations, and specification requirements pertaining to weighing equipment in the several States, counties, and cities in whicl they operate. On the other hand, it is very probable that few of the persomel of the various weights and measures bureaus know a great deal about weighing devices, their installation, and their practical use and operation.

I believe the various weights and measures bureaus, National, State, county, and city, have information that our members should have. And I believe that our organization or its member's have information that the members of the weights and measures bureaus should have. The trouble seems to be that few know what is available, and where or how to get it. Of course, it will be possible for the heads of the weights and measures bureaus to obtain information on the mechanical construction of weighing equipment from the manufacturers, for such distribution to their personnel as may be necessary; but there are problems in practical operation that can only be answered by men of experience. It would therefore seem to me that by some plan of closer cooperation, this information could be obtained through the National Scale Men's Association. Likewise, the heads of the weights and measures bureaus could provide the Secretary of the National Scale Men's Association with copies of any specific laws, regulations, and specifications of their respective governments, and the Secretary in turn would distribute such information to the members of our organization.

The Secretary of the National Scale Men's Association could also provide the heads of the weights and measures bureaus with copies of papers pertaining to weights and measures subjects that we felt would be of value to weights and measures men. Problems encountered by weights and measures men could be submitted to our Association for discussion at our divisional meetings, or, if necessary, could be submitted to some member of the National Scale Men's Association who might be capable of giving a practical answer.

In conclusion, I believe that the interests of the National and other bureaus of weights and measures are sufficiently parallel and related to the functions of the National Scale Men's Association to warrant 
closei cooperation if greater achievements from the efforts of these organizations are to be realized on a mational scale. We are attempting a setter job of disseminating information not only to our own member's on National and State activities, but in turn, offering what help we can give to all other fields of activity in weights and measures work. 'The thoughts I hope to leave with you are not too difficult of accomplishment. I, therefore, request and earnestly solicit the cooperation of the many weights and measures officials present liere today, by asking them to carry these suggestions home with them for serious consideration. All we need is the starting power, and from that point on, the program will carry itself along on its merits.

(At this point, unon the suggestion of Mr. J. George Hugel, Sr., a representative of John Chatillon and Sons, tie Conference stood in silence for fifteen seconds in memory of George E. Cliatillon who passed away on March 10, 1949.)

(At this point the Secretary repeated the names of those appointed to the Committee on Resolutions and the Committee on Nominations, and at the request of the chairmen of these committees, announced open meetings of each committee to be held for the purpose of receiving suggestions from the Conference membership. The Secretary also anuounced receipt of a letter from Mrs. J. W. Saybolt extending her greetings to the Conference. The Secretary also announced, by request, that a "trade party," sponsored by the equipment manufacturers, would be held on Thursday evening from 9 o'clock to 1 o'clock, to which all members and guests of the National Conference were invited.)

\section{OPEN FORUM}

The Chamaran. Delegates and guests are now invited to bring up for discussion any weights and measures questions not formally scheduled on the Conference program.

Mr. R. E. MEEk. I was recently privileged to read an exchange of correspondence between $\mathrm{Mr}$. Joseph Giuliano, former Superintendent of Weights and Measures of New Jersey, and a New Jersey concern relative to reconversion of gasoline pumps. This was rely interesting to me and I think wonld be of interest to many other's at this Conference. I understand that $\mathrm{Nr}$. Roger's is well informed on what took place, and I should like him to tell us about it.

Mr. Rogers. This is a matter which we have more or less disposed of in New Jersey. A movement started to "convert" gasoline dispensing devices to make old mits look like modem units by cutting down the over-all height some 12 to 18 inches. We were officially concerned about this because under our system of pattern apploval we consider that airy alteration of the original manufacturer's design of a device makes the altered device subject to reexamination or new pattern approval. Moreover, field inspectors become familiar with the appearance of items of equipment and learn to recognize designs that have been approved as to pattern; if a converted unit is shortened by 12 inches, its physical appearance is materially changed and the inspector does not recognize it as essentially the same as the original unit.

When one of these gasoline dispensing units is cut down in height, we will permit it to be used in commercial service provided all of the specification requirements are complied with, but when this work is done by some one other than the manufacturer of the mint, we consider that the manfacturer is relieved of any responsibility for the converted unit.

We found that there was only one firm in New Jersey that was doing this work, and that it had been undertaken at the request of one of the 
oil companies. We made a personal inspection of the facilities and methods employed by this firm, and were entirely satisfied that they could do what they were undertaking in an entirely acceptable manner. We were especially interested to learn whether or not any of the essential mechanical elements of the gasoline dispensing devices were going to be transported or if any questionable hook-ups were going to be introduced. We found out that although the separate elements of the assembly were being mounted closer together than in the original design, no questionable designs were being introduced and everything seemed to be in order.

While we were entirely satisfied with the competence of this firm to do this rebuilding of devices, the question naturally arises about the competence of other's who may enter this field. We shall hold the converter responsible. We are requiring that if any essential part of an assembly is replaced, it must be replaced with an identical element made by the original manufacturer. It has been decided that we will allow the original statement of identification of the design to remain, but that this must always be supplemented by an additional statement to the effect that the unit has been converted, and the name and location of the converter must appear so as to fix responsibility.

In this general connection I may say that during the war, under WPB recommendations, we were limited in the enforcement of our requirements in an effort to keep equipment in service. When the war ended we expected that there would be a general replacement program with respect to gasoline-dispensing devices, because we felt that much of the equipment in service had outlived its usefulness. However, we saw no sign of any appreciable replacement program being started. A recent survey indicated that out of about 30,000 pumps in the State, about 3,000 were in poor condition, with faults such as broken interlocks; illegible numeral wheels; uneffective antidrain valves; and the like. We found that when such equipment was received by this converting firm, they were tearing the units down and actually rebuilding them.

We were somewhat surprised when this conversion movement set in. I do not know whether it will die out or whether it will expand. Anyway, we have it to contend with now, and I have told you how we have handled it in New Jersey. If the equipment is made to operate correctly we are satisfied. Replacement is not our problem, but we are going to see to it that equipment is properly maintained.

The Champman. Is there any further discussion on this subject? Does anyone wish to bring up any other subject for discussion at this time? I might mention that the day I left Minneapolis there was a write-up in the newspapers about an electric taxicab meter. Does anyone here know anything about such a device?

(At this point, at 4:30 p. m., the Conference adjourned, to reconvene at 10 a. m. Wednesday, May 25.) 


\section{THIRD SESSION-MORNING OF WEDNESDAY, MAY 25,1949}

(The Conference reassembled at 10:10 a. m., Dr. E. U. Condon, President of the Conference, presiding.)

\section{TESTING PROCEDURES FOR FOUR-SECTION VEHICLE SCALES}

\section{Bx H. H. Russelu, Chief, Section on Scales, National Bureau of Standards}

The testing of a weighing scale by a weights and measures officer is undertaken chiefly for the purpose of determining whether or not the device is sufficiently accurate, sensitive, and reliable to meet the requirements of the service for which it is intended. Consequently, when planning any test procedure for a certain type of scale, consideration should be given to the general nature of the service and the manner in which, under ordinary service conditions, the scale will be loaded.

This is particularly true of all vehicle scales, the design of which presupposes a relatively long platform upon which will be weighed vehicles or vehicle combinations having various wheelbases ranging from, perhaps, 8 or 9 feet up to the actual length of the scale. Depending on the number and disposition of axles in relation to the total load, various load distributions upon the scale will result.

In recent years, increasing demands for vehicle scales of sufficient length to accommodate the longest vehicle or vehicle combination permissible under existing legal limitations, together with certain economic and engineering problems peculiar to relatively long scales, have resulted in the installation of a considerable number of vehicle scales of the four-section type.

With the installation of an increasing number of four-section vehicle scales, the weights and measures officials have been confronted with the problem of how to conduct on scales of this type tests which will be satisfactory and not attended with unnecessarily extensive or complicated handling of weights. Obviously, it is not sufficient to make only end-and distributed-load tests on these scales which, essentially, may be considered as comprising four separate scales, each susceptible of separate adjustment, connected to a common weighbeam or other weight-indicating element. In actual service there may be times when a major portion of the load to be weighed will be supported by either or both of the intermediate sections. It is, therefore, necessary to plan the test procedure for four-section scales so that the test results will include information concerning the performance of each of the four sections.

At this point it is well to emphasize that the procedures described in National Bureau of Standards Handbook H37 for testing vehicle scales are entirely suitable for testing scales of the two-section type. 
Moreover, the methods set forth in that Handbook for determining elrols, sensitiveness, and constancy of performance are satisfactory in all respects and equally applicable to two- and four-section scales. Consequently, it is not the purpose of this paper to introduce new methods of observation, but to treat in a general way of the manner and order in which the application of test loads should proceed during the known-load-test phase of a test on a four-section vehicle scale in order to develop satisfactory test data through utilization of testing equipment currently available and with the greatest economy of time and effort consistent with the major objectives.

From information gained by testing four-section railway track and motor-truck scales, which are similar in design and subjected to essentially the same kind of service, it is apparent that test loads should be positioned successively over each of the four sections, that the loads should be concentrated is much as practicable mpon the section under test in each instance, and that section loads be applied in at least two nearly eqnal increments, observations being taken at each load interval.

Regardless of the type of testing equipment available for the purpose, the realization of these objectives is easily attained when testing the end sections. It is when tests of the intermediate sections are undertaken that difficulties arise. This is especially true if the testing equipment is of that type which comprises a vehicle equipped with a hoist, a known test load consisting of numerous 1,000-pound weights, and a manually-operated dolly or cart for moving the weights, one at a time, about the scale platform.

Because equipments of the type just described greatly outnumber all others, it is proposed to set forth in some detail three methods for handling the weights during a test of a four-section scale with equipment of this type.

In order to avoid repetitions during the descriptions of these methods, it will be assumed that the weight indication of the scale will be observed following each modification of either the weight value or the arrangement of the test load, and that preliminary tests, such as for SR at zero load and the accuracy of spacing of the weight graduations of minor indicating elements at one-half and full capacity, have been completed. Also, it is assumed that only tro load increments will be used, representing, respectively, one half and all of the test weights available for the test, that unless otherwise stated these weights will be placed in a plane on the scale platform, ano that during each sectional test the weights will be so positioned that the main levers of the section will be equally loaded. Each method will be described as beginning at the left end of the scale with a test of the No. 1 section, although it is recognized that frequently in actual field operations it may be more convenient to reverse the order in which the several sections are tested.

In the First Method, the weights are moved between sections with the dolly; if the testing equipment is of the boom type, and especially if it happens to be of the swinging-boom type, placement of the weights upon and their removal from the end sections with the hoist may be found convenient. The step-by-step procedure should be as follows:

1. Apply one-half of test load at No. 1 section.

2. Double the load at No. 1 section.

3. Move one-half the load to No. 2 section.

4. Remore weights at No. 1 section from the scale. 
5. Weights removed from No. 1 section should now be placed at No. 2 section, thus doubling the load at that section.

6. Move one-lialf of test load to No. 3 section.

7. Remove weights at No. 2 section from the scale.

8 . Weights removed from No. 2 section should now be placed at No. 3 section, thus doubling the load at that section.

9 . Miove one-half the load to No. 4 section.

10. Move weights remaining at No. 3 to No. 4 section, thus doubling the load at No. 4.

11. Remove from the scale one-half the weights.

12. Remove weights remaining at No. 4 section from the scale.

It should be noted that the order of handling the weights during the method just described provides for three observations to be made under distributed-load conditions in addition to two observations at each of the sections under concentrated-load conditions, and that the opportunities for these additional observations are presented as a natural consequence of the order in which the weights must be moved to obtain two-step tests at each section.

The Second Method involves the least amount of manual effort since all placement and removal of weights is accomplished by means of the hoist and the weight-carrying vehicle. It requires that the test weights be stacked in courses if the hoist is of the fixed-boom type and, also, requires much driving skill and ample space for maneuvering the truck into position at various stages of the procedure. The stepby-step procedure should follow the outline described below:

1. Apply one-half of the test load at No. 1 section.

2. Double the load at No. 1 section.

3. Reload weights onto truck which at this point is not on the scale platform.

4. Back truck onto scale, deposit one-half of the test load over No. 2 section, and remove truck.

5. Back truck onto scale, double the test load at No. 2 section, and remove truck.

6. Back truck onto scale, reload all weights, and remore truck.

7. Reverse direction of truck, back onto scale from the right end and deposit one-half of test load over No. 3 section, and remove the truck.

8. Back truck onto scale, double the test load at No. 3 section, and remove truck.

9. Back truck onto scale, reload all weights, and remove truck.

10. Apply one-half of the test load at No. 4 section.

11. Double the load at No. 4 scction.

12. Reload all weights onto truck.

It will be noted that this method does not provide for a distributed known-load test being made during the procedure outlined. There are two primary reasons for this seeming omission; the truck would have to be driven several times from the left to the right end of the scale and back, its position being reversed each time, and fewer opportunities would be presented for observing the condition of the zero-load balance. The last mentioned is of importance considering the many opportunities for balance changes to occur as a direct result of moving the truck to and from the scale platform and operation of the hoist while the truck is on the platform.

The Third Method is of the nature of a compromise in that, while providing definitely for two-step tests at the end sections and for the distributed-load tests provided for by the First Method, the ratio of the two intermediate sections will be clearly indicated at only one load. However, although the movement of weights from section to section is accomplished with the dolly or cart, all shifting proceeds in one direction from either left to right or from right to left, depending on the starting point of the test. Motion and time experiments conducted 
with the Bureau equipment, which is of the swinging-boom type, indicate that this method is very much faster than the First Method and at least as rapid as the Second Method.

In the Third Method, the step-by-step procedure is as follows:

1. Apply one-half of the test load at No. 1 section.

2. Double the load at No. 1 section.

3. Move one-half the load to No. 2 section.

4. Advance remaining weights from No. 1 to No. 2 section, thus doubling the load at No. 2.

5. Mure one-half the weights from No. 2 to No. 3 section.

6. Adrance remaining weights from No. 2 to No. 3 section, thus doubling the load at No. 3.

7. Move one-half the weights to No. 4 section.

8. Advance weights remaining at No. 3 to No. 4 section, thus doubling the load at No. 4 section.

9. Remove one-half the load from the scale.

10. Remove remainder of weights from scale.

Each of the three methods has certain advantages. For instance, the Second Method requires the least manual labor, the Third Method requires less mannal labor than the First, and the First Method is the most complete.

As pointed out in the opening paragraph, the primary purpose of any test is to develop adequate valid data to disclose whether the device under test is suitably accurate and reliable. That being the case, it is improper to judge the merits of a test procedure solely on the basis of operator comfort. Considerable labor is, in most cases, one of the undesirable but inherent adjuncts of the job of testing largecapacity scales. By the use of very specialized, power-driven. mobile test units, such as are in use in Texas, the physical exertion incident to the testing procedure can be materially lessened. In the final analysis, however, the merits of any test procedure should be evaluated in terms of the adequacy of the results obtained.

It seems entirely obvious that the First Method described, being most thorough, is to be recommended as first choice. The Second Method develops leasonably sufficient data, but the validity of the data may be impaired by the relatively large balance changes which all too. frequently occur during the maneuvering of the truck and hoist upon the scale platform. The Third (or compromise) Method, while not yielding quite as much information as the First, does result in considerable valid data and is, therefore, suggested as meeting the minimum test requirements.

Mr. BAUcom. You mentioned the test load, but you did not give the recommended value of the test load.

Mr. Russerc. The paper was just a description of test methods; it was not the purpose to discuss the size of the test load. Whatever the value of the test load available, I suggest that half of it be used for the "half load," and that all of it be used for the second loading.

\section{TESTING PROCEDURES FOR LIVESTOCK SCALES}

\section{By C. L. Richand, Supervisor of Scales and Weighing, Livestock Branch, U.S. Department of Agriculture}

A Federal statute known as the Packers and Stockyards Act of 1921 authorizes the Secretary of Agriculture to regulate and supervise the- 
marketing of livestock at posted public stockyards and at packer establishments where livestock is purchased in commerce. Administration of the Act and enforcement of its regulatory provisions have been delegated to the Department of Agriculture's Livestock Branch. Since the facilities and practices employed for weighing livestock at these supervised market outlets are directly involved in the sale and purchase transactions of marketing, regulatory functions inevitably extend to scales and weighing procedure. This, so far as I know, is the only example of a Federal agency exercising jurisdiction over the commercial weighing of a commodity within the several States.

Under the Act, the Livestock Branch has issued a number of official regulations which govern weighers, weighing, and scales. With respect to the testing of livestock scales, since that is the subject I am to discuss, it should be understood that the Branch does not maintain testing equipment nor does it provide testing service. Instead, our regulations simply place upon the owner or user of a livestock scale at a supervised market the responsibility for having his scales tested, at specified intervals, by a competent agency, in a manner conforming to official instructions and with the test results reported in detail on an official form which we provide. I shall discuss these requirements presently, but first it appears appropriate to enumerate the reasons why livestock scales at public markets are in a special category and merit special test procedure.

1. Livestock has a higher money value per pound than any other commodity commonly weighed for sale or purchase on scales of large capacity. Values of from 20 cents to 30 cents a pound are not unusual. On a busy market at one public stockyard in the Midwest, half a million dollars may be paid for the cattle weighed on a single scale.

2. Other materials and products weighed on large capacity scales form inert and static loads but livestock on a scale platform is generally in a state of motion, imparting dynamic impulses to the weighing mechanism. There is no fixed pattern of load distribution on a livestock scale platform since the animals being weighed may occupy any of several concentrated load positions and, moreover, change position during the weighing process.

3. Practical considerations often necessitate the use of a given livestock scale for weighing an extremely broad range of loads and, whether it be a single calf wejghing 120 pounds or a lot of steers weighing 12,000 pounds, the livestock scale must indicate the weight of both drafts with equal precision and proportionate accuracy.

4. The livestock scale, more than any other, must be positive, precise, and continuously accurate in its functioning, because customary methods of reweighing or check-weighing are not applicable to live animals which may develop material weight losses or gains in a very short time through factors of shrinkage or filling.

The special considerations I have just cited formed the basis on which were conceived and adopted the official regulations governing tests of scales under Branch supervision. As previously stated, these regulations impose upon the owner or user of a livestock scale at a supervised market certain definite requirements. The first requirement is that he shall have the scale tested at suitable intervals and by a competent agency. A suitable interval between tests, in the judgment of the Branch, is not more than 6 months and that is the minimum frequency which was established. In special cases where the performance, condition, or history of the scale. so warrants, tests at lesser intervals may be required. It should interest you to know that some major stockyards, being specially conscious of the need for fre- 
quent verification of scale accuracy, voluntarily arrange for tests of their scales at intervals of $30 \mathrm{or} 60$ days. A competent testing agency is one which can and does conduct tests according to the routine procedure which is describer in the official instructions which I shall discuss presently. Igencies which the Branch qualifies as competent, on that basis, include some State weights and measures departments, a few railioad scale departments, many commercial scale repair and service companies, and several terminal stockyards companies which maintain adequate testing equipment and employ a scale mechanic to conduct tests in the presence of onr official representative.

The second obligation placed upon the owner or user of a livestock scale at a supervised market is that the scale shall be tested property in accordance with official instructions. A proper test, in the opinion of the Branch and in the opinion of any well-informed weights and measures official, is one which fully discloses the performance qualities of the scale under all conditions which may prevail during actual use. It necessarily involves the application of standard test-weight loads in successive stages up to the maximum capacity at which the scale is used; it includes separate tests of individual components such as fractional bars, poises, notches, and main levers or sections which may independently influence weighing accuracy; it demands a reasonably exact mathematical evaluation of the errors which develop under various stages or conditions of platform loading. The official instructions issued for the information of livestock scale owners and testing agencies prescribe a routine procedure designed to establish positively whether a scale does, in fact, meet adopted standards of performance. These instructions are regularly observed at all the public stockyards operating under Branch supervision. For your information and because you should adopt the official test procedures for your own tests of the livestock scales in your local jurisdictions, instructions for testing a livestock scale of the full capacity weigh beam type are included herein, as follows:

\section{Official Test Procedure}

(1) The scale platform should be cleaned of debris and foreign matter which might adhere to the test weights or otherwise be removed during test and cause a change in zero load balance. No other changes or cleaning should be performed since it is important that the scale be tested "as found" if the results are to truly indicate characteristic weighing performance.

(2) Next, with the stock-rack gates secured in "clear" positions and with all poises at zero, the scale should be acculately balanced with 20 or 25 pounds of small-denomination weights on the platform. These "balance" weights will be utilized to accurately measure errors and balance changes during the test. The balance ball is not to be moved during the test.

(3) The SR (Sensibilit. Peciprocal) value at zero load should now be determined by increasing or reducing the amount of balance weights on the platforin until appropriate change in the rest point of the beam or balance indicator is obtained.

(4) The subfractional bar of the weighbeam is now to be tested by setting it successively at 50 pounds and at its capacity position (usually 95 pounds) with equivalent test loads at the center of the platforin and with changes in the balance weights as are necessary to obtain correct balance. The fractional bar is then restored to its zero position and the intermediate fractional bar, usually graduated to 1,000-pounds capacity by 100-pound intervals, is next tested by similar procedure at each notch.

(5) When the fractional-bar tests have been completed and the results recorded, the test weights should be removed from the platform and, with all poises set at 
zero, the scale is to be carefully balanced-not with the balance ball-but by means of the balance weights on the platform. Any change from the original amount of balance weights will represent a zero-balance change and the new amount will be the basis on which errors at succeeding stages of the test are computed.

(6) The test should now continue with the main poise set successively at each 1,000-pound notch and with test loads of corresponding value applied to the platform in reasonably uniform distribution pattern. At each notch and load the amount of balance weights should be increased or reduced as required to produce correct balance of the weighbean or indicator and any difference between the values for zero load and for the load at a given notch shall represent the errol value. These tests slould proceed up to the maximum load at which the scale is used. The SR value at the latter load should be determined, as previously described.

(7) The test weights are now to be removed from the platform and the zelo balance again checked by means of the small balance weights.

(8) Individual corners of the scale should now be tested by applying to each, in turn, test weights equal approximately to one-fourth the value of the largest distributed load, the procedure being otherwise as previously described. In the case of multiple-section scales, a separate test should be made of eacl section with test loads concentrated on each, in turn.

(9) When the corner or sectional tests hare been completed, the test weights should be removed and the zero balance checked to observe the amount of any change. As a supplementary test of the weight-printing device, scale tickets should be printed with the main and fractional poises set at various representative positions. Any difference between poise indication and printing record should be noted.

The third and final obligation of the livestock scale owner or user relative to testing is the requirement that the test results be recorded on forms designed and provided by the Livestock Branch. An exception is made in the case of a State or municipal agency which utilizes a report form containing substantially the same information as is required on the official form of the Branch. Essential information includes identification of the scale and the testing agency, notation of the test dates, and a statement of the maximum and minimum loads normally weighed. It further includes a complete detailed record showing the value and position of each test load applied, the corresponding weight indications, the actual amount of balance or correction weights on the platform at each stage of the test and the computed values of error's, balance changes, and SR determinations. It has been the experience of the Branch that such a record of information and test results is necessary if there is to be adequate supervision over scales and appropriate enforcement of regulations. To illustrate the execution of the official form, there is included (see fig. 6) a sample record of a livestock-scale test conducted at a public stockyard in compliance with official instructions. In this particular instance, to conserve time, only the odd-numbered hundred- and thousand-pound notches were tested; on the next succeeding test the even-numbered notches would be similarly tested.

The following explanatory comments regarding entry of data on the attached sample form will illustrate how the significant information is recorded during the test of a livestock seale:

Entries at the top of the form identify the scale, the conditions of use, the testing agency, and the dates of the present and last preceding tests. Important items of information are those stating the values of the maximum and minimum loads weighed on the scale, for they indicate to the inspector the range of test loads which sliould be employed.

Observation No. 1 records that the scale is accurately balanced with all poises at zero and with 20 pounds of small weights on the platform. 


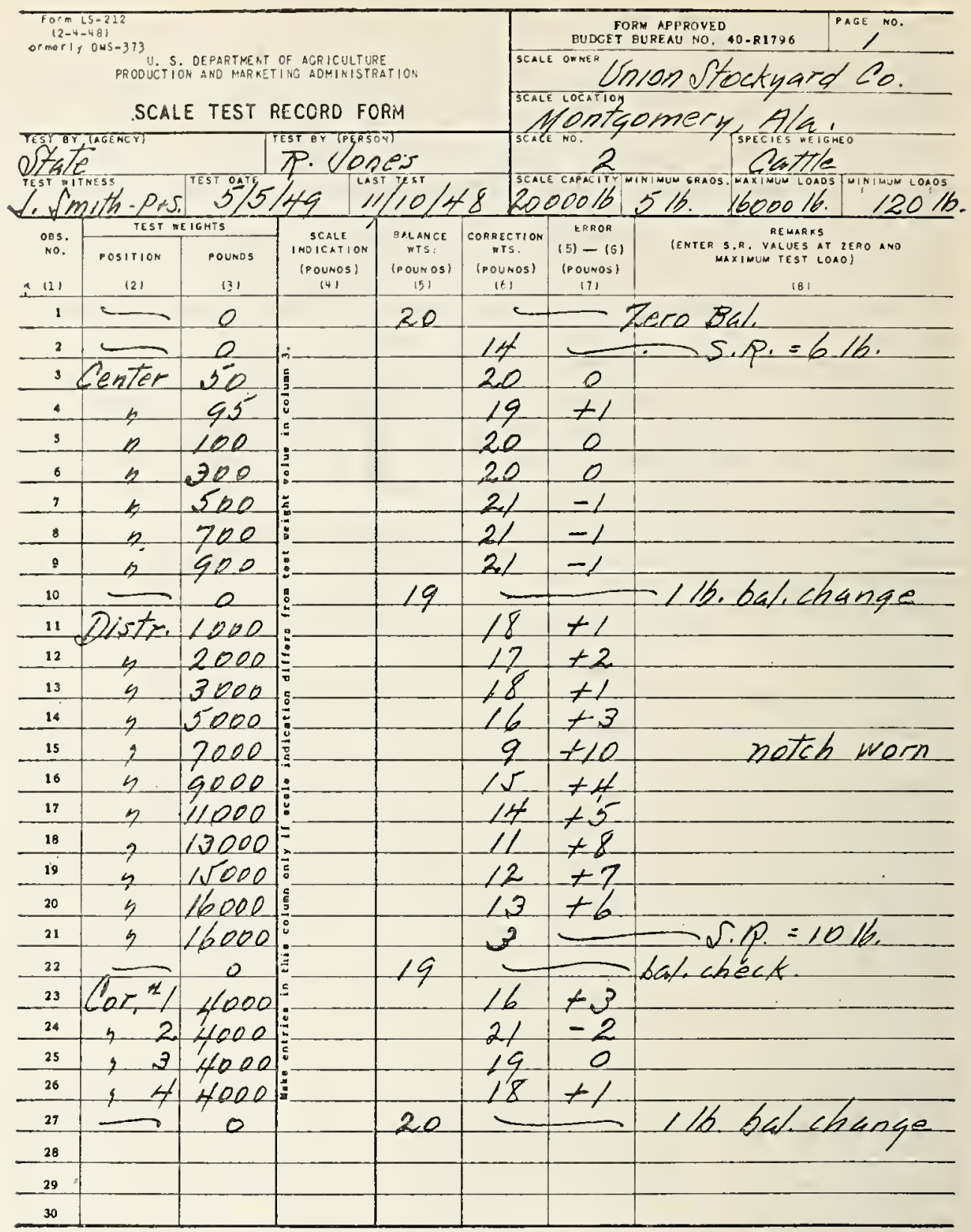

Figure 6. Sample report.

At observation No. 2, the inspector records that the SR value was established by reducing the balance weights from 20 pounds to 14 pounds, a difference of 6 pounds.

At observation No. 3, with a 50-pound weight at the center of the platform (and the fractional poise at a corresponding indication), the amount of weight required to obtain balance does not differ from the original 20 pounds and the error is therefore zero.

At observation No. 4, the difference in balance weights (20-19) represents an error of plus 1 pound.

Observation No. 7 records an error of 20 pounds minus 21 pounds or minus 1 pound.

At observation No. 10, with the test weights removed and the poises at zero, it is recorded that 19 pounds of balance weights is required instead of the original 20 pounds, the difference representing a change of 1 pound in the zero balance. 
Observation No. 15 illustrates a fairly typical example of wear in an individuaI notch contributing an abnormal error.

Subsequent observations register the computed errors for additional distributed loads and appropriate corner loads, as well as the SR value at capacity load and any zero balance changes.

The substance of the preceding discussion may be summarized in the assertion that, in the judgment of the Department of Agriculture's Livestock Branch, based on official experience in the regulatory control of commercial livestock weighing, nothing less than the official test procedure described can be consistently relied upon for adequately evaluating the actual performance qualities of a livestock scale. Nor, in the opinion of the Branch, is a test report sufficiently informative and useful to the scale orner, to the interested market clients, to the supervising agency, or to the weights and measures official unless it records factually, in complete detail, the mathematical values of sensitiveness and accuracy characteristics for representative loads and load concentrations. For these reasons and because of a conviction that the commercial importance and special service circumstances of livestock scales merit your particular attention, I earnestly recomment to the members of this Conference that they adopt, as standard procedure for livestock scales in their local jurisdictions, the testing method and reporting forms which have been described.

Printed copies of this discussion have been provided and are available to you here at the close of this session. If additional copies are desired for the guidance of your inspector's, you may obtain them by addressing a request to the Livestock Branch, P. M. A., U. S. Department of Agriculture, Washington 25, D. C.

At present the U. S. Department of Agriculture has jurisdiction over only some 700 scales at public terminal markets and some 1,500 scales at packer establishments. There are many more livestock scales which are not under our jurisdiction and which must be tested by local agencies. In your community many sale transactions are based upon the weights taken at these numerous auction and livestock markets which are not under our supervision. Some 60 percent of the cash income to the farmers and ranchers of the country is derived from livestock sales. I feel that the scales involved merit, perhaps, more attention than you have been able to give to them.

Mr. Grenne. How many men are used in conducting this test and how long does it take to make the test outlined?

Mr. Richard. The test represented by the sample report form can be made by two competent men in 1 hour.

Mr. Reese. A verage loads in our packing plants and buying stations will run from twenty to thirty thousand pounds. Our trouble is getting enough weights for an adequate test. We cannot carry them, and we cannot compel the owner or the operator of a livestock scale to purchase them.

Mr. Richard. That is a very common situation, and in many public markets we have provided a solution by requiring the scale owner to proride such additional test weights as are needed to supplement the testing equipment of the State. In the case of our markets, we will see to it that necessary weights are provided.

Mr. Rerse. We have used a card, to be posted at the scale, saying that a test load of so many pounds was used in checking the scale. 
At a packing plant recently the superintendent said to me, "We are weighing drafts of twenty-five and thirty-thousand pounds, and you show that our scale has been tested with 10,000 pounds. Do you object if we buy additional weights?" Naturally my answer was "No."

Mr. Ricmard. We have sometimes told the owner of a livestock scale that if he did not provide sufficient test weights to permit a test of his scale to its capacity, we would lock the weighbeam at the amount of test weights available. That is one method which a State might use.

Mr. Baucom. Does your experience indicate that drafts are large enough to warrant the installation of four-section scales?

Mr. Ricmard. 'There are extremely few occasions today where a foursection scale is required in the livestock industry. There has been a transition from the days of rail traffic when all cattle were receivd in carload lots. Ninety percent of livestock received at public markets now arrives in motortrucks and ranges from a single calf to a few head of steers. By and large, 98 percent of the drafts weighed on livestock scales are in less than 26,000-pound lots, and that certainly does not require a four-section scale.

\section{MUTUAL PUBLIC RELATIONS PROBLEMS OF WEIGHTS AND MEASURES OFFICIALS AND AMERICAN AGRICULTURE}

\section{Br Dr. E. V. Moone, Assistant Gommissioner, Department of Agriculture and Markets, State of New York}

Weights and measures officials and agricultural officials have some public-relations problems in common since both are minority groups. In many States the Burean of Weights and Measures is associated with the Department of Agriculture, as it is in my State-New York. Any minority group has to be concerned about its public relations as it is very important to such a group to have the public think well of them. Public relations is the bringing about of a better public understanding which breeds greater public confidence in any individual or any organization. Whether you are a melchant, a banker, a doctor, a lawyer, or a sealer of weights and measures, sooner or later the public will find out what kind of an individual you are. Many people confuse publicity with public relations. Publicity is a valuable tool of public relations, but must not be construed to be public relations. Publicity is what we say we are; public relations is making the public understand what we really are. If we are to be successful, they must be the same.

In your field of weights and measures and in agriculture there is another common problem. The press seldom points out the valuable service that weights and measures officers are constantly rendering to the public. The press usually plays up the violations that are found but seldom mentions the every-day service rendered in protecting the public in seeing that they receive honest weight and honest measure. To build up good public relations in the field of weights and measures, or agriculture, it is necessary to do an excellent job and to be sure that the public-the man on the street-appreciates what the service we are rendering means to him.

Many people in our large cities are at least two generations removed from the land and they know nothing about farmers' problems. They can trace the source of of their food only as far as the family grocery 
store around the corner. Farmers used to be a majority group. When farmers were in such a vast majority they did not have to be concerned about public relations. Now farmers are a minority group-one family on the land supports four and a half families not living on the land. Many of our industries started their public-relations programs around 1930 and liave made great progress in this field. Public relations consists primarily of doing an excellent job and making sure that the public realizes and appreciates the job you are doing. Some of the best public-relations men in this country think that public relations is, primarily, getting the people to understand the good job that is being done.

We in agriculture are trying to establish the interdependence between weights and measures and farmers. It is of little value to a farmer to increase lis production if he is short-weighted when he sells his products. An example of this occurred a few years ago in our State. At that time one of the counties had no county sealer. The sealer had died, and the board of supervisors, which was comprised mostly of farmers, was reluctant to fill the position because they were not convinced of the value of the services of a sealer. Due to several requests for inspection of scales and other apparatus received from coal dealer's and other merchants of this county, the State Bureau assigned two of its inspectors to make a complete check-up in the county. During the course of their inspection they conducted a test on a truck scale located at a railroad station on which the farmers of the area were weighing cabbage prior to its being loaded in railroad cars. The scale was apparently in good condition. It had a new plank platfor'm and was in balance. However, as soon as the test was started it was discovered that, due to several days' rain, the new platform had expanded and had become wedged against the sides of the scale pit to the extent that the scale was iniviaily insensitive to approxiniately five hundred pounds. As a result of this, mnless the tare weights of the trucks were taken at the time the cabbage was weighed, the farmer was losing five hundred pounds on every load that went over this scale. The scale was immediately condemned until repaired. This one incident alone was sufficient to convince the board of supervisors that the service of a weights and measures officer is valuable and that the loss sustained by the farmers in this one instance doubtless was snfficient to pay the salary of a sealer for an entire year. 'This shows what can happen when a community does not understand and appreciate the economic value to them of weights and measmes service. I great part of the farmer's purchases as well as his sales are directly dependent on weights and measures. Officials of agriculture, like officials of weights and measures, have a constant problem in seeing that their inspectors and sealers are good public relations men as well as efficient agents in protecting the public. Perhaps it would be well for us to take a few minutes to review the agricnltural situation so that we will be on common ground in our comparisons.

American agriculture is the marvel of the world in size, in speed, in complexity, and in success. It has mastered the machine: it has harnessed research; it has developed great leaders; and it offers opportunity equal to any business or profession. The gross income of American agriculture last year was more than thirty billion dollars. 
These are times when we hear "million" and "billion" used almost interchangeably, but there is a great difference between a million and a. billion. For instance, we all know what a second is; there are $60 \mathrm{in}$ a. minute, 3,600 in an hour. A million seconds is 11 days and 8 hoursa short vacation-while a billion seconds is 32 years and 8 monthshalf a lifetime.

American agriculture employs more people than any other industry. American agriculture uses more petroleum products than any other industry. American agriculture has doubled its production per man in the last decade. It produces five times as much per man as it did in Civil War times. There are four reasons for this marvelous production record: (1) More than two-thirds of the farms in this country are operated by the owner and his immediate family, which furnishes an incentive to get ahead; (2) the agricultural-implement people, through engineering and research, have developed some great laborsaving devices; (3) agricultural research has been one of the prime features in helping to establish this marvelous production record, in that it has developed the know-how-for example, it has created new varieties of grains that are more disease resistant, have greater growth and greater yield; (4) the important part played by agricultural organizations in this production record.

All the agricultural organizations have helped but the one organization that has had the greatest bearing on this production record is the extension service. A piece of agricultural research has little bearing on production as long as it is filed away in some institution. When the county agricultural agents evaluate this research and reduce it in a practical way at farm level, it is close to being applied. When the farm owner and his associates discuss the practical application of agricultural research around the supper table, that research is getting close to helping to increase production.

Several youth organizations have been very helpful in this production record-for instance, the 4-H Clubs of America. They have done a marvelous job in interesting the youngsters in better agriculture. As of October 1, 1948, there were 80,286 organized 4-H Clubs in the United States with a paid membership of 1,759,911 active members. The 4-H Clubs have trained more than 14,000,000 boys and girls. 4-H Club boys and girls are getting proper training to lead the largest business in America, as well as training that will be helpful to them should they take up any other occupation. We hope many of them will stay in agriculture, but we realize that many will find their way into industry. It is a great satisfaction to me to see that some of the junior captains of industry are 4-H trained boys.

These 4-H-trained boys who enter other fields are agriculture's greatest potential public relations men because they understand agricultural problems and will be able to build up centers of good will toward agriculture. From a public-relations standpoint alone, the 4-H Clubs are well worth while. It will be only a few years until these boys and girls who are now in 4-H work will be replacing us in agricultural and industrial America. We should never miss an opportunity to make sure that these boys and girls understand agriculture's public relations problems. One of our most difficult jobs is to make the average American housewife realize the contribution that agriculture has made to a better American diet. The 4- $\mathrm{H}$ girls of 
today will be the housewives of tomorrow, and I am sure they will understand agriculture's public relations problem.

You in the field of weights and measures have a wonderful opportunity to gain a better appreciation of your work by talking to 4-H groups and explaining the service you are rendering to the public. Such talks would be of great interest and mutual help. These boys and girls in turn will be potential public-relations people in the field of weights and measures as well as agriculture. 'The 4-H members could easily be shown the advantages to them of the work you are doing. 'They ar'e always interested in new ideas, particularly if they are related in some way to agriculture. For instance, one of the least understood but very important functions of present-day weights and measures departments is to assist industry in maintaining its standards of weights and measures. Protection of the consumer against fraud is still our foremost duty and consideration. Nevertheless, there can be no mass production as we know it in this country-of machines such as automobiles, farm machinery, and the like, or of merchandise sold by weight or measure-without the means of insuring the constant accuracy of our industrial standards. The standardization of parts in farm implements is a great benefit to the farmer. Today a broken part of a mowing machine or a tractor usually means only a call on the nearest dealer handling that machine in order to secure a duplicate part to replace the broken one. If these parts were made by hand as in earlier days, the machine would be satsifactory when new; but when it became necessary to replace worn or broken parts the replacement parts would also have to be made by hand by the original manufacturer or by a local mechanic or a machine shop. No longer than 20 years ago, a broken machine part usually meant days of lost time.

While New York is known as an industrial State, it plays an important part in the nation's agriculture. New York State's agricultural income last year was more than 900 million dollars. The livestock industry - the major part of which is dairying-furnished 70 percent of this income. New York State's milking herd-that is, the milking cows exclusive of dry stock and young stock-averaged 1,400,000 cows. If these cows were stanchioned in a barn with a row on each side as we are accustomed to see them, with the platform between them wide enough for a railroad track, it would take a fast express train more than! hours to run through the New York State milking barn.

New York State farmers are fortunate in having enormous markets. More than 25 percent of the population of the United States lives within a 250-mile radius of New York City. Living in an area of consumption is a distinct advantage to the producers of food. It is regrettable, however, that so many of the people in the densely populated areas of the nation do not realize where their food comes from. These same people who do not know where their food comes from also do not appreciate or understand the great protection you weights and measures people are giving them. No doubt the problems of weights and measures officers are more difficult in the highly populated centers of the country. In agriculture, one of my prime objectives is to try to make the people realize the interdependence between American agriculture and American industry. This might apply as well to your weights and measures situation. It would seem to me that one of the $858144-50-6$ 
biggest problems you have is to make the man-on-the-street realize what your eflicient service means to him. Two major points of your problem are: First, doing a good job; and second, making the people understand what this job of yours means to them. There are many speakers here who have shown you, or will show you, how to do a better job in your work. What I am discussing is the second phase-how to make the people, both urban and rural, understand the economic value of your work to them.

Public relations is everybody's business. A corporation may hire a good public-relations man, but unless he has the support and backing and cooperation of every salesman or contact man in the organization his efforts will be ineffective. A good public-relations man is essential to an organization to create the ideas, and the methods for transmitting them to the public; but if they are not carried ont in both the spirit and the letter by everyone in the organization who meets the public, their effectiveness will be greatly curtailed. It has been said, "It often takes many wise men to repair the work of one fool." In our Department of Agriculture and Markets an inspector who does not understand the public relations side of his job can make it difficult for his bureau and all his associate inspectors.

Both weights and measures and agriculture should expand their public relations programs; they must try to get the general public to appreciate the services we are rendering. According to the best public-relations men, the best way to accomplish this is by press releases, radio, the spoken word, and pamphlets. Most sealers could develop an acquaintance with the local press if they have not already done so and could give the press some interesting short items that show clearly the valuable service they are rendering to all the people of the community. It would be advantageous to have this type of notice rather than stories about fines and prosecutions. Our principal duty and responsibility is to see that the people receive honest weights and honest measures; fines are only a means of handling the group who cannot be convinced that the right way is the best way for them. In the Food Control Bureau of our Department we could fine a restanrant proprietor every week of the year for unsanitary conditions of the premises or dirty food, but the public would still be served dirty food. The big job is to sell the proprietor the idea that carrying out our regulations with respect to cleanliness of the food and of his establishment will attract good business.

Many radio stations would welcome a chance to interview a weights and measures officer about the interesting things he is doing to protect the public. Some sealers are taking adrantage of this. and it is being well received. It is something that should be developed.

Both groups-agriculture and weights and measures-have an opportunity to get their story before a cross-section of the community by talking about their work to service clubs. I have talked to a great many service clubs about agriculture and I know that you have an opportunity to use the same field. In New York State, the Burean of Weights and Measures is associated with our Department of Agriculture and Markets, and on many occasions in talks at service clubs about our department I have told instances of the good work that this bureau is doing. Everybody shows a keen interest in this phase of our department's work. You liave an opportunity to get your causo before 
an influential audience when you talk to these clubs. It is easy to sell a talk to an audience when it means personal economic gain to them. It would seem to me that weights and measures officers would also have an opportunity to discuss their work before many women's organizations. Most women are price conscious but not weights-and-measures conscious. Talks along the line of helping them to help themselves by seeing that they receive just weight and just measure would create some valuable centels of good will.

I want to make it clear that I am not being critical, but with minority groups like agriculture and weights and measures it is customary to tell about our good work at our own meetings rather than to tell responsible people of our communities about it at their meetings where it will do our cause some good. In a way we are both like the minister who was talking to the handful of his congregation that attended services one Sunday and was giving them a good goingover for not going to church. WVe tend to talk to people who are already familiar with our work or associated with it, rather than to the people who do not understand and should be enlightened about the service we are rendering to them.

Many industries have used pamphlets very successfully. I would like to see a small pamphlet with pictures, or line drawings, illustrating some of the principal services that weights and measures officers are rendering, but with very little written description. It has been said that a picture is worth a thousand words. If we are to interest our public we must be brief-use more pictures and less words. One of the best hotel ads that I have ever seen is a billboard picturing a typical American family with children leaving the DeWitt Clinton Hotel in Albany. The only printing on the sign besides the name of the hotel is, "They all speak well of it."

Public relations is coming to be recognized as a powerful force. Its first concern should be the public's interest. If skillfully used it can do much to bring harmony, peace and prosperity not only to business but to the nation.

To accomplish anything of lasting value, our program must be a continuous, long-range, year-to-year operation. Good will can not be written on the books over night and it will not stay on the books without frequent entries. We must make our entries every day; we must do something every day to improve our public relations. The goal toward which we are working is a simple one-a better standard of living, self-respect, and self-confidence. Honest, accurate work and honest, accurate information about our work is the basis of good public relations. Know it; tell it; that is our public-relations job.

Mr. Warner. Dr. Moore has given us a fine illustration of the immensity of the daily business when he sighted the length of time it would take a train to pass all those dairy cows. I might say that if all of the dairy cows in the State of Wisconsin were made into one big cow, that cow's head would be grazing the lush grass of the pampas of South America, that cow's tail would be flicking icicles off the Arctic Circle, and that cow would be milked right in IVisconsin!

\section{ANNOUNCEMENTS BY THE SECRETARY}

Tine SEcretiry. I wish to remind you of the open hearing of the Resolutions Committee scheduled for $5: 30$ this afternoon, at which 
tho Committee will receive your suggestions with respect to resolutions. Similarly, thirty minutes after adjournment of our afternoon session tonorrow, the Committee on Nominations will hold an open hearing to receive your suggestions regarding nominations for office. At nine o'clock tomorrow morning the Chairman of the Committee on Legislation has called an executive session of his Committee.

I would remind you again that Mrs. Carrie Woodland and Mrs. Margaret Meek are representing Mrs. Saybolt of the Scale Journal at this meeting. I have received a wire from Mr. Belle Isle, of Johm Chatillon \& Sons, advising that a surgical operation was responsible for his absence from this meeting and extending his best wishes for a successful Conference.

\section{SHRINKAGE ON PACKAGED WHEAT PRODUCTS}

\section{Bу J. L. Harver, Director of Litigation, Federal Food and Drug Administration}

When I first received an invitation to speak to this Conference I accepted with a great deal of enthusiasm because I welcomed the opportunity to become better acquainted with this group. After I learned from your secretary the topic that had been assigned to me to discuss I wondered whether I had not been too hasty.

In my Division of the Food and Drug Administration we have the duty of evaluating evidence submitted by inspectors and analysts in order to reach a conclusion as to whether or not there has been a substantial violation of the law. If the conclusion is affirmative, it is our responsibility to insure, insofar as we can, that any case filed is carried to a successful termination. The evidence dealt with represents a widely varied pattern and subject matter and deals only incidentally with the question of short weight. It is from a background of considerable experience in evaluating and presenting cases under the wide pattern of the Federal Food, Drug, and Cosmetic Act that I approach my assigned subject rather than as specialist in shrinkage in cereal products.

I recognize that State and local laws dealing with net-weight requirements are not necessarily icientical in all respects with similar sections of the Federal law. This makes it difficult to discuss the development of cases generally since invariably the facts in each particular case must be considered in the light of the applicable statute. In addition to considering the facts and the statute as written it is also necessary to take into account the various precedent decisions of the courts that may be binding or highly persuasive to the trial contr in the contemplated case.

Under the Federal Food, Drug, and Cosmetic Act the question of variation from the declared quantity of contents in all food products is spelled out so that the allowances that must be made are clearly apparent. The variations permitted are two in kind. First, those which occur in good manufacturing practice and which camnot reasonably be avoided. Such variations from the declared net weight must be as often above as below and the average on a representative sample must be as great as the declared net quantity. Unreasonable variations outside of good manufacturing practice are not permitted in 
the individual units. All of these considerations apply to manufacture and packaging and do not directly involve the question of shrinkage. The second variation clause deals with those variations from declared contents that are caused by ordinary exposure to conditions which normally occur in good distribution practice and are unavoidable. Any product which contains moisture or water as an essential ingredient of its identity, unless hermetically sealed, is affected by atmospheric conditions. 'The effect is not necessarily shrinkage or loss in weight and in fact some commodities, under some conditions, gain in weight due to absorption of moisture while they are held for sale. Shrinkage or loss in weight in a packaged wheat product may occur after packaging through leakage or sifting. This arises where containers are inadequate or improper for the article or where the conditions of handling are such that the packages are actually damaged. To briefly dispose of shrinkage that occurs from leakage or spillage it may be said that these are not conditions which normally occur in good distribution practice and which unavoidably result in change of weight. Further, taking flour as an example, if the purchaser or consumer receives a package that contains less flour than the quantity declared on the label that person is directly cheated. Short weights arising out of leakage require no allowances and should be dealt with accordingly.

The situation is quite different when the shrinkage or loss in weight occurs by reason of the evaporation of some of the moisture content. Cerea $\bar{l}$ products are invariably treated to make a batter or dough before being cooked into a food for consumption and the process of preparing for cooking always involves adding moisture to the article. For this reason loss of moisture within those reasonable limits that do not alter or change the quality or identity of the article is compensated for in preparation for the table. This fact constitutes the basis for allowance for unavoidable shrinkage while the product is awaiting sale or use since the same amount of food or the same size loaf of bread would be produced from a given quantity of flour whether its moisture content before mixing with the other ingredients is 12 percent or 14 percent.

There is an important part of the variation clause with respect to shrinkage in the Federal law which I have not as yet emphasized. This relates to shrinkage variations that occur after shipment in interstate commerce. It is to be presumed that normally the manufacturer does not have control over all phases of the shrinkage question after the product leaves his hands. Whether we are dealing with a shortweight case under the Federal law and dating our shrinkage allowance from the time when the product was introduced into interstate commerce or proceeding under State or local laws, it would appear that properly shrinkage allowance should begin to rum at the time that the article leaves the manufacturer's hands and control. Shrinkage which might occur while the goods are still in possession of the manufacturer should not be allowed for in evaluating a net-weight case. It is the duty and the responsibility of the manufacturer to sell his product full weight and he cannot expect credit for variations that occur between time of manufacture and time he sells it to a dealer. 
In properly evaluating shrinkage through loss of moisture the moisture content of the article at the time of sale is of primary importance. The mere fact that there is a maximum legal limit for moisture in flour, e. g., does not mean that shrinkage loss must be calculated downward from 15 percent. Actually flour does not normally rum as high as 15 percent in moisture, and to invariably assume that it does would be to afford an opportunity to manufacturers to take advantage of the public by actually packing short weight.

It has been suggested to me that my remarks would be more helpful to weights and neasures officials if I could give concrete statements which will enable field inspector's to determine on the spot with finality when shortage is and is not due to shrinkage. It has been pointed out that field inspector's frequently do not have laboratory facilities readily available and do not have on hand authoritative information regarding the shrinkage to be expected under the conditions of handling and storage. I would be pleased indeed if I could lay down an iron-clad rule that would serve as a guide for an automatic conclusion in each case regarding the shrinkage question. This is not in my opinion possible. There are so many variable factors involved that no specific tolerances can be established and every case must be considered on its own special facts. The amount of weight that a food product will gain or lose by reason of its exposure to atmospheric conditions depends upon the nature of the food itself, upon the type and size of the container, upon the atmospheric conditions, and upon the length of time that the food is subjected to those conditions. It seems, therefore, that accurate allowance for shrinkage through loss of moisture in any specific instance must be based upon experimental data which are acquired under conditions which parallel most closely those conditions which are found in the lot or shipment under consideration. This is not to say, however, that before action can be had in any case of short-weight packaged wheat foods a special experimental study must be made on the particular lot. 'There are available published and otherwise an amount of accumulated data based upon experimental study which are extremely helpful. In applying such data it is necessary, however, to make certain that the facts and circunstances are sufficiently similar as between the experimental conditions and the conditions of the lot under investigation to justify the application of the experimental data. Most of the work that has been done was done on flour and it is interesting to observe that the results of experimental work obtained by the Government and weights and measures ofticials and the industry are in close accord. Flour is hygroscopic and tends to reach a moisture equilibrium with the surrounding atmosphere. Flour of low moisture such as 10 percent stored for even a short time in a high humidity such as 85 percent will gain weight but flour of higher moisture content such as 14 percent stored at a low humidity such as 30 percent will lose weight. Experinentally it appears that flour of a moisture content of around 13 percent shows little, if any, change in weight under a relative humidity of about 60 percent. Some graphs which clearly illustrate my remarks are shown in figs. 7 and $S$.

Perhaps many of you are familiar with an article by Anker, Geddes, and Bailey in "Cereal Chemistry, Vol. XIX, No. 1, January, 1942." The data contained in that article plot out very closely in line with 


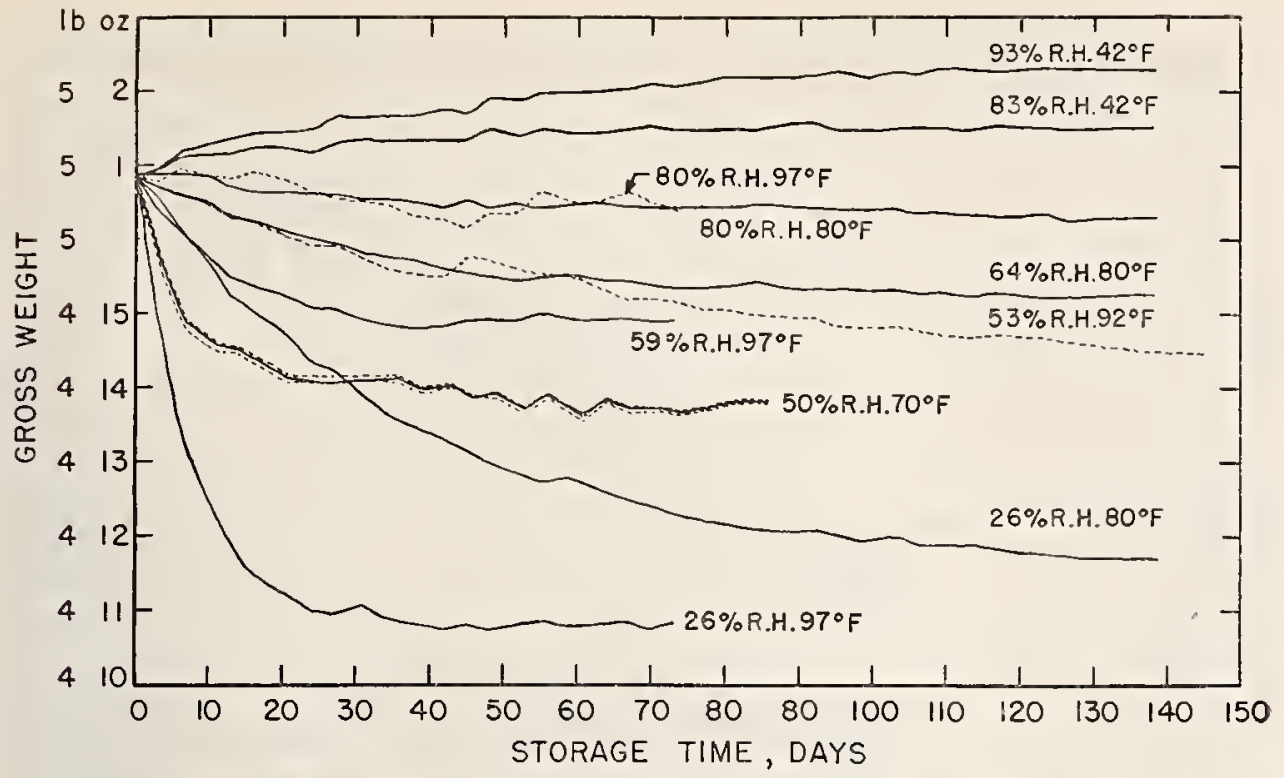

FIGURE 7. Weights of 5-pound sacks of four stored at indicated constant temperatures and humidities.

the work that we have done and which is in part illustrated by the graphs. Some of the significant conclusions are:

1. The rate of change in weight depends on the difference between the original moisture content of the flour and the moisture content to which equilibrium would be obtained and upon the size and kind of package.

2. The rate of moisture loss on exposure to low relative humidity is much more rapid than the rate regained.

3. Hygroscopic equilibrium of flour at constant relative humidity varies with temperature, and the past history of the flour has a distinct bearing on the weight change.

Our own conclusions are similar-relative humidity and temperature of storage are the primary factors which determine change in moisture content in flour. Flour ultimately establishes an equilibrium or final moisture content. At a constant hmidity the final moisture content is higher at low temperature and lower for high temperature. Generally speaking the higher the temperature the more quickly equilibrium is established.

To make an accurate evaluation of the allowance to be made for shrinkage based on calculated data one must have knowledge of the moisture content of flour at the time of sale by the manufacturer. The actual data ou shrinkage experiments on flowr, as acquired by the Food and Drug Administration, and shrinkage data on other products are not generally available for distribution, but any State or city official is welcome to look over the material at any of our field offices.

In considering a case involving short weight where the product contains moisture the question of shrinkage can be wholly excluded only if the packages are air-tight or if the weighing is done at time and place of sale or shipment by the manufacturer. In affording a court and jury adequate opportunity to appraise the facts with regard to shrinkage, information as to the packaging and reighing practices of the firm at time of packing is invaluable. Some of the questions that 

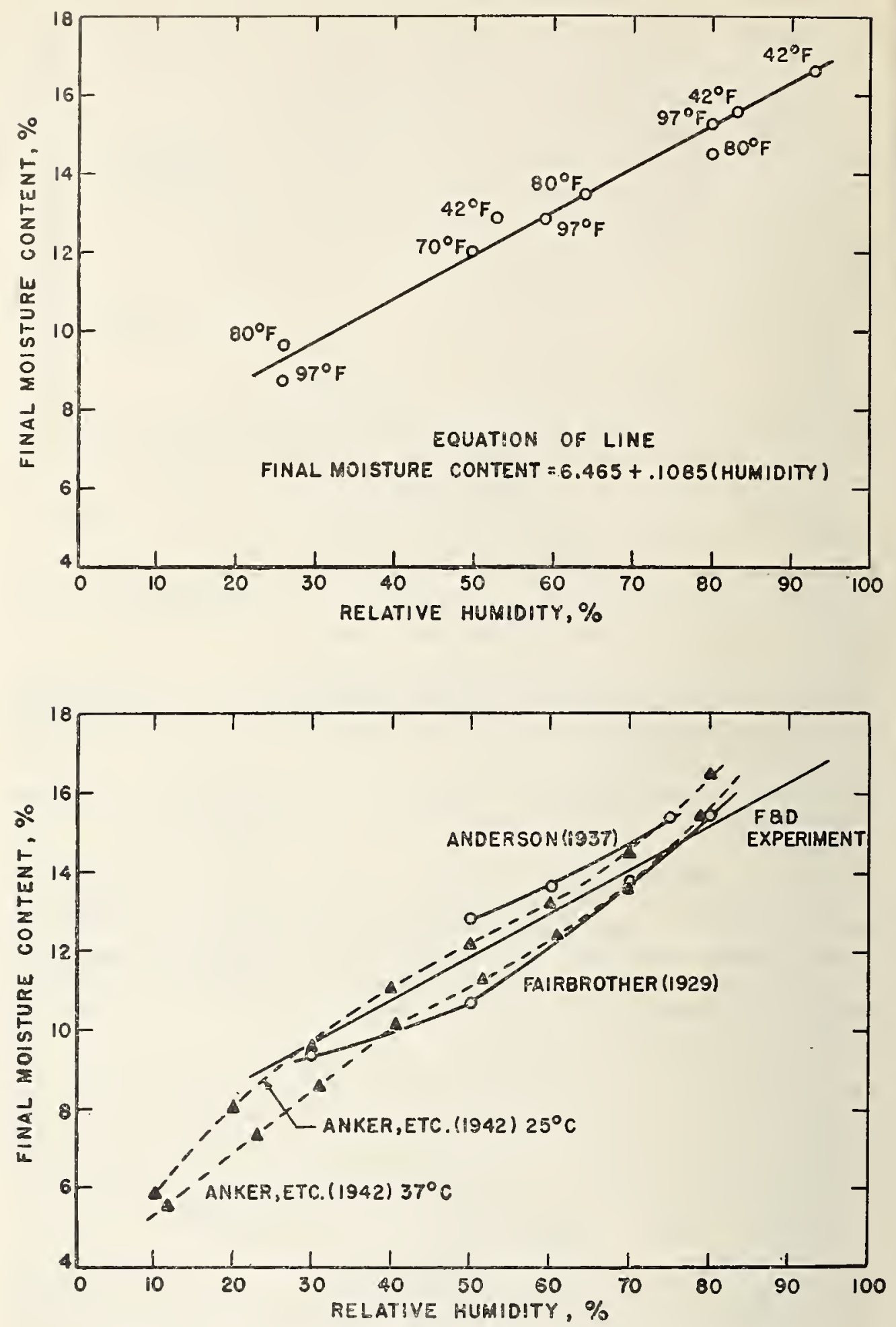

Frgure 8. Relationship belween humidity and final moisture content.

Upper graph: F and D experiment with 5-pound sacks of flour of 15-percent initial moisture content.

Lower graph : F and D experiment compared with results of other investigators. 
should be covered are: Does the manufacturer in packing make an allowance for shrinkage? Does he at time of packing use automatic machinery to insure full weight in each package or does he fill containers without specific regard to weight? Does he independently make adequate check of the actual net weigint to insure that automatic packaging or other form of packaging is accurate?

It is entirely necessary to have accurate information as to the period of time which has elapsed since the article left the manuiacturer's hands and to determine what the temperature and humidity conditions have been during that period. Data as to temperature and humidity are available from the Government Weather Bureau.

In considering the question of shrinkage it must be remembered that the law, if it be the same as the Federal law, allows shrinkage which normally occurs in good distribution practice and which unavoidably results in loss of weight through shrinkage. If the storage conditions are not normal and customary the shrinkage allowance is not the same. For example, the acceleration of moisture loss through storage in over-heated rooms and the exposure of portions of the lot to abnormal conditions such as piling around radiators or heat vents are abnormal conditions in storage and distribution. It is necessary therefore that the inspector make careful observations for the conditions of storage and it is outstandingly important that the units weighed and examined be a truly representative sample of the lot or if there are obvious reasons why there is likely to be a variation in portions of the lot, that the sampling and weighing operation be so designed as to give a true picture. It would seem obvious that in most instances a laboratory determination of the moisture content on a representative sample is imperative before any calculations or allowances with regard to shrinkage can be considered. If the moisture content at the time of the weighing and sampling is normal for the product at the time of manufacture it is unreasonable to undertake to account for shortage in terms of moisture loss. Valuable data can be obtained by rechecking on laboratory samples after the original weighings are made to determine whether there is a progressive change in shrinkage, both as shown by moisture determination and reweighing. Naturally the temperature and humidity conditions applicable to the samples stored in the laboratory must be taken into account.

Summary. There are no complete tables of shrinkage which can be used by an inspector in the field to summarily conchude on the spot the allowance that should be made for moisture loss after sale by the manufacturer of packaged wheat products. The original moisture content of the article is an important factor. The weighing practices of the manufacturer must be considered to determine whether shortage is likely due to shrinkage or to poor manufacturing practices. The case is unworthy of consideration unless the weighings constitute a truly representative appraisal of the lot. There are available published and unpublished data upon experimental shrinkage studies which are extremely valuable but which must be applied only after due consideration of the similarity of facts and circumstances. Since time, temperature, and humidity are the primary controlling factors these must be known and taken into account. In presenting the case in court these data must be available in a form that can be proven.

Lastly, the enforcement officer must be reasonable and must be satisfied that he can effectively meet any contention as to shrinkage that 
may be made by the defense. This reasonableness does not compel him to forego the filing of a case merely because a claim of weight loss throngh shrinkage is likely to be made but it does compel him to reach a sound conclusion on facts that can be proved that the article is significantly short weight, and he must realize that his own expert conclusion must be translated into terms that fully and honestly persuade a jury so that they have no substantial doubt that the article is short in weight and not merely because of partial evaporation of the moisture content after the manufacturer sold it.

I have deliberately not included in this paper the actual data that have been obtained on shrinkage in flour under various conditions, first because it is impracticable to make this article a shrinkage compendium and second because it would be less comprehensible than I hope it is if I undertook to read to you an accumulation of percentage figures, together with acknowledgments to various scientific workers which should properly be made. I can repeat that our shrinkage data are available for cooperating enforcement officials and may be examined at any of our offices. I have not attempted to recite to you the opinions of courts in a significant number of cases since what the judge said in one case is applicable in another only if the facts are the same and, after all, if the facts prove the charges the result is a verdict for the people and the protection afforded under the law has been given in the particular case.

Mr. Suotgh. It is my understanding that wheat is normally purchased on a 10 percent moisture basis, that prior to the milling operation approximately 3 percent of moisture is added, and that this is usually the moisture we are concerned with.

Mr. Harver. That is called "tempering". That may be the moisture we are concerned with but, by law, flour may contain 15 percent of moisture.

\section{STAND-BY SERVICE OF TESTING EQUIPMENTS DURING REPAIRS}

\section{Br J. F. True, State Seater, Weights and Measures Division, State of Kansas}

Our friend Mr. Ralph Smith has asked me to discuss this subject, and with your permission I want to limit this discussion to testing equipment and repairing or adjusting which would be done on largecapacity scales, especially the truck, wagon, and livestock scales which are to be found at elevators, coal yards, lumber yards, livestock sale barns, livestock terminal markets, and on farms or ranches. For this discussion I am thinking of this in a jurisdiction where no charge is made by the Weights and Measures Department for the testing service. Where a charge is made for this service there might be a little different attitude on the part of the scale owner than where the testing is supported entirely by taxes.

It seems to me that this problem divides itself into tro different parts. One part is to get the weighing devices repaired and in use as soon as possible with the least expense for adequate and satisfactory repairs, and the other part has to do with the public relations between the inspector or governing body, the scale owner, and the scale service man and the company he represents. I liave not tried to list these in the order of their importance because I feel they are all important and tie in very closely with each other. 
I might state that in Kansas our general policy is to stay as far away from the scale service men while they are repairing scales as possible, but still be as close to them as possible when they want our cooperation. We want to encourage the good men because we need them. On practice is to recheck a scale as soon after it is repaired as possible, and because of the shortage of service and repair men, and lack of cooperation of the scale owners, we have found it dificult to get all of the scales repaired within a reasonable time after they have been condemmed, so that they can be rechecked in the order they were condemned.

In Kansas we have tried to keep our relationship with the scale owners on the basis of giving them a service rather than have them think that we are out to catch somebody who has tampered with his scale, or is purposely cheating the customer. While we cannot suggest that the owner of a scale employ the service of any certain shop, yet we do have a list of scale service men and scale service companies that are available to take care of their trouble, and a list of these commercial service agencies is left whenever a scale is condemned, so that they cannot say that they do not know where they can get good, reliable scale service.

We believe that the best way to get the whole-hearted cooperation of both the scale owners and the scale service men is to treat them as we would like to be treated if we were in their position. They should understand our position and we should not hesitate, in fact, we should make it a point, to be sure that they understand the weights and measures laws and understand that our department is more than busy doing strictly testing work, and therefore any delay at one scale will deprive someone else of a test that he deserves. However, the Weights and Measures Department and its officials must be ready at all times to give service and advice and connsel on the subject of weighing and measuring to any and all who wish such a service, and as public officials we must take our job seriously and devote our best efforts and full attention to the people whom we serve.

It is hard to make rules that will cover every situation encountered by the inspector who is in the field and must make decisions on the spot. Therefore, we in Kamsas have some over-all policies, but yet we want our inspectors to feel free to use their best judgment when they are out on the job. In most cases it is not desirable, and we think not practical, to have the State equipment at a scale when the service man is doing the repairing or adjusting unless the scale has been condemned a second or third time, and thus is a problem case which may need the best judgment and serious thinking of the inspector, the scale service man, and the scale owner, and the additional weights or other equipment owned by the State. However, this should be only at real problem cases.

The size of the trucks now using the scales of commerce have increased in size, and also the capacity of the scales used to weigh these loads has increased. Now, it is important that the amount of test weights used by the official tester's be increased so that they have sufficient weights to test a scale to near capacity. In Kansas the commercial scale service companies also need to increase the weights carried. We have one company that carries as much as 10,000 pounds, but I am sorry to say the rest of them are far short of weights for testing the 50 -ton scales. 
I an sure most jurisdictions do not have the equipment or personnel to give stand-by service to all commercial agencies, so we had better not try to give it to any except the special cases.

I believe, if I were a service man, I would prefer to go about my work in my own way, and until I had tried my best to put a scale in proper working condition I would prefer to do this without the assistance, and not be under the scrutiny, of a scale inspector. I would prefer to work out most problems by myself or with the scale owner, but would be glad to have the service and equipment of the Weights and Measures Department on special cases.

I presume that in most of your jurisdictions, as it is in Kansas, there are certain service men who are trying to get started in the business on their own, and for the most part these men are good, competent men, and most of them have had training while working for someone else, and these men may need in some cases the use of the equipment which is at the command of the inspector. I know in Kansas that we want to encourage these men, but yet we do not want to give them so much help that we might be criticized by other service mien or agencies.

In Kansas we have adopted a policy of doing no repairing and practically no adjusting on any weighing device, and I believe this is a good and sound policy, even though in some instances it might save a little time and a little mileage; but in most cases we find that in doing our recheck work we pretty much have to cover the same territory the second time and the mileage involved is not very great. If possible we would rather wait a few minutes if the service man can be obtained quickly, or come back before we leave town and recheck the scale while the service man is still there and after he has made his a djustments. We feel that we cannct put ourselves in a position of being both testers and repairmen because we would probably do a poor job of both, and we want to encourage the repaimen rather than discourage them.

'There are some advantages of having the weights and measures inspector at the scale at the time it is being repaired. As I have mentjoned before, it may save time and it may save additional travel. However, it may take more time, because we test from five to eight scales a day, and scveral hours can be lost waiting for a service man to finish the repairs. The inspector also has an opportunity to observe the work of the scale service man and the scale service man may do a better job while the inspector is there. When the scale service man gets the scale so it passes, he is reasonably sure that the scale will not be checked again for at least a year, and possibly longer. To the scale owner it is no doubt quite an advantage, especially in Kansas where there is no charge for the scale testing work. In most cases he is assured that the job will be completed to the satisfaction of the Weights and Measures Division, and there is not much chance of having to have the scale service man makc a return call, which might be the case if the scale were condemned on the retest. The majority of scale owners are not very familiar with the parts of a scale which are under the platform or out of sight; therefore, the owner relies on the judgment of the scale service man and the test of the scale inspector, and I think he feels that the scale inspector is no doubt looking after his interest. Thus the scale inspector has an additional responsibility to see that the equipment is in such condition that it should give good performance for a reasonable length of time.

I suppose in most of your jurisdictions you have the problem of get- 
ing adequate finances, which in turn limits the equipment available, and limits the number of inspector's and perhaps the type of men whom rou are able to employ as inspectors. For this reason it is necessary that the funds available be made to go as far as possible. Because of the limited funds and persomnel it is important that all equipment be used to the best advantage, and I believe that adequate wages should be provided for personnel that is capable of administering weights and measures work in such a way that the work will be supported by the general public, by the service men, and by the manufacturers of weighillg equipment.

The maintaining of proper weighing conditions in commerce is the responsibility of manufacturers, the scale service agencies, the weights and measures oflicials, and the owner of the equipment. This is a fourhor'se team and each horse mist be willing to pull his own load, because if he does not it puts an additional load on his teammates. Our country has made great advances in all lines, so let us show real leadership in the advancement of fast and accurate weighing. By the full cooperation of all, this will be accomplished.

REPORT OF THE NATIONAL CONFERENCE COMMITTEE ON WEIGHTS AND MEASURES EDUCATION, PRESENTED BY J. T. KENNEDY, CHAIRMAN

Your Committee on Education has not been as inactive, since the Thirty-Third Conference, as may have appeared on the surface. Members of the Committee have traveled thousands of miles, attending many conferences, schools, and meetings of various kinds, always with the thought in mind of encouraging weights and measures education and observing progress being made, in the different jurisdictions, along this line.

We are glad to report that all 12 State Weights and Measures Associations and the 2 regional associations have held regular conferences since the 33rd National Conference. These meetings were well attended, and exceptionally constructive programs were presented.

During the past year and a half several jurisdictions have made splendid progress in the educational field. Especially is this true in the City of Chicago where the City Sealer has developed and sponsored a program known as "Betty Budget." Mr. I. M. Levy has an excellent display of the material and characters used in this program on display at the Wardman Park Hotel. He also has samples of some of the results obtained. If you have not already examined this exhibit and discussed the program with Mr. Levy, your Committee urgently suggests that you do so before the Conference closes.

The City of Detroit and the State of Virginia are other outstanding examples. A series of visual education slides has been produced in Detroit and a motion picture made in Virginia. We are glad to announce that arrangements have been made to show some of these slides and the picture immediately following this report. This will give you some idea as to what can be done in the visual education field.

The report submitted at the last Conference by the Committee on Education invited your attention to 10 means which were being employed to spread weights and measures information. Seven of these means covered information for the public, and the other 3 referred to methods of educating the weights and measures official. 
It is the opinion of your Committee that if success is to be had in any edncational program, a definite procednre must be established. Considering the program as a whole, there appear to be three definite steps which must be observed before success can be expected:

(1) Elucation of the weights and measures ofhicial.

(2) Education of the merchant.

(3) Education of the general public.

It is believed that the order in which these steps are listed is the order that any program must follow if any outstanding progress is to be shown. In view of the feeling of the Committee along this line, this report is submitted on the theme of "Education of the Weights and Measures Official." We definitely feel that the importance of this piase of weights and measures education cannot be overemphasized.

It must be recognized that to further the weights and measures cause, in the field and in the home, requires the actual "selling" of this important public service. This brings about the necessity for good salesmanship and good public relations on the part of weights and measures officials. Consider the action of an industry-any industry which contemplates the sale of its products or services. Its salesmen are thoroughly trained in order that they can sell their products to the public. If it is necessary for weights and measures officials to be salesmen, then it is necessary for such officials to be trained. 'The training mist be broad and comprehensive, for a good salesman must be an "educator." It is not only necessary for weights and measures officials to be trained in the examination and testing of equipment; they must be trained in certain elements of salesmanship and public relations. Such a trained official will be in a position to further weights and measures administration far better than those who are not trained.

At the last Conference three means were mentioned which were being employed in the training of weights and measures officials. They are repeated here:

(1) Weights and Measures Conferences and Schools.

(2) Weights and Measures News Letters.

(3) District meetings from time to time.

Your Committee would like to add another means to the three already named:

\section{Self-Education.}

We feel that "self-education" is within easy reach of every weights and measures officer in the nation. Much material is available from the National Bureau of Standards, the U. S. Government Printing Office, the Scale Journal, the several State, comnty, and city weights and measures offices, the State and regional weights and measures associations, the equipment manufacturers, and several valuable books which have been published. At this point we would like to call your attention to a booklet prepared by the Weights and Measures Division of the State of Indiana titled "Questions and Answers." IVhile these questions and answers are based on the law and regulations for that State, a majority of the questions are applicable to all jurisdictions. If you have not received a copy of this booklet, we suggest that you contact Mr. Rollin E. Meek, Director of Weights and Measmres for the State of Indiana. Mr. Meek has informed the Committee that he will be glad to furnish copies to all those interested, free of charge. Your 
Committee has reproduced the original material which it prepared and this material is now available through the Secretary of the Committee. A weights and measure official is neither fair to himself nor to his profession if he fails to be a perpetual student.

At this point it might be well to consider a lemark made by a wellknown weights and measures official, one who is present at this Conference. He said: "An ideal inspector" is one who continually strives to increase his knowledge." This statement, within itselt, means "Self Education." Several jurisclictions have reported to your Committee that various books and pamphlets on weights and measures are made available to all men in the jurisdictions. Now, practically all weights and measures oflicials are "men." It has been said that "men" are only "overgrown boys." When we were actually boys it was necessary to make available to us various elementary textbooks. In addition to making these books available, we were required to study, in order that we might get an education. We feel that it is as important for the head of a department to properly enconrage his men to make use of the data, as it is to see that the data are available to them.

In accordance with the recommendation of this Committee, the National Bureau of Standards conducted two classes in the Calibration of Standards. The first class was held in March 1948 and was attended by 10 State officials. The second class was held in October 1948 and was attended by three State, one District of Columbia, one county, and one city official. This makes a total of 16 students attending these classes, and each recaived a certificate showing his successful completion of the colise. It is to be regretted that more jurisdictions did not find it possibie to take advantage of this rare opportunity. Every State, as well as each large county and city department should have at least one man specially trained in the calibration of standards. No doubt, the course could again be offered by the Burean, if sufficient interest were shown to justify it. Your Committee urges that you give this matter your very careful consideration and make every effort to take advantage of the opportunity for your department. If you are interested you should contact the Bureau regarding same.

Your Committee submits for your consideration the following recommendations in commection with the education of weights and measures officials. We recommend:

(1) That all laws, rules, regulations, news letter's, handbooks, etc., be made available to all weights and measures men in every jurisdiction.

(2) That a list of 200 or more fundamental questions be prepared and that all weights and measures men be properly encouraged to learn to answer these questions without hesitation.

(3) That all weights and measures men be requested to take at least two examinations each year, one examination to be based on questions referred to in Recommendation No. 2, and the other on problems which would require the use of available data referred to in Recommendation No. 1.

(4) That weights and measures men be given special training in presenting cases in court.

(5) That reights and measures men be given special training in approaching and dealing with the consuming public and the merchant.

(6) That the Bureau of Standards be requested to repeat the Weights and Measures School when the demand justifies it, and to 
further explore the field of rendering greater assistance in the actual training of State and local officials in practical field activities.

\author{
J. T. Kennedy, Chairman, \\ W. S. Busser, \\ G. E. Carpenter, \\ R. D. Thompson, \\ E. F. Usuer, \\ ROBRRT WILLIAMS, \\ Committee on Weights and Measures Education.
}

Mr. Kennedy. Supplementing the Report of the Committee, we wish to show a few of the slicles which are being used in Detroit, as typical of what can be done in the direction of visual education.

(The slides mentioned were projected at this point.)

Mr. Ken NedY. Introdnctory to the showing of the Virginia motion picture, I wish to call on Mr. Thompson, of Virginia, a member of the Committee.

Mr. R. D. Thompson. The motion picture you are about to see, which is titled, "Getting Your Money's Worth", is a project to which I have devoted much time and effort. The film has just been received and this is a premier showing; we do not know how successful it will be in stimulating interest in weights and measures on the part of the public, but we hope it will do the job.

I would ask you to remember that this file is slanted toward the consumer, and that no effort has been made to go into detail on testing methods. The film is not as comprehensive as I should have liked, but we were limited in the amount of money which could be spent on it. We were particularly fortunate to be able to have the film made through our State Department of Education; I find that a similar production made by a commercial concern would cost approximately $\$ 10,000$ while our outlay on this film has been only $\$ 1,100$.

Should any of you contemplate the preparation of a similar motion picture I shall be glad to supply a copy of our script and give any assistance possible; the experience which I have gained might be beneficial to you. Due credit should be given to the National Bureau of Standards for their assistance in the preparation of the script for this picture.

(The motion picture was projected at this point.)

The Ciraminan. I think the Committee on Education has presented a splendid Report, and I want to say that it is the desire of the $\mathrm{Na}$ tional Bureau of Standards to give such assistance as we can give and as you may find desirable or necessary in the way of further training conses or other aids toward weights and measures education.

(The Report of the Committee on Weights and Measures Education was duly adopted.)

(At this point, at 12:30 p. m., the Conference recessed for luncheon.)

\title{
TOUR OF BUREAU OF STANDARDS LABORATORIES
}

During the afternoon of Wednesday, May 25, a 2-hour tour of selected laboratories of the National Bureau of Standards was held for those attending the Conference. Delegates and guests participating were divided into small parties, each in charge of a guide.

(On the evening of Wednesday, May 25, an informal party was held at Wardman Park Hotel, the Conference headquarters, for those attending the Conference.) 


\title{
FOURTH SESSION-MORNING OF THURSDAY, MAY 26, 1949
}

(The Conference reassembled at 10:10 a. m., E. R. Fisher, Vice President of the Conference, presiding.)

\section{REPORT OF THE NATIONAL CONFERENCE COMMITTEE ON TRADING BY WEIGHT, PRESENTED BY J. H. MEEK, CHAIRMAN}

Trading in grains by weight seems to be a general practice by all agencies concerned. This condition was not altogether brought about by the Committee of the National Conference on Weights and Measures, but the committee has stimulated it in various ways.

It is recommended that all weights and measures officials encourage and assist other agencies in getting trading in grains by weight, and that Federal and State agencies interested in statistics, inspections, and market news actively support this effort.

\author{
J. H. MeEK, Chairman, \\ A. J. Jensen, \\ Erling Hansen, \\ H. K. ThatCheR, \\ J. E. Brenton, \\ Committee on Trading by Weight.
}

(The Report of the Committee on Trading by Weight was duly adopted.)

\section{CALIBRATION OF VOLUMETRIC STANDARDS}

By H. S. Bean, Chief, Section on Capacity, Density, and Fluid Meters, National Bureau of Standards

(Secretary's Note.-The presentation by Mr. Bean consisted of a demonstration of the calibration procedure recommended for large-capacity volumetric standards. A 50-gallon standard was used for demonstration purposes, and the principal operations essential to a calibration were shown, accompanied by explanatory comment. The general type of volumetric standard under discussion is illustrated in figure 9 .

Mr. Bean's remarks are not reported herein; the calibration procedure in question will be fully covered by the forthcoming NBS publication, under preparation by Dr. Judson, referled to in the remarks of Mr. Bussey on page 134 of this Report.)

Mr. Roeseler. What would be a suitable scale for checking a 50gallon prover?

Mr. Bean. A 1,000-pound scale, in good adjustment and suitably sensitive. Mr. Russell can suggest a suitable sensibility reciprocal.

Mr. Russelt. A suitable scale would be one of adequate capacity, one which is quite sensitive, and one which, above all, will repeat its weight indications regardless of the load. For such a calibration Mr. Bean or the Scale Section would not depend upon the graduations of the weighbeam, but would use the substitution method of weighing. 


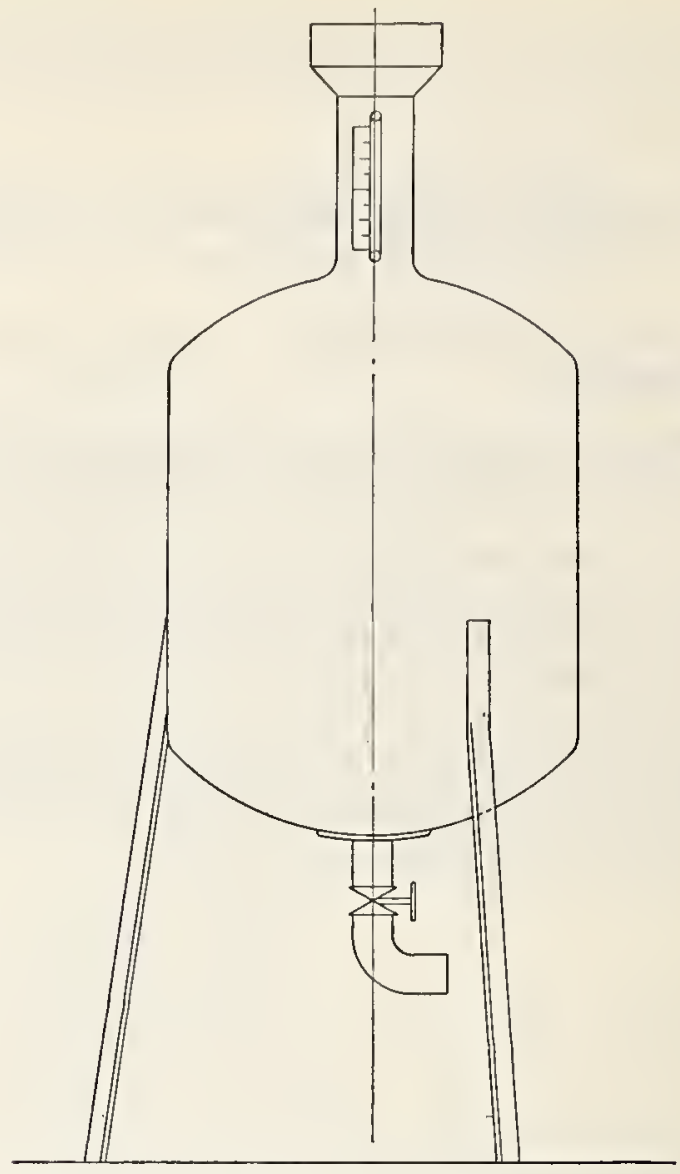

Figure 9. Typical open-type prover tank.

\section{STANDARDIZATION OF REPORT FORMS}

By R. D. Thompson, Supervisor, Weights and Measures Section, State of Virginia

The subject assigned to me for discussion is not apt to be particularly popular, as most of us have a natural aversion to report forms in general. However, they are an extremely important part of our daily routine and we naturally desire to have as satisfactory a system of records and reports in use in our jurisdictions as is possible.

Many of us are in the position of having inherited a system of records and report forms from our predecessors, and while we may desire to make a change, are at a loss to know just where to start. Our laws in most instances require that we keep records of all standards and equipment and of every official act, but do not prescribe the manner in which they are to be kept. In order that an office function as efficiently as possible, serious consideration should be given to just what information is essential and how it may be kept with the least effort.

I had for some time realized that our records in Virginia needed to be revised to some extent and approached the Burean of Standards with a request that they make a survey of our set-up and make what- 
ever recommendations they saw fit. Mr. R. W. Smith was good enough to comply and spent several days in my office going over our system and together we worked out a number of changes that I feel confident are a decided improvement. Should you contemplate changing your system, my first suggestion would be that you call on the N. B. S. for assistance. They are in a position to be most helpful, and if we ever expect to see weights and measures receive its due on the National level, we must create a demand for their services.

Let me warn you that any large-scale change in your system means work, and it is often not possible to make a complete change at one time. You will undoubtedly have some opposition from your personnel and it will take some time to get it running smoothly.

Before attempting to prepare this paper, I sent a circular letter to a number of members of this Conference asking for sample copies of their report forms, and I wish to take this opportunity to thank them for the splendid cooperation which I received. Prompt replies enclosing the requested information were received in nearly every instance.

Many of the cities and States apparently have a comprehensive system of records and reports. I do not believe, however, that I found any form in use which was an exact duplicate of any form in use in another jurisdiction. This is good, in that it shows the originality of American public officials. Some report forms struck me as being particularly good, while others did not appear to give sufficient information. The Vehicle Scale Inspection Reports showed more similarity than any other class and carried more detailed information. In many instances there was not sufficient space left on the report form to record much information, as there were too many printed captions.

It is axiomatic that no one record system would be entirely satisfactory in all of the hundreds of jurisdictions thronghout the country. Local conditions, number of personnel, and other factors would influence this. However, there are certain principles which are applicable anywhere. In setting up your record system it is well to decide just what information you will want to carry in your annual report and what statistics are necessary to present your work most graphically to the public. You must then decide the best method to procure this information. In general, it is considered an excellent plan to utilize the inspector's report as a file record, and to eliminate as much as possible the copying of information from these reports to a ledger or card index. The method of filing will depend entirely on the size and type of jurisdiction to be considered. Files for individual merchants may be desirable in large cities with subdivisions by wards, zones, districts, etc. In States this may not be feasible, but reports can be filed alphabetically by counties, cities, and towns, the chief objective being to be able to find any specific report with the least possible delay.

I feel that I must take exception to one type of report form which seems to be in pretty general use, although somewhat varied in detail. This is the form which lists a number of different kinds of devices on one side of the sheet with corresponding columns for checking whether or not the scale is approved, condemned, etc. Such a report form would seem to have little value as a record, since the only information it yields 
is that one scale of a certain class was tested and approved or rejected on a certain date. From this report it would be impossible in many instances to tell which device was referred to and no information is provided as to its condition.

In any jurisdiction carrying out a general weights and measures prograni it would seem that the following report forms would be necessary:

1. Scale Test Report.

2. Vehicle and Livestock Scale Test Report.

3. Liquid Measure Test Report.

(a) Wholesale Meter Test Report. (May be desirable in some instanees.)

4. Package Weighing Report.

5. Coal Checkweighing Report.

(i. Vehicle-Tank Calibration Report.

7. Special Report for Investigations, Proseentions, ete.

In addition to the above, other special reports are often desirable, such as daily or weekly inspector's reports, expense accolnts, reports to petroleum distributors listing faulty equipnient, etc.

I wish to devote my attention chiefly to the Scale Test and LiquidMeasure Test Reports, since these are the ones most generally in use. These forms should, I believe, in all instances provide the following information:

1. Name and address of derice owner.

2. Nake, serial number, kind of device, and eapaeity.

3. Condition (on seale's balanee eondition).

4. Disposition of equipment. i. e. Approved, Rejected, or Condemned.

5. Reasons for eondemnation.

6. Signature of owner or his agent.

With reference to " 2 " above, I feel that the make and serial number are absolutely essential, especially to the individual inspector in making his follow-up test on rejected equipment. The "kind" of scale or pump is useful information from the standpoint of your annual report. The capacity is also often of use in the office when some question arises as to a particular device.

The balance condition in which the scale is found provides a record as to how careful the merchant is about maintaining his scale in balance. This may be shown briefly as plus $2 \mathrm{oz}$, minus $1 \mathrm{oz}$, etc.

The reasons for condemmation are most important to the device owner, the inspector, and the mechanic who makes the required repairs. By use of plus or minus signs the errors in testing a computing scale, for instance, may be recorded briefly but informatively thus: "Plus 1/2 oz, $5 \mathrm{lb}$; plus $3 / 4$ oz, $15 \mathrm{lb}$; plus $11 / 2$ oz, $30 \mathrm{lb."} \mathrm{On} \mathrm{a} \mathrm{gasoline}$ pump the notation might read as follows: "Minus $10 \mathrm{cu}$ in., 5 gal. Replace glass over dial, repair antidrain nozzle, price per gal not legible."

Having the signature of owner of device on the report provides proof positive that he received the report and was informed as to the condition of his equipment.

The "kind" of scale seems to be one of the most difficult matters to clarify and there is much overlapping on many of the report forms currently in use. For instance, most of these forms list beam, platform, and counter as separate classifications for scales, hence the question may be properly asked, "Where would a counter platform scale with a beam be listed?" Apparently the best solution to this prob- 
lem is to establish about six rather broad classifications based somewhat on the general use to which the device is put.

Now, some of you may get the impression that I have a bookkeeper's or auditor's complex and that what I suggest will cause a lot of extra writing and trouble for the individual inspector. This is not the case; what I propose is the designing of report forms in such a manner that if properly made out in a concise manner they will provide the maximum amount of information.

I am here reminded of the story about the young graduate in business administration who was fortunate enough to secure a job as timekeeper in a lumber camp during the depression. The employees at the camp consisted of 100 lumberjacks and 2 women cooks. Being chockfull of ambition and information, the timekeeper started sending his boss very voluminous reports on the activities at the camp. He shortly received a wire which read as follows: "Too busy to read long reports, be brief." It so happened that one of the lumberjacks about this time married one of the cooks, so in his next report the timekeeper stated " $1 \%$ of men have married $50 \%$ of women." This, I believe, proves my point that a report may be brief, but informative.

Now, as to check weighing packages, this form may be quite simple in design, but should provide the following information:

1. Name and address of merchant or manufacturer.

2. Name of commodity.

3. Name and address of packer.

4. Number of packages weighed, number short, number over, average error.

5. Approximate number of packages in lot checked.

With this information the office would be able to take up any shortage with the merchant or packer in an intelligent manner.

I would like to stress here the importance of complete and accurate records on check weighing. I believe that in many instances inspectors actually do a great deal more work than they record. Of course "the work is the thing," but if we are to obtain proper recognition of our" accomplishments we must maintain proper records so as to present them to the public in the best manner possible. It must also be admitted that there may be some jurisdictions or individual inspectors who claim credit for more work than is done. Either is bad; as weights and measures men we are "disciples of accuracy" and as such we should be able to prove all figures which we release.

On complaints and special investigations a formal report stating full details should be made out for our files; all correspondence and other documents pertaining to it should be filed together.

In conclusion, let me reiterate that as public officials it is most important that we maintain complete records of all official acts.

\section{QUANTITY DECLARATIONS ON PACKAGED SOAP PRODUCTS}

\section{REMARKS OF J. A. BERNARD, COMMISSIONER OF WEIGHTS AND MEASURES, CITY OF ST. LOUIS, MO.}

When I was given this assignment I accepted it with some hesitancy, because to my knowledge this subject has never been discussed to any great extent by this Conference. Unfortunately there is very little material, so very little factual data upon which to base a fair and just opinion. That it presents a problem of sufficient importance is obvious from the fact that it has been requested that it be presented to this 
Confelence for discussion. Many open questions are apparently controversial. The general consensus of opinion among weights and measures oflicials all over the country seens to be that there should be quantity declarations on packaged soap products as well as bar soap. This problem is not a simple one and should be approached by the soap industry in cooperative spirit, as well as by the weights and measures officials who are interested in protecting the public from any misleading practices on the part of industry witl regard to weights and measures.

Industry in general, like individuals, will tend to take the path of least resistance and will oppose regulation, and naturally so. In our economy of free enterprise, industry is entitled to a fair profit and it is not our intention to disturb this economy. We are only interested insofar as it affects the phase of quantitative declaration. Arguments will be presented to show impracticability or impossibility of such regulation as well as increased cost to the consumer. This problem can only be considered by us in the light of greater or less benefit to the consumers.

It has been pointed out that "laws are made not for the protection of experts, but for the people, that vast multitude, which includes the ignorant, the unthinking, and the credulous who, in making purchases, do not stop to analyze but ale governed by appearances and general impressions."

A weights and measures official is in no wise a technical expert. His knowledge of the manufacturing of soap is more or less limited, and he can only cone to fair and just conclusions by having sufficient factual data. 'This may only be obtained by having the means of research and proper facilities. Most cities and States do not have these facilities.

One of the main ingredients of soap is water, which is the controversial matter in this discussion. Water, of course, is necessary in the manufacturing of soap and remains to a greater or less degree in the finished product. Its evaporation is the crux of this problem. However, there are other commodities where similar conditions prevail that are regulated as to net-weight content. Packaged soap products can be controlled more easily than cake or bar soaps that are not distributed in evaporation-retarding wrappers. Hence there is a greater resistance on the part of the soap industry to making a quantity declaration on cake or bar soap.

We also grant that the amount and percentage of water vary greatly with the types of soap, the ingredients used, the purposes of the soap, the methods of manufacture, and according to many items in different brands. In order to arrive at a reasonable solution it will be necessary to know the causes for these differences. I believe that the soap industry with its facilities for research will have to work out this problem.

At this point it may be interesting to note the results of a survey made by the Weights and Measures Division of the City of Fort Worth, Texas, pertaining to the evaporation of excess moisture in various brands of soaps. This report was made available to me by Mr. W. R. Hardy, Sanitary Engineer of Fort Worth.

In order to obtain factual evidence a number of bar's of soap, representing different sizes and makes, were purchased from retail outlets. Two bars of each type of soap were purchased and after checking the 
net weights, which were identical, one of the two bars was unwrapped; then, all the soap was stored in a storage room located on the top floor of the City Hall building. The temperature of this room is normally high in comparison with the normal room temperature for the remainder of the building and there was no forced ventilation. Periodically the bars of soap were reighed and here are listed some of the results. The test is not all inclusive since a considerable number of bars were not available for weighing at the time of the last check. The different brands of soap are indicated by letters.

\begin{tabular}{|c|c|c|c|c|c|c|}
\hline Name & $2-25-48$ & $\begin{array}{c}\text { Net } \\
4-1-48\end{array}$ & $\begin{array}{l}\text { Teight } \\
6-9-48\end{array}$ & $4-4-49$ & $\begin{array}{l}\text { Total } \\
\text { Lost } \\
\text { IVt. }\end{array}$ & $\begin{array}{c}\text { Total } \\
\text { Lost }\end{array}$ \\
\hline & Ounces & Ounces & Ounces & Ounces & Ounces & Percent \\
\hline - Wrapped - - & $\begin{array}{l}9 \% 4 \\
9^{5 \%}\end{array}$ & $\begin{array}{l}93 / 8 \\
9^{33}\end{array}$ & $\begin{array}{r}9 \\
83 / 4\end{array}$ & $\begin{array}{r}83 / 2 \\
7^{23} 32\end{array}$ & $\begin{array}{r}1 / 44 \\
1^{29 / 32}\end{array}$ & $\begin{array}{l}12 . \\
19 .\end{array}$ \\
\hline d. . . & $95 \%$ & $8 \% 16$ & 8 & $7 \% 16$ & 2316 & 22. \\
\hline & 3 & & $37 / 16$ & & & \\
\hline - & $3^{1}$ & 37 & $3^{13 / 32}$ & $3^{5} / 16$ & $3 / 16$ & \\
\hline & $8^{3}$ & & & $81 / 1$ & $11 / 18$ & \\
\hline D- & $8^{3}$ & $8^{3}$ & $81 / 8$ & $73 / 4$ & 1 & 11. \\
\hline- & $33 / 8$ & & $3 \frac{5}{16}$ & $3^{1 / 4}$ & & \\
\hline -Unwrappe & $3 \frac{3}{8}$ & $33 \%$ & $3^{5} / 10$ & $3 \frac{1}{4}$ & & \\
\hline
\end{tabular}

It is noted that the loss of weight is high for certain types but the difference in loss between the rrapped and unwrapped soaps was very little. In fact, there is no difference in lost weight for two brands of the soaps. While this test was not conducted under laboratory conditions or control and while it may not be considered irrefutable, it leads nevertheless to certain conclusions. Obviously, the soap that loses considerable weight by evaporation contains an excessive quantity of water.

We are all concerned with the quantitive phase of soap, yet because of its excessive moisture content, it is difficult to get its constant. But the consumer certainly does not know whether he buys too much water or not. As reights and measures officials, we are only concerned with the net weight of the item. Quality determination does not come within our jurisdiction. Hence, we cannot consider an excessive amount of water in soaps in our discussion, except insofar as it relates to the net weight of soap. Another factor to be considered is the air in the cake or bar-the case of floating soap. In both cases the size of the merchandise doesn't give any indication of the amount of actual soap purchased.

I would not propose to support the quantity declaration by allowing a tolerance, knowing that many weights and measures officials would oppose it. They are against commodity tolerances, and I join with them. Thus, I believe that it will be up to the soap industry to find a way to regulate the amount of moisture and to develop evaporationresistant wrappers. It has been contended that the soap industry could, through its research laboratories, approximate very closely the water content of the various soaps and the rate of evaporation. Allowances could be made for such shrinkage by making the cake or bar sufficiently large so that the quantity declarations at time of sale to consumer would be accurate. Whether or not this would be practicable would depend upon what experimental tests would show. I am of 
the opinion that any additional cost incurred would be more than compensated by the increased benefit to the consumers. Nor do I hold to the argument that quantitative declarations would confuse the public. But the consumer is confused by the highly competitive advertising of the soap manufacturer. The many brands, sizes, and types of soap containing perfume and other noncleansing ingredients also tend to confuse the buyer.

Of course, soap is now sold everywhere by the cake or bar and by numerical count rather than by weight. I realize the difficulty of making changes in trade customs and buying habits. But I think that it would be worth while to make the effort. It would lead to the only fair solution for the housewife to determine for herself what she is getting for her dollar's worth. And after all, it has happened before that commodities formerly sold by measure or count are now sold by weight. Think of fruits and vegetables.

We weights and measures people are not technical experts in the various industrial fields. Our job is to apply the factual data given to us to weighing and measuring. It is not up to us, not having the necessary facilities, to decide whether new procedures can be applied or not. But we feel that an independent agency-perhaps the $\mathrm{Na}$ tional Bureau of Standards-should be asked to make a comprehensive study of the whole problem to make available to us sufficient factual data upon which to formulate a fair and just policy.

REMARKS OF R. W. PEET, MANAGER, ASSOCIATION OF AMERICAN SOAP AND GLYCERINE PRODUCERS, INC.

I would like to identify myself somewhat before talking on the subject because I believe my background entitles me to speak to you with some degree of knowledge and authority on the subject of bar soaps.

I was with the Colgate-Palmolive-Peet Company, or one of its predecessor companies before they merged, for thirty year's. Five years of this time was spent in selling the retail trade where I got to know the man at the counter and to see first-hand his close relationship to his customer-usually the housewife. During the last five year's, I was vice president and had responsibility for the Research Department.

I appear before you today as Manager of the Association of American Soap and Glycerin Producers, Inc. This organization has a membership of about 190 manufacturers spread geographically across the country. Among our membership are not only the largest but obviously a great many of the smallest. Many, if not most, of our members manufacture and sell bar soaps and consequently are interested in your discussion.

I would like to mention the fact that the 1947 recommendation in reference to net weight on bar soaps refers to a method of sale rather than a marking requirement. I assume that it was not intended by this recommendation to require the sale of all bar soaps at so much an ounce and that the recommendation was intended to require that bar soaps should be marked with the net weight-the product still being sold at so much per cake. I am, therefore, treating the recommendation as one relating to marking only.

I believe I have a reputation for being liberal rather than conservative in my thinking so that I appreciate the objectives for which 
you men are striving, and I would like to express appreciation for the time and thought which have been and are being given to our product problem by Mr. Rogers, Mr. Blickley, and others on your Committee on Methods of Sale of Commodities.

We have many points of view which are identical or very close. Just to name a few: Neither they nor we maintain that present methods are right merely because they exist. If new methods of sale would actually benefit the consumer, we all agree a change should be made; conversely, we agree that a nuisance requirement which does not benefit the consumer would be undesirable. Thirdly, we are both in agreement, I believe, that soap is unusual in the high variation of moisture content present at the time of manufacture; this is due to different kinds or types of soaps and different processes and equipment used in production. Fourthly, I think we all understand that a very large variation of moisture content exists in the same brand at time of consumer purchase due to variations in the age of the product, storage conditions it has been subjected to since manufacture, temperature, and humidity conditions while in storage or shipment, etc. All of these conditions are affected by such things as age of the product, type of store selling the product, geographical location of factory, warehouse, and store, season of year, economic conditions in the country during the previous year or two, etc.

So it becomes our joint concern to weigh the facts and to determine any probable benefits versus probable hardships or the probability of ending up with merely a nuisance regulation. Now looking at the facts let's consider the kinds of bar soaps and their moisture content.

\section{Moisture Varies at Time of Manufacture}

Basically, the problems that arise in considering the proposed requirement grow out of the fact that bar soaps have of necessity a certain water or moisture content. Weights and measures officials, who have had opportunity to study this matter at first-hand, realize something of the scope of this matter of moisture. For the benefit of others, let me briefly give you some facts on moisture in bar soaps.

Milled Toilet Soap.-Most perfumed toilet soaps are referred to as "milled." This type includes such soaps as Palmolive, Lux, Camay, Sweetheart, and many other's. 'The term "milled" means that the soap undergoes a processing of milling and compressing, which is roughly equivalent to kneading and rolling of bread. The result is a finely homogenized finished product. For these operations, the material must have a certain amount of plasticity which is imparted to it by water. Furthermore, molding and stamping the finished bar efficiently and cheaply would be impossible without this plastic quality. When this type of soap is ready for shipment, the moisture ranges from 6 percent to 15 percent. The Federal Soap Specification, $\mathbf{P}-\mathbf{S}-$ 621 , for milled soaps allows a maximum moisture content of 15 percent.

Cold-Made Toilet Soap.-In addition to the milled toilet soaps, there is a type of toilet soap which by reason of the particular manufacturing process used is called "cold-made." In this type the moisture content is higher and has a range from 19 percent to 26 percent.

Ordinary Laundry Bar Soap.-Soap of this type includes such brands as Fels Naptha, Octagon, Kirkman's, American Family, P \& G 
White Naptha, and many others. Processes through which it goes are less complicated but here, too, a minimum water content is required. Huge blocks of soap weighing about 1,000 pounds, formed when the soap from the kettle is allowed to dry about a week in frames, are cut into slabs, and then into bar's. A dryer product could not be so handled. 'The moisture content in finished bars of this type ranges up to about 40 percent. Federal Soap Specification P-S-591a allows a maximum of 36 percent.

White Floating Soaps.-Soaps such as Irory and Swan are made by still a different process. and other floating soaps use still another. In imparting to the soap its ability to float, a definite water content must be present. The range is from 20 percent to 34 percent-Federal Specification P-S-616a allows a maximum of 34 percent.

In short, the range of moisture content in bar soaps varies from 6 percent to 40 percent at the time of production. Please keep these figures of 6 percent to 40 percent moisture content in mind because they are basic to an understanding of the problem. This wide range is not an arbitrary decision of the manufacturer, but depends on (a) Type of soap, (b) Process of production, (c) Equipment available, and (d) Kind of fats and oils and other raw materials used; so that bar soap is a complex rather than a simple commodity.

\section{The Net Weight of Two Bars of a Single Brand may Vary Widely at Time of Consumer Purchase}

After soap leaves the factory, it is subject to numerous conditions which affect its loss of moisture and consequently its net weight. Temperature and humidity are obvious conditions and since they affect our own personal comfort we all know how they can vary. But there are conditions other than weather conditions which produce the same end results in bar soaps. Was the warehouse heated and to what extent? If in summer was it hot and how about air circulation? Was any particular shipping case in the middle of the pile where it is better protected or was it on the outside of the pile where it gets the full treatment? Was an individual bar in the middle of the box or on the outside? The inside bar is kept more uniform of course.

Is the prodnct wax wrapped or wrapped with plain wrapper or not wrapped at all? Each affects the moisture loss. And one of the greatest conditions and variables is of course age and time of exposure to various conditions of temperature and humidity. A single box will vary tremendously in its time of storage at the factory. At the time of manufacture no one knows where it is going or through what channels nor how long before it will be bought by a consumer. I have seen conditions where a 12-month stock was in the hands of the wholesale and retail trade. Economic conditions generally as well as competitive conditions both play a part in making this age factor a variable. Channels of trade, whether direct from factory to a retail market with a quick turnover, or from factory to wholesaler or jobber to retailer, make a big difference. Drug stores, grocery stores, department stores, and syndicated stores differ widely in their rate of turnover compared with stores in their own class, let alone with other classes. So that when the consumer buys the product it is very understandable that there may be a variation of 20 percent. Twenty percent is not an extreme range. 
A bar of ordinary laundry soap which contains 35 percent moisture at the time of manufacture may easily dry out to 5 percent moisture at the time of consumer purchase if it has met unfavorable marketing conditions such as a long time in storage, a long time on the retail shelf due to new soaps being constantly placed in front of it, or a store with a low turnover, stored near a radiator, the wrapped bar being placed on display in a window exposed to sunlight. Thus, we may have a variation of 30 percent of the manufactured weight. If a bar weighs 10 ounces at the time it is produced it may weigh as little as 7 ounces at the time the consumer purchases it in the retail store. But again it may weigh $91 / 2$. No one can tell at the time it is produced what it will weigh at time of consumer purchase because no one knows the conditions it will meet nor how long it will be before the time of consumer purchase.

\section{How Can a Bar be Marked?}

The manufacturer, if faced with a regulation which says he must mark the bar or wrapper with net weight, faces two alternate principles of marking. The first assumes favorable conditions for his product in all cases. He may mark his 10 -ounce product " 9 ounces." Howevel, some bars may weigh only 7 ounces, and the range will be from 7 to more than 9 ounces. It is certain that he will violate the law, not occasionally but constantly. His other alternative is to assume unfavorable conditions for his product and mark an anhydrous or dry weight of 7 ounces. Now he is safe but most of his product will be sold at a net weight well above the marked weight.

\section{What is the Result?}

If he marks 9 ounces, the consumer will all too frequently find the product weighs less than 9 ounces, and will believe she has been cheated. She will complain to her retail store, to the weights and measures officials, and to the manufacturel. And when I say "she" I really mean "they" - thousands and thousands of "she's". And the result will be chaos and confusion caused by fruitless investigation. Invariably, the answer will lie in the unhappy faculty of water to evaporate. The problem will probably really be, "That primarily caused the evaporation in this particular case?" The retail store may be placed in an unfavorable light because she may compare his weight with the weight of the same product in another store. Maybe the first store is a small independent dealer with a slow turnover and the second is a large chain or super-market with a fast turnover. There may easily be a regular difference in weight between the same brand in the two stores and she will turn to the dealer with the faster turnover. The reights and measures official, either because of complaints or as a matter of routine, will check the actual weight against marked weight and if he finds a variation of 20 percent or more, would certainly feel that prosecution was in order.

You gentlemen know the consumer and you know yourselves well enough to know that the manufacturer will always hear about the bars which were underweight. The complaints will always be in regard to the unusual case-not the ordinary or average condition. 
If one-fourth were above weight, one-half the exact weight, and onefourth below weight, 100 percent of the complaints would come from the 25 percent below marked weight.

It would be a long, slow, and painful process for everybody before reights and measures officials became educated or reconciled to the fact that a leeway of 20 percent or even more would have to be permitted in the net weight of bar soaps. The manufacturer would be in a constant state of explanation and laborious education with both consumer or weights and measures officials. On the other hand, if the manufacturer takes the other alternative, and marks an anhydrous or dry weight, the variation will be on the other or plus side and the marked weight will have no resemblance to the real weight in most cases.

\section{Who Benefits?}

Under such circumstances, it is not a benefit to the consumer to mark bar soaps with a net weight. Neither she nor a weights and measures official can check actual against marked weight and know whether she is being short-changed or not. The certain result would be endJess confusion and irritation until the regulation would fall by sheer weight of its own impracticability. If the other course is pursued and the bar marked with the dry weight, likewise the marked weight becomes meaningless because it bears no resemblance to reality in most cases. Thus, a net-weight marking on bar soaps is truly a nuisance regulation benefiting no one.

\section{Soap is Different}

Bar soaps are unique in respect to the moisture factor because they are the only product which has all of the following three qualities:

1. A bar of soap is sold by the unit. No box is needed to hold it together. This makes it different from flour, sugar, etc.

2. Bar soaps are sold in a wide variety of retail outlets, including grocery stores, drug stores, department stores, syndicate stores, variety stores, and country general stores. Few other products are so generally distributed. The channels of distribution from factory to store are consequently complex and varied.

3. Bar soaps have a high moisture content yet moisture is not an important factor to the housewife in buying soaps. In many other products, loss of moisture impairs the efficiency or lessens the value. With bread, for instance, which also has a high moisture content, she feels the loaf and if it has dried out she knows it is not fresh and will not buy it.

\section{Weight is no Measure of Value in Bar Soaps}

The consumer buys soap to use with water in washing anything from skin to dirty overalls. It is the cleaning power of the product she is after, and I cannot overemphasize the fact that this remains monchanged in the product no matter whether it is freshly made or whether it has dried out completely. It is to be used with water and the sudsing quality and detergent efficiency remain unimpaired regardless of moisture content. Bar soaps have not been sold by weight since the advent of brand names. They have been bought by the bar 
or cake on the basis of odor, color, detergent ability, gentleness on the hands, and lasting quality, and not on the basis of weight. To try to change this is not to progress-it is to go back to the days of our grandmothers. Weight is no measure of value in bar soaps.

\section{Unwrapped Soaps Are Sold in Competition to Wrapped Soaps}

The regulation to mark net weight on bar soaps would apply to wrapped soaps and yet the same type of product sells competitively unwrapped. There certainly would be confusion and unfairness in such a differentiation. One might assume that the tendency would be to drive the protective wrappers off of bar soaps to get away from the annoyance of complaints. This would certainly be a backward step.

\section{Sale by Numerical Count Fulfills Requirements of State Laws}

Most States carry laws which say in effect that the net quantity of the contents of a package be conspicuously marked on the outside of a package in terms of weight, measure, or numerical count. The consumer is accustomed to buying bar soaps by the unit and we believe the manufacturer is within his legal rights if he refused to put a netweight marking on his wrapper. I think any court in hearing a test case would, after reviewing the facts just recited, rule in favor of the manufacturer that he was complying with such a law.

\section{Conclusion}

In conclusion, gentlemen, let me urge that you keep in mind:

1. That soaps differ in moisture content from 6 to 40 percent at time of manufacture.

2. That this loss does not change the cleansing powers of the bar as originally produced.

3. That loss of moisture varies, depending on age and other conditions.

4. That there is no way for the manufacturer to mark a net weight and be reasonably accurate-a variation of over 20 percent must be expected.

5. That soap is unique in that weight is not a measure of value or' performance.

6. That instead of the consumer being benefited and protected by net-weight marking she will be misled and confused.

7. That the manufacturer will be put to endless trouble trying to explain numerous individual cases revolving around moisture evaporation.

For these reasons, we think it would be a grave mistake to make a recommendation that bar soaps be marked with a net weight and we most earnestly urge that this body with its present prestige forego making such a recommendation which, if adopted and if put into practice, would result in so much confusion, exasperation, and hardship.

Mr. Beckrr. Does soap improve with age?

Mr. Peiza. You are asking me, and I can ask a good many people and get a good many different answers. The reason most people remove soap wrappers-and many people do do that-is that the bar 
becomes harder as the moisture dries ont, and when the bar is put into water it dissolves less rapidly. There is no question that the bar will last longer if the wrapper is removed and the bar dried up. 'The other side of the question is that it takes a little longer to make a lather from the dried-out bar.

Mr. G. W. WARNer. As I understand it, if the Conference were to decide that bars of soap should be marked with their net weights, you would not want that to carry over in to the advertising.

Mr. Pent. Quite obriously, it could not carry over into the advertising. As I have pointed out, we just do not know any way to mark a net weight and be even reasonably accurate. If you were to advertise weight, I presume that it would come down to a price per ounce, but if you have this large variation at the time the consumer buys it you simply cannot empliasize the weight and get her to understand it, and she will take it home and weigh it and insist that she has been cheated. If it were practical to do it and avoid large discrepancies, perhaps some retailers would sell that way, but my prognostication is that no matter what the Conference does in regard to net weight, soap cannot be sold that way any more than it can be marked accurately that way.

Mr. BAKEr. Would it be practical for the manufacturer to evaporate the moisture before the soap leaves his plant rather than to let the product evaporate on the merchant's shelf?

Mr. Pres. If the manufacturer tried to do that in his plant, he would have to increase tremendously his inventory and live stock in his plant. I know that no manufacturer would be willing to add to his overhead expense to build the warehouses that would be necessary to do that. I think there are some 400,000 grocery stores in this country besides the drug stores, variety stores, syndicate stores, department stores, and so on. The manufacturer would have to build the equivalent in storage space of the space devoted to soaps in all those outlets. It just would not be practical.

Mr. BAKEr. I grant that. But would it not be possible to utilize an accelerated drying process of some sort?

Mr. PEeT. The soap industry is not trying to avoid weight mrking. Exactly what you suggest is being done with packaged soaps; these may be dried in a tower three or four stories high by blowing hot air through the product, producing a product of about 12 percent moisture when it is packaged. Invariably the net weight is marked on such a package. Another process of drying is used for chips and flakes where the hot soap goes onto a cooling and chilling roll, making it thick and viscous, after which it is scraped off and put through rollers and a series of dryers in the form of very thin ribbons, the moisture being evaporated so that when ready for packaging the product is relatively anhydrous.

Those are the methods which the industry uses to do what you suggest, but you end up with a packaged product. If the product is in solid cake form, it is obvious that you can only get at the outside of the cake; you cannot dry it inside as you can in the case of a fine product in ribbon, chip, or granule form.

Mr. Batconr. Is there any objection to labeling bar soaps by numerical count, even in single units? The weights and measures law requires that any commodity in package form be labeled to show net 
contents in terms of weight, measure, or numerical count. Labeling by count might provide a compromise which will meet the legal requirements and avoid umecessary expense.

Mr. Pret. I certainly agree with your thought part way. There are consumer packages containing 2 or 3 or 6 or 12 cakes in a single containel'; it seems to me that it would be proper for such a container to be marked with the number of cakes in the container but in the case of the more usual one-cake wrapper it does not seem to me that anybody benefits by having the wrapper" marked "one cake." Everybody knows it is one cake and there is no confusion in the mind of the purchasing public.

Mr. Baucon. However, the container may be a box containing a very small cake, and the consumer cannot see whether the box contains one cake or several cakes. It is a blind package. The might require that when soap is in package form it shall be so packaged as not to deceive the purchaser as to its quantitative value.

Mr. PeEr. I can see some practicability to your suggestion that the sale be on the basis of numerical count and that the package be not deceptive as to the count.

Mr. Crawrord. Have you any ideas on the practicability of selling soap on the basis of its cubical content?

Mr. Pret. That was discussed by us with your Committee, but I do not see that some such marking as "2.75 cubic inches" would mean anything to the consumer. I think weight woukd mean more to her, but I think the cake itself is the thing that she is used to and understands, and that is practical in the industry.

Mr. Crawford. What about uniform dimensions?

Mr. PeET. 'The high-moisture-content laundry soap shrinks a great deal and so does the old-fashioned type of floating soap; the newer type floating soaps do not shrink the same way but they do dry out and get smaller and they do become warped. Personally I do not think that your suggestion would help the situation and that, if anything, it would make it more confused.

Mr. Roeselur. If each bar were marked by the manufacturer to show its net anhydrous content, would this not give the consumer a much better idea of the amount of soap she was buying?

Mr. Pecr. 'That would eliminate the water, but would not, I believe, comply with the State laws which I am familiar with and which relate to the net weight at the time of consumer purchase. If a bar weighing 10 ounces at the time it was produced was marked on an anhydrous basis to show a weight of "7 ounces" that might protect the industry against a charge of cheatiug, but actually the consumer would actually receive a bar weighing perhaps $81 / 2,9$, or $91 / 2$ ounces, and the net-weight declaration would not have any practical value that I can see.

\section{REMARKS OF MR. ALEX PISCIOTA, FORMER DIRECTOR OF THE BUREAU OF WEIGHTS AND MEASURES OF NEW YORK CITY}

The Chamrin. I understand that Mr. Alex Pisciota, formerly in weights and measures work and now a magistrate in New York City, is visiting the Conference and will have to return to New York City very soon. We shall be glad to have a few remarks from $\mathrm{Mr}$. Pisciota.

Mr. Piscrota. I am certainly very happy to pay you a visit after being away from weights and measures work for about 8 years. I 
can earnestly and sincerely say that I miss that work a great deal, and that this visit brings back many pleasant memories. As new problems constantly arise the weights and measures officer can say to himself at the end of each day, "Today I have accomplished something." I am glad to see that so many of the old-timers are still active. Many of the new men I do not know at all. Some of the active fellows who were with us before have passed away or retired from the work, but weights and measures is the grandest job in the world, and weights and measures officials are the grandest bunch of fellows. They are sincere and honest and really have the interest of the general public at heart. Good luck to you and Godspeed.

\section{UNIFORMITY OF INTERPRETATION AND ENFORCEMENT}

\section{By L. E. WiтT, Sealer of Weights and Measures, City of Mitwauliee, Wis.}

"Uniformity of Interpretation and Enforcement." The subject is broad and it is of extreme importance to weights and measures officials and to industry as well. The topic would seem to present some difficulty in the matter of developing material inasmuch as the whole subject is completely expressed and self-described in the all-inclusive title.

Uniformity of interpretation and enforcement is something which all weights and measures officials should and do strive to ultimately attain and effect-that is one of the prime purposes for the convening of this National Conference on Weights and Measures. This is the $34 \mathrm{th}$ meeting of weights and measures officials, representatives of many and varied industries, and other interested persons, from all sections of the country, who have formed and participated in the deliberations and actions of this association, known as the National Conference on Weights and Measures, under the sponsorship of the National Bureau of Standards, with the basic idea of developing codes of specifications and tolerances which might be recommended for general adoption, thus providing an opportunity and means for uniformity among the States in this very important regard.

The topic may properly be considered as consisting of two parts: (a) uniform interpretation and enforcement of specification requirements, and (b) uniform regulations promulgated under weights and measures laws. This approach and break-down of the subject was evidenced in Mr. R. W. Smith's correpondence with me when assignment of this item for this year's program was made by the Secretary of the Conference. Such interrelation of the two topics was further indicated by the instinctive and natural reaction of the several weights and measures officials to whom I addressed letters of inquiry requesting statements of their viewpoints. For the purpose of this discussion, then, it would seem that the speaker is within the scope and limits of the topic assignment when discussing interchangeably Specifications, Tolerances, and Regulations.

Specifications, Tolerances, and Regulations ordinarily deal with the mechanical instrumentalities of weighing and measuring. Specifications are concerned with design and construction, materials and workmanship. Tolerances are the limits of variations from the true standard of performance or value which will be permitted by the official when he tests commercial weighing and measuring devices. Regula- 
tions relate to the use or maintenance of commercial devices. The foregoing statement describes Specifications, Tolerances, and Regulations with respect to devices themselves, as such. On the other hand, in many weights and measures jurisdictions, regulations are promulgated, as occasion arises, when it becomes necessary to clarify existing weights and measures laws; these regulations do not relate to the use or maintenance of devices-they relate solely to the sale of commodities and/or more specifically to the methods of sale of commodities.

I have in mind, for example, the marking of packages, the exemption of so-called small packages from markings as to weight, measure, or numerical count, and many other matters which are handled by regulation in the various States. A few specific instances are cited to you herewith :

A cord of firewood is universally described as being 128 cubic feet. It is assumed that the wood is piled in a rack measuring 4 feet by 4 feet by 8 feet and that the pieces of wood are 4 feet in length. When the consumer wants to purchase shorter lengtlis, such as 1-foot, 16-inch, or 2-foot pieces for stove use, he is sold by the dealer "one-cut," "twocut," or "three-cut" wood, or in some localties "single cords," "running cords," or "quarter cords" (the latter being 1-foot lengths).

Theoretically, when the dealer fills an order for such cut wood, he racks a cord of wood in 4-foot lengths and then saws it to the customer's order. Such cut wood, as you know, will not rerack to 128 cubic feet after it is cut. The customer frequently reracks this stove-size wood after purchase and then makes complaint to the weights and measures official that he has received short measure. You will recall that during the war the O. P. A. issued a number of directives in various parts of thie country with respect to cut cord wood. Many of these rulings by an agency with national authority varied considerably in different sections of the country. Further, several of the States established a fixed figure of 15 percent as the normal shrinkage to be allowed when reracking and remeasuring cut cord wood of all sizes.

Many large dealers buy and have shipped to them in carload lots cord wood in various lengths-1-foot, 16-inch, 2-foot. They frequently request the weights and measures official for information as to what constitutes a cord or a fraction of a cord of wood in such lengths. Some States have established or fixed by regulation what the cubic measurement of cut cord wood shall be; other's have not. There are many variations.

If the National Conference on Weights and Measures were to adopt a model regulation to govern this specific commodity, it would serve as a guide to weights and measures officials all over the country. If such model regulation were universally used as a basic guide for measurement and if it were enforced, there would be uniformity of interpretation and enforcement-uniformity which would benefit consumer and dealer alike.

Another example is the sale of tomatoes in cartons topped with cellophane. Federal laws and regulations and many State laws and regulations would seem to require no marking when these cartons contain (as they usually do) four tomatoes which may easily be seen and counted through the cellophane top of the cartons. These packages would qualify as "small" packages. However, during the war the 
OPA issued a directive that tomatoes when sold in this kind of package would requine a declaration of the net weight of the contents. It is my belief that in many States this requirement obtains at the present time. I have also seen some of these cartons which were not marked as to the net weight of the contents, but they did bear the statement "4 tomatoes." In the State of Wisconsin, and in my own local city jurisdiction, a carton of four stomatoes with a cellophane top is considered a "small" package and need not be marked as to its net weight or numerical count.

This does not close the matter as far as I am concerned, however. We have in the city of Milwankee several large lithographing and color-printing companies which manufacture labels, cartons, and wrapper's which are sold to customers in all parts of the country. The attorneys for these companies not infrequently call on our office for information concerning the requirements for marking packages of tomatoes - this to insure that thousands of cartons, wrappers, and labels will be acceptable to the various jurisdictions where they are to be used. Mistakes, omissions, or improper marking in the printing of this material would result in some very high-priced scrap paper, which somebody would have to pay for. If the National Conference on Weights and Measures were to adopt a model regulation with respect to this commodity and if the model regulation were promulgated by the various States, it would be a simple matter for the weights and measures official to furnish industry with proper and accurate information concerning the method of sale of this specific commodity in all parts of the country.

The city of Milwaukee is a very large market for the sale of pickled or spiced herring in glass jars. Shortly before the war the wholesale cost to the retailer was approximately 30 cents for a 1-pound glass jar. The principal ingredients of the pickled herring were herring and onions. The fish cost the packer approximately 20 cents per pound, while the onions cost him approximately 3 cents per pound. Competition was at that time already very keen among the local packers and processors, but the situation was aggravated by the fact that a number of out-of-State packer's were entering the Milwaukee market for this commodity. Price is of course a competitive factor at both the wholesale and retail level. As competition for business became keener, price competition was made and/or met by the simple expedient of putting more 3 -cent-per-pound onions and less 20-cent-per-pound herring in the packages. The markings as to the net contents of the whole package easily met the requirements of Federal and State laws because the contents were all edible and the packages were marked with the true net weight of the contents. The situation reached a point where the bottle or jar would contain an outside layer (which showed through the glass) of choice fillets of herring but the inside of the package would contain a large tightly-wadded center of onions. The customer who was paying for pickled herring was definitely being cheated, to put it objectively and bluntly. The onions, instead of being an incidental ingredient, were the main ingredient in the package. Our State Department of Agriculture thereupon held hearings in the matter and then promulgated a regulation governing the sale of pickled or spiced herring which required the container to have marked on the outside thereof the "net weight of fish." The local packers and processors 
promptly changed their labels to meet this requirement, while out-ofState packers supplemented their regular labels as to net weight of the contents of edible food (which were legal in interstate commerce) by the addition of another label which stated the net weight of fish on all packages of this commodity which were shipped into and sold in Wisconsin. The regulation worked a hardship on no one, but it did eliminate an abuse which had become intolerable. Further, and very important, it placed all of the packers on the same competitive basis.

Such a regulation, based on actual experience in the matter, could very well and properly be adopted by the National Conference on Weights and Measures as a model regulation.

Another item which will soon pose troublesome problems for weights and measures officials is the sale of liquefied petroleum gases. Confusing and possibly deceptive terms which various companies use in billing their products to their customers could no doubt very properly and effectively be the subject of a model regulation adopted by the National Conference, basing the regulation on the experience in the various States where this type of commodity is extensively sold.

Other commodities or items which would possibly require special treatment by model regulations are, for example, waste and wiper rags, and pork loins, which are frequently sold gross weight for net as a trade custom, thus causing the weights and measures official to receive complaints which are difficult to handle because of the variance of interpretation in the various jurisdictions.

I have enumerated just a few instances where model regulations would furnish a valuable guide to the weights and measures officials in the various jurisdictions. There could be many more such items which might require special treatment. The Conference Committee on Methods of Sale has since its inception presented many items around which regulations might be drawn.

It would be advantageous to all weights and measures officials, and especially so to those in States with newly created weights and measures departments, if the National Conference were to draft model regulations which could be incorporated in the regulations established by those States. Model regulations would be a valuable supplement to the National Conference model law on the subject of weights and measures.

For the foregoing reasons, the National Conference could very well consider the necessity and possibility of creating a Conference Committee to draft model regulations. Such a Conference Committee on Model Regulations could effectively act as a clearing house, acting for the whole body, in recommending regulations as necessity might arise. Further, the committee could consider existing effective State regulations and then recommend for adoption by the Conference as model regulations those which are of national interest and import. If the Conference Model Regulations were then promulgated by the various State jurisdictions, whenever it was feasible, such action would give real effect and meaning to the ideal of "Uniformity of Interpretation and Enforcement."

In the same vein, we would be well on the way toward pure uniformity of interpretation and enforcement if all of the State jurisdictions, wherever and whenever possible and feasible so to do, would promptly promulgate and effect the specifications and tolerances for 
devices and the recommendations of methods of sale of commodities which this Conference body has adopted in the past and does adopt at each of its sessions.

Such uniformity of interpretation and enforcement would be of patent and manifold benefit to consumer, weights and measures official, businessman, and industrialist alike.

Most of the weights-and-measures officials with whom I have corresponded relative to this matter expressed the opinion that it would be well if the Conference were to give thought and consideration to the possibility of having the Conference adopt model regulations. Some weights-and-measures jurisdictions keep at a minimum the number of regulations promulgated under authority of their weights-andmeasures laws; the officials in charge of these departments feel that even though regulations have the force and effect of law, it is better to have the major principles concerning weights and measures written into the law itself, in this manner keeping abreast of the times. It is obvious that such procedure approaches perfection in weightsand-measures administration. However, even in such jurisdictions model regulations could well be used as a guide for proposed weightsand-measures legislation.

Several weights-and-measures officials, in expressing their viewpoints, stated that the preparation and drafting of Conference model regulations should be handled by a special committee; others expressed the opinion that it would be appropriate for the Conference Committee on Legislation to handle the matter because of the inter-related complexion of the activities of that Committee and the subject here under discussion.

As a result of this program assignment, your speaker has given the matter considerable thought. I would like to point out to the members that within the framework of this National Conference on Weights and Measures, serving that body with a zeal and a sense of responsibility rarely equaled in any other organization, there are two superlatively effective committees, namely, the Committee on Specifications and Tolerances and the Committee on Methods of Sale of Commodities. Personally, I feel that because of the community of interest of these two standing committees and because of their outstanding performance, in the event the Conference decides to create a special committee on model regulations, the Conference should avail itself of the experience and judgment of some of the members of these committees. Their participation in the drafting of model regulations would seem to be almost mandatory.

However, as you know, Dr. Condon, our President, has established a policy which prohibits Conference members from serving on two committees at the same time. Possibly Dr. Condon and the Conference could provide for the participation of certain members of the committees mentioned by having the chairman or some designated member of each of these two committees serve as ex-officio members of the special committee on model regulations. The Chairman or some designated member of the Conference Committee on Legislation could also very appropriately be an ex-officio member of the special committee. To this nucleus should be added the very important exofficio membership of Mr. R. W. Smith, the Conference Secretary. To provide wide participation and viewpoint, the President could appoint 
as many additional members as the Conference and the President might deem necessary to round out the membership of a special committee on model regulations.

These thoughts and recommendations are respectfully presented to you for your consideration, as another approach by concerted Conference action toward effective and meaningful "Uniformity of Interpretation and Enforcement".

\section{RECONSIDERATION OF ACTION RELATIVE TO THE NUMBER OF VICE PRESIDENTS AND ELECTED COMIITTEEMEN ${ }^{5}$}

Mr. Mundy. I move that the Conference reconsider its action taken on Tuesday relative to the number of vice presidents and elected executive committeemen for the National Conference on Weights and Measures. A number of the delegates to this Conference seem to feel that this matter was not sufficiently discussed on Tuesday, and I believe that an opportunity should be afforded for further discussion. Having originally voted in the affirmative on this question, I now move its reconsideration.

(The motion was seconded, the question was taken, and the motion was agreed to.)

Mr. MUNdy. I now move that the number of vice presidents and the number of elected executive committeemen for the Conference remain as they are at present, that is, that there be 6 vice presidents, and that the executive committee consist of the officers, ex officio, and 15 elected executive committeemen, and that this be the standard policy for the National Conference until such time as the Conference sees fit to change the policy.

(The motion was seconded.)

Mr. CRAwFord. It is felt that representation from the several sections of the United States will be better accomplished if no change is made in the number of vice presidents and elected executive committeemen. There is no reason for limiting the number as there is in the case of membership on standing committees.

Mr. G. W. WARNER. I may not be familiar with present procedure, but I believe there is no provision that the vice presidents be selected from certain sections of the country. I would like to have some provision made for the country to be divided into six districts so as to be sure that each section of the country is represented, rather than to have all six vice presidents nominated, possibly, from one section of the country.

The Secretary. I believe the Nominating Committee always gives careful consideration to the geographical distribution of the nominees which it presents to the Conference. It hardly seems necessary for the Conference to divide the country into fixed districts, and I believe that we can trust to the discretion of our Nominating Committee to give due consideration to that factor.

Mr. Mundr. I support the position expressed by Mr. Smith and have full confidence in the Nominating Committee to do justice to the different sections of our country.

(The question was taken, and the motion was agreed to.)

\footnotetext{
${ }^{5}$ For report on original consideration see pages 4-6.
} 


\section{IMPACT ON THE STEEL BUSINESS OF FORMAL SPECIFICATIONS FOR WEIGHING MACHINERY}

\section{By H. M. Roeser, Supervisor of Scales, Inland Steel Co.}

Since preparing my paper I have learned that your Committee on Specifications and Tolerances has given wise and careful consideration to what may appear to be the principal source of my discontent. However, here I am, all wound up with my Sunday punch cocked, and I don't know what to do with it except to turn it loose.

On this platform my purpose is to add constructiveness to the efforts of your Secretary, and your Committee on Specifications and Tolerances, in the revision of specifications for weighing and measuring equipment and the subsequent streamlining of Bureau of Standards Handbook H29. I am here with a background of responsibility for the operating maintenance of a population of 300 scales at one of our more enterprising steel-producing establishments, and the results of an attempt to evaluate the projected specifications in terms of that experience. As your intentions are pointed principally at the socalled "commercial" type of equipment, the mutuality of interest is not remarkable, to be sure; nevertheless, our motives in manipulating the force of gravity are identical, and our several means of doing it are sufficiently parallel as to justify claim to your attention. The treatment touches different phases of the specifications, and the present and anticipated effects upon us of their standing as authority.

The first phase treats with what seems to be a tendency to move in on "non-commercial" equipment. Whether or not that is intentional, and the compatibility of the maneuver, assuming it to be real, are not matters for me to question. From where I stand, the effects are as if the movement were, in fact, real; and hardship is a certain consequence. I shall get at the point by coming at it from behind.

Refer to Draft of Proposen. Specifications, Tolerances, and Regulations, General, issue of January 20, 1949, and to this paragraph:

A.2. Non-Commercial Equipment.-When the enforcing office examines noncommercial weighing and measuring equipment, that is, equipment which is used exclusively for the control of operations such as prepackaging, batching, inventory, accounting, and the like, these specifications and tolerances may, in the discretion of the enforcing officer, he applied to whatever extent is appropriate, due consicleration being given to the design and the conditions of use of the equipinent.

In that paragraph, danger is perceived. Reference to hardship already endured as the result of the principle being taken for granted may be omitted. The purpose here is to seek relief aby undertaking the elimination of future possibilities. The principal fault is that responsibility for judgment is placed in the wrong mind, namely, that of the enforcing officer. In general, the experience of such men is, or may be, adequately broad with commercial equipment; nevertheless, by the nature of that same experience, their habits of thonght are not conditioned to the needs of non-commercial equipment, and its divers requirements for capability within adequately economical limits.

I have found no amendment of the paragraph which suits my literary and technical tastes, and this limitation, therefore, forces the suggestion of substituting the one now to be read:

A.2. Non-Commerdial Equipment.-These specifications, tolerances, and regulations do not apply to non-commercial equipment, that is, all weights and 
measures and weighing and measuring devices not within the scope of paragraph A.1. Commerchal GQumment. When necessaly, or expedient for an official to judge or evaluate non-commercial equipment, the utility generally will be in those terms applicable to new commercial equipment; and, more particularly, before the noln-commercial equipment is assembled with collatelal facilities in the production disturbances to the same extent expected of commercial equipment. Circumstances of space, vibration, temperature, material handling, coordination of machinery, and the like make the needs of commercial equipment for refinement in the arrangement and spacing of graduations, and the form of indicators, as well as nicety of performance, economically intolerable for most non-commercial equipment.

With the paragraph just read, an official has a confident basis of operation when, as commouly happens, he is called upon to evaluate non-commercial equipment procured, or operated, by public agencius within his jurisdiction; a function properly expected of him. It does not require improbable physical capacity and powers of judgment when and for whatever reason he is called upon to act with respect to non-commercial equipment procured, or operated by private agencies. Regarding the functions of machinery upon whose economical performance the survival of a business depends, when the judgment of an outsider supervenes that of management responsible for: the survival, strife is inevitable. The paragraph to which exception is taken seems to offer gratuitously possibilities for controversy disproportionate to the cause, or beneficial effect, which may be anticipated of it.

Although not in the sequence of the text, the note just struck properly precedes consideration of the previous paragraph on commercial equipment; first, because of the collateral involution in any consideraltion at all of it; and second, because this paragraph probably stems from circumstances never involved in the original conception of paragraph A.1. The latter assumption seems reasonable on the grounds that until quite recent times the stimulating circumstances did not exist.

'To the point, I shall read first from the issue of January 20, 1949, the paragraph:

A.1. Commercial Equipanent.-These specifications, tolerances, and regulations apply to commercial weighing and measuring equipnent, that is to weights and measures and weighing and measuring devices commercially used or employed in establishing or checking the size, quantits, extent, area, or measurement of quantities of things, produce, or articles for distribution or consumption, purchased, offered, or submitted for sale, hire, or awald, or in computing any charge for service rendered on the basis of weight or measure, or in determining weight or measure when a charge is made for such determination.

The part which interests me is that which relates to charges for services rendered. As previously indicated, I am sure the reasons for my being interested did not exist prior to conception of the general idea, nor was it involved in the basis of the law and regulations heretofore given you to enforce. My concern is whether those factors are intended to be blanketed by the language quoted. In any event, it is sought to have the facts clearly established, and in order the issue may be unequivocally drawn, following is a suggested revision of the paragraph :

A.1. Commercial Equipment.-These specifications, tolerances, and regulations apply to comnercial weighing and measuring equipment, that is, to weights and measures and weighing and measuring devices used in establishing: or checking the size, quantity, extent, area, or measurement of quantities of 
things, produce, or articles for distribution or consumption, purchased, offered, or submitted for sale, hire, or award, or in determining weight or measure when a charge is made for such determination, or in eomputing any eharge for serviee rendered on the basis of weight or measure: Provided, however, That any produetion incentive based on weight or measure whieh supplements a wage rate per hour, day, or other unit of time shall not be eonstrued as a eharge for service.

To that properly may be added an explanatory footnote; namely,

Basieally, prodretion incentives are established by non-eommereial equipment in cirenmstances where the kind and performanee of weighing or measuring deviees is eompatible with the over-all eeonomy of produetion proeesses from which the ineentives derive.

Having laid the background in so circuitous a fashion, the impact upon the steel business of the subject matter in the two paragraphs for which revision is suggested may be exhibited.

In industries such as ours, where huge quantities of raw materials are compounded and processed into finished goods, or articles of commerce for subsequent processing, management-labor relations in recent years have taken on a face, new, at least, to these regulations. The feature involved here is that the quite general practice is to bargain for labor for moderately long periods during which the wage per hour, or other unit of time, is established for each class of job included in the negotiations. That is to say, except to the extent clocks and calendars are measuring devices, the subject matter questioned has no force, because, basically, the charges for services rendered are established by rate factors in money multiplied by elapsed time required for the service.

The practice is quite as general, however, and labor contracts countenance it, to establish supplementary compensation called the "production incentive." In any manufacturing operation, the parties to a labor contract may supplement it with an agreement that a given amount, or kind, or number of units produced shall represent normal expenditure of effort, and that supplementary compensation shall be paid for production in excess of the norm. This is the production incentive. Universally, it is established by a rate factor in money multiplied by quantity of goods measured in the units the goods are commonly handled in commerce. By force of circumstances, the measurement is with the same facilities used in the manufacturing processes from which the goods derive; that is, non-commercial devices.

I want to be understood now. These goods are not measured in the production processes, and again measured for the purpose of establishing the production incentive. The production incentive derives from the measurement involved in the manufacturing operations.

The scope is broad. It may be taken for granted that the production incentive based on weight or measure is involved at some time, probably more than once in every article of commerce now produced by organized labor. In the steel business, and others of a similarly basic nature, the production incentive is on a tonnage basis; and, in the vernacular of those who jealously, if not zealously, sweat for it, is known as the "tonnage bonus."

Industrial processes require weighing and measuring facilities for the purpose of quantity, quality, and production control; and buildings, real estate, machinery, and production lines were laid out before the production incentive as now established became a universal factor 
in the production of goods. The weighing and measuring facilities may not, and in many, if not the majority of instances, cannot meet the generally established "commercial" weighing and measuring device standards. The weighing and measuring functions essential to the production incentive became superimposed upon the existing instrumentalities simply because they happened to be there.

This phase may be closed with the direct question, "Is it your intent that weighing and measuring equipment, basically non-commercial in character and functions, be transformed to commercial equipment by the incidental fact that production incentives are superimposed on production processes in which the equipment is involved?" In other words, within the meaning of the projected regulations, do you regard the production incentive as a charge for service?

Should the reply be affirmative, we cannot comply to an extent worth the attempt to do so; and, otherwise, the impact upon industry is such that recourse, both effective and rapid, must be found. If negative, the revision just suggested makes the fact clear and understandable.

A second phase deals with substance of the specifications. Generally, the detrimental effect upon industry derives from a self-created atmosphere of all-purpose sufficiency which surrounds them. The vendors of weighing machinery back up against the specifications and send their catalog carriers into industry with equipment which in the production lines perfor'ms like notion-counter hardware. The evil consequences are laid to ill usage, and carelessness and ignorance in operation. The simple fact is the equipment never was good enough. The ignorance, or carelessness, if not actually cupidity, is in reliance upon the inference left by the specifications that the equipment must be good enough.

With respect to the public interest within your province, your intentions cannot be vitiated by circumscribing the specifications with language which italicizes the extent of application. For instance, consider General Scale Specifications, issue of Febluary 4, 1949, page 3, paragraph S.1.1. :

GenERAL.-A scale shall be of such materials and construction that (a) it will support a load of its full nominal capacity without developing undue stresses or deflections, (b) it may reasonably be expected to withstand normal usage without undue impairment of accuracy or the correct functioning of parts, and (c) it will be reasonably permanent in adjustment.

In a non-commercial scale, especially in the steel business, the nominal capacity has little association with the amount of load a scale must carry without developing undue stresses or deflections; and in clause (b) the "normal usage" with which sustained accuracy and correct functioning of parts is associated is, I am sure, something quite different from what the man who wrote this specification had in mind. Prefacing clause (a) with the words "Except for non-commercial equipinent," and elimination of clause (b) would, in every instance, necessitate an agreement of mind between buyers and sellers as to load-sustaining capacity and what comprises normal usage; and, therefore, different methods of merchandising weighing equipment, especially to industry, must follow. As any different method offers improvement, one with faith that justice will sometime triumph can 
hope you will see through to the suggested amendment. To the end of speeding the act, literary criticism is offered that either clause (b) or clause (c) supererogates the other. One can be left unsaid. Please drop clause $(\mathrm{b})$.

In the same vein, the code might be considered paragraph by paragraph. 'That, however, is too exacting an undertaking to be considered liere, especially so, if, as may be fairly assumed, the remarks thus far do not leave you wholly in sympathy with what is being suggested. I shall bypass it, therefore, after some comments on odds and ends of which the next is the requirement that pivots and bearings be made of hardened steel in paragraph S.1.4, and S.1.5.

Hard material, per se, is not necessary for pivots and bearings. If steel is the material, experience has shown it must be hard. The essential reason is not in the hardness itself, but in that, with steel pieces, deformation at the points or lines of contact is reduced as the result of adequate heat treatment of the metal. To insure security in the results, specifying the steel analysis and the degree of hardness is necessary. Other materials suitable for pivots and bearings are less exacting in the necessity for hardness control, a fact promotional to remarkable economies in manufacture, and maintenance. Thus, it happens that this venerable specification, which was a stand-out in that stage of civilization when industry was converting from flint and obsidian to the use of metals, is now viewed with some irreverence, if not actually one to be honored by breach rather than observance. You could with good grace take cognizance of the development.

Paragraph S.1.10. Unit-Weight Mechanism apparently considers only manually operated nnit-weight systems practicable. As it stands, the paragraph will tend to deter, or scare off, developinent of automatically operated unit-meight systems which could do well in the steel business.

A third phase is brief, and deals with substance the specifications presently do not have. All agree that provision for maintenance is essential to the quality of performance the public interest requires. Only moderately do the specifications touch this phase. You need to be detailed on the facilities for access, cleanliness, and amount of space for safe and adequate attention to inspection and repairs. It is sad testimony on business practice that vendors in their competitive tactics present to potential customers designs which show such facilities at a minimum. Inevitably in practical construction, the minimum requirements become shaded. You could properly improve matters by becoming specific on the requirements for accessory facilities below which outright condemnation will result.

Another aspect of the phase is the absence of requirements which insure adequate identification and fit of replacement parts. Presently, in the scale business indifference to the needs is a handicap to satisfactory maintenance-indeed, if a prevailing contention is true that the state of average maintenance is unusually low, the statement just made will serve as an explanation to which the contrary will be difficult to prove.

Parenthetically may be said that in the steel business maintenance is as essential as survival; and, perforce, we have it licked insofar as that can be accomplished within our own resources. To the same extent as 
any one else, however, we are liandicapped in identifying parts without the services of a major prophet, and making parts fit which camot. Help, please!

The specifications, of course, point up to requirements for performance; that is, tolerances, or allowable variation between indicated weight and applied load. Your interests are different from ours. The two may even be regarded as mutually exclusive; nevertheless, in this final phase of the subject, it seems well to highlight the irreconcilable differences to the end that common ground, if any, may be discovered. To the extent these figures called "tolerances on scales" neither recognize the waste in requiring a reighing machine to be better than the economic circumstances of use require of it, nor that nobody has little enough sense to put up with anything worse, many men who get things done regard them as lacking practical insight. Such men are stubborn, indeed, on the point that a tolerance good enough for an old scale is good enough for a new or rebuilt one in the same circumstances of use.

If a distinction is to be made, one regarding automatics may be justified. Automatics do better after a period of use, or shaking down. 'The tolerance on new automatics, therefore, sensibly could be greater than for old. That heretical utterance is not for a laugh; but rather for serious consideration. The steel business needs automatics. This tolerance schedule is one of the reasons they are not available. Because of it, inventors and manufacturers are constrained to primitive considerations which do not now, and cannot ever meet the over-all needs of the steel business.

As a background into which ideas may take root, presenting the details to which you have listened patiently appeared advisable. The effort, however, might have been limited to the following summation of it. First, in general, to us in what you call the "non-commercial" field is apparent you do not realize the disadvantages which result from influence of the specifications beyond your intentions. To the extent it can be done without prejudice to your intentions and policy, we are privileged to assume you would be interested in suitable measures pleventive of such disadvantages. We ask that you consider doing just that. Secoud, in particular, we ask for a sharper line of distinction between commercial and noncommercial equipment; and more particularly, a shar'p construction of that language "computing any charge for services rendered on the basis of weight or measure." The issue may be left in the form of a simple, homely question.

Consider an apple grower for the cider market, and that he hires apple knockers at a dollar a day. In this instance the language is not applicable. Should he hire knockers either for a dollar a day, or 10 cents a bushel if more than 10 bushels are knocked, the language is applicable. If, however, he hires knockers for a dollar a day plus a bonus of one cent a gallon on the daily cider production, a wage scale basically on a rate per unit of time with a production incentive both for quantity and quality of apples knocked, do you intend the language to require measurement of the cider gallon by gallon on a "commercial" basis when the production routine is to eatch it in crocks and stash it away for the hardening operation? 
In the implications of the question are potentialities for grave disturbances in relations between labor and management, as well as economy of goods to the consuming public. It's a clutch, no less.

As I have mentioned previously your people have given wise and sound consideration to the principal source of this expression of discontent, and for my people and myself I want to thank you and them very much for that kindness.

The Chatrian. Item No. 24 on our program is scheduled as "Exchange of Information Among Weights and Measures Jurisdictions." Mr. F. J. Heironimus, Assistant Chief of the Division of Weights and Measures of the State of Texas, was unable to attend the Conference and because he has not submitted his paper I am canceling Item No. 24.

(At this point, at 12:45 p. m., the Conference recessed for luncheon.) 


\section{FIFTH SESSION-AFTERNOON OF THURSDAY, MAY 26, 1949}

(The Conference reassembled at 2:10 p. m., Robert Williams, Vice President of the Conference, presiding.)

\section{SYSTEMATIZED PACKAGE SUPERVISION}

By I. M. Levy, Sealer of Weights and Measures, City of Chicago, Itl.

In years past practically all commodities were sold in bulk. That method has been gradually changing and now most items purchased by the public are preweighed or premeasured. Up to 3 years ago, the City of Chicago had no ordinance pertaining to commodities in package form. When complaints were received by this office and when flagrant violations were found, we prosecuted under the State law, calling into court a prosecutor from the State's Attorney's office.

As the prepacking of commodities increased, complaints became more numerous. We then introduced an ordinance in the City Council, an exact duplicate of the State law, and this ordinance was passed on our recommendation that it was urgently needed to protect the public against unfair and dishonest treatment. To enforce this ordinance, we assigned an inspector to make a survey at the source of commodities sold or offered for sale in package form. In making these initial inspections, we found that we did not possess the proper standards. After many months of visiting laboratories and getting information, we acquired a complete set of standards, suitable for testing the contents of any commodity in package form, sold by weight or liquid measure.

Equipped with these standards, we made inspections which, being new to the various industries, were resented in the beginning, but after calling their attention to the ordinance under which we received our power, they reluctantly conceded, and as time went on they were quite surprised at the number of violations which were pointed out to them and which they eventually corrected. Getting the manufacturers and processors to cooperate with us, however, was an uphill battle, and we received their full cooperation only after several successful prosecutions in court. Today they not only welcome us but call on us for advice on their packaging problems. As a result, over 50,000 packages have been checked in the past 2 years. We now feel we are being rewarded for the hea daches suffered in bringing about this cooperation and in the knowledge that the public is receiving the full weight or measure for which it pays.

We would like to call your attention to two of the most flagrant violations encountered and ask the help of this Conference in correcting them. The first problem is the canning of whole chickens. The can is labeled "Whole Chicken 3 lbs. net contents," and in small print at the bottom of the label: "Bouillon and salt added." In 
checking the canning of these chickens at the plant in Chicago (incidentally these cans are shipped to all parts of the country) our inspector weighed 12 dressed chickens from a conveyor belt to be put in cans, and these chickens weighed from $1 \frac{1}{2}$ pounds to $21 / 2$ pounds net. A fter the chickens were packed in cans, they were then placed on another conveyor and sent to a table where an employee had an evenbalance scale and, with an empty can as tare, she filled the can with a liquid which brought the weight to 3 pounds, including chicken and broth. 'This liquid was piped from the floor above and, as far as we could ascertain, was not derived from the chicken. The can was then conveyed to a retort and contents cooked. We instituted court proceedings against this firm and the court upheld them, in that the contents of the can weighed 3 pounds net. The judge in explaining his ruling stated that, in his mind, it was an unfair way to treat the public, but that there was nothing in our ordinance to prohibit a packer from packing a 1-pound chicken and 2 pounds of liquid, labeling it as 3 pounds with bouillon and salt, and he advised us to have an ordinance introduced compelling these companies to pack 3 pounds of chicken when labeled "3 pounds."

Another problem which we believe to be a national one is the selling of paint in cans labeled "1 gallon." Our survey has shown that 95 percent of the gallon cans of paint which we checked average 3 fluid ounces short of the required 128 fluid ounces. The explanation given by the various paint manufacturers was that if they filled their cans to the required 128-fluid-ounce mark the lid of the can would blow off; the cause of this would be the insufficient head space and expansion of the contents due to rising temperatures. After a few successful prosecutions and several conferences with the officials of the largest paint manufacturels and can companies we succeeded in partially cutting this shortage. However, we are handicapped in wholly correcting this violation, as the paint manufacturers at our last conference in February complained of our being the only city enforcing the filling of paint cans, although New York and Cleveland surpass us in the manufacture of paint, and, therefore, they feel that they, as Chicago manufacturers and taxpayer's, are being discriminated against.

In our survey of the various items in package form we have observed that most violations occur in the wording of labels-liquids labeled "16 ozs. avoirdupois" instead of "1 pint" or "16 fluid ozs.", solids sold as "Net Weight" instead of "Net Weight Avoildupois", and semi-solids or liquids not definitely labeled as either "avoirdupois" or "fluid" ounces. We hope to see laws adopted in all States to make it easier for all manufacturers to comply and to assist weights-and-measures officials in the process of inspection.

The cracker barrel of yesteryears and the old-fashioned icehouse have given away to modern packaging and the deep-freeze units of today, and we, in weights and measures, must keep apace with the times. Frozen foods in particular pose many problems; without putting stumbling blocks in the path of progressive marketing methods we must nonetheless remain alert to the interests of the consumer. Frozen foods are reighed and labeled in the plants of the processors often hundreds of miles away from the point of consumer purchase and out of the jurisdiction of the local weights-and-measures officials. 
It is my belief, therefore, that we have no other choice but to hold the retailer accountable for accurate weights of frozen foods, as we do of fresh foods. This may impose some hardships, but I am sure that the processor in his desire to keep in the good graces of those who sell his products, will make every effort to shoulder this responsibility.

Frozen foods ofttimes, perhaps most of the time, arrive at the retail establishment with the weights correctly marked, but if they are placed in frozen display cases which are left open most of the day, a certain amount of evaporation is bound to take place with a resultant loss of weight. Under such circumstances, it seems to be incumbent on the processor to overpack to an extent which will allow for this evaporation and thus assure the consumer of full weight at the time of purchase. We have noted that fast-moving merchandise has much less tendency to become defrosted and lose weight than packaged commodities which remain in the frozen display cases for a greater length of time.

We all have the same problems-insnfficient appropriation and manpower to make the number of investigations necessary in all places of business where commodities are prepackaged. In Chicago, due to a shortage of inspectors, we can assign only one man to do this work. We know you all realize the amount of prepackaging done in Chicago, and we take this opportunity to ask all here present to communicate to us any violations you may find, thereby enabling us to correct these discrepancies at their source.

A step in the right direction towards the solution of this problem would be the formation of a central clearing committee which would serve as a channel through which information between city and State departments of weights and measures officials could flow. A working agreement could be determined upon whereby officials in cities where frozen packaged items are sold could refer matters to officials in locations where the product was packed. In such areas the weights and measures officials would keep a very close check upon the packer or processor. From my experience, there is a fine spirit of cooperation among officials of weights and measures, but I believe in this particular instance it should result in an organized and systematic effort on our parts.

\section{FEDERAL AID IN WEIGHTS AND MEASURES PROGRAMS}

REMARKS OF J. H. MEEK, DIRECTOR, DIVISION OF MARKETS, STATE OF VIRGINIA

After the program had been made up I suggested to Mr. Smith that the subject I then had might be changed to "Coordinated FederalState Activities for Improving Weights and Measures Services." However, the discussion would have been the same.

The preceding speaker has brought out very pointedly the need for some of the things that I am going to outline. Some of the ways and means of securing those objectives I consider adequate, while I would not consider adequate his suggestions for others. Many different committees would be involved and many of those committees would not be effective or far-reaching enough to meet the needs of the people of the country.

The motto for the work that I have been responsible for since 1920 has been, "The greatest service to the greatest number at the least cost," and the slogan, "Make the best buy"; it is in that spirit that I say what 
I have to say here today. I hope that my remarks will be received in that spirit.

Any activities or services must have dependable financial support if they are to get the necessary lesults and adequately meet the needs. From my 20 year's experience in an administrative capacity dealing with weights and measures services, I am convinced that these services throughout the country as a whole have never been properly financed. However, there have been some gains in the past 20 years, but they are too often too late, or too late too often.

Without making a detailed survey, I believe that my own StateVirginia-has moved from the lower-financed group to the higherfinanced group, but it has taken too long and we still have too little. General information indicates that some States yet have very few weights and measures services, while othel's are totally inadequate and few are properly financed. I am one of those who believes that the States should do their part and that centralization of services in the Federal Govermment has gone too far in some activities, yet approximately 20 years ago I appealed to those attending this Conference for closer coordination of Federal and State activities for uniformity and efficiency without unreasonable centralization, but with uniform interpretation of regulations and practical application in the field.

The school on the calibration of standards of length, mass, and capacity now being conducted by the U. S. Bureau of Standards is helpful in that direction. However, we need more men connected with the U. S. Bureau of Standards especially trained in working out and carrying out specifications, regulations, tolerances, etc. We must have more of these services if weights and measures needs are to be properly met. I suggest that men in the State and local jurisdictions call on officials of the U. S. Bureau of Standards for these services.

I would like to point out, however, that the Bureau of Standards has for a number of years harped on the fact that weights and measures was not given the proper lecognition in the States and localities. It is their recommendation that weights and measures should have at least division status in the States, if not department status. I make the point that the same condition exists in the Federal Government as in the State and local governments.

The activities of the Bureau of Standards toward uniformity in weights and measures laws and their enforcement throughout the year's has been immensely constructive, but what we really need is more of it. If weights and measures is as essential to the welfare of commerce, industry, and agriculture, and the consuming public as weights and measures officials have been led to believe, it would certainly appear that the Office of Weights and Mensures should have a staff of at least ten specialists who would be available to the States to assist in training their personnel and in working out the multitudinous problems with which the State officials are confronted daily. Investigations could be made on various matters which have long been neglected. I am sule that Ralph Smith could think of hundreds of necessary things for such a staff of men to do.

Consider the plight of a newly appointed State official who, as you know, is often a political appointee and comes into the work without any previous experience along these lines. How much easier it would 
be for him and how much better for the citizens of his State if he could have an experienced and capable weights and measures specialist flom the Bureau of Standards spend several weeks, or as much time as may be necessary, in indoctrinating him in the duties of his position.

Another function in the weights and measures field which it has always appeared to me should certainly be performed by the Bureau of Standards, is the matter of type approval on weighing and measuring devices. If this were performed at the National Bureau of Standards, type approval on these devices would really mean something. Exhaustive tests could be performed to prove whether or not the devices would maintain their accuracy over a period of time. These tests would be performed by people with technical training, and from the standpoint of the manufacturer should certainly be more satisfactory than the present set-up, where some 10 jurisdictions in the country require type approval, and many others make no attempt along these lines.

$I$ do not know how much a program such as $I$ have outlined would cost the Federal Government, but I would think that with $\$ 150,000$ to $\$ 200,000$, which is a mere pittance in the Federal budget, a great deal of constructive work could be done which would tend to improve the entire weights and measures program throughout the United States.

In addition to the foregoing suggestions for broadening of the Federal field in weights and measures, if the Office of Weights and Measures were properly staffed, more extensive research could be made on the methods of sales of commodities in cooperation with other Federal agencies, and an extensive study on needed weights and measures legislation could be made and assistance given the States in getting such legislation enacted. Courses could be held periodically at the Bureau of Standards on the testing and inspection of commercial weighing and measuring devices, which could be attended by both State and local officials. The possibilities for constructive work by an expanded Office of Weights and Measures in the Bureau of Standards seem countless. If weights and measures at the lower level ever receives the attention which it undoubtedly deserves, the example should certainly be set at the top level of government.

Furthermore, we are facing the fact that in 1932, approximately three-fourths of the tax dollar went to local and State governments, and one-fourth to the Federal Government; while in 1947 this practically reversed itself-one-fourth of the tax dollar went to local and State governments, and three-fourths went to the Federal Government.

We are facing a more serious possibility; that is, with sucl a little being done on weights and measures in so much of this country, the Federal Government in case of war might take over all weights and measures activities. I know some men engaged in weights and measures work do not agree with me in this matter, but there is one thing that we do agree on, and that is that the Federal Govermment should not take over full control of these services; yet, there are many Federal activities now and others proposed that are more far-reaching than this would be. What we need for proper services, and what we $858144-50-9$ 
need to guarantee the prevention of the Federal Government taking over weights and measures services entirely, is coordinated teamwork among all weights and measures people from the Federal, State, city, and county, or other local governments.

The major portion of my responsibilities deals with the marketing of foods and farm products from producers to consumers. I am confident that we have in that field better coordinated relations with the Federal agencies than any other State in the Union. I know that we have several services that no other State has. I will give you one illustration.

For 12 or 15 years I have been working toward a coordinated service on processed foods. The Federal Government has had an official service; the States have had none. We got that service started last July, and Virginia is the only State that has it. We thought that the Federal man in charge would use about half of his time in the actual official inspection of these commodities and about half of his time in coordinating activities. We find that the demand has been so great that not only has this man been more than busy but several other employees also have been rushed. The voluntary fees coming in are sufficient to finance the program with the exception of the laboratory equipment; we had thought we would only get fees enough to finance about 25 percent of the program.

This service is reaching large proportions all at once. In 1 year's time it has checked 50 million pounds of numerous commodities. For example, we may get a call to inspect eight cars of frozen food within a couple of days, which will go out from Virginia points to the four corners of the world. Then there are those products coming in from numerous States, particularly California and Michigan. But they may come from any other State.

The possibility of determining not only the quantity, which is only one factor in protecting the consumer, but the quality of these commodities all the way from the producer to the consumer is an important factor. The field is unlimited. No one agency is going to do the job; it takes the forces of the local, the State, and the Federal agencies. We are only scratching the surface. We must learn to work together or, as the unfortunate trend to socialistic government or communistic government grows, the program will be taken over by the powers that be.

If it is my privilege to meet with you again in the years to come, I hope that $I$ shall see a greater growth in meeting the actual needs of consumers than I have seen in these past 22 years; under the circumstances, much has been done-but not enough. We should not be satisfied. We should "Make the best buy."

\section{REMARKS OF DR. E. C. CRITTENDEN, ASSOCIATE DIRECTOR, NATIONAL BUREAU OF STANDARDS}

The subject listed for discussion at this time is the general one of Federal Aid in Weights and Measures Programs. Some aspects of it have been brought out by Mr. Meek. I could probably stir up more argument if there were more points on which I differ from his views. We certainly can agree with him that promotion of the proper use of weights and measures is an appropriate governmental activity, that it deserves better support than it now receives, and that it can be handled 
most efficiently by cooperation of Federal, State, and local governments.

With respect to the last point, the existence of this Conference, and its continued operation over a period of 44 years, give living evidence that in the field of weights and measures there has been cooperation between Federal, State, and local governments. We know also that the Conferences held and the committee work done have been useful in bringing abont some degree of coordination between the regulations and the practices of different jurisdictions.

Undoubtedly the Federal Government might do more in this field than it now does. The Constitution of the United States gives to the Federal Congress authority to "fix the Standard of Weights and Measures," but this authority has been very sparingly exercised. Under an Act of June 14, 1836, most of the States of the Union were supplied with sets of standards similar to those made for the Customs Service. This was done, as the Act says, "to the end that a uniform standard of weights and measures may be established throughout the United States." The Congress, however, did not say that the use of these standards would be obligatory in the States. In other words, the legal adoption of basic standards was left to the States, along with regulation of the practical applications of those standards.

While a few specific laws on commercial measurements, such as those defining containers for certain commodities, have been enacted, the policy of leaving jurisdiction over practical weights and measures to the States has been generally followed by the Congress. It has been assumed also that the responsibility for the work carries with it the requirement of financial support. Mr. Meek has emphasized the fact that taxes imposed by the Federal Government have been increased until they take three times as much money out of our pockets as do combined State and local taxes. We know, of course, that a very large part of this increase in Federal taxes is due to past wars and the fear of future ones. However, a large and growing part of the budget of the Federal Government is devoted to services carried on by the States with financial aid from the Federal Government. Federal contributions to the States and local governments for welfare work, highways, airports, and education averaged over $\$ 1,660,000,000$ during the last two fiscal years; they are expected to amount to $\$ 1,963,000,000$ this year; the estimate for next year is $\$ 2,480,000,000$. Compared to these astronomical figures the total amounts spent for weights and measures work are pitifully small. A contribution which might greatly increase and strengthen weights and measures inspection would be a mere mite in the immense Federal budget. However, it is an old principle that he who pays the piper calls the tune. Federal Government contribution of funds would imply more or less supervision or control of the work. I am inclined to think that really effective control of weights and measures is as much a problem of education as of police action, and that the development of popular understanding and support is essential for its success. If this is so, the job is one that State and local officials can do better than any one sent out from Washington.

Nevertheless, I believe we all agree that there are some parts of the work in which the intervention of a national agency is essential; and the National Bureau of Standards is the appropriate agency, 
although it las, and seeks, no authority to regulate anybody's operations. The law under which the Bureau was set up in 1941, and under which it still operates, specified that "the functions of the bureau shall consist in the custody of the standards; the comparison of the standards used in scientific investigations, engineering, manufactiring, commerce, and educational institutions with the standards adopted or recognized by the Government; the construction, when necessary, of standards, their multiples and subdivisions; the testing and calibration of standard measuring apparatus; the solution of problems which arise in connection with standards; the determination of physical constants and the properties of materials, when such data are of great importance to scientific or manufacturing interests and are not to be obtained of sufficient accuracy elsewhere."

It may be noted that no phrase in the basic law quoted gives the Bureau any regulatory powers. In fact, there is no specific provision even for cooperation in regulatory activities of State or local governments, but the Bureau has taken the view that its statutory authority should be interpreted broadly to permit nseful services unless they are definitely forbidden. So it has held that regulation of the use of weights and measures is one of the "problems which arise in connection with standards" and therefore is a field in which the Bureau is authorized to work. There is now pending a revision of the law intended to state the Bureau's functions more clearly and explicitly. In it there is included a clause authorizing "cooperation with the States in securing uniformity in weights and measures laws and methods of inspection."

In brief, the limits of legal power's as granted by Congressional action and the historical policies of the Congress and of the National Bureau of Standards itself give little reason to fear encroachment by this Bureau upon the field of work of State and local agencies. Within the limits of its resources the Bureau administration looks forward to further development of the happy relations which have existed between it and the other agencies which have cooperated so effectively in the National Conference. We must, however, bear in mind the hard, practical fact that our work costs money, tax money, which constitutes a part, although a very small part, of the burden to which Mr. Meek has referred. The Budget Bureau and the Congress do not lightly make even small increases in our funds. A section of the law now in effect provides "that the bureau shall exercise its functions for the Government of the United States; for any State or municipal government within the United States; or for any scientific society, educational institution, firm, corporation, or individual within the United States engaged in manufacturing or other pursuits requiring the use of standards or standard measuring instruments." This list makes the Bureau responsible for service to an extremely large number of interests. The growing importance of exact knowledge in all branches of commerce and industry, as well as in scientific research and development, and the growth of entirely new branches of science and of industry have broadened this field of responsibility almost too rapidly for the Bureau to keep up with it. It has been necessary, therefore, to spread our resources very thin, and to weigh the claims of each special field of service against those of many other possible activities. 
In view of these broad responsibilities of the Bureau and the need for strict economy in Federal Government expenditures, it would be too optimistic to forecast an expansion of the Bureau's activities in weights and measures so ample as $\mathrm{Mr}$. Meek has suggested. Nevertheless some progress in that direction has been made in recent years.

With regard to the position of weights and measures in the Bureau organization, the National Conference has always been recognized as an activity of such basic importance as to deserve the personal participation of the Director. For many years, however, the Bureau's work in weights and measures administration was one of many duties assigned to the Division called Weights and Measures. The establishment of the Office of Weights and Measures as a part of the Director's administrative staff, with the coincident renaming of the laboratory division as the Division of Metrology, was an explicit recognition of the distinctive character of this work as well as of its importance. Naturally the activities concerned with regulation cannot be divorced from the laboratory work on standards and methods of measurement, and there must be close correlation between laboratory and field work. For example, the courses on calibration of standards at the Bureau for State officials were given by the staff of the Metrology Division. However, the renewal of actual contact with your work in the field, which had been almost completely broken off during the war years, has naturally been the job of the Office of Weights and Measures. A great increase in this activity has been made possible by our good fortune in getting Mr. Bussey from Texas. We have just this week brought in a further reinforcement in the person of Mr. Robert J. Neale, who has come from the staff of the State of California. Eventually the Bureau hopes to be in a position to give more assistance in the field to netr State officials or to others who may desire such assistance as suggested by Mr. Meek. This may be more practical than to bring groups of State men here to Washington as has been done during the past 2 years. Obviously, such an expansion of our service to weights and measures organizations is contingent upon the appropriation by the Congress of the required funds.

Adequate State laws are, of course, essential as a basis for regulatory activities. The Bureau has well on the way a revised compilation of present State laws affecting weights and measures. Mr. Smith is always glad also to work with anyone in the States to promote the enactment of better laws, although the Bureau must, of course, avoid giving any ground for the feeling that it wants to dictate the action of State legislatures.

One aspect of this problem of legislation is the important question of approval of types of weighing and measuring devices. In most of the larger countries provision is made for such approvals on a national basis. Even in a country which is so large as ours and includes regions where conditions of trade are so diverse, national uniformity as to general requirements of construction and performance of devices would appear to give notable advantages, particularly if administration of approvals were flexible enough to give freedom for development of improved types. If adopted on a national basis, approval of types of weighing and measuring equipment would logically become a responsibility of the National Bureau of Standards. The Bureau, however, is not seeking such responsibility and authority; in fact, the 
exercise of any regulatory pỏwers would be a departure from its traditional policy.

Finally, I would like to emphasize the fact that suggestions regarding matters on which the Bureau can give assistance in your work are always welcome. We have more calls than we can meet, but demands and criticism from those we serve help the Bureau administration in determining where its resources can be used to the best advantage.

\section{REMARKS OF DR. LYMAN J. BRIGGS, FORMER PRESIDENT OF THE NATIONAL CONFERENCE ON WEIGHTS AND MEASURES}

The Chatrman. We are very happy to have with us this afternoon Dr. Lyman J. Briggs, a former Director of the National Bureau of Standards and a former President of this organization, and presently the Director Emeritus of the National Bureau of Standards. We should be glad to hear from Dr. Briggs at this time.

Dr. Briggs. This is a totally unexpected and unprepared-for pleasure. It is pleasant for me to be with you again and to learn what is now engaging your attention in this most important work. As I look back over the years, I realize that you have made important advances and that, as in all fields, there are still great opportunities. As Dr. Crittenden has pointed out, the relations between the Bureau and the various State organizations have always been pleasant and, in my opinion, they have been mutually constructive. I feel, personally, that we are now on pretty sound ground. The possibility of the Government going into the field of activities now being carried on by the State organizations seems to me to be rather remote. I do not see any reason for it. I hope to see the present relationships broadened and strengthened. Thank you most sincerely for calling upon me.

REPORT OF THE NATIONAL CONFERENCE COMMITTEE ON METHODS OF SALE OF COMMODITIES, PRESENTED BY J. G. ROGERS, CHAIRMAN, AND DISCUSSION THEREON

Preamble.-Your Committee on Methods of Sale of Commodities submits its report to the Conference. This Committee has already dealt so exhaustively with such a wide range of essential commodities in our trade structure, that the field yet to be covered is narrowing down to what may be considered as special items which, because of their nature, have created problems for solution at the official level. It is rather to be expected that in dealing with some issues there will be controversies when those affected do not see eye-to-eye with us in the decisions we reach. Sometimes the factor of custom has become so ingrained in an industrial or commercial enterprise that a change in methods, no matter how necessary to consumer protection, is not welcomed. The fact that our grandfathers pursued a certain course or method in business does not mean that their adopted procedures were always right or should be perpetuated. Some matters of custom, when viewed in their proper light, often assume a ridiculous aspect in this day and age, and among them are often found practices that are downright unethical or at least on the borderline of fraud and deception. Weights and measures officers as a class, we believe, are always disposed to be reasonable and fair in their treatment of topics that are controversial. Your Committee is of that group. Its approach to matters upon which attention is focused is through the 
avenues of fact finding and the byways of trial and error. We are conscious of the problems of industry and commerce. The ability of an industry to meet a mandate that might be imposed through a recommendation of this Committee, is well considered. We endeavor to work with an open mind always. There is no desire to exalt our differences with those we would regulate. Neither is there a disposition to create "bottlenecks" by nuisance requirements that produce nothing in benefits to consumer welfare. Friendly relationships among those at trade and official levels can and should be maintained by cooperative effort, with neither seeking an undue or unfair advantage. This is a policy that can well be entertained by all.

The following items received the consideration of this Committee since the last Conference:

1. Frozen Foods.-Item 1 in this Committee's report to the last Conference in relation to frozen foods was tentatively adopted. This had special reference to packages containing solids and liquids and was based upon the entire contents of such packages being consumable. The recommendation offered was that the amount of solids and the amount of liquids should both be declared in the quantity marking. This item is, therefore, open for final treatment. 'The thought behind tentative adoption was, we believe, to give the frozen food industry the opportunity to correct practices that appeared to be questionable in character, and it was felt that a year would be ample for the purpose.

It is not the present knowledge of the Committee that anything of a signal nature has been forthcoming to regulate the industry in certain of its methods relating to the issue we raised, nor that there have been any noticeable changes in processing and packing to correct questionable procedures. As nothing definite or better has been offered as an alternative for what we originally proposed, we are maintaining our stand on the merits of the recommendation first presented. We believe it to be a practical solution of a problem that has given the weightsand-measures-minded much concern. This recommendation is, therefore, now referred to the Conference body ior final adoption or rejection, according to the dictates of its judgment.

(It was moved by Mr. Blickley and seconded by Mr. Boyle that the recommendation relative to frozen foods, tentatively adopted by the Thirty-third National Conference, be finally adopted; the question was taken, and the motion was agreed to.)

2. Thread.-This topic was covered in item No. 4 of the Committee's report to the Conference in 1947. The simple terms of our recommendation at that time were that thread "Should be sold by linear measurement or by net weight, with an allowable tolerance not exceeding 3\%." The term "thread" was defined in the proposal, which also prescribed marking requirements and a provision that when the net weight of thread put up on any container is less than two avoirdupois ounces, the sale and quantity declaration by linear measurement should be mandatory. Woolen yarns were not included in the recommendation. The Committee's proposal was tentatively adopted by the Conference. The thread industry was substantially satisfied with all of its terms with the exception of the recommended tolerance of $3 \%$, to which it objected, as this represented a reduction in the prevailing tolerance of $5 \%$ incorporated in laws of the few States that have dealt with this subject. Representatives of the Thread Institute 
were of the opinion that the moot question of tolerance reduction should be given further study and consideration by the Committee and felt that the interim between Conferences would be ample for this. They also stated that on their part they would like to go further and draw up what they regard as a model thread law. The Thread Institute subsequent to the last Conference prepared and presented to the Committee a brief giving in comprehensive detail the listorical background of the industry in this country with references to the laws and regulations that have been adopted up to this time, together with a draft of a model law representing what they feel should be adopted to set up proper regulation of the industry from a quantitative standpoint. 'They later submitted a revised edition of their proposed model law in which they incorporated changes in tolerance requirements that nearly coordinated with this Committee's original recommendation. 'This was subsequent to a survey project undertaken by representatives of our group who visited a thread mill to do some fact finding. The industry now agrees with the $3 \%$ tolerance with the proviso that this shall be applied on the basis of test results from ten or more units and that a $5 \%$ tolerance be allowed for individual units. The industry is of the opinion that by providing a specific tolerance stipulation for the individual unit it would act as a deterrent to any manufacturer inclined toward short quantity practices. The Committee has no objection to treatment of the individual unit and its inclusion as a further means of breaking up questionable procedures at the factory level, but we do not favor this with a liberalized tolerance, as we are of the opinion that this would still be "leaving the door wide open" for dishonest producers to deliberately give short quantity to the limit of the tolerance, and it is because this has been done within the industry that the issue of tolerance reduction was first brought up. We believe that a $5 \%$ tolerance makes chance-taking attractive from the standpoint of profits, and undue advantage can and apparently has been taken of it because of the realization that many shortquantity units of thread will pass undetected, which, of course, creates a situation detrimental to the economy of buyers and users.

The proposed model law is well drawn and the Legislation Committee of the thread industry is to be commended upon the thought and effort they devoted to this. They also submitted to us with their first presentations in this connection, proposals for the adoption of the following three regulations:

1. Where the name of the manufacturer or distributor and his address do not appear on the individual unit of thread, the symbol, trademark, brand, or other mark of identification indicated on such unit shall be listed in the Register of Thread Brands and Trademarks maintained by the Thread Institute, Inc., the national trade association for the thread industry in the United States.

2. Not less than 10 units of any type of thread selected at random shall be tested before preferring a complaint against the manufacturer for short yardage

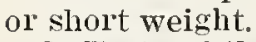

3. Tests of the weight or measure of any unit of thread shall be made in conformity with temperature and humidity conditions, and testing methods and procedures, established by the American Society for Testing Materials.

All of these presentations have been considered by the Committee and we submit our reactions:

We favor the latest draft of the proposed model law, with the exception of the 5 percent tolerance prescribed for individual units. 
We agree in principle with proposed regulation No. 1 relating to identification, as this should at all times be available. We could not go all the way with it, however, in any law adopted, as it stipulates an unofficial organization as the agency for the registration of trademarks and brands. Laws must be kept at the official level and the proposal should, therefore, be that such symbols or identifications should be registered with the authority having enforcement of the law.

We favor proposed regulation No. 2 from the standpoint of fairness to the industry in the official collection of samples for evidence. The industry has been fearful that weights and measures officers would prosecute on the evidence of a single unit. While this might happen in the absence of any specific provision against it, it would be contrary to good weights and measures enforcement practice, though it seems to be difficult to convince the industry of this.

We do not favor proposed regulation No. 3 as to testing methods at the official level. The procedure would be ponderous and difficult for weights and measures enforcement agencies who do not have the facilities at their disposal to make the tests as prescribed. Sufficient means are, however, available to the weights and measures officer to make adequate tests for the purpose of a law in which a prescribed tolerance would be the important controlling factor.

The outstanding issue in the thread situation is the controversial question of tolerance. It is with this that we would deal at further length. The Committee as indicated has fully considered all the arguments presented in the industry's brief and, in addition, a subcommittee comprised of three members of our group visited what is probably the largest thread factory in the world, that of $\mathbf{J}$. \& P. Coats at Pawtucket, Rhode Island. This was on the invitation of the Thread Institute. As the result of our observations there we are maintaining our stand on the recommendation for a 3 percent tolerance which, however, we now recommend be based on test determinations from not less than 10 units. WVe did not find anything in the factory survey to convince us that manufacturers cannot meet a 3 percent tolerance on thread without any great difficulty. We had the opportunity of observing the various processes of manufacturing and measuring. We witnessed tests and reviewed exhaustive records pertaining thereto. All such determinations sustained the recommendation we have made, and even indicated, so far as the factory we visited is concerned, that a lesser tolerance than that proposed could be stipulated, at least for measured thread, without detriment to reputable manufacturing interests. However, in recognition of the possibility that other factories within the industry may, have problems both technical and in relation to the human element, that a re difficult to control and may lead to errors more appreciable than any found in the $\mathbf{J}$. \& $\mathbf{P}$. Coats establishment, where we understand the conditions represent the highest standard of perfection presently obtainable in the thread industry, we are influenced to liberalize and not to favor a tolerance below. 3 percent. We now submit these findings for the further consideration and final action of the Conference on our recommendations relating to thread.

Mr. Rogers. An agreement has been reached with the industry to the effect that they will accept the 3 percent tolerance instead of the 
5 percent tolerance that has prevailed for so many years and which was considered by the Committee to be excessive.

(It was moved by Mr. Blickley and seconded by Mr. Fisher that the recommendations of the Committee with respect to thread be adopted; the question was taken and the motion was agreed to.)

Mr. Rogers. Further in relation to thread, I wish to say that the Committee has been shown the finest kind of cooperation by the thread industry. I want to express my personal appreciation and the appreciation of the Committee to Mr. Bell and Mr. Snyder of the Thread Institute. The Committee has reviewed the Model Thread Law developed by The Thread Institute, and the Committee feels that this model law has been well drafted. It is not the function of this Committee to deal with recommended legislation, and so we are respectfully referring this model law to the attention of the Legislation Committee of the Conference for study and for any action which that Committee may deem necessary.

Mr. BeLL (The Thread Institute, Inc.). When I was privileged to address the Thirty-Third National Conference on the subject of thread I pledged, on behalf of the industry, hearty cooperation with your Committee; as has been stated by Mr. Roger's that promise has been converted into performance.

The thread business touches every household in the country. The value of its product exceeds $\$ 150,000,000$ per annum. That business, however, is divided into two important parts, the household trade and the industrial trade. My purpose in speaking to you today is to impress upon you the difference between these two parts. The units of thread that reach the household are accurately measured and plainly marked. Such abuses as have arisen in the past have been developed by the great variety of put-ups that have to be prepared for the industrial trade, from small lengths of surgical sutures for use in hospitals, to 24,000-yard cones of thread used for hemming handkerchiefs.

Great strides have been made by your Committee in two respects: The first of these is the reduction of the tolerance from the 5 percent which was first specified by the State of Connecticut in 1869 , which has also been adopted by other States, and which has guided the industry up to the present; so we are breaking down a barrier which has stood for 80 years. I should like you to remember in connection with tolerances that we deal with all kinds of thread--linen, silk, cotton, rayon, nylon-and it is because of the great difference in the elasticity of these fibers, from about 7 percent for cotton to 28 percent for nylon, that it was not an easy matter to induce some members of the industry to agree to the changes recommended by the Committee.

The second great change advocated by the Committee and incorporated in the proposed model law is having a mark of identification on ever'y unit of thread that is sold. This has been the practice in the household trade, but it has not been a steady practice in the industrial trade.

In conclusion I would like you to know that in addition to the cooperation from the members of Mr. Rogers' Committee, we have been ably counseled by Mr. Smith and by Mr. Baker of New York, a State in which I believe more thread is consumed than in any other State of the Union because of the importance of the garment center in New 
York City. We commend this model law to your consideration, and just as we have cooperated during the past year and a half with Mr. Rogers' Committee we hope to make available to the Committee on Legislation, of which Mr. R. E. Meek is Chairman, all of the data that we have compiled during the time that this subject has been under consideration.

(It was moved by Mr. Fisher and seconded by $\mathrm{Mr}_{1}$. Baucom that the model thread law prepared by the Thread Institute be referred to the Committee on Legislation for study and recommendation to the Thirty-Fifth National Conference; the question was taken and the motion was agreed to.)

Mr. Rogers (reading) :

3. Facial Tissues.-In Item 7 of this Committee's report to the 33rd National Conference in 1947, certain amendments to former recommendations in relation to this subject were proposed.

This item was broken down into four subsections, (a), (b), (c), and (d). Subsection (b), subparagraph (1) of subsection (c) and subsection (d) were fully adopted by the Conference. Subsection (a) and subparagraph (2) of subsection (c) were tentatively adopted by reason of opposition registered by the facial-tissue industry to the proposals they contained, and as a result the Conference went on record to postpone final action on these controversial subdivisions pending further study by the Committee.

Five members, constituting a majority of the Committee, with the cooperation of Mr. Ross Fife, the Executive Secretary of the Tissue Association, proceeded with a survey of a number of tissue mills, devoting four days from July 12 to 16,1948 , to this necessary study in order to reach proper and final determinations. As the result of this effort the Committee obtained and compiled exhaustive data covering the various phases of our observations while engaging on this project, and we are now in a position to submit our decisions on the controversial issues for the consideration of the Conference. Dealing with these in their order, we offer the following:

Subsection (a). This dealt with the recommendation for standardizing sheet count in packages of facial tissues. The reaction of the Committee now is that while standardization of sheet count in packages is favored as a principle, the industry has been able to present and substantiate very logical and sound reasons why there should be no restrictions in this respect because of problems inherent in the production and marketing of their products, the provision always existing, of course, that the actual count shall be declared on packages in accordance with recommendations already adopted by the Conference group. Further in this connection it is the opinion of the Committee that it would be discriminatory to inflict such restrictions upon one industry over another when there is no legislation to govern the standardization of commodities in package form. Our observations have shown us that the tissue industry has many diversified lines and little in the way of consistent uniformity in methods of production, insofar as it relates to packages reaching the consumer. Details in the data that we have compiled clearly illustrate these diversifications.

The Committee, therefore, proposes that the recommendation for the standardization of sheet count in packaged facial tissues presently be discontinued and withdrawn.

Subsection (c) subparagraph (2). The issue in this connection relates to the recommendation of the Committee to govern the inside 
height of boxes or cartons in relation to their contents. Among the subdivisions of Item 7 in our last report this paragraph is the one in which we were most seriously concerned and it has also been proven the one in which the major technicalities exist from a production standpoint. It consequently appears as the result of our findings that the tolerance of $1 / 16$ inch as originally prescribed in the said subparagraph is not sufficient to meet the problems of the industry. It will be recalled that the industry made a counter proposal that the tolerance should be $1 / 4$ inch. The need for this has been substantiated by the findings of this Committee. We, therefore, now recommend that the said subparagraph (2) of subsection (c) as included in our last report be amended to read as follows:

(c) (2) The inner height of boxes or cartons not to exceed tha height of the contents by more than 0.5 inch at $70^{\circ}$ and $75^{\circ} \mathrm{F}$ temperature and 50 percent relative humidity up to and including 200 count, with 0.25 inch added for each 100 additional single sheets.

In the interest of brevity the details of the Committee's findings are omitted from this report because of their volume. They are, however, available for perusal by anyone interested in making an analysis of them and will be produced upon request to your Committee.

(It was moved by Mr. Boyle and seconded by Mr. F. J. Young that the recommendation of the Committee relative to facial tissues be adopted.)

Mr. Callahan. I think the size of the sheet should also be mentioned, and not just count alone.

Mr. Rogers. We already have a regulation, adopted a number of years ago, requiring that the size of the sheets be declared on the package.

(The question was taken and the motion was agreed to.)

Mr. Rogers (reading) :

4. Bar Soap (Bars and Cakes).-This subject was covered in Item 16 of your Committee's report to the Conference in 1947 wherein it was recommended that soap in bars and cakes should be sold by net weight. This would, of course, predicate that when in package form the quantity of contents would be declared, consistent with the principles of net-weight declaration requirements as applied to other commodities.

The soap industry has since reopened the issue by representations to the Committee and requested further study and consideration. They submitted a brief covering their contentions that bar and cake soap should be exempted from sale by weight and marking requirements, basing their arguments mainly on the factor of moisture content, which according to the character and quality of soap as produced for various purposes is variable, and that as a consequence, cakes of soap, identical in weight and character when cut at the factory level, vary greatly in weight when sold to the consumer. Other points of argument presented are:

(1) That is would be impossible to comply with regulations with respect to tolerances when applied to soap in bars and cakes.

(2) That the expenditures required for weight markings on packaged bar soap would add millions of dollars to the cost.

(3) That the public, though charged with this heavy expense, would in no way benefit from net-weight markings on bars of soap. 
(4) That the requirement would create burdens for retailers that might become intolerable.

(5) That nowhere in the United States are cakes or bars of soap required to be sold or marked by weight.

These contentions were exhaustively amplified by supporting data in the industry's brief. They have been fully reviewed by your Committee and, in addition, a subcommittee comprised of two of our group visited one of the outstanding soap-manufacturing plants in the country, that of the Colgate-Palmolive-Peet Company at Jersey City, N. J., for an on-the-spot study of manufacturing processes and procedures inherent in soap production.

The Committee has since had a hearing attended by a representative group from the soap industry and all phases of this question were reviewed. As a concluding argument presented to us at this meeting we were shown two cakes of imported soap-one small and the other about twice as thick. The small one was much heavier for its size than the large one; it seems that it had been loaded with some inert matter having no detergent value, and this sort of thing can be done by anyone wishing to do it. The Committee is now of the opinion that soap is a product which should be treated in a special manner and has concluded that nothing is to be gained for the consumer by requiring sale by weight or by endeavoring to mark the package of bar soap in terms of weight. Therefore the Committee withdraws its original recommendation that bar soap be sold by weight and recommends that no action be taken by the Conference at this time with respect to marking requirements or methods of sale of bar or cake soap.

Mr. Rogers. I move the adoption of the Committee recommendation.

(The motion was seconded by Mr. Ackerman, the question was taken, and the motion was agreed to.)

Mr. Rogers. (reading) :

5. Commodities of Variable Weights in Package Form.-It is recommended that commodities of variable weights, and those that because of their methods of processing do not lend themselves to consistent quantity declarations, when in package form, should be exempted from the requirement of net-quantity markings on individual consumer packages, provided that the legend "To be weighed at time of sale," or other suitable wording, together with the tare weight of the wrapper or container, are plainly and conspicuously marked on each individual package.

This modification of marking requirements shall not apply to the main carrying package in which the individual unit packages are contained for distribution, and such packages shall continue to carry net-weight declarations of quantity.

NoTE.-This recommendation is in line with the thought presented by the Committee in its report to the 1947 Conference, and is in consideration of the difficulties encountered by certain food packers and processors in conforming with net-weight-declaration requirements, such as those where the commodities involved are of variable weights, as in meat and fish products, where the methods of packing are such as to make quantity declarations impractical because of the added labor and expense entailed in individual weighings of packages, which would be passed along to the consumer without any appreciable benefit accruing from a protective standpoint; and also in connection with 
commodities that, due to their methods of processing, contain a high moisture content which quickly nullifies weight declarations, that cannot be consistently maintained for any reasonable length of time in relation to the actual quantity in packages, because of moisture losses. This condition is found in the manufacture of cheese of certain types, and in other products where the commodity is, in any event, weighed at time of sale to the consumer.

With the development of new methods of processing by the meat industry, in which plastic cellulose casings are used, conditions have been created that are complicating in relation to quantity declarations. The progressive trends of packing sources in this connection must be recognized and should be considered. They were not inherent in the situation when net-weight container laws were first placed on the statute books.

It is realized that the recommended departure from strict netweight-declaration requirements will call for special treatment and decisions when packer's of certain commodities dissent from quantity marking mandates. In such instances it would, of course, be incumbent upon dissatisfied interests to prove their inability to meet such requirements, and judgment at official levels must then prevail.

Under prevailing circumstances in certain enterprises, it presently appears that the contentions they have raised in favor of modifications in marking requirements have a foundation of sound reasoning. In their presentations of arguments, they leave no point uncovered to justify their claims, and it is believed that their points of protest have been substantiated by the official observations of weights-and-measures authorities who have had occasion to study them.

Packaged products that readily lend themselves to net-quantity declarations should, of course, never be exempted from the established requirements. The customary practice of weight at time of sale under which certain commodities are sold, should receive full consideration in connection with this issue, and this is entailed in the items specifically mentioned.

Another factor entitled to the fair consideration of regulatory groups is that of the jeopardy in which reputable manufacturing and packing interests can be placed because of conditions beyond their control.

The Committee feels that notwithstanding the value of net-weightquantity markings, there should be some flexibility in the application of such requirements to permit modifications that are worthy and will not detrimentally affect the interests of the consumer, while at the same time eliminating nuisance regulations and "bottlenecks" that produce nothing in economic value, and are more troublesome than they are beneficial.

It can readily be agreed that the commodity packaging situation in our commercial structure has gone far beyond anything that was originally anticipated. We are really living now in a packaging age where most of the essentials we buy are put up in packages of one form or other, and the movement is still growing. It is because of this that we should gear ourselves to thoughts and procedures that are practical and that will serve the best interests of all concerned.

The opinion can well be entertained that the recommendation now offered should be beneficial to consumer interests, as it leads back to the time when consumers had their commodities weighed right at the counter where they purchased them, and, therefore, sustained no 
shrinkage losses, which are now so often entailed in packaged essentials.

Mr. Roper. I move that the Conference indefinitely postpone consideration of this proposal.

(The motion was seconded by Mr. Baucom.)

The Chairman. Is thele any discussion?

Mr. Baucom. Practically every State has a net-weight marking statute. We cannot here recommend violation of those statutes, nor can we here change the laws of the States requiring net-weight declarations of commodities in packaged form. We might recommend that each State repeal or change its law, but that would be different from what is now proposed. I think the proposal is something which we camnot carry out by legal methods.

Mr. BAкEr. I agree with Mr. Baucom. The Committee proposal would be contrary to the law of New York State.

Mr. Bougmner. Michigan has a law requiring foods in packaged form to carry net-weight declarations. As I understand this proposal, some foods would be exempted from that provision of our law, so I do not feel that Michigan could support it.

Mr. Baker. It seems to me that this would be a step in the wrong direction, and that we would be nullifying the progress that we have made. We would, in effect, be saying to the manufacturer, "If you can prove to us that you have a product that it is rather difficult for you to mark we will just let you go ahead and sell it the way you want to sell it and we will place on the retailer the responsibility for marking."

Mr. Roper. Commodities can be sold in either one of two ways-by weighing over a scale in the presence of the customer, or by marking the package with a guaranteed net weight. 'This proposal is neither fish nor fowl. It would throw the net-weight laws wide open. There is also the Federal Food and Drug law that requires net-weight declarations. This proposal would confuse the whole issue.

Mr. Rogers. I am surprised that no one from industry has anything to say on this question, because the idea originated with industry; you remember the discussion at the last Conference by representatives of the fish industry, when it was claimed that the net-weight marking of packages of fish would materially increase the price to the customer. The Committee holds no brief for any industry and still believes in our net-weight marking laws, but there do seem to be situations in the commodity structure today which will make it necessary sooner or later to give consideration to such a proposal as is now offered.

Certainly the burden of proof should be on the industry to show that quantity declarations would be detrimental in some fashion. If prices can be kept down by weighing a commodity at the time of purchase by the retail consumer, that would be worth while.

Mr. Kanechman. I think Mr. Roger's is right. Health Departments are requiring dealers to put plastic or cellophane covers on meat that is exposed where customers can handle it, and the time may be coming when all such meat will have to be wrapped for sanitary purposes. I do not think there will be any harm done by adopting the Committee proposal. I think that this Conference should put some faith in its Committees. The gentlemen of the Commodity Committee have put in a lot of time on these matters. I believe that they will think of the 
welfare of the sealer of weights and measures, and I think that most of their recommendations should be accepted by this Conference.

'THE SECRetary. As information, and apropos of the suggestion that packages of certain commodities can be put up in standard-sized packages, I should like to read to you a portion of an editorial in the March 1949 issue of Packaging Parade. In this editorial reference is made to a particular packer, to which I shall refer as "Company X":

A new customel-size 1-pound package of frozen fish has been announced by Company X. This Company reported that the new 1-pound package resulted from a general demand by housewives for a uniform-weight package of frozen fish which would aid them in recipe planning. Currently, Company $\mathbf{X}$ has in national distribution 1-pound packages of ocean perch and cod. Following within the next month or two will be 1-pound sizes of flounder, haddock, and mackerel. Company $\mathrm{X}$ has retained the traditional cellophane-wrapped fillets of rarious sizes for customers who want to buy in larger amounts.

My purpose in reading this extract is to support Mr. Rogers' statement that not all commodities that lose moisture would necessarily be subject, under the recommendation of the Committee, to the general exemption from content marking and to the requirement for weighing at time of retail sale. I believe he has made a point of the fact that many of these commodities could be packed in standard-size packages or in packages the weights of which could be properly declared.

Mr. BAKER. I would like to remind the Conference that at our last meeting the fish packers said that conld not be done. I knew it could be done, because I had seen packages that were being put up in that manner by one particular company. Since then I have counted three different companies that are doing that, and there is only one, to my knowledge, that has not yet standardized its package. That is a sample of what "could not be done."

Mr. Rogrrs. The Committee had before it the other day the question of certain items of cheese. For example, Ricotta cheese is in package form and is put up with holes in the container to allow the whey to drain off; a net-weight declaration on such a package does' not mean a thing, and this commodity is sold by weight at the time of sale. Another type of cheese, called "Mozzarella," is made from skim milk and is put up hot; boiling water is poured over it and while the cheese is in a plastic state it is formed into balls and quickly covered with cellophane. 'There is no uniformity at all in these individual units and they could not be weighed-the product has to be handled too hot. If it were marked, the marking would mean nothing the next day. It is weighed at time of sale.

Mr. Linio. I come from the area where this cheese is manufactured. The product is put up in cartons and weighed and the wholesale invoices are correct, but there are no weight markings on the individual packages. The $31 / 2$-pound cans as put up at the plant are invoiced at 3 pounds and in many cases contain 31/4 pounds or more of cheese; this is necessary to meet the requirements of the law of such a State as Pennsylvania. It is not fair to compel a manufacturer to give that excess quantity.

In the case of the Mozzarella cheese, this is displayed in the retail stores in display cans, and I believe it is always weighed at the time of sale because there are few people who buy a whole can.

Mr. Butcklex. If this recommendation were adopted bv this Conference, Pennsylvania could not put it into effect unti] we changed our law. 
Mr. McBride. What I like about the Committee's reconmendation is the last paragraph which states that the adoption of its recommendation would lead back to the situation where weight is determined at the time of sale. 'That is a very desirable way of determining quantity. The marking of food in packaged form with net-content declarations is not an accommodation to the consumer or to the weights and measures official; it is an accommodation which the packer himself seeks. If the packer cannot accommodate his package to certain marketing requirements-and it may well be that because of the nature of the commodity he cannot do so-then I think it is a desirable thing to do what the Committee recommends, requiring the retail stores to sell these commodities by weight, the weight being determined at the time of sale.

I cannot say that it is any advantage to the consumer to buy food in packaged form and marked as to net contents; this does not always bring about the accuracy we should like to get. Under the proposal of the Committee there would be no problem of shrinkage. If under this proposal there is greater probability that the consumer is going to get more nearly the quantity she pays for, I think the proposal has merit. The National Conference is not a legislative body, but its recommendations are helpful if we seek to make amendments to our statutes.

(The question on the indefinite postponement of consideration of the recommendation of the Committee with respect to "Commodities of Variable Weights in Package Form" was taken by a rising vote. The validity of the vote was questioned by Mr. Kalechman on the ground that some who were not delegates to the Conference may have voted. The Chairman then directed that a vote be taken, in which those favoring the notion would assemble and pass by the tellers to be counted, following which those opposing the motion would be similarly counted. As tellers, the Chairman designated Mr. Dietz, Mr. Morgan, and Mr. Laurie. By direction of the Chairman Mr. Laurie announced the result of the ballot; this was affirmative 37, negative 38. Accordingly, the motion to postpone indefinitely was lost.)

(It was moved by Mr. Fisher and seconded by Mr. Becker that the recommendation of the Committee be adopted. The question was taken, and the motion was agreed to.)

Mr. Rogers (reading) :

6. Roofing.-It is recommended that a standard of measure for roofing be established on the basis of coverage, in terms of the "square" or the "square foot," and that it shall be sold or quoted only on the basis of these terms defined as follows:

The term "square" shall mean a quantity of material sufficient, when applied as intended by the manufacturer in accordance with design and/or specifications, to cover an area equal to $100 \mathrm{U}$. S. standard square feet exclusive of side laps or side joints, and that if the material is of corrugated design, the side lap or side joint shall be one full corrugation.

The term "square foot" shall mean a quantity of material sufficient, when applied as intended by the manufacturer in accordance with design and $/ \mathrm{or}^{\circ}$ specification, to cover an area of $1 \mathrm{U}$. S. standard square foot exclusive of side laps or side joints.

Note.-With no uniform method of measurement or sale to govern it, roofing has presented troublesome problems not only to consumers but to weights and measures officers as well. Some of these materials are sold on the basis of coverage and others by measurement in terms 
of their own area with no allowance made for overlapping. This situation has frequently led to misunderstandings and controversies between dealers and consumers, especially in connection with metal roofing material, among which aluminum might be cited because of the popularity it has gained since the war, presumably by reason of the quantities that became available out of war-surplus stocks. Weights and measures men are drawn into cases where the most common complaint is that the consumer bought certain types of roofing by the square only to find that it would not cover the generally accepted area of a "square," or 100 feet, when nailed down with the laps. Manufacturers of rolled or sheet aluminum have admitted that their product was sold on the basis of its own area and that purchasers were supposed to figure how much additional material they would need to take care of laps or joints. This hasn't helped the purchaser who had previously bought his roofing on the "coverage" method of measurement.

This recommendation is, therefore, offered for the promotion of uniformity and equity and to eliminate the confusion that now exists in the purchase and sale of roofing materials.

(It was moved by Mr. Baucom and seconded by Mr. Christie that the recommendation of the Committee with respect to roofing be adopted. The question was taken, and the motion was agreed to.)

Mr. Rogers (reading) :

7. Wiping Clothis. (Washed and Unwashed).--Should be sold by net weight, and when put up in bales, cartons or other containers, the net quantity of contents should be plainly and conspicuously marked on the package.

Mr. Rogers. In the Tentative Report of the Committee we proposed an alternative method, and I will read from the Tentative Report:

An alternative method of sale by gross weight could be allowed without detriment to purchasers, providing the gross weight, and the tare weight of the container inclusive of other foreign matter, such as cleats, strappings and bindings, are plainly and conspicuously declared on the package, the said markings to serve in lieu of net quantity declarations.

A tolerance of 5 percent should be provided for uncontrollable weight deviations due to the regain and loss factors inherent in wiping-cloth materials under conditions of commercial handling.

NOTE.-The term "wiping cloths" comprehended in this recommendation shall be construed to mean scrap textiles of nondescript character and of irregular form or size.

The Committee is now recommending the deletion of those parts of its original recommendation which I have just read, and confines its recommendation to the original first paragraph providing for sale by net weight.

Representatives from the Sanitary Institute of America, representing the wiping-cloth industry, appeared before the Committee. We found that all wrappings and bindings were being included in the gross weight of a package. It was claimed that the Federal Government was buying on the gross-weight basis. We have since received authoritative information to the effect that the Federal Government, and especially the Navy, is going to the net-weight method of buying wiping cloths.

(It was moved by Mr. A. T. Smith and seconded by Mr. Boyle that the recommendation of the Committee with respect to wiping cloths be adopted.) 
The Secretary. In my capacity as Secretary of the Conference I have received a telegram which $I$ wish to read to you at this time. It is signed by Peter Di Biaso, Chairman, A. Merwin Godfrey, and J. Milton Hagy, Jr., Committee on Weights and Measures of the Sanitary Institute of America. The telegram reads as follows:

We should greatly appreciate having this statement read to your delegates in conjunction with the Report of your Committee on Methods of Sale with reference to wiping cloths (washed and unwashed).

The Sanitary Institute of America is the National Trade Association of Wiping Cloth Manufacturers. A Committee of our Association met with your Committee on Methods of Sale on Monday, May 23. At that time we pointed out that a large percentage of wiping-cloth sales are interstate sales direct from manufacturer's to consumers; that such interstate sales are not subject to regulation by State or city officials; and that, therefore, there is no reasonable likelihood of achieving uniform enforcement of a net-weight practice on both interstate and intrastate transactions.

Let me interpolate by saying that the next paragraph will be read as it appeared in the telegram received, and then I shall read what I think mas intended to be said. The wire reads:

Your Committee on our opinion affords equal protection to the consumer and which might reasonably be expected to be uniformly adopted throughout the industry.

That sentence is obviously garbled, and $\mathbf{I}$ think what was meant was this:

Your Committee's alternate proposal, in our opinion, affords equal protection to the consumer, and this might reasonably be expected to be unifolmly adopted throughout the industry.

"That is my personal interpretation. Now, to go on with the telegram:

Your Committee's alternative proposal reads as follows:

"An alternative niethod of sale by gross weight could be allowed without detriment to purchasers, providing the gross weight, and the tare weight of the container inclusive of foreign matter, such as cleats, strappings, and bindings are plainly and conspicuously declared on the package, the said markings to serve in lieu of net quantity declarations. A tolerance of 5 percent should be provided for uncontrollable weight deviations due to the regain and loss factor's inherent in wiping-cloth materials under conditions of normal handling."

We agree with your Committee on Methods of Sale that this alternative plan could be adopted without detriment to purchasers. In addition the alternative plan, if adopted, may reasonably be expected to be uniformly put in practice in both intrastate and interstate transactions. If this alternative proposal is adopted, our own association will cooperate fully with entorcement officials toward the end that the regulation be universally and uniformly adhered to.

For these reasons as well as for the other reasons set forth to your Committee on Methods of Sale we strongly urge your Conference to adopt the alternative proposal outlined in the Tentative Report of your Committee on Methods of Sale.

\title{
The Chairman. Are you ready for the question?
}

('The question on the adoption of the recommendation of the Committee with respect to wiping cloths was taken and the motion was agreed to.)

\author{
J. G. Rogers, Chairman, \\ R. S. ACKERMAN, \\ C. D. BaUCOA, \\ J. F. BLICKLEY, \\ J. A. BOYLE, \\ L. R. ROPER, \\ F. J. Young,
}

Committee on Methods of Sale of Commodities. 
TESTING PROCEDURES FOR VEHICLE-TANK COMPARTMENTS

REMARKS OF. J. M. DIETZ, SUPERINTENDENT OF WEIGHTS AND MEASURES, COUNTY OF UNION, N. J.

After corresponding or talking with a number of officials of various States connected with weights and measures departments, oil companies, and departments of revenue, I find that there are many different ideas as to the correct procedure and equipment for testing vehicletank compartments, as I found that each person with whom I communicated had his own idea, which differed mole or less from the others.

For instance, I found that the standards used for testing compartments consisted of the following: 1-, 2-, 5-, 10-, 24-, 25-, 50-, 100-, 200-, 300-, 400-, and 500-gallon test measures, and using different combinations of the same, with the majority using 1-, 5 -, and 50 -gallon, or 1-, 5-, and 100-gallon standards.

The 50- and 100-gallon measures were about equally divided as to stationary overhead, dropping the liquid into the compartment, and portable, pumping the liquid into compartment, while the larger standards were almost always stationary and used overhead, so that the liquid could be dropped into the compartment being tested.

One department has four permanent calibrated stations and two portable units. All of these mits are equipped with one calibrated measure unit that drops from $1 / 2$ to 24 gallons, and one each 25-, 50-, 100-, 300-, and 400-gallon measure units. The two portable units are mounted on platform on truck; this platform with all testing equipment can be elevated by means of hoist on truck to a point higher than tank to be tested, enabling the operator to drop the water used for testing into compartment. Water for testing is obtained from fire hydrants.

In a fer instances meters were used for testing, some gravity and some pump type, these being tested with 50-gallon or larger test measure before and after making the compartment test.

The majority used water for the testing medium where measures were used as the standard for testing. One used a meter for measuring the water used in testing. One used kerosene as the principal medium, occasionally using No. 2 fuel oil. One used solvent as testing medium, which was measured through a meter. The rest used No. 2 fuel oil for testing in both meter and measures.

The minimum expansion space allowed in compartments varied greatly. One allowed 0.50 per cent, and about one-third allowed 0.75 per cent; one-third allowed 1 per cent, and two allowed 2 per cent. The rest allowed according to the distance hauled-0.75 per cent or 1 per cent for distances up to 50 miles, 2 per cent for distances from 50 to 100 miles, and 3 per cent for distances over 100 miles and for interstate shipments.

Almost all stated they used wire-and-lead seals for sealing the marking indicators.

Approximately 90 percent said they started with an empty compartment and measured the liquid as it was being put into the compartment; the rest started with full compartment, measuring the liquid as it was drawn from compartment. In a few instances the compartments were gauged and chart furnished, showing the measure- 
ment in inches and to the sixteenth of an inch for each 10, 25, or 50 gallons of the capacity of the compartment.

Where compartments were equipped with safety valves, approximately 75 percent tested with the valves closed. However, in two States the State law required that the safety valves be open when testing and the lines included in capacity of compartment.

Two said they tested compartments, where there was no meter to deliver through, with safety valves closed; where there was a meter for delivery the safety valves were open and wet lines were included in the capacity of the compartment. The rest tested with safety valves open.

There were only a few who made a separate test of the lines from safety valves to ontlet valve of line.

Before beginning a test of the compartments, we make an inspection of the complete tank to see that there is no sludge, metal filings, or other foreign matter in same that might injure the pump or meter of equipment, or possibly prevent an accurate test being made, as we have found several tanks which had so much sludge, metal cuttings, and dirt in them that it was impossible to make an accurate test of same before they were properly cleaned.

We check all valves and pipe lines to see that they are in proper working order and comply with specifications in National Bureau of Standards Handbook H29, 1942.

In Union County, New Jersey, we have found over 50 vehicle tanks which had their pipe lines and valves so arranged, that part or all of the fuel passing through the meter could be diverted back into the compartment or to the pump and again pass through the meter without going out of the hose nozzle. All of these tanks were condemned until all bypasses were removed.

We inspect the compartments to see that they are well vented and that there are no pockets to hold fuel which cannot drain from compartment when vehicle is on a level surface, in accordance with specifications in Handbook H29.

As the majority of vehicle deliveries are made where it is practically impossible to have the vehicle on a level surface, I believe this specification should be changed. My recommendations are to have it read,

When vehicle is standing upon level surface, or on a grade of $10 \%$ or less, complete delivery may be made from any compartment.

As this would practically eliminate the greater hazard of having volatile fuels, such as gasolines, which failed to drain from compartiments when vehicle was unloaded while standing upon a grade, being mixed with kerosene or fuel oil which might be the next delivery made from this compartment, as well as to insure complete delivery to the purchaser, especially from large compartments. It is my belief that the safeguard to life and property which would result from this change would more than offset any additional expense which might be necessary to manufacture vehicle tank compartments to comply with this recommendation.

In the majority of our tests of meters and compartments, we use our 1-, 5-, and 50-gallon Seraphin test measures, which I consider entirely too small for this work, as there is a greater likelihood of making an error, as the smaller the units used in testing the more measurements are necessary to complete the test and more time is needed to do the work. 
We use water for testing compartments during warm weather, and No. 2 fuel oil in cold weather. Meters are tested with the same kind of liquid that they are being used at the time to measure, making at least two tests on each meter. For testing large-capacity meters we use a calibrated compartment of 660-gallon capacity.

In testing transport and large-capacity tanks we have been very fortunate in having good neighbors in the adjoining County of Middlesex, where Charles F. Sullivan is the Superintendent of the Department of Weights and Measures. He has graciously extended to us the privilege of using their tank-compartment and meter-testing equipment. Their equipment consists of two vertical cylinders, each having a capacity of 200 gallons, marked in gallon graduations. These cylinders are mounted on a stand about 15 feet high, which is higher than the top of all tanks. As the contents of one cylinder is being drained into the compartment, the other cylinder is being filled from an underground supply of No. 2 fuel oil. With this equipment a 6,000 -gallon tank can be tested in approximately $21 / 2$ hours.

When making a test we begin with an empty compartment with the safety valve closed, filling the compartment to the required expansion space of not less than 0.75 percent of capacity of compartment, setting the marker to the nearest gallon mark, and sealing it with wire-andlead seal with our aluminum seal attached, measuring the distance to the nearest one-sixteenth of an inch from bottom of marker to top of fill opening.

If the line has a shut-off valve at the end we close it and open the safety valve, and when line is filled from the compartment we measure the liquid required to bring the level of liquid in compartment to the sealed marker, giving the owner certificate showing capacity of compartment with safety valves closed and also with safety valves open.

It is my belief that the ideal testing 'equipment for testing vehicle tank compartments and meters in a county such as Union County, New Jersey, with an area of approximately 105 square miles, would be to have two measures having capacities of 200 gallons each and two cylinder measures with capacities of 25 gallons each and graduated in onetenth gallons, all of the measures to be mounted upon a platform with their base 15 feet above a level strip of concrete that is large enough to hold our largest tractor and tank units, the measures to be so arranged as to permit the emptying of one or more into a compartment while the other measures are being filled from the supply tank, the supply tank to be located above ground and containing 7,000 gallons of No. 2 fuel oil. With this arrangement the average compartment could be tested within 15 minutes and a 6,000-gallon tank within 2 hours, and as the liquid supply and the tank compartments would be of about the same temperature, there would be very little change in the volume of the oil while tests were being made. This would eliminate the danger of having a meter or compartment damaged by water used in testing, especially in cold weather.

The Chamman. The second portion of this program item was to have been presented by Mr. J. W. Sinclair, of the Central Committee on Automotive Transportation, American Petroleum Institute. Mr. Sinclair is unable to be with us and his paper will be presented by Mr. G. W. Laurie, Chairman of the Central Committee on Automotive Transportation. 
PAPER OF J. W. SINCLAIR, CENTRAL COMMITTEE ON AUTOMOTIVE TRANSPORTATION, A. P. I. PRESENTED BY G. W. LAURIE, CHAIRMAN, CENTRAL COMMITTEE ON AUTOMOTIVE TRANSPORTATION

I am very appreciative of the opportunity of addressing your 34th National Conference. Your very high standards of public service are equaled only by your historic willingness to cooperate with those many industries who, in their various enterprises, are also engaged in serving the public in a vending capacity. Our appearance before you today is evidence of this spirit of cooperative approach to the solution of common problems.

As "Huckster's" we have learned that public respect and confidence is a most valuable economic asset. We have also learned that this respect camnot be had merely through good intentions but must be backed up by concrete evidence that the ultimate consumer is, to the best of our collective abilities, getting value received both as to quality and quantity.

I say "to the best of our collective abilities" advisedly, for perfection in measurement has not as yet been attained in practical operation. Our inventive genius and operating know-how is progressively reducing the tolerance to which we work, and from year to year ways and means are devised to overcome the pervelsity of inanimate objects and the frailties of human nature. 'There is also present, however, the danger that, in our eagerness to give the public full value, we may in reality be working away from such a goal in imposing upon ourselves such rigid standards that the cost of enforcement and compliance (ultimately paid for by the consumer) reach disproportionate amounts.

In other words, if the consumer has to pay ten cents for nine cents worth of protection, he fares more favorably under protection requirements of lesser rigidity. Your Conference is to be complimented upon their past and, we trust, continuing recognition of this fundamental principle in the form of practical tolerances.

In the field of distribution of petroleum products in the bulk we encounter many obstacles in our quest for closer approach to perfection, not the least of which is the calibration of vehicle tanks used as measures. Although it is true that the increasing use of meters on loading racks and on the vehicles themselves has progressively reduced the extent to which the vehicle tank is used as a measuring medium, large quantities of petroleum products continue to be moved in receptacles which also constitute the sole medium of measurement. 'This is especially true in larger movements from refineries or terminals to intermediate distribution centers, wherein such movements involve a relationship between the manufacturer (or shipper) and the transporter (or motor carrier by tank vehicle). Such movements being over relatively long distances, the economics of transportation demand tanks of the largest capacity possible consistent with our ability to load, to transport over the highways, and to unload at destinations. In these larger quantities the tolerance factor is compounded and becomes of vital concern from the standpoint of practical compliance ability.

Our concern, however, is not confined to the procedures incident to calibration and testing. These procedures have been discussed with you at this and previous conferences and we have faith in our collec- 
tive ability to solve them in a manner calculated to best serve public interest. Once differences have been resolved, we hope that a degree of uniformity can be achieved throughout the several States so as to remove existing impediments to movements over State lines. These current impediments are not confined entirely to varying State requirements but they are frequently encountered in a somewhat lesser degree between counties of the same State.

Owners of trucks have been interested for many years in a uniform procedure for the calibration and subsequent testing of tanks used as liquid measures. A review of our interest and activities in this respect may be of interest:

1. On March 15, 1944, American Petroleum Institute members interested in traffic and automotive transportation recommended the creation of a Joint Committee on Tank Truck Slipping Practices. One of the recommendations of this committee was that there should be developed a standard for the calibration and testing of vehicle tanks.

2 . The Committee made certain suggestions for changes in the section entitled "Vehicle Tanks" of National Bureau of Standards Handbook H29 of 1942. On June 18, 1946, our Central Committee on Automotive Transportation met in Washington and Mr. R. W. Smith, Secretary, Committee on Specifications and Tolerances of the National Conference, generously offered to discuss with us informally the problem of establishing a national standard for the calibration and testing of velicle tanks. We learned at that time that such a standard would supplement the specifications appearing in Handbook H29 and that, while it could conceivably be produced by our industry, there would, of course, be no assurance that it would find national acceptance.

3. On September 24,1946 , this conclusion was set forth in a paper presented to the Thirty-Second National Conference on Weights and Measures by the Director of the Division of Transportation, American Petroleum Institute, Mr. James E. Moss, who said, "Above all, it was our feeling that implicit in this problem was a testing procedure recommended by an authoritative body as standard, and I understand that the National Conference has recognized specific procedures for the testing of certain types of measuring devices."

We have not lost hope that an appropriate committee of this Conference would establish such standard procedures for calibrating and testing vehicle tanks and we have in the meantime informed ourselves with respect to various procedures currently used so that we might be in a position to assist with this undertaking if and when it was inaugurated.

4. At the Annual Meeting of the Institute on November 11, 1946, we adopted a program calculated to broaden our understanding of the work which had already been done in this field and to inform our membel's of the equipment and methorls being used by certain State oficials who liad given special attention to vehicletank calibration.

Accordingly, on December 2, 1946, we sent to our membership a list of 15 articles appearing in the Ploceedings of the National Conference on Weights and Measures and a list of 21 State oficials who had shown special interest in the vehicle tank calibration problem. Thereafter, several of our members called on these officials who were located near them to secure their views with respect to the establishment of a standard for calibrating and testing the tanks of vehicles. Sevelal valuable comments and information as to methods used were secured as a result of these visits.

5. In March 1947, one of our members, Mr. Frank Baird-Smith, prepared a paper entitled, "Truck Tank Caliblation," which was presented at the 11th Anuual Convention of the Northwest Weights and Measures Association. This paper sets forth the problems of calibration which confront the tank truck owner and how they are currently met.

6. On September 23, 1947, our Director of Transportation again presented a paper before your $33 \mathrm{r}^{\circ}$ National Convention which reported the progress we had made during the year in preparing ourselves to assist in the work under discus- 
sion. At the 33rd National Conference, other valuable papers on the subject of relicle tanks were presented by Messrs. Archie T. Smith and George E. Carpenter, botli State officials, and Allan R. Smith, Executive Secretary, National Truck Tank and Trailer Tank Institute. We reproduced these papers and sent copies to all of our members on September 25 th.

7. In August 1948, we received the good news that your Secretary, Mr. R. IV. Smith, was to receive more assistance in the Department of Weights and Measures of the National Bureau and that it might now be possible to prepare for circulation the Handbook on "The Testing of Measuring Devises," on which Mr. Smith had labored for many years.

This was good news for us for such a handbook approved by this Conference and published by the National Bureau of Standards would assure national acceptance of the testing methods recommended.

8. At our Annual Meeting in Chicago last November, the possibility of securing the approval of the National Conference for undertaking the preparation of a tentative draft of a handbook on Testing of Measuring Derices was fully discussed by our Central Committee on Automotive Transportation and the following action was taken:

"The Committee were of the opinion that such a project would be of great value generally and particularly that section of it which might deal with the calibration of vehicle tanks. The committee went on record as extending to the National Conference and to the Committee on Specifications and Tolerances and Mr. R. W. Smith their full cooperation in the preparation of the section of such a publication which would relate to the calibration of vehicle tanks and they asked to be informed as to how their cooperation could be made most effective."

This action of our Central Committee was transmitted to Mr. R. W. Smith on December 9 th of last year.

9. On March 21st, this year, we completed our comments on the "Tentative Diaft, Revised Section-VEHICLE TANKS-National Bureau of Staudards Handbook H29 (1942)" and transmitted them to Mr. R. W. Smith.

I believe the foregoing recital of activities on the part of the American Petroleum Institute largely speaks for itself and reflects onr attitudes. Prior to your current Conference, and in the course of this Conference, we have had the privilege of reviewing with you certain of your proposals to reduce in pronounced degree existing tolerances. These proposals have caused us great conceln. When our comments on the "Tentative Draft," above refer'red to, were transmitted to $\mathrm{Mr}$. Smith, Mr. Powelson, Chairman of our Engineering Committee, said in part in his covering letter:

Our greatest concern with respect to the proposed revision relates to the reduction in tolerances. We are anxious that accuracy in the measurement of our products be of the highest practicable order. We believe that the tolerances proposed can in time be met. We are convinced, however, that, before the present tolerances are changed, there should be developed a nationally accepted procedure for the testing of measuring devices. We do not believe that tolerance per se has any significance except to the extent that testing procedure insures it. Since we have no nationally accepted testing procedure, we feel that the changing of existing tolerauces is out of order. We, therefore, urge the Committee on Specifications and Tolerances to first develop a nationally acceptable procedure for testing of measuring devices and, when the measuring technique therein set forth is understood by those responsible for calibration, that then the tolerance be changed. If such a program is adopted, it will have our full support.

I solicit the most earnest consideration by the National Conference of Mr. Powelson's remarks. I make only one addition thereto. In the establishment of these testing procedures, the stern realities of practical application should be given cognizance, as no procedure will be of benefit to the public unless and until facilities for practical application are available. The practical application of the testing procedure in turn commands consideration of enforcement and compliance cost. We must remember that our mutual obligation to the purchasing public is twofold. We must not only issue full measure, but give full 
value for the protective dollar which we spend in the public's belialf, in the realization that it is the public that stands this cost either in the form of the purchase price or the tax bill, or both.

Mr. LAURIE. I think, had Mr. Sinclair been here this afternoon and listened to your proceedings, and had he heard how you gentlemen fight just as much to take an unfair regulation off the manufacturer as you do to impose a regulation on a manufacturer in the interest of the general public, he might have said: "Gentlemen, we have many problems, we have much to learn in the near future. We are not perfect. We are pleased, however, with the opportunity of being accorded the privilege of working with you gentlemen to try to overcome these deficiencies which we recognize exist at the present time."

I am sure that if we work together in the future as we have in the past, we shall have nothing to worry about in the way of having regulations imposed upon us that we cannot meet, and the public will have nothing to worry about in the way of not getting their full measure.

\section{CARE AND USE OF STATE PRIMARY STANDARDS}

\section{REMARKS OF W. S. BUSSEY, ASSISTANT CHIEF, OFFICE OF WEIGHTS AND MEASURES, NATIONAL BUREAU OF STANDARDS}

A major part of the program of the Office of Weights and Measures of the National Bureau of Standards during the past year has been the resumption of personal visits to State and local weights and measures offices, this being in addition to attendance at and participation in State and regional weights and measures conferences. It has been my privilege, and I might add my very great pleasure, to make a majority of these visits. It has been both educational and inspirational to me, and we feel that these visits have been constructive and that they have been appreciated by the officials contacted.

I should like to take this opportunity to express the appreciation of the Bureau and my own personal thanks for the fine reception accorded us and for the generous hospitality extended everywhere we went. It would be difficult, indeed, to locate a finer group of people engaged in any endeavor, or a group more sincerely interested in the task they are responsible for performing, than are weights and measures officials. Whether it be day, night, Saturday, Sunday, or holiday, you men have been eager to discuss your problems and to learn everything you can about weights and measures activities in other jurisdictions. You have evidenced an almost unanimous desire for cooperation, and for achievement of greater uniformity and efficiency in weights and measures administration throughout the country. This fine spirit is most commendable.

We have found a general trend toward improved field-testing equipment. Especially is this true in the fields of large-capacity scales and wholesale meters. States, counties, and cities have spent and are spending many thousands of dollars for this type of equipment. We have also fonnd a general trend toward more adequate training for inspectors. Most jurisdictions are trying to give their men more and better training before sending them out on their own. A good example of this is the new Louisiana Department. The entire force of inspectors in that State were given weeks of intensive training before being sent out alone. Some departments are carrying on continuous training programs among their men. A few examples are the District 
Department here in Washington, the City of Detroit, and the City of Seattle. This type of training might be classed as "on the job" training. It is certainly worth while and is producing fine results.

In practically all of our visits, one topic which was sure to come up for discussion has been the subject of my talk to you today, that is, "Care and Use of State Primary Standards." Could there be a more important topic to discuss with a weights and measures official? I think not, but I am afraid that it is a subject which too often we are prone to neglect. I am sure that when we stop to think about it, we all realize that the primary standards maintained by the National Bureau of Standards, provide the very bedrock of the foundation supporting the weights and measures structure of this country. We also realize that just as the primary standards at the Bureau form the foundation for the weights and measures structure of the Nation, so do the primary and other reference standards of a State form the foundation for the weights and measures administrative organization in that jurisdiction. The real object of weights and measures administration is to transfer the known value of authentic reference standards, through a series of tests, comparisons, and observations, to commercial weighing and measuring equipment and ultimately to all commercial quantity determinations. Regardless of how efficient a field inspector may be, he cannot transfer true values to cominercial channels unless the authenticity of his reference standards is properly established and is known at all times.

You are familiar with the old adage of "the man who lived too close to the forest to see the trees." Sometimes I think that is our trouble regarding many important matters; we live so close to them that we fail to appreciate their real value and importance. We simply get into the habit of taking too many things for granted. It is my opinion that this is the case, in some instances, regarding our State reference standards.

I am sure we will all agree that it is essential for each State to have complete sets of primary and secondary reference standards, and that each must have the necessary balances and other laboratory equipment, in order to support an efficient enforcement organization. Another necessity, if this type of precision equipment is to be shown proper respect and is to be maintained in authentic condition, is a suitable room or laboratory in which to house it properly. This should be a separate room to be used for this purpose only. No one should be granted access to this room except when accompanied by a staff member properly trained in the techniques of handling and care of precision reference standards.

I have visited State offices possessing this type of laboratory facilities, with the standards housed and maintained as I have just described. Furthermore--and this is significant-I found these very State officials planning further improvements in their set-ups.

But not all State Offices are properly equipped. It is true that this type of equipment is relatively expensive and that it is not always easy to get a State Legislature, a Board of County Commissioners, or a City Council to appropriate all of the money that is needed by the Weights and Measures Department. These improvements often have to be made piecemeal, or in gradual steps and over a considerable period of time. However, I think that it is incumbent upon each and 
every weights and measures department head to strive continually toward the achievement of the desired goal, in this particular field. If we cannot get everything we need at one time, let's get a little at a time, selecting the most urgently needed items first, and adding item after item, until the job is completed. If serious and consistent efforts are made, superiors can be convinced of the importance of, and absolute necessity for, adequate reference standards. 'To illustrate this, let me relate an experience on one of my most recent visits. One of the first things that the Chief of the Division pointed out to me was that he did not have the essential mass reference standards and smaller balances; he said that he had made numerous requests for this equipment, but had been repeatedly turned down. He had a new Commissioner and wanted me to talk to him about this matter. We did talk to him, with the result that the Commissioner made a hurried check of available funds for the remainder of the current fiscal year and found that he could spare a few hundred dollars for this purpose. This amount was not sufficient to purchase everything that was needed. But it was adequate to purchase essential "Class B" weights and possibly one small balance. The Commissioner promised to do all he could to add more equipment next year. To improve the set-up in this State still further, the Chief of the Weights and Measures Division is now negotiating for a desirable room to house his laboratory. If this effort is continued, within a few years there will be a fully equipped, firstclass weights and measures laboratory in this State. This is the sort of progress that is pleasing, and is typical of what we are endeavoring to do to encourage and assist State and local departments.

There is another point which can well be considered for a moment. A department may have all of the necessary reference standards and other laboratory equipment, adequately housed and maintained, but all of this will go for naught, unless the equipment is properly used. It is not reasonable to expect that it will be properly used by any person who does not have a satisfactory appreciation of this class of equipment, or one who is not properly instructed in this type of precision work. One way in which such appreciation and skill can be acquired has been provided by the Bureau in the form of the short course on the calibration of standards, conducted in the laboratories and lecture rooms of the Bureau. This course was offered twice in 1948 and 16 students completed it. Ten students attended the first class in March and six attended the second class in October. It is unfortunate that every State having a weights and measures enforcement organization, and each of the larger county and city jurisdictions, could not have had at least one representative attend this course. Whether or not the course will be repeated will depend upon the demand for it.

Another thing which should prove to be a very valuable asset, if it is used extensively by weights and measures officials, is a printed Circular which the Bureau is preparing at this time. The title of this Circular will be, "Calibration, Use, and Maintenance of State Standards of Weights and Measures." "It is being prepared by Dr. L. V. Judson, Chief of the Length Section of the Metrology Division. It should be ready for distribution within a few months. This new Circular will include a description of, and specifications and tolerances for, Class A, B, and C weiglits, as well as other standards. It will describe briefly how various standards of length, mass, and capacity 
are calibrated at the Bureau of Standards. It will deal with the proper maintenance and care of, and respect for, precision reference standards in the State office. It will also explain the proper calibration of secondary and working standards, at the State level. This is the type of calibiation work which was taught in the short course, and is the type of laboratory work which must be done in any wellorganized State office. This will be the first time that all of this information has been made available in one Circular and will be the first time that some of it has ever been released in printed form. Much credit is due Dr. Judson and the Metrology Division for this constructive publication, and I sincerely trust that weights and measures officials throughout the United States will make full use of it.

In conclusion I should like to leave the following suggestions with you, and I urge that you give them your full and careful consideration :

1. See that your State has or gets the necessary primary reference standards of lengtl, mass, and capacity, and the essential balances and other laboratory equipment.

2. See that your State, and the larger county and city offices therein, have or get the necessary secondary standards, including proper balances, etc., for the local offices.

3. See that a proper room is provided to house your standards and equipment and to serve as your laboratory.

4. See that the persomel of your department has the proper knowledge of, and respect for, precision standards and equipment.

5 . See that at least one person in your organization is properly trained in the technique of using precision standards, balances, etc.

6. See that your State primary reference standards are submitted to the Bureau for test and certification, at legular intervals, as required by your state law. This is required once every ten years, in many States.

7. See that your State, county, and city secondary and working standards are tested regularly, in your State office, as provided by your State law.

8. Finally, in addition to what you do in your own immediate jurisdiction, take adrantage of every opportunity to encourage officials of other jurisdictions to improve conditions in their own teritories. Thus, improvements throughout the United States can be brought about. Then and only then can weights and measures officials be proud of, and the general public lave full confidence in, the foundation upon which we are attempting to erect our weights and measures edifice.

\section{REMARKS OF W. W. BOUGHNER, SUPERVISOR, DIVISION OF WEIGHTS AND} MEASURES, STATE OF MICHIGAN

I feel highly honored in having been selected to take part in this Thirty-Fourth National Conference on Weights and Measures. In following Mr. Bussey on the topic "Care and Use of State Primary Standards," I wish to take advantage of this opportunity to say a few words in commendation of the trairing extended through the National Bureau of Standards Schools on "Calibration of Standards."

Fortunately, I was able to attend one of these classes, being a student in Class No. 1 from March 1st to 12th, 1948. Quite often, during my present routines, $I$ find myself pondering over the many incidents that occurred during those few short weeks that were so profitably spent here in Washington. I still have a vivid recollection of the eagermess and enthusiasm of the students and the patience and perseverance of members of the faculty.

These thoughts awaken some lather unexplainable emotions, for instance: Imagine yourself again yearning to carry apples to your teacher after abstaining for over half a century. 
On my return to routine weights and measures duties as Supervising Inspector, I found that I was able to verify the correctness of my primary standards as certified by the National Bureau of Standards to the fourth and even fifth decimal. Such proof has tended to give me much satisfaction and confidence in the results of my official calibrations and I have re-calibrated some forty of our field inspectors' weights and measures equipment and corrected many errors not previously apparent. I now have a record in the Lansing Weights and Measures Laboratory of the true value of each and every inspector's weight and measure including those calibrated for some thirty County and City Sealers in Michigan. Such records could prove of great value in contested court actions. Within the past month we have recalibrated twenty 1,000-pound test weights which we had previously found necessary to transport periodically across several State lines to the nearest National Bureau of Standards testing installation.

We were able to secure an old, precision balance of 1-ton capacity which had been made to order for Jackson County and had not been in active use. This was reconditioned, the ratio of its arms determined by the use of 1,000 pounds of 50 -pound weights which had been carefully sealed to an average tolerance of less than 1 grain each, and we found that we could consistently determine the value of each 1,000-pound weight within less than 1 ounce. What was equally important, we could prove it by authentic records.

Although Michigan does not rank among the leading petroleum producers, we do have 16 petroleum refineries and being practically surrounded by navigable water, most of the larger oil concerns have established one or more boat tanker terminals on our shores for receiving, storing, and re-shipping their' products. 'This development of the petroleum industry has caused an enormous shift in the type of weights and measures services demanded. For instance, the fuel which was formerly measured by the cord in pioneer days and later weighed by the ton is now squirted through pipe lines and volume determined by meters or liquid-measuring devices. We must be prepared to properly calibrate such wholesale and retail devices.

I have found my National Bureau of Standards training of great value in making such calibrations and urge all State, County, or City Inspector's who may be called upon to test wholesale meters or proving tanks to avail themselves of the National Bureau of Standards. course of training.

(At this point, at 5:30 p.m., the Conference adjourned, to meet at 9:30 a. m. Friday, May 27, 1949.) 


\section{SIXTH SESSION-MORNING OF FRIDAY, MAY 27, 1949}

(The Conference reassembled at 9:40 a. m., Robert Williams, Vice President, presiding.)

\section{COMMODITY TOLERANCES}

\section{By R. K. Slodgh, Sealer of Weights and Measures, City of Akron, Ohio}

The topic "Commodity Tolerances" has always aroused controversy when and where weights and measures officials meet. In view of the limited time at my disposal I will confine my remarks to those commodities sold by weight. Problems with commodities sold by liquid measure have been solved by proper packaging, and the remaining ones are already subject to specific regulation or will be discussed separately by this Conference.

Up to the turn of this century, most commodities were weighed or measured in the presence of the purchaser. This practice caused few problems, other than the accuracy of the weighing and measuring devices used, and the integrity of the merchant. Since then the increasing trend has been to prepackaged commodities, first by the merchants and now more and more by the producer, manufacturer, or distributor.

Unethical practices on the part of some of these people caused the Federal Government and most of the States and cities to pass laws requiring quantity declaration in terms of net weight, measure, or count, and also caused weights and measures officials to be steady users of aspirins and hair dyes. Prepackaging also brought forth the terms "Commodity Tolerances," and "Natural and Unavoidable Shrinkage."

After accepting the invitation to talk on this subject, in order to get a cross-section of views and the benefit of experiences of others, I made out a questionnaire and sent it to many active State, county, and city weights and measures officials from Maine to California, from Seattle to Jacksonville, from Houston to Minneapolis, and many points between. Comments were invited on the following questions:

1. Does your State (or city) recognize or have quantitative tolerances on commodities?

2. Has your State (or city) established a table of shrinkage allowed on certain commodities?

3. Do you unofficially recognize a tolerance on commodities?

4. Do you believe that the National Conference on Weights and Measures should establish quantitative tolerances on commodities?

5. Would weights and measures enforcement of net-weight laws be made less difficult if tolerances on commodities were established?

The replies were prompt (many by return mail) and the comments, some several pages in length, were enlightening and revealed the evident interest and concern about this subject. From them come these conclusions:

Six States contacted had, after much study, adopted commodity tolerances, or tables of allowable shrinkage. 
All city and by far the majority of State and comty weights and measures officials are opposed to commodity tolerances, or tables of allowable shrinkage, and do not believe the National Conference should establish commodity tolerances.

Practically all officials unofficially recognize a tolerance on packaged commodities. They realize that mechanical and human elements enter into packing and distribution, that some errors will occur, but that these errors will be as often above as below the correct figure. They believe tolerance is not a one-way street.

Many officials believe that if commodities can be packed to tolerance, they can be packed to net weight. A few officials have heard rumors that new packaging materials are now available which will eliminate shrinkage.

Most officials express a fear that if commodity tolerances are established, packers will pack to the tolerance instead of net weight or measure. Their fears seem to be justified, because officials, in States where tolerances are established, complain about packages always in deficiency to the maximum of tolerances allowed.

On the subject of commodity tolerances, honest differences of opinion occur as to the best way to cope with it. Several hard-working and sincere officials of a few States have decided, after long study, that it might be better to establish tolerances on commodities or tables of shrinkage. This is usually done by regulation in either of two ways: (1) By a fixed percentage allowance or by a definite allowance per pound, or (2) by examination of each commodity separately and establishing a tolerance based on the findings. I do not propose to attack the decisions of the officials in the States which have established commodity tolerances. However, I do not agree with them.

If tolerances are allowed, it must be recognized that some commodities will shrink or lose moisture content more than others, and an allowance by fixed percentage or by pound would be definitely unfair and would satisfy few. To examine each commodity and establish tolerances by merit would be an endless task and I, for one, would not want the responsibility. It would lead to endless recriminations, jockeying, and lobbying by groups and individuals to promote greater tolerance for their particular commodity. It might lead to the requirement that the weights and measures official, in addition tc his regular tools and equipment, take along with him laboratory equipment with which to make a test if he found a package short weight. Or can you imagine a poor merchant having to run a moisture test to convince a housewife that the $43 / 4$ pounds she got, instead of 5 pounds, was legal and legitimate and not short weight. I do not believe that this housewife or any purchaser of commodities will be satisfied with anything but full weight or measure.

Winston Churchill once stated that he was not elected Prime Minister to supervise the liquidation of the British Empire. I believe weights and measures officials are appointed to see that the public gets what it pays for and that we should not sell our bosses (the citizens of our communities) short, by being a party to any act which would recognize shrinkage as justified, no matter how strong the argument. To establish commodity tolerances, or tables of shrinkage allowed, is to legalize short weight or measure. 
We all know that the Food and Drug Administration has established unpublished tolerances, and that the packers of the different commodities do know what they are. We are constantly confronted with this statement, "The Federal Government allows us this much shrinkage, therefore you should also allow the same amount." The local or State official has no jurisdiction outside his own territory, and can only base his findings and opinions on what he sees. If he finds shortages in commodities he has no way of determining how much was packed originally.

In all fairness, it must be recognized that some excessive shrinkage is beyond the control of the packer, and is directly attributed to improper or too-lengthy storage, or poor merchandising practices by the retailer. I believe these facts are always taken into consideration by the inspecting official.

I believe that when producers, distributors, or individuals undertake to package commodities for sale to consumers, they should also assume the same responsibility for correct weight or measure at the time of sale, as does the retailer, if he packages a commodity prior to sale. Many packers or processors do recognize that their products are subject to shrinkage, and have made conscientious efforts to eliminate, control, or make allowances for this shrinkage. These packers must be protected against unfair competition by others with less ethics.

Now we come to problems of those packers who claim that shrinkage is natural and unavoidable and would cost them too much to overpack to allow for shrinkage. On hearing these claims over the years, one wonders if they are not made to justify present practices. One of the rules of advertising and propaganda is that if a statement is made over and over again it will eventually be accepted as truth by the masses. I believe that too many packers of commodities have become propaganda victims of those weasel words, "Natural and Unavoidable Shrinkage," and have not devoted enough research to better packaging by the use of newer and modern materials.

This brings up the question, "Can shrinkage be avoided?" Several officials, in reply to my questionnaire, mentioned hearing of new developments in packaging materials which would eliminate shrinkage. With the limited time at my disposal I have not been able to check on these new products on a national scale, so in mentioning that with which I am familiar, it is not my intention to slight anyone or any product, and I only hope that other's here can further enlighten us. We need to be informed on these items.

Our chemical engineers and research men have made remarkable progress along this line and have arranged and rearranged atoms and molecules, much as the army drill sergeant does with rookies, and have brought forth materials which will revolutionize the packaging of commodities. During the past 25 years we have become familiar with Du Pont's Cellophane and some of its 50 or more varieties. I also understand that Du Pont has announced a new material, Polythene (made by the polymerization of etlyylene gas), which is moisture-proof and offers great possibilities for packaging, but is in limited production at this time.

Coming from Akron, Ohio, the Rubber Capital of the world, I am familiar with some of the research and use of our locally made products. All of our major rubber companies have made great strides in $858144-50-11$ 
the production of plastic films and coverings; however, at this time ouly one of our local firms has gone into extensive production of plastic material for commodity packaging. 'The Goodyear Tire \& Rubber Company developed a product called "Pliofilm" which has been in use for a number of year's, and although the demand exceeded supply, they have collaborated in extensive research and field work with a number of leading universities and also with major chain-stores and individuals. Recent plant expansion has enabled Goodyear to announce the availability of Pliofilm as a packaging material in the trade publications.

Pliofilm is a rubber hydrochloride film which is transparent, moisture-resistant, and if required, permits the proper flow of gases to prevent metabolism break-dlown; can retain or keep out moisture; has a tensile strength of 2,800 to 4,000 pounds per square inch, yet has the basic elastic properties of a rubber band; is resistant to punctures, tears, and abrasions; and can be sealed by heat, adhesive, or by sewing. At the present time it is being used nationally in packaging potatoes, onions, lettuce, and other vegetables, apples, oranges, and other citrus fruits, dried fruits, cheese (natural and processed), meats, meat products, oleomargarine in the quick mix bags, crackers, cookies, cake mixes, dried soup mixes, fruit cakes, etc. It is also being used extensively all over the country to package commodities in self-service stores. Our department has check-weighed many of the items in the past few years and $I$ am also familiar with the results nationally.

Packers, and the manufacturers of packaging materials, are interested in the preservation of products as well as the elimination of shrinkage. This is readily understandable because we know that in many products the loss of moisture also lessens consumer's acceptability of the product. We as weights and measures officials, of course, are mainly interested in the elimination of shrinkage, and I know that you will be very interested in some of the astounding results obtained by the use of pliofilm in the packaging of some controversial commodities. The use of pliofilm in packaging shows these results:

In produce such as celery, cabbage, cucumbers, red peppers, etc., the shinlage has been reduced 90 to 99 percent. In conjunction with this it might be well to note that, as an example, cabbage in cold storage went 37 days before showing a 1 pelcent loss in weight. On the retail stand it went 15 to 18 days before losing 1 percent.

Prunes and other dried fruits took 60 days before 1 percent loss in weight could show.

The weight loss on oranges was cut two thirds-a saving of orer 8,000 oranges per carload to the packer, a fresher, more juicy orange to the consumer. Where a 3-ounce orange overpack was necessary in the conventional 8-pound-package container, only one is necessary in pliofilm.

Frankfurters showed one-haif of 1 percent loss in 18 days.

Ever have trouble with meat? The loss in red meats was so negligible that it had to be measured in terms of weeks instead of days. To you who have had trouble checking prepackaged and fresh meat shipments, these findings seem almost impossible.

Butter-a very troublesome item. In storage 15 weeks packed in pliofilm, butter shows a weight loss of only two-tenths of 1 percent at 40 percent relative liumidity. At 75 pelcent relative humidity the weight loss was only one-tenth of 1 percent.

These are only a few of the examples of how proper packaging will practically eliminate shrinkage, and certainly proves that it can be done now. Probably other's here can give us more information on packaging materials. 
I have tried to cover the problems of commodity tolerances and shrinkage and also how they can be solved. I know that some of you have something to say on this subject. This is your chance. Let's make our decisions now.

The Chamran. Mr. Slough, is this new wrapping material expensive, or is it going to come into general use in the near future?

Mr. Slodgr. It is not as cheap as some, but when you consider the elimination of shrinkage, it is very cheap. For instance, I think it is normal to get from 3 to 5 percent shrinkage in bulk meat shipments from Chicago; by the use of this wrapping material that costs about 14 cents, that entire loss has been eliminated.

\section{REPORT OF THE NATIONAL CONFERENCE COMMITTEE ON SPECIFI- CATIONS AND TOLERANCES, PRESENTED BY J. P. MCBRIDE, CHAIR- MAN, AND DISCUSSION THEREON}

(SECRETARY's Note.-In the presentation of this Report, references are made to the "Tentative Report", widely distributed by the Committee in advance of the Thirty-fourth Conference. Actually, as presented to the Thirty-fourth Conference, the Committee Report consisted essentially of recommendations for modification of the Committee's 'Tentative Report, although there was necessarily involved action by the Conference upon the Tentative Report as modified by the recommendations contained in the "Final Report" of the Committee, the latter being a document which was available to the Conference at the opening of the meeting on the morning of Tuesday, May 24.

Because of the length of the Tentative Report, the technical portion of which comprised over 100 pages of mimeographed material, it has been found impracticable to publish the full text in this Report, as would ordinarily be done. The introduction to the Tentative Report, howerer, is presented in full, this being substituted for some of the extemporaneous remarlss made by the Committee Chairman when the Report was presented to the Conference. There is also presented in full the introduction to the Final Report of the Committee.

National Bureau of Standards Handbook H41, Specifications, Tolerances, and Regulations for Commercial Weighing and Measuring Devices, will contain the revised specifications, tolerances, and regulations as finally adopted by the National Conference; this Handbook should be available for distribution prior to the issuance of the Report of the Thirty-fourth National Conference.)

\section{INTRODUCTION TO THE TENTATIVE REPORT OF THE COMMITTEE ON SPECIFICATIONS AND TOLERANCES}

Herein is the tentative report of your Committee on Specifications and Tolerances. You will note that it includes a full text of a proposed revision of Handbook H29 together with other material which has been added by the Committee since the last Conference as a result of suggestions received from Conference members and on the Committee's initiative.

One of the features of the new revision is a section on General Requirements which covers in general all classes of weighing and measuring devices. It slould be borne in mind that complete coverage of a problem will have to be found in consulting the General Requirements and in addition thereto the Special Requirements in relation to the particular type of device in question. In Handbook H29, the same specification might run in several codes, and in order to eliminate this repetition, the specification will appear in the General Requirements Code only. This not only simplifies the code, but also shortens it. For example, in the code covering computing scales in $\mathrm{H29}$, there are eight specifications; whereas, in the proposed revision, there are but three specifications in the computing scale section of the Scale Code, the other five having been merged either in the General Requirements or general scale specifications.

You will also note new paragraph headings, and that these are consistent through the General Code and the Special Codes and run in the order of Application of the Code, Definitions, Specifications, Notes in relation to procedure in special tests, Performance Requirements, Tolerances, and Regulations, the paragraphs being identified as $\mathrm{A}$ for Application, $\mathrm{D}$ for Definitions, $\mathrm{S}$ for Specifications, etc., corresponding to the categories above mentioned. 
It has been felt by the Committee that there has been for some time a growing desire on the part of the Conference members to have the specifications and tolerances simplified: This, as you may well appreciate, is no easy task, but the Committee has, nevertheless, attempted to accomplish this much-desired result, appreciating that simplification would contribute greatly to uniform enforcement.

In eudeavoring to accomplish this simplification, it has been necessary to make some changes in the existing codes and the Committee has weighed these changes with the thought in mind that any surplusage should yield to simplification if at all possible. This is particularly true in the Scale Code wherein it was felt that there were possibilities of confusion, and accordingly, much time and effort were deroted to this code. It is suggested that you make a careful comparison of the existing code with the changes and improvements in the proposed code. The Committee believes that it has effected a major simplification of the statement of scale tolerances, particularly with respect to large-capacity scales. Among other things, you will note that some new table groupings are proposed and in some instances where tolerances are now related to actual SR, changes have been made so as to relate these to specific values. In this processing it may well be that some tolerance refimements have been lost, but your Committee feels that these are not too material against the advantage obtained by the simplification accomplished.

Illustrative of the scope of this work are the following comments: The entile text of H29 was carefully scrutinized in relation to nonretroactive specifications with the iclea in mind of reducing the nonretroactive category of the existing codes to the barest possible minimum. We now have in this nonretroactive category all or part of General Specifications G-S.1., G-S.4.2.3., G-S.4.4.3., and G-S.4.5., one liquid-measuring device specification, eight scale specifications, and one scale regulation.

In the Milk Bottle Code, we have eliminated Tabie $\mathrm{C}$ entirely as this table now serves but little purpose, and rather than present three tables as formerly, the tolerance schedule is now set up in one table on average capacities with the individual bottle tolerance set forth as not greater than four times the tolerance provided on average quantities. The Lubricating Oil Bottle Code is practically unchanged. The Measure-Container Code has but one change in the definition of the term. We have added an entirely new code to be known as "Tentative Code for Cordage-Measuring Devices." This corle covers electric wire, cord, and rope measuring machines and follows the pattern in the code on fabric-measuring devices except that the tolerances are more liberal.

In the levision of the Code on Scales, among the changes which have been suggested is to delete that part of present computing-scale specification $\mathrm{D}-2 \mathrm{~b}(1)$ and general specification $\mathrm{B}-2 \mathrm{~m}$ (4) which permits the additional indicator for the purpose of correctly positioning the eye in relation to the true indicator. This is an old proviso and has been vely little utilized and experience has shown that in some cases when the true indicator has been damaged or removed this auxiliary indicator has been used as the principal indicator. Therefore, in view of the above, it would appear a proper conrse to eliminate this additional indicator.

In present general scale specification B-2m (4) on uncompensated spring scales, the clearance between the index of the indicator and the reading face is now restricted to a maximum of 0.12 inch. This has been reduced in proposed scale specification S.2.5. to a maximum of 0.09 inch. In all cases save the above, these clearances for scales nsed in ordinary trade are set at 0.06 inch; the present clearances on uncompensated spring scales have been twice this distance, and we see no good reason for this great disparity between the two and consequently have rednced the distance as noted.

On livestock scales, a suggested change is offered in the definition so as to strike out the words "on the hoof" as appearing in present general scale definition A-2s (2) and substitute in place thereof the words "standing directly on the scale platform." This will be found in new scale definition D.1.13. This new phraseology is offeled as language more specific because situations have arisen wherein livestock contained in motor vehicles offered argument as to whether such animals were "on the hoof," and this new language leaves no doubt.

Two new scale regulations are offered-R.15., having relation to accessihility of scales for testing purposes, and R.16., in relation to assistance in testingoper: tions. Both of these matters have been discussed for some time, and your Committee now feels that the subject is of sufficient importance to require spelling 
out a regulation in relation thereto as a necessary aid to the officials in the proper performance of their duty.

We have also added a new general regulation in relation to all weighing and measuring devices under the caption "Maintenance of Equipment," which is proposed as Regulation G-R.2.

Present scale regulation K.5., "Suspension of Hanging Scale," has been amended and is now offered as Regulation R.3., adding after the word "suspended" the words "flom a fixed support."

With the advent of high prices on foodstuffs, computing scale manufacturers have endeavoled to increase the price range on their scales to accommodate the scale to the present market conditions within the available linear space on the chart and existing specifications in relation to width of indicator, width of graduations, and width of clear interval between graduations, which represents quite a problem. Magnification has helped in this solution but it, too, has limits beyond which clarity of reading camnot be maintained. The existing general scale specification B-2m(3) covers width of weight indicators, and computing scale specification $\mathrm{D}-2 \mathrm{~b}(1)$ provides a maximum width of 0.015 inch for indicator with no provision in relation to magnification. Present computing scale specification D-2c(2) provides a minimum width of graduation as 0.008 inch (which is qualified when magnification is employed) and a maximum width not greater than the width of the minimum clear interval between graduations. Present computing scale specification $\mathbf{D}-2 c(3)$ sets up a minimum clear interval of 0.04 inch between weight graduations and 0.02 inch between value graduations (which is qualified when magnification is employed).

One of the difficulties in manufacturing processes has been the arbitrary dimension of maximum width of the indicator, and while it was contemplated that the remedy might lie in providing, when under magnification, that the width of the indicator sliall be reduced in inverse proportion to the angular magnification of the lens system, it was found that this could result in an indicator wire too fine for readability, and your Committee has resolved the problem in proposed general specifications G-S.4.2.3., "Width of Graduations," and G-S.4.3., "Clear Interval Between Graduations," which retain the essence of the existing code in relation to these phases, and further proposes an entire new general specification G-S.4.4.3., "Width of Indicatol," which relates the width of indicator to the graduations and the clear interval.

We also offer a new general specification G-S.4.5., "Requirements when Indications are Magnified," providing that minimum width of gladuations, minimum clear interval, and maximum clearance between the indicators and reading face shall be of the dimensions in the existing code but shall be reduced in inverse proportion to the effective angular magnification of the lens sistem in a vertical plane, determined when the eye of the observer is 12 inches from the graduations. (This specific definition of angular magnification is new and is regarded as sound from the standpoint of optical design.) This specification further requires that the angular magnification be marked on the scale. Further in this specification is language covering scales in which the indications are magnified and projected by an optical system onto a sereen and are not directly viewed as magnified by a lens system, and this language applies the existing minimum dimensions for width of graduations and clear intervals to the projected images.

In the Dry Measure Code, we have extended the tolerance table to include the capacities $1 / 8$ pint, $1 / 16$ pint, and $1 / 32$ pint, or less, to covel special situations in relation to sale of seeds by dry measure.

In the Vehicle Tank Code, a new proviso has been added to existing specification 15, "Diversion of Measured Liquid," and trill be found as proposed S.20.2., which pernit's under certain conditions two or more delivery outlets beyond the meter. It has been found in some circumstances of delivery, accessibility to the receiving vessel will be greatly aided by allowing two or more delivery outlets.

Existing vehicle-tank specification 17, "Constancy of Delivery," has been amended and is proposed as N.2.1., "Discharge Rates for Meters," the principal change being in setting up a 15 -gallons-per-minute minimum rate on vehicle tank meters of a rated size of less than 2 inches, and 20 percent of the manufacturer's marked maximum rate on meters of the rated size of 2 inches and larger.

In proposed vehicle-tank specification P. 1., "Operating Conditions for Meters," we have carried over part of the language in existing specification 17 and have alded a new proviso in relation to multiple compartments discharging through 
a manifold to a common line to the meter with a special added tolerance. This type of installation, as your experience has shown, is susceptible to the perpetration of flaud by means of the manipulation of the pump and line valves which can create excess air induction. While it may be algued that this is not a normal use of the facility, it is, nevertheless, a use that is easily possible, and the added tolerance is in line with our establisled policy of special tests and appears to be justifiable as this type of installation sevelely tcsts the efficiency of tile air eliminator. It theretore appears to your Committee to be a fair procedure to double the limit of error under thesc conditions of installation, and if the unit cannot be made to meet this condition, the situation can be corrected by selective valve control so that but one compartment line can be opened at one time during the process ot delivery.

The tolerances on vehicle-tank compartments used as mcasures have been materially reduced both on first tests and on subsequent tests, and you will also note that it is proposed that the tolerance on wholesale meters, which includes vehicle-tank meters, have been reduced by onc-half with the operative date of the proposed tolerance deferred until July 1, 1950. This proposed reduction in tolerance is ofiered in answer to the suggestions of many weights and measures officials. The existing tolerance of one cubic inch pel indicated gallon has for some time been recognized as too liberal and a number ot States have departed from this tolerance and are operating under a tolerance approximating the proposed new tolerance. Weights and measures officials in fact have been very slow to meet this problem of proper tolerances on so-called wholesale meters. The fact that we liave anything approaching accuracy is due to the cooperation of industry with those States which lave been sufficiently forward-looking to procure adequate testing equipment, and there is a growing number of such States.

Vast quantities of petroleum products ale measured through meter systems, and in the northeast section of the conntry, in additiou to gasoline, we have tremendous quantities of heating oils so sold. In this area, we early felt the necessity of acculacy in these devices and the commodity has reached an appreciable price level. No. 2 oil retails at twelve cents and up per gallon and No. 1 range oil at fourteen cents and up per gallon. This type of quantity determining system presents a different problem to the meter industry than is the case with the scale industry. Delivery of the product entails involved methods of piping to carry the product and herein lies a great part of the problem. Meters are necessarily sensitive and we have the inherent problem of air induction on pressure-operated systems and this can be aggravated by the human element.

We must, therefore, look to protective features minimizing susceptibility of the system to the perpetration of fraud and we must go berond the measuring element and include as part of the whole system, the piping and accessories. We cannot meet the problem with a standby attitude and your Committee feels it would be derelict in its duty unless specific recommendations were now offered, and hence we offer these recommendations with a deferred operative date set as July 1, 1950. This mcans that there will be an intervening National Conference between the acloption and the effective date of the suggested revision.

The delay in proposing a new tolerance has been occasioned by the fact that many of the jurisdictions are without adequate equipment to properly test this type of device, but it is now felt that improvement has been effected in testing equipment, and while much more improvement needs to be accomplished it has been felt that the deferred date of operation will afford opportunity to officials to properly equip themselves with testing facilities so that they can accurately test within these tolerances.

The remaining codes are essentially unchanged. Inasmuch as it is anticipated that the Conference members will carefully compare the existing code with the proposed changes, the foregoing remarks are not intended to cover every detail of the revision and changes, merely serving as a general statement of the whole. The Committee will be glad to receive any turther suggestions or other changes, but request that the same be submitted in writing at the earliest possible date so that ample time may be given the Committee to study these suggestions before the Conference opens.

The entire document which is presented in succeeding pages is recommended to your most careful scrutiny and study. In fact, the purpose of furnishing copy well in advance of the Conference is that you may have opportunity to individually study the contents. It is hoped that this method will expedite Conference procedure and concentrate discussion on matters which your study suggests as your well-considered differences of opinion. 


\section{'Table of Con'texts}

General Code

Linear Measures

Fabric-Measuring Devices

Tentative Code for Cordage-Mieasuring Devices

Taximetel's

Odometer's

Liquid Measures

Graduates

Measure-Containers

Milk Bottles

Iubricating-Oil Bottles

Liquid-Mcasuring Devices

Grease-Measuring Devices

Velicle Tanks

Dry Measures

Beiry Baskets and Boxes

Scales

Weights

\section{INTRODUCTION TO THE FINAL REPORT OF THE COMMITTEE ON SPECIFICATIONS AND TOLERANCES}

There are enumerated in what follows the cllanges which the Committee on Specifications and Tolerances recommends be made in tle Tentative Report of the Committee. These changes result (1) from careful studies of the tentative material issued some time ago, made by the Committee on its own initiative, (2) from consideration of much written comment which has reached the Committea from a valiety of sources, and (3) from extensive hearings which have been held by the Committee in Washington, beginuing on May 20, at which representatives of equipment manufacturer's and industrial users of equipment have appeared and offered constructive comment and suggestions.

What is now recommended to the National Conference represcnts, in some instances, the correction of errors and omissions, and in other instances, a compromise between conflicting riewpoints. The Committee has not been able to concur in all of the suggestions made, but it believes that it has met all of the major problems presented to it. The Committee feels that its recommendations are sound, it requests a sympathetic reception of its proposals by all parties at interest, and it proposes to the National Conference the adoption of its Tentative Report as amended by what follows in this Final Report.

$$
\begin{aligned}
& \text { J. P. McBride, Chairman, } \\
& \text { G. F. Austix, Jr., } \\
& \text { Nalls berryan, } \\
& \text { C. M. FulLer, } \\
& \text { R. IV. SMrtir, }
\end{aligned}
$$

Committec on Specifications and Tolerances.

Mr. McBride. During the year the Committee has received communications from the membership of this Conference, and eventually issued its Tentative Report which was distributed considerably in advance of this meeting to weights and measures oflicials and to various sections of industry concerned with the several codes. The introduction to the Tentative Report included a request that suggestions or criticisms in the minds of Conference members or representatives of industry be conveyed to the Committee so that it might reconsider the material during the Committee sessions to be held immediately prior to the opening of this Conference.

The Committee sat for several days, begimning last Friday morning. Extensive hearings were held at which representatives of equipment manufacturers and industry appeared, and the Committee spent many hours in executive sessions reaching its decisions which are embodied in the Committee's "Final Report." Thus in the two documents in 
your hands, the 'Tentative Report and the Final Report, the former being modified by the latter, you have the final recommendations of your Committee. The purpose of this procedure was to permit all interested individuals to study the bulk of the Committee's recommendations in advance of this meeting, so that the matters that the Committee has to present at this time, in modification of its Tentative Report, might be lightened.

The Committee is acting upon the assumption that proposals in the Tentative Report of the Committee are acceptable to the Conference except in those cases in which we have received suggestions for changes or comments indicating disagreement. In order to expedite consideration by the Conference I shall, therefore, proceed upon the stated assumption, and shall confine my explanatory comments to the items. of the Final Report of the Committee proposing amendments to the Tentative Report. [Reading:]

\section{SECTION ON GENERAI CODE}

G-A.1. In line 7, after the word "charge," add the words, "or payment". Change the final period to a colon and add the following:

Provided, That for the purposes of this paragraph, production-incentive payments, wages, or bonuses which are supplementary to the regular wages of employees. shall not be construed as "payments for services rendered."

Mr. McBride. 'The addition of the words "or paynent" would make the entire phrase read, "or in computing any charge or payment for services rendered on the basis of weight or measure." "This change is desirable in order to bring definitely within the category of "commercial" equipment such equipment as is normally used for determining wage payments.

A "production incentive" differs from a basic wage. An industry might set a certain quota for certain branches of its activity and may agree with the employees involved that an increase of production above the quota will qualify the employees for a bonus or additional payment. 'The principal pay of the employees would be determined on a per-hour basis or by some other method, but the bonus payment would be based upon production records determined, for example, over an industrial scale, entirely suitable for production purposes but not subject to commercial recuirements and possibly not conforming to such requirements.

We felt that the equipment regularly used for production purposes could safely be used for determining the amount of the production above the established production quota, this amount being the amount used in arriving at the production-incentive bonus. The bonus would be a small part of the total payment to the employee, and we considered that if we were to demand compliance with commercial requirements on the part of production equipment this might defeat the purpose of industry in speeding up production and work to the financial disadvantage of the wage earner: ${ }^{6}$ [Reading:]

G-A.2. Delete this paragraph, and renumber the three paragraphs following.

Mr. McBride. The Committee recommendation for the deletion of original paragraph G-A.2. is based upon the criticism that the language in question might suggest to a weights and measures official

${ }^{6}$ See also the paper of Mr. H. M. Roeser beginning on page 96 of this Report. 
that it gave him anthority over non-commercial equipment which otherwise he would not have. The code, of course, is not creative of any authority that does not already exist, as defined by the statutes under which oflicials operate. The deletion of the paragraph will not, of course, take away any authority or power that an oflicial has under his statutes. To eliminate the possibility of confusion the Committee recommends deletion of original G-A.2. [Reading:]

G-A.3. (original number) Change the final period to a comma and add the following :

and when equipment designed for special purposes is examined, due consideration shall be giren to the design and to the conditions of use of the equipment.

Mr. MCBride. This addition is to emphasize the importance of the official giving proper consideration to the design and conditions of use of special equipment which he is called upon to examine. [Reading:]

G-A.5. (original number) Add at the end of the paragraph the following:

The tolerances on metric equipment, when not specified herein, shall be equivalent to those specified for similar equipment constructed or graduated in the customary system.

Mr. McBrine. The purpose of this change is to bring into the new code certain H29 language which was inadvertently omitted. [Reading :]

G-S.4.3. Insert a comma at the end of line three and add the words, "not less than 0.03 inch for weighbeam graduations,". In line five, change "S.4.5." to "G-S.4.5."

Mr. McBride. It appears that weightbeams have been developed which are not in conformance with the old requirement for a clear interval of 0.04 inch between weighbeam graduations, a condition brought about, perhaps, by some lack of alertness on the part of officials in enforcing that particular requirement. However, we have felt that there is some merit in reducing this requirement from 0.01 inch to 0.03 inch in the case of weighbeam graduations. In the ordinary reading of a scale equipped with a weighbeam, the operation is slower than in the case of the reading of an automatic-indicating device, and necessitates, for accuracy, that the reader be closer to the indicating element. In the opinion of the Committee 0.03 inch does afford sufficient clear interval to give clarity of reading, because of the closer application of the reader to the reading element.

The change in the citation is to correct a typographical error. [Reading:]

G-S.4.5. In line eight, insert a period after" the word "graduations" and strike out the underlined material which follows.

Mr. McBride. The material which it is recommended be stricken out is that which reads, "and this effective angular magnification of the lens system shall be marked in such a position that the marking will be readable when the device is assembled for use." The Committee felt that there was merit in its original recommendation but that there was also merit in the criticisms received from several sources; the Committee's decision finally hinged on the question of the in formative value of this type of marking to the inspector in the field. Lells magnification is closely releated to the clear interval between chart graduations, and it is important to the official to know the power of the lens because our ability to check is confined to determining the distances on the 
flat chart and then utilizing the magnification figure to ascertain whether or not the specification requirement is met. The scale manufacturer will furnish any official with a statement of the magnifying power of his lens, so even with the deletion now recommended by the Committee the official can have the needed information on lens magnification, getting this by letter or statement from the manufacturer. This information is primarily for the official, and the Committee feels that it is immaterial whether the official gets it in a statement from the company or in a statement affixed to the scale. [Reading:]

G-T.2. In line two, change "T.1." to "G-T.1."

Mr. McBride. This recommendation is to correct a typographical error.

If you wish to take action code by code, we have now concluded our Report on the General Code.

(It was moved by Mr. Leonard and seconded by Mr. Rogers that the General Code as presented by the Committee be adopted.)

Mr. Crawrord. Referring to $\dot{\mathrm{G}}-$ S.4.5. and the deletion recommended by the Committee, I do not believe that there is a city sealer in the United States, with the possible exception of a few of the largest cities, that has information on the magnifying power of computing scale lenses.

Mr. McBride. You can get it on request.

Mr. Crawrord. Do we have to write for it? We should not have to request the manufacturers for it. We do not know what we have unless we have a laboratory and tear down the scale.

Mr. McBrine. Even if the magnification were marked on the scale you would still have to take somebody's word for it, because you still would have considerable difficulty determining whether or not the statement were correct.

Mr. Crawford. I know, but I have contended that we should have a statement on the scale to show us what the magnification is. It is a matter of giving us something to work from intelligently.

Mr. Greene. In Connecticut, when a scale company applies for approval of a chart or a scale, it makes a statement to the type-approval authority giving all required information. Such information is: certainly furnished to me and must be furnished to everybody else.

Mr. Bauconr. I would like to commend the Committee for the good work they have done. Every one of us remember's distinctly the difficulty we have had in interpreting certain sections of H29. However, I wish to refer to paragraph G-A.1. as proposed to be amended. I cannot agree with that amendment. Why should not a man's supplementary salary be just as accurate as his basic salary? If I am goingto pay a man so much per day plus a bushel of oranges, why should not that bushel of oranges be correct? I therefore move that that amendment be deleted.

(At this point there ensued a lengthy discussion on parliamentary procedure, as a result of which the motion to adopt the General Code as amended was duly withdrawn, and it was decided to act upon the individual amendments to the General Code as recommended in the Final Report of the Committee. It was then moved by Mr. Blickley and seconded by Mr. Rogers that the Committee recommendation for amendment of paragraph G-A.1. of the General Code be. adopted.)

Mr. J. T. Kennedr. Personally, I think that the amendment cuts out something good and puts in something that is none of our business. 
A man has a right to be paid just as truly for his overtime work as for his regular work. The bonus part is just as important as the regular part.

Mr. V. C. KenNedr (Streeter-Amet Co.). I believe there is some misconception of the effect of this amendment, and I wish to recite a specific instance of a serions effect, not on the employee's pay but on the industry as a whole. Let us take the case of unloading ore from a boat, where this ore is weighed. The only reason for the weighing would be to eliminate the possibility of overloading the cars and breaking the bridges. If you do not vote for this amendment it would mean that the entire weighing process would have to be changed, with the probable elimination of all present weighing procedures, because the tolerances would be so tight that weighing equipment such as is now used could not comply. The entire industrial procedure would be slowed down with no resulting good to anybody. The fact of the matter is that a liberal tolerance does not mean that the employee gets any less money. The average results of a scale to which a liberal tolerance is applied are probably just as accurate as the average results of a scale to which a tight tolerance is applied.

Let's take another case where we are dealing with rolls of strip steel. The normal way of determining the amount of that strip steel is to let it roll over a scale and weigh.it in motion. It is undoubtedly adequate for the industrial procedure to have, perhaps, a 1-percent tolerance on that particular operation. If, for any reason, the steel company should add an incentive pay, which is a small addition to a given wage, it would mean, if the proposed amendment is not adopted, that the scale in my example would become a commercial scale with an acceptable tolerance of perhaps one-tenth of 1 percent. The employee would get no more money as incentive pay; his average would come out the same, but the steel company would have to spend a lot of money to change its weighing procedures with no net good for anybody.

The quickest way to defeat the observance of rules is to make them so unpopular and so difficult to follow that they are avoided and honored only in the breach. If you adopt this amendment it simply says that your weighing procedures are no tighter than the industrial processes demand. I believe that is straightforward, honest weighing. The employee makes just as much money, and you do not make the industry spend a lot of money by slowing down their processes to meet an unnecessarily small tolerance. I believe this is serious, gentlemen, and I think it should have your very careful consideration.

(The question was taken and the motion was adopted, thus adopting the Committee amenrment to G-A.1.)

(It was mored by Mr. Blickley and seconded by Mr. Rogers that the amendments recommended by the Committee to $\mathrm{G}-\mathrm{A} .2, \mathrm{G}-\mathrm{A} .3 ., \mathrm{G}-\mathbf{A . 5} ., \mathrm{G}-\mathrm{S} .4 .3 ., \mathrm{G}-\mathrm{S} .4 .5$., and $\mathrm{G}-\mathrm{T} .2$. be adopted.)

Mr. BАбсом. Relative to G-S.4.5., unless there is some means of knowing what the magnification is you are not able to determine your other factors. We require that every scale with a magnifying lens shall be labeled to show the magnifying power of the lens; we usually put that mark just inside the housing. The original paragraph says that it should be ou the outside of the scale. I am not particular about where you put it, but I do think it is important. 
Another thing, the scale mechanic does not know how close to set the indicator wire to the chart unless he knows the magnifying power of the lens. I think it is very important, and I am not in favor of the amendment to G-S.4.5.

(At this point $\mathrm{Ml}^{\circ}$. Blickley agreed to amend the motion to eliminate reference to G-S.4.5. and G-T.2. The question was taken on the motion so amended, and the motion was adopted, thus adopting the Committee's amendments to G-A.2., G-A.3., G-A.5., and G-S.4.3.)

(It was moved hy Mr. Baucom and seconded by Mr. Cranford that the amendment recommended by the Committee to G-S.4.5. be not adopted.)

Mr. Sanders. (National Association of Scale Manufacturers). As we look at this, the proposal for the marking of the magnification of the lens on the scale itself is for the purpose only of providing information to weights and measures departments. As we understand it, this information can be applied only in a laboratory test. There is no manufacturer of computing scales who is not perfectly willing to supply any weights and measures department or any weights and measures official with the information that is needed. We went through this very carefully with the Committee, and I think it was the consensus that there are other ways of providing the information besides marking each individual scale. Under the original language each individual scale would be required to be marked for all time, although the information will be used only very seldom, principally in laboratory tests. Every manufacturer is willing to cooperate in providing the information at any time, and we would like to see this requirement for marking stricken from the code as now proposed by the Committee.

Mr. Crawford. Mr. Sander's, we have a very strong reason for knowing what we are doing when we are inspecting a scale, and if we do not have that information available to our field men, what do you have to offer as a substitute? WVe cannot approach inspection in an intelligent way unless we have just what we are asking for at this time.

Mr. Rogers. In this issue it seems to be a question of inflicting upon the field inspector something that possibly he does not want. Mr. Greene has pointed out that what this deals with is at the approval level; jurisdictions having type approval must put scales through laboratory tests, and it is only in the laboratory that these determinations can be made in a practical way. Inspectors are not going to tear scales down in the field to find out whether or not the magnification agrees with the marked statement.

Information on magnification is always available, and we tell our field men that if they want the information they can get it from us. They can also tell whether a scale is acceptable after we have approved it, because we explain fully any detail that may be questionable when we type-approve a device. I assume that all jurisdictions do the same with their field imspector's. To require magnification would be to inflict on industry a requirement that has no practical purpose in the field. Information relating to magnification must be supplied at the type-approval level where we make our determinations. In view of all this, I think the Committee is wise in now asking for the deletion of the marking requirement.

(The question was taken on the motion to reject the Committee amendment to G-S.4.5. and the motion was lost. It was then moved by Mr. Rogers and seconded by Mr. Christie that the amendment to G-S.4.5., as recommended by the Com- 
mittee be adopted. The question was taken and the motion was agreed to, thus deleting the requirement for the marking of the lens magnification as had originally been proposed.)

(It was moved and seconded that the amendment proposed by the Committee to G-T.2. be adopted, the question was taken, and the motion was agreed to.)

Mr. McBride. The Committee recommends no changes in the code for Linear Measures from the form presented in the 'Tentative Report.

(It was moved by Mr. J. T. Kennedy and seconded by Mr. Witt that the code for Linear Measures be adopted, the question was taken, and the motion wàs agreed to.)

\section{SECTION ON FABRIC-MEASURING DEVICES}

Mr. McBride. The only amendment now proposed to the code for Fabric-Measuring Devices is to eliminate certain language which is unnecessary because the requirement is incorporated in the General Code. [Reading:]

S. 2. In line two, insert a period after the word "graduations" the second time it occurs and strike out the remainder of the paragraph.

(It was mored by Mr. Morgan and seconded by Mr. Christie that the code for Fabric-Measuring Devices, with the amendment proposed by the Committee, be adopted, the question was taken, and the motion was agreed to.)

Mr. McBride. No change is now recommended in the Tentative Code for Cordage-Measuring Devices as presented in the Tentative Report of the Committee. I move that the Tentative Code for Cordage-Measuring Devices be adopted as proposed by the Committee.

(The motion was seconded by Mr. J. T. Kennedy, the question was taken, and the motion was agreed to.)

(Mr. McBride reported that no amendments were being proposed to the codes for Taximeters, Odometers, and Liquid Measures, from the form in which these appeared in the Tentative Report of the Committee. He mored, successively, that these codes be adopted, each motion was duly seconded, and each motion was duly adopted.)

\section{SECTION ON GRADUATES}

Mr. McBride. The amendment now proposed to S.4.3. of the code for Graduates is to correct a typographical error. [Reading:]

\section{S.4.3. Change "S.4.3." to "S.4.2."}

(It was moved by Mr. McBride and seconded by Mr. Blickley that the code on Graduates be adopted with the amendment proposed by the Committee, the question was taken, and the motion was agreed to.)

(Mr. McBride reported that no amendments were being proposed to the codes for Measure Containers and Milk Bottles, from the form in which these appeared in the Tentative Report of the Committee. He moved, successively, that these codes be adopted, each motion was duly seconded, and each motion was duly adopted.)

\section{SECTION ON LUBRICATING-OIL BOTTLES}

Mr. MCBride. One amendment is now proposed to the code for Lubricating-Oil Bottles, to restore a requirement which was formerly in effect but which was deleted during the war because of the difficulty of obtaining uncolored glass. The proposed amendment is as follows:

Insert a new paragraph to be numbered S.2. and to read as follows:

S.2. Material.-Bottles shall be made of clear, uncolored glass.

Renumber the remaining " $\mathrm{S}$ " paragraphs.

(It was moved by Mr. McBride and seconded by Mr. Fuller that the code for Lubricating-Oil Bottles be adopted with the amendment proposed by the Committee, the question was taken, and the motion was agreed to.) 


\section{SECTION ON LIQUID-MEASURING DEVICES}

Mr. McBride. After due consideration and a hearing with representatives of equipment manufacturers and industry, the Committee now proposes several amendments to the code on Liquid-Measuring Devices as presented in the Committee's Tentative Report. The first of these proposed amendments relates to N.1.1. It is proposed to establish two types of tests for" liquid-measuring devices, "normal" tests and "special" tests. "This distinction becomes important in relation to the changes which will be proposed in the tolerances for liquid-measuring devices, whereby different tolerances will be set up for the "normal" and for the "special" tests.

A "normal" test is simply defined as a test at the maximum discharge rate that the installation will develop. "Special" tests are not defined in detail except that such tests shall include tests at specified minimum discharge rates. Other details of special tests are left to the judgment of the official. The proposed amendment is as follows:

\section{N.1.1. Amend this paragraph to read as follows:}

The "nolmal" test of a commercially installed meter or meter-type device shall be made at the maximum discharge rate developed under the conditions of installation. "Special" tests, to develop the operating characteristics of meters and meter-type devices, shall be made as circumstances require; a retail device shall be so tested at a mininum discharge rate of 5 gallons per minute; a wholesale device shall be so tested at a minimum discharge rate of (a) 15 gallons per minute for a device smaller than 2 inches in rated size, (b) 20 percent of the marked maximum rate for a device 2 inches or over in rated size, or (c) at any lower minimum rate marked on the device.

(It was moved by Mr. A. T. Smith and seconded by Mr. Rogers that the amendment proposed by the Committee to N.1.1. be adopted.)

Mr. Crockett. The proposed language covering the "special" test is very vague. There is no use in our adopting something which will not be put into effect when we go back to our own jurisdictions. I wish to record my vote as opposed to this amendment.

(The question was taken, and the motion was agreed to, thus adopting the Committee's amendment to N.1.1.)

Mr. McBride. It is proposed to amend N.1.2. by rephrasing it to emphasize more strongly the need for adequate testing equipment. The amendment proposed is as follows:

N.1.2. Change the second sentence of the paragraph to read as follows:

For wholesale devices, testing drafts should be equal to at least the amount delivered by the device in 1 minute at its maximum discharge rate, and shall iu no case be less than 50 gallons.

(It was moved by Mr. Baucom and seconded by Mr. Becker that the proposed smendment be adopted.)

Mr. Crocketr. Tre must test all types of meter's. Can you honestly say that a meter can be adequately tested with a 50-gallon draft?

Mr. McBride. We say that the draft should take full flow for 1 minute, and that 50 gallons is the smallest draft that shall be used. We have tried to consider all localities, some of which may not need test measures of more than 50 gallons and some of which may not be able to obtain test measures with capacities above 50 gallons. Fifty gallons is specified as a minimum, but tests are not restricted to that amount. 
Mr. Crocketr. If any jurisdiction does not liave adequate equipment to test these meter's, it is up to them to get it, and we should not write the specifications to fit the equipment of such jurisdictions.

Mr. A. T. Sмrth. It is up to us to obtain proper equipment. There are a number of jurisdictions in New Jersey with 50-gallon measures, and you cannot actually test a 300-gallon-per-minute meter with a 50 -gallon measure. The various jurisdictions in the country should obtain adequate means for testing these meters as soon as possible.

(The question was taken and the motion was agreed to, thus adopting the ameudment to N.1.2. as proposed by the Committee.)

Mr. McBride. The next amendment proposed by the Committee relates to P.1. The amendment consists essentially of the deletion of the requirement that errors of underregistration shall be disregarded when the device is operated considerably faster or slower than normal speed of operation; that requirement was in the old specification back in the days of hand-operated pumps when variable speeds were possible. The recommendation is as follows:

P.1. Amend this paragraph to read as follows:

The deliveries of a device shall be accurate (a) irrespective of whether operation is continuous or intermittent, (b) irrespective of the speed of operation, subject, however, to the provisions of T.1., and (c) irlespective of the time elapsing between operations, subject, howerer, to the provisions of T.2.

(It was moved by Mr. Becker and seconded by $M \mathrm{r}$. Peikert that the amendment proposed by the Committee to paragraph P.1. be adopted, the question was taken, and the motion was agreed to.)

Mr. McBride (reading) :

T.1. Amend the side title and the first sentence of this paragraph to read as follows :

On "Normal" Tests And "Special" Tests Except Elapsed-Time Tests.Maintenance tolerances on underregistration or on overrcgistration shall be as slown in Table 1 ; acceptance tolerances for retail devices and on "normal" tests of wholesale devices shall be one-half the maintenance tolerances; acceptance tolerances on "special" tests of wholesale devices shall be the same as the maintenance tolerances on such tests. (See N.1.1.)

In table 1 , amend the tolerances for wholesale devices to read as follows:

For wholcsale devices

\begin{tabular}{c|c|c}
\hline \multirow{2}{*}{$\begin{array}{c}\text { Indication of } \\
\text { device }\end{array}$} & \multicolumn{2}{|c}{ Tolcrance } \\
\cline { 2 - 3 } Gallons & On "normal" tests & \multicolumn{2}{|c}{ On "special" tests } \\
\hline $50 \ldots$ Cubic inches & \multicolumn{1}{|c}{ Cubic inches } \\
\hline $\begin{array}{l}50 \ldots \\
\text { Add } 1 / 2 \text { cubic inch per indicated } \\
\text { gallon. }\end{array}$ & $\begin{array}{l}50 \\
\text { Add 1 cubic inch per indicated } \\
\text { gallon. }\end{array}$ \\
\hline
\end{tabular}

Mr. MCBnide. This amendment, gentlemen, is one on which much time and effort have been expended. In the Tentative Report we proposed a 50-percent reduction of the tolerances for wholesale devices to be effective July 1, 1950. After much consideration the Committee now proposes an immediate reduction of the tolerances on "normal" 
tests of wholesale devices, and a continnance of the old tolerances of 1 cubic inch per indicated gallon for "special" tests of these devices. It is further proposed that acceptance tolerances be one-half the maintenance tolerances on "normal" tests and that the acceptance tolerances on "special" tests be the same as the maintenance tolerances.

In considering the whole problem of tolerance, an important factor is the adequacy of testing equipment. In some States more progress has been made than in others in obtaining adequate equipment, but the Committee doubts that it would be justified on that account in going beyond its present recommendation in setting up the degree of accuracy for commercial equipment which it asks officials to enforce. We do not feel that we should ask an official to do more along this line than we feel he is able to do. The condemnation of devices is a serious matter and may readily be challenged, and the official must be in a position to smpport his action of condemnation. That is the basic reason for the amendment which the Committee now recommends.

Mr. Baucon. This is the only thing in the entire code on which I wish to ask your serious consideration; it would not affect my State because for a number of years we have been operating on a tolerance of 0.1 percent across the board. However, I am willing to go along on this entire set-up if you will just change three words. Wherever the expression "the tolerance shall be" occurs, change it to read "the tolerance shall not exceed." That will give you the opportunity of reducing the tolerance if your equipment and conditions justify that action.

I do not think that we should be bound to a specific tolerance regardless of all modifying conditions, and I do not believe any of you want to have a regulation telling you that you must allow a certain tolerance regardless of all conditions. In all of our early books the expression "shall not exceed" was used, but when the expression "shall be" is used, that just nails you right down to specific values. I think that if you would take legal advice, you would find that this definitely legalizes short measure because you must allow that amount and the error would be that which is in excess of the tolerance. The changes I propose would leave you free to judge the matter according to the circumstances and conditions involved. I move this change be made in all of the codes.

(The motion was seconded by Mr. Jensen.)

The Secretari. I should like to suggest to the Conference that the language proposed by Mr. Baucom does not fix the tolerance at all. It merely fixes a limit to the tolerance. TVhen the National Conference adopts a code including tolerances, that action constitutes a recommendation to the States. The tolerances have no force and effect anywhere unless they are given force and effect by competent authority in and for some particular jurisdiction. If a particular jurisdiction feels that a tolerance which the Conference has recommended is too great, it is competent for it to change the tolerance to whatever value it desires, subject, of course, to such review by the conrts as might be invoked. If the Conference says that a tolerance "shall not exceed" a certain value, this merely places an upper limit on the tolerance value, and it is still necessary for the State to decide what the tolerance "shall be." When the Conference says that a tol- 
erance "shall be" a certain value, then its recommendation to the States is definite. A tolerance is an expression of the limit of permissible error. When we say that the tolerance "shall be" a certain amount it means that a device should be approved if its error does not exceed the stated tolerance. Years ago we used in our codes the expression "shall not exceed"; after due consideration that was changed, and all of our codes were reworded to say that the tolerance "shall be" a specific value.

The Committee feels that it is proper to give the weights and measures departments of the country specific tolerance values. Those departments have the option to change the tolerance values if they see fit, but I think that it would be ill-advised for the Conference to be indefinite in its recommendations, thus leaving the matter open for action by the States', which would not be uniform.

Mr. BAuconr. My definition of tolerance is the difference between perfection and prosecution, and it is the range in which an inspector can use his own discretion. If the change which $X$ propose is not made, what you are doing here is passing laws which the fellows out yonder liave to live by. In my State, happily, I do not have to take it. I ask that we make this thing flexible enough for us to live by, but I want to set a ceiling on it, because when it goes beyond that point we should take it into court. My proposal leaves it within the discretion of the inspector.

The Secretary. What Mr. Baucom has proposed, as I see it, would produce an intolerable situation. If every inspector of weights and measures can use his discretion to any extent desired, we would have inspectors who would recognize no tolerances at all, and that certainly is an intolerable situation. It is impossible for all devices to be perfect. Errors are to be expected. The tolerance is supposed to be fixed after due consideration and represent the permissible limit of error within which a device will be approved.

If Mr. Baucom wants his inspectors to be able to vary the tolerance according to the situation which exists in a particular instance, that, of course, is a matter for administrative decision on his part. But I think that would be contrary to the fundamental concept upon which all of our codes are based-our whole theory of tolerances. The tolerance is supposed to be so small that error's within the tolerance will not seriously hurt anybody. The tolerance so fixed should be observed by the inspector. If the tolerance is too large it can be reduced. But it should be fixed, and when so fixed it should be observed.

Mr. J. T. Kennedr. I believe that "shall be" is a little tight. Why can't we use the word "maximum"? I think that would satisfy everybody.

Mr. R. E. Menk. Indiana is one of those States that has always been proud to put into eflect the actions of this Conference. We adopted, by reference, Handbook H29. We anticipate adopting, by reference, these new codes. Due to the wording of the Indiana law we find it absolutely necessary to adopt these codes by reference, and it is not possible for us to tear into them and rewrite them; and not only that. but we do not want to take such action. It is absolutely necessary that definite tolerances be established, and for that reason I am ver'y much opposed to $\mathrm{Mr}$. Baucom's motion.

$858144-50 \longrightarrow 12$ 
Mr. V. C. Kennedy. Gentlemen, you must remember that these machines have to be built. If we do not know what the tolerance is, we camnot build them. If the manufacturer has no idea what the tolerance is going to be, it is just a case of "no soap." Your Committee has given very careful consideration to its wording. Any manufacturer knows what this wording neans, and when Mr. Smith says that under the proposed amendment you would have an intolerable situation, he is just 100 percent correct. If the manufacturer does not know how to build his machine except that he must satisfy all of the weights and measures people, he might just as well go out of business.

(The question was taken on the motion to substitute the words "shall not exceed" for the words "shall be" in all tolerance statements in all of the codes, and the motion was lost.)

(It was moved by Mr. C. M. Fuller and seconded by Mr. Nelson that the amendment to 'T. 1 . of the code for Liquid-Measuring Devices be adopted.)

Mr. Crockert. With respect to the proposed tolerances for wholesale devices, I do not think we should go on record as approving devices that are faulty and that cannot and will not give correct measure. Under these tolerances, on a 5000-gallon delivery there could be an error of 5000 cubic inches. Why should we go on record as asking a man to accept short measure of that amount. The tolerance is too great. In plain words it leagalizes stealing.

Mr. C. M. Fuluer. I do not think that there is any section of the country which has to do more meter testing under all conditions than the West Coast, which is the heart of the petroleum industry. I am just as strong for close tolerances as anybody, but I also have adequate equipment for testing at all rates of flow and under all conditions. Based on tests of hundreds of these devices I must say that we need tolerances that are enforceable and that do meet actual conditions. It is one thing to have a meter on a test line and just test the accuracy of that meter by itself; but it is another thing to test as we must test it under conditions of actual installation with all of the different equipment that goes to make that installation. For that reason, and for the fact that we must work under tolerances that are enforceable, I support the adoption of these tolerances.

(The question was taken on the motion to adopt the Committee amendment to T. 1, including the aumendment to table 1 , and the motion was agreed to.)

(It was moved by MIr. McBride and seconded by Mr. R. E. Meek that the code on Grease-Measuring Devices, as presented in the Tentative Report, be adopted, the question was taken, and the motion was agreed to.)

\section{SECTION ON VEHICLE TANKS}

Mr. McBride. In preparing the revision of the code on Vehicle 'Tanks, certain language previously in effect was inadvertently omitted in the Tentative Report. This omission is corrected by the following recommendation. [Reading:]

Add a new paragraph to be numbered S. 10.6., and to read as follows:

S. 10.6. COMPLETENess of DeLIVERY.-When a rehicle tank is standing upon a level surface, complete delivery shall he made from any compartment through its delivery faucet or valve whether other compartments are full or empty.

(It was moved by Mr. J. T. Kennedy and seconded by Mr. R. E. Meek that the Committee recommendation be adopted, the question was taken, and the motion was agreed to.) 
Mr. McBride. The next recommendation of the Committee is made to clarify the requirement relative to the positioning of a meter to insure readability of its indications. The Committee recommendation is as follows:

\section{S. 21.1. Amend this paragraph to read as follows:}

The indicating elements of a meter shall be so positioned that their indications may be easily and accurately read, and except as provided in S. 21.2., a meter shall conform to all applicable specification requirements for wholesaletype devices given in the code for Liquid-Measuring Devices.

(It was moved by Mr. J. T. Kennedy and seconded by Mr. Rogers that the Committee recommendation be adopted, the question was taken, and the motion was agreed to.)

Mr. McBrios. It has been pointed out to the Committee that in some areas and under some circumstances it may be difficult to obtain water to be used as a testing medium for vehicle-tank compartments. The Committee is of the opinion that light fuel oil is suitable for this purpose and that it should be specified as an alternative testing medium. Accordingly, the Committee makes the following recommendation :

N. 1.1. In line one, after the word "Water", add the words, "or light fuel oil".

(It was mored by Mr. J. T. Kennedy and seconded by Mr. Becker that the recommendation of the Committee be adopted, the question was taken, and the motion was agreed to.)

Mr. McBride. The Committee proposes an amendment of N. 2.1. relative to discharge rates for meter's to conform to the corresponding requirement, in the code on Liquid-Measuring Devices which you have already adopted. "Normal" and "special" tests are proposed to be set up for meters and the operating elements associated with meters installed on vehicle tanks. The recommended anendment is as follows:

N. 2.1. Amend this paragraph to read as follows:

The "normal" test of a meter shall be made at the maximum rate permitted by the installation. "Special" tests, to develop the operating characteristics of a meter and the operating elements associated therewith, shall be made as circumstances require; a meter smaller than 2 inches in rated size shall be so tested at a minimum discharge rate of 15 gallons per minute, and a meter 2 inches and over in rated size shall be so tested at a minimum discharge rate of 20 percent of the marked maximum rate, or the test shall be made at any lower minimum rate marked on the meter.

(It was moved by Mr. Booth and seconded by Mr. Nelson that the amendment recommended by the Committee be adopted, the question was taken, and the motion was agreed to.)

Mr. McBride. The Committee recommends the amendment of N. 2.2., to make the language conform to corresponding language in the code for Liquid-Measuring Devices, which has already been adopted, as follows:

N.2.2. Amend this paragraph to read as follows:

Testing drafts should be equal to at least the amount delivered by the meter in one minute at its maximum discharge rate, and shall in no case be less than 50 gallons.

(It was moved by Mr. A. T. Smith and seconded by Mr. Becker that the amendment recommended by the Committee be adopted, the question was taken, and the motion was agreed to.) 
Mr. McBride. The amendment proposed by the Committee to P.1. will make this conform to the amendment already adopted to N.2.1., and is as follows:

P.1. Amend this paragraph to read as follows:

The delivery of a meter shall be accurate (a) irrespective of whether its operation is continuous or intermittent, and (b) when operated as specified in N.2.1, subject, however, to the provisions of T.2.1.

(It was moved by Mr. R. E. Meek and seconded by Mr. F. C. Yarbrough that the amendment proposed by the Committee be adopted, the question was taken, and the motion was agreed to.)

Mr. McBride. The Committee recommends the amendment of T.2.1. and of table 2 to conform to the corresponding requirements of the code on Liquid-Measuring Devices which have already been adopted. The proposed amendment is as follows:

T.2.1. Amend this paragraph to l'ead as follows:

Maintenance tolerances, on under-registration or on over-registration, shall be as shown in Table 2 ; acceptance tolerances on "normal" tests shall be one-half the maintenance tolerances; acceptance tolerances on "special" tests shall be the same as the maintenance tolerances on such tests. (See N.2.1.)

Amend Table 2 to read as follows:

Table 2.-Maintenance Tolerances for Vehicle-Tank Meters

\begin{tabular}{|c|c|c|}
\hline \multirow{2}{*}{$\begin{array}{l}\text { Indication of } \\
\text { meter }\end{array}$} & \multicolumn{2}{|c|}{ Tolerance } \\
\hline & On "normal" tests & On "special" tests \\
\hline $\begin{array}{c}\text { Gallons } \\
50 \ldots \\
\text { Over } 50 \ldots\end{array}$ & $\begin{array}{l}\text { Cubic inches } \\
50 \\
\text { Add } 1 / 2 \text { cubic inch per indicated } \\
\text { gallon. }\end{array}$ & $\begin{array}{l}\text { Cubic inches } \\
50 \\
\text { Add } 1 \text { cubic inch per indicated } \\
\text { gallon. }\end{array}$ \\
\hline
\end{tabular}

(It was moved by Mr. Fraser and seconded by Mr. Becker that the amendment proposed by the Committee be adopted, the question was taken, and the motion was agreed to.)

Mr. McBride. Having established the category of "special" tests, the Committee recommends deletion of the material in the Tentative Report relative to "multiple compartment" tests, as follows:

\section{T.2.2. Strike out the entire paragraph.}

(It was moved by Mr. A. T. Smith and seconded by Mr. Nelson that the recommendation proposed by the Committee be adopted, the question was taken, and the motion was adopted.)

(It was moved by Mr. McBride and seconded by Mr. Morgan that the code for Dry Measures as prescribed in the Tentative Report be adopted, the question was taken, and the motion was agreed to.)

\section{SECTION ON BERRY BASKETS AND BOXES}

Mr. McBride. The Committee is of the opinion that the same tolerances should apply whether the berry baskets and boxes are made of wood, pasteboard, or fiber. Accordingly, the following amendments are recommended:

A.1. In line two, insert a period after the word "less", and strike out the remainder of the paragraph. 
T.1. Amend Table 1 to read as follows :

Table 1.-Acceptance Tolerances for Berry Baskets and Boxes

\begin{tabular}{l|c|c}
\hline \multirow{2}{*}{ Capacity of basket or box } & \multicolumn{2}{|c}{ Tolerance } \\
\cline { 2 - 3 } & In excess & In deficiency \\
\cline { 2 - 3 } & & \\
\hline $1 / 2$ pint & Cubic inches & $\begin{array}{c}\text { Cubic inches } \\
0.5 \\
1 \text { pint }\end{array}$ \\
& 2 & 1.0 \\
& 3 & 1.5 \\
\hline
\end{tabular}

(It was moved by Mr. A. T. Smith and seconded by Mr. Rogers that the amendments proposed by the Committee be adopted, the question was taken, and the motion was agreed to.)

\section{SECTION ON SCALES}

Mr. McBride. The first three recommendations of the Committee are for the purpose of supplying side titles, and are as follows:

A.1. Insert the side title, "Gereral.--"

A.2. Insert the side title, "Precious-Metals Scales.-"

A.3. Insert the side title, "Commercial Person Weighers._"

(It was moved by Mr. Blickley and seconded by Mr. Nelson that the recommendations of the Committee to A.1., A.2., and A.3. be adopted, the question was taken, and the motion was agreed to.)

Mr. McBride. The next recommendation of the Committee is to supply an inadrertent omission from the Tentative Report, and is as follows:

Add a new paragraph to be numbered A.4., and to read as follows:

A.4. Moisture-Test Scales.-The requirements for cream-test scates shall apply, insofar as they ale applicable, to moisture-test scales, except that prescribed test loads shall be 10 grams instead of 18 grams.

(It was moved by Mr. A. T. Smith and seconded by Mr. Fraser that the recommendation of the Committee be adopted, the question was taken, and the motion was agreed to.)

Mr. McBride. The next recommendation of the Committee is to provide a needed exception in the definition of SR for a scale with a trig loop but without a balance indicator, to meet a special condition which is covered by an amendment to be proposed to N.1.5., as follows :

D.5.2. Change the final period to a comma and add the rords, "except as is provided in N.1.5."

(It was moved by Mr. Morgan and seconded by Mr. Blickley that the reconmendation of the Committee relative to D.5.2. be adopted, the question was taken, and the motion was agreed to.)

Mr. McBride. Paragraph S.5., as presented in the Tentative Report, was intended to refer particularly to computing scales, and the Committee believes that the paragraph should be transferred to the computing-scale section of the code. The Committee also proposes the inclusion of additional language to control the manually-operable means for tare adjustment; it is proposed that such adjustment be so limited that the balance of the scale could not manually be set in advance of the zero position established by the mechanically-controlled 
balancing device on the seale. The recommendation of the Committee is as follows:

S. 5. Renumber this paraglaph to become "S. 23." and amend it to read as: follows :

S. 23. Pre-Packaging Scale.-A computing scale designed to be used exchsively for putting up packages in advance of sale, and conspicuously marked on the operator's sicle and on the opposite side with the worls "For Pre-Packaging Use Only" or with a similal and suitable statement, shall be exempt from the requirements of paragraph S. 21. and, if "customer's' weight indications" are not provided, from the requirements of paraglaph S. 22. which relate to customers' weight indications; and such a pre-packaging scale may be equipped with an auxiliary, manualy-operable balancing device if this is so designed that it will operate only in a backwarl direction (that is, in the direction of under-registration) with respect to the balance condition established by the primary, luechanically-operable balancing device of the scale.

(It was moved by Mr. Becker and seconded by Mr. A. T. Smith that the recommendation of the Committce be adopted, the question was taken, and the motion was agreed to.)

Mr. McBride. The addition proposed to S. 20 . by the next recommendation of the Committee is to correct an inadvertent omission from the Tentative Report of language which has previously been in effect. The recommendation is as follows:

S. 20. Add at the end of this paragraph the following:

Value figures and graduations shall not be duplicated in any column or row on a chart.

(It was moved by Mr. Morgan and seconded by Mr. R. E. Meek that the recommendation of the committee be adopted, the question was taken, and the motion was agreed to.)

Mr. McBride. The next recommendation relates to N. 1. 5. and covers the situation, previously referred to in the discussion of the amendment to D. 5. 2., where special scales are designed for use with weighbeams and with automatic-indicating or automatic-recording elements necessitating weighbeam travel greater than normal. The situation is a rather special one, but the Committee feels it should be recognized, and accordingly makes the following recommendation:

N. 1.5. Change the final period to a comma and add the following:

and if such seale is one in which the weighbcam travel is in excess of that required by $\mathrm{S}$. 2.3.2., the SR determination shall be based upon the weighbeam. travel required by S. 2.3.2.

(It was moved by Mr. Blickley and seconded by Mr. Christie that the recommendation to N.1.5. be adopted, the question was taken, and the motion was agreed to.)

Mr. McBride. In T.1.1.2. the Committee recommends the change of a figure to correct a typographical error and the addition of language setting up the tolerance on shift tests for prescription and cream-test scales. The recommendation is as follows:

T.1.1.2. In line six, change the figure " 5 " to "6", change the period to a comma, and add the following:

except that on a prescription scale or cream-test scale, twice the appropriate basic tolerance shall be applied.

(It was moved by Mr. Becker and seconded by Mr. Morgan that the recommendation of the committee be adopted, the question was taken, and the motion was agreed to.) 
Mr. McBride. The final recommendation of the Committee is designed to amend a table heading, and is as follows:

T.1.2.1. Amend the heading of Table 5 to read as follows :

Minimum Tolerance Values for Small-Capacity Non-Automatic-Indicating Scales Not Equipped with Weighbeams.

(It was moved by Mr. Becker and seconded by Mr. Nelson that the recommendation of the Committee be adopted, the question was takcn, and the motion was agreed to.)

Mr. Blickley. I should like to refer to scale regulation R. 5., Uncompensated Spring Scales. This is a good requirement but it is not workable in its present form. It becomes our duty, after the scales are sold, to confiscate many of them because the people who buy them are not aware of the limitation on their use. 'To avoid that umpleasant duty I move that there be added at the end of this regulation the words, "Scales shall be conspicuously marked with the words, 'illegal for" commercial use except for fruits and vegetables, or with a similar $\mathrm{Ol}^{*}$ suitable statement."

Mr. Brenton. That language would confine the use of an uncompensated spring scale to the sale of fruits and vegetables. I believe that is going too far. In California we use a ticket stating that if the scale is used in the retail sale of foodstuffs, its use must be confined to fruits and vegetables.

Mr. Sanders. Could not the required marking be confined to something like "Retail" or "Fruits and Vegetables?" What you suggest is very long.

Mr. Buicklex. Any suitable statement would be satisfactory.

The Secretary. Is it the sense of your proposed amendment that an uncompensated spring scale shall be so marked as to indicate that within the category of foodstuffs it may only be used for weighing fruits and vegetables but that it may be used for other purposes-that is, for the weighing of commodities other than foodstuffs?

Mr. Buickley. Yes; that is agreeable.

The Secretary. Then, if the Conference approves your motion, may I suggest that, for purposes of clarity of lauguage, the phrasing be left to the Committee on Specifications and Tolerances?

Mr. Buickler. That will suit me.

(The motion was seconded by Mr. Becker.)

Mr. Felgoise (Pem Scale Co.). I appreciate the purpose of the motion that was made by Mr. Blickley and I am in full accord with it. However, we, and I believe other manufacturers, have on hand a quantity of dials that have already been processed, and we would appreciate a time limit on this new requirement. If the requirement were to be made effective immediately, we would have to discard all of the dials that are already processed. We would appreciate a delay in the effective date of 6 months or a year.

Mr. Buicklex. I will add to the motion that the requirement become effective January 1, 1950. That is 7 mouths from now. Moreover, the marking can be put on the dial with a decalcomania or rubber stamp.

(The question was taken and the motion was agreed to, thus directing the Committee on Specifications and Tolerances to incorporate in the Scale Code the requirement covered by $M_{1}$. Blickley's motion.) 
(SEcretars's Note.-At a meeting of the Committee on Specifications and Tolerances, held immediately following adjournment of the National Conference and attended by Mr. Blickley, it was agreed to incorporate the requirement expressed by Mr. Blickley's motion as an addition at the end of 5 . 4. of the Scale Code. This addition is as follows: Effective January 1, 1950, a small-capacity uncompensated spring scale other than a straight-face spring scale shall be conspicuousty marked to show that the scale is illegal for use in the retail sale of foodstuffs other than fruits and vegetables.)

(It was mored by Mr. McBride and seconded by Ml. Blickley that the Code on Weights as presented in the Tentative Report of the Committee be adopted, the question was taken, and the motion was agreed to.)

Mr. McBride. We have given you a Tentative Report and a Final Report, the latter amending the former in a number of places. All of the amendments have been specifically adopted. I now move that all of the codes, as offered in the Tentative Report and as amended, be adopted by the Conference.

(The motion was seconded by Mr. Blickley.)

Mr. BAucom. I propose an amendment to the effect that the Committee or the Conference Secretary be authorized to correct any grammatical or other errors, smoothing the whole thing out so that we will have a correct final document.

(The amendment was accepted by Mr. McBride and Mr. Blickley, the question was taken, and the motion was agreed to.)

(SEcreTarx's Note.--Under the authority of the preceding motion the Secretary has made a number of minor changes, to correct typographical errors previously overlooked, to supply a few missing paragraph side-titles, to make the language and punctuation uniform throughout, and, in general, to carry out the intent of the motion. It is considered unnecessary to report all of such changes herein, since NBS Handbook H4t, which will carry all of them, will be available before this Report is issued.)

Mr. Errckson (National Association of Scale Manufacturers). I have a short statement which I should like to read into the record.

On behalf of the National Association of Scale Manufacturers I would like at this time to express our appreciation of the fine spirit of cooperation with our industry exhibited by Dr. Condon, Messr's. Smith, Bussey, McBride, and the member's of the Specifications and Tolerances Committee. I have particular reference to the consideration given by the Committee to the suggestions presented by the scale manufacturing industry regarding the changes in the new Handbook. I know that I speak for Mr. Kennedy who heads up our Technical Committee, when I say it is our hope that the future will bring an even closer cooperation between the two groups. In the relatively short period of time since the formation of the National Association of Scale Manufacturers I feel that we have progressed a long way toward this end.

Mr. Nelson. If it is in order I would like to suggest that serious consideration be given next year to starting the Conference on Monday rather than on Tuesday, to avoid winding up, as we are today, late in the afternoon when it is going to be difficult to get home before the week end. 
The Criamman. I think that is something for the Executive Committee to take into consideration next year.

\section{ADJUSTMENTS BY WEIGHTS AND MEASURES OFFICIALS}

Br C. H. OAKLer, Inspector of Weights and Measures, State of
Wyoming

This topic has been discussed among weights and measures officials for a great number of years, and I do not believe a definite answer can be given which will be the solution to the problem in every jurisdiction, simply because how far an official should go in making adjustments on weighing and measuring devices depends on so many factors.

It niay be well at this point to bring out this fact: 'The main funetion of weights and measures work is chiefly in a regulatory capacity, and we do not have the authority to go into the field of repair.

Since it is the official's duty to be of service to the public, the question of how far he should go in making adjustments on weighing and measuring devices will be ever-present. If it is elected to adopt a program of doing extensive adjustments, several problems will have to be taken into consideration. It is granted the official will be doing the owner of the device a favor, but what of the repairmen who make their livelihood from this work? The repairman is as much a part of the public as the owner of the device, and we would certainly be doing him an injustice if we adopted the policy of doing extensive adjustments. A policy of this nature would tend to discourage interest in service work, and it is not only necessary, but essential, that we encourage interest and activity in service work. It is a known fact that the most workable arrangement among people is on a cooperative basis. So I feel it is essential that we have the voluntary cooperation of our service mechanics.

Now let us consider the inspecting official, for certainly he is an important link in the chain. Surely an inexperienced official is making a grave mistake by attempting to make any adjustment with which he is not familiar. Actions such as this should be prevented, for they only invite unfavorable criticism not only to the official, but to the whole Weights and Measures Division. So to a great extent, what adjustments are made will depend on the knowledge of the inspector. Of course, there are some adjustments which I feel every inspector should know how to make, and some which I feel an inspector should not make, regardless of whether he knows how or not. 'These I will mention later on in the discussion.

The a vailability of service is another important factor, for it will tend to influence the decisions of the inspector. In some parts of the United States this subject does not constitute a problem, but in the majority of the States I believe it does. If service is available immediately, the inspector probably will do very little adjusting; on the other hand, if service is not available within a reasonable length of time, the inspector would be justified in making certain adjustments. First, however, he should have the definite consent of the owner, and should clearly establish his position as that of being willing. without charge to the owner, to undertake the work in question, without implying any guarantee of accomplishing the desired results. At times this will save the inspector a return visit to the establishment, 
and will avoid unjustifiable expense or inconvenience to the owner. I do not advocate, however, that the inspector should go into the general field of repair-for instance, the grinding of pivots on largecapacity scales, or any other major repair work. Work of this nature should be done by a competent repairman or service shop.

It will depend to a great extent on the policy adopted by the Weights and Measures Division, and the inspector's knowledge and experience, as to how far he is to go in making adjustments. But, in general, there are some adjustments which I feel the inspecting official should make. Computing scales: I feel the official should level the scale, adjust the zero balance, adjust oscillation, and at times put oil in the dash pot. 'These adjustments take only a few minutes of the official's time, but they do lender a service to the owner of the device. I have found that a large percentage of scale owners are ignorant of the function of the dash pot, and do not know how to adjust the oscillation ment; the scale should be condemned, and a competent scale mechanic of the indicator. If after performing the above operations the scale is still in error, he should in no case attempt to adjust the pendulum, chart weights, cams, nose irons, springs, or any other adjustable elecontacted.

Large-capacity scales: I feel that an inspector should first make a. pit inspection. He should check for worn or broken pivots, check the lever's for plimb and level, and for the cleanliness of the pit, ete. An inspection of the pit will usually save the inspector time. The beam should be balanced before he starts his test procedure. If the scale is found upon test to be in error, and the error is such that a nose-iron adjustment will remedy it, I can see no objection in making the adjust. ment, of course with the consent of the owner. I feel an inspector should make no other adjustments on a large-capacity scale.

Retail and wholesale gasoline pumps: Unless the official has had considerable training, he should make no adjustments whatsoever. However, if the official has had sufficient training to be sure the error in gasoline pumps can be corrected by a simple morement of the adjusting element, and it is agreeable with the owner of the pump. I can see no objection to his making this adjustment. The official should proceed with caution, and know just what he is doing if he attempts to adjust meters.

Vehicle-tank compartments: I feel that if the tank is in good shape, no dents, etc., the markers in these tanks should be adjusted when found to be incorrect.

Gentlemen, this talk has not been a lengthy one, although the subject matter is in that category where discussion could go on and on. A person could go into detail about the unhappy situations in which an official finds himself because of making certain adjustments. There is no doubt that the official has to make wise decisions on this matter quite often. Over a year ago I found myself in one of these mnhappy situations in my State. I had adjusted the meter on a retail gasoline pump, first getting permission of the owner. About three weeks later the owner of the pump started calling the office complaining that I had set the pump long. I happened to be out in the field at the time, and could not make a special trip back to the town. The story finally reached the Governor, and consequently I received a letter stating that. in the future I was not to adjust any more meters. When I arrived 
back at that particular town, I learned that the error had been caused by a bad computor head, and not by the metering device at all. The computor head had gone bad after the meter had been adjusted, so it was quite natural for the owner to think that I lad adjusted the pump wrong. After all the facts were known, the owner of the pump extended me his apology, so everything turned out all right in the end. A IVeights and Measures Division will receive some criticism, even though at times it is not justified. Yet, in my State we still adjust meters, when we are positive that the error can be remedied by such an adjustment.

In closing, I would like to make this statement: I do not believe that, there is only one solution to this problem. The policy followed with success in one State may not solve the problem in another State.

\section{REPORT OF THE NATIONAL CONFERENCE COMMITTEE ON RESOLU-} TIONS, PRESENTED BY J. E. BRENTON, CHAIRMAN

\section{APPRECIATION TO DIRECTOR AND STAFE OF THE NATIONAL BUREAU OF STANDARDS}

Whereas, Dr. E. U. Condon, R. W. Smith, W. S. Bussey, and their able and efficient staff have extended valuable assistance and guidance to this Conference, of which the Conference is sincerely appreciative: Therefore be it

Resolved, That this, the 34th National Conference on Weights and Measures, does hereby record its grateful appreciation to the abovenamed gentlemen.

\section{IN MEMORY OF DECEASED MEMBERS}

Whereas, we the delegates of the Thirty-Fourth National Conference on Weights and Measures have learned with regiet of the death of Mr. Joseph Giuliamo, one of our esteemed associates; and

Whereas, his passing will leave a serious gap in the ranks of weights and measures activities; Therefore be it

Resolved, That we the delegates and guests to the 34th National Conference on Weights and Measures do hereby express our deep sorrow and sympathetic condolence for the bereaved family and for the community of which he was such an outstanding part.

Whereas, we the delegates of the $34 t$ th National Conference on Weights and Measures have learned with regret of the deatl of Mr. Wesley Vaughn, one of our esteemed associates; and

Whereas, his passing will leave a serious gap in the ranks of weights and measures officials; Therefore be it

Resolved, That we the delegates and guests to the 34th National Conference on Weights and Measures do hereby express our deep sorrow and sympathetic condolence for the bereaved family and for the community of which he was such an outstanding part.

Whereas, we the delegates of the 34th National Conference on Weights and Measures liave learned with regret of the death of $\mathrm{Mr}$. George E. Cliatillon, one of our esteemed associates; and

Whereas, his passing will leave a serious gap in the ranks of weights and measures activities; Therefore be it 
Resolved, That we the delegates and guests to the 34th National Conference on Weights and Measures do hereby express our deep sorrow and sympathetic condolence for the bereaved family and for the community of which he was such an outstanding part.

Whereas, we the delegates to the 34th National Conference on Weights and Measures have learned with regret of the death of $\mathrm{Mr}$. J. E. Woodland, one of our esteemed associates; and

Whereas, his passing will leave a serious gap in the ranks of weights and measures activities; Therefore be it

Resolved, That we the delegates and guests to the 34th National Conference on Weights and Measures do hereby express our deep sorrow and sympathetic condolence for the bereaved family, and for the community and company of which he was such an outstanding part.

\section{J. W. SAYBOLT}

Whereas, a beloved member of our weights and measures associates, J. W. Saybolt, has since our last meeting suffered an illness preventing. his attendance at this year's Conference; Therefore be it

Resolved, That the Conference Body formally express its heartfelt hope for an improved condition of J. W. Saybolt, and extend to hin its best wishes for a return to his full vigor and strength.

\section{APPRECIATION TO THE PRESS}

Whereas, The press of the City of Washington has been generous in reporting the activities of our present meeting; and

Whereas, The Scale Journal has likewise been generous in publishing news and advance notice of our present meeting; Therefore be it

Resolved, That this, the 34th National Conference on Weights and Measures, does hereby record its appreciation to the press of the City of Washington and to the Scale Journal.

\section{MEMORIAL SERVICES}

Whereas, between the annual conferences associates are called by the Supreme Weighmaster; and

Whereas, it should be recorded as an expression of sincere sorrow and regret of their passing; Therefore be it

Resolved, That during the opening session of each annual Conference on Weights and Measures, time be allotted to permit proper memorial service in eulogy in memory of those who have been called by our Creator.

\section{SPECIAL COMMITTEE ON UNIFORM REGULATIONS}

Whereas, it is the opinion of the delegates to the 34 th National Conference on Weights and Measures that uniform interpretation and enforcement of weights and measures laws and regulations is a necessity; and

Whereas, there is a real need for guidance in the drafting and adoption of uniform weights and measures laws and regulations; Therefore be it

Resolved, That the 34th National Conference go on record as favoring the creation of a committee consisting of five members, whose duties it will be to gather and present to the 35th Conference on Weights and Measures a program of ideas and examples of regula- 
tions that may be used by weights and measures officials throughout this country in preparing for these areas under their jurisdiction regulations of a nature and wording as to be uniform with these as prepared and adopted by their associates.
J. E. Brenton, Chairman,
C. A. BAKER,
J. M. BOUCHER,
H. F. Crawford,
J. M. Dietz,
J. W. ReEse,
L. E. WrTT,

Committee on Resolutions.

Mr. Brenton. Mr. Chairman, I move the adoption of these resolutions.

(The motion was seconded by Mr. Nelson, the question was taken, and the motion was agreed to.)

Mr. Rogers. I move that, in recognition of those who have left us, we stand in silent tribute for 1 minute.

(The Conference arose and observed 1 minute of silence in memory of deceased members.)

\section{REPORT OF THE NATIONAL CONFERENCE TREASURER, GEORGE F. AUSTIN, JR.}

May $15,1949$.

Balance on hand June 1, 1947 $\$ 477.71$

Receipts :

Sept. 25. Dues--1947 Conference_-_-_-_-_- $\$ 452.00$

Interest accrued

Disbursements :

Sept. 28. Social evening, Hotel Washington:
Music
Buffet lunch,250@\$1.50 each
125.00
Punch, 12 gal.@\$15.00 gal
375.00
Tips-waiters' service.
180.00
Rental-Hall of Nations
55.50
75.00
Amplifiers, social evening
10.00
Amplifiers,4days@\$10.00 day
40.00
Telephone service
1. 10
Movement of Conference material at hotel
2. 00
Messenger service
5.00
Mimeograph operators, $4 @ \$ 5.00$ ea
20.00
Registrar's,2@\$10.00 ea___._._._._._._._- 20.00
March 22, 1949, Receipt book
3.09

Balance on hand May 15, 1949

Respectfully submitted.

(Signed) Geo. F. Austin, Treasurer

Mr. Rogers. I move the adoption of the Report.

(The motion was seconded, the question was taken, and the motion was agreed to.) 
Mr. Rogers. I wish to make the customary motion authorizing the Treasurer to pay all necessary expenses of this Conference.

(The motion was seconded by Mr. Fraser, the question was taken, and the motion was agreed to.)

\section{REPORT OF THE NATIONAL CONFERENCE COMMITTEE ON NOMINA- TIONS, PRESENTED BY ERLING HANSEN, CHAIRMAN, AND ELECTION OF OFFICERS}

Mr. Hansen. The Committee on Nominations met in open session to receive suggestions from members of the Conference relative to nominations for office. No one appeared before the Committee for this purpose.

The Nominating Committee has voted unanimously to submit the following nominations for office in the National Conference for the ensuing year:

\section{OFFICERS}

For President: E. U. CoNdon, Director, National Bureau of Standards.

For Vice Presidents: J. E. Brenton, of Califoruia ; J. 'T. KENnEDY, of the District of Columbia; Joseph Leonard, of Paterson, N. J. ; C. A. Baker, of New York ;

C. C. Mundy, of Richmond, Va.; A. J. Jensen, of North Dakota.

For Secretary: RALPH W. SuITH, National Bureau of Standards.

For Treasurer: GEonge F. Austin, Jn., of Detroit, Mich.

\section{EXECUTIVE COMMITTEE}

For members of the Executive Committee: C. G. Crockert, of Baltimore, Md.; C. D. Link, of Baltinore County, Md.; E. R. Fisher, of Rhode Island; J. P. McBride, of Massachusetts; H. E. Howard, of Miami, Fla.; C. D. Baucom, of North Carolina; W. A. KerLIN, of Alameda County, Calif.; L. R. Roper, of Seattle, Wash.; A. F. Chappius, of Louisiana ; A.'T. Smith, of New Jersey; R. D. 'Thompson, of Virginia ; J. A. Bernard, of St. Louis, Mo.; C. H. OAKLey, of Wyoming; F. M. Greene, of Connecticut; I. M. LeVY, of Chicago, Ill. Respectfully submitted.

(Signed) ErLing Hansen, Chairman, E. J. JUDKINS, C. M. FULLER, J. G. Rogers, H. L. ShankLe, Committee on Nominations.

(It was moved by Mr. Fraser and seconded by Mr. Santimauro that the Report of the Committee on Nominations be adopted and that the nominees be declared elected; the question was taken, and the motion was agreed to.)

\section{NEW BUSINESS}

The Secretary. I wish to advise you on the organization of the standing committees of the Conference for the ensuing year, resulting from the actions of the several committees as reported to me.

On the Committee on Specifications and Tolerances the Chairman will be Mr. J. P. McBride and the Secretary will be Mr. R. W. Smith.

On the Committee on Methods of Sale of Commodities the Chairman will be $\mathrm{Mr}$. J. F. Blickley.

On the Committee on Legislation the Chairman will be Mr. R. E. Meek:

On the Committee on Weights and Measures Education the Chairman will be Mr. J. T. Kennedy and the Secretary will be Mr. W. S. Bussey. 
THIRTY-FOURTH CONFERENCE ON WEIGHTS AND MEASURES 169

It appears that the Committee on Trading by Weight has not organized, and I have no information as to who will be the Chairman for the ensuing year. ${ }^{7}$

Tue Chammin. There being no further business, I declare the Thirty-fourth National Conference on Weights and Measures adjourned sine die.

(Thereupon, at 1:10 p. m., the Thirty-fourth National Conference on Weights and Measures adjonrned sine die.)

7 The Secretary was subsequently advised that the Committee had chosen Mr. J. Fred True as Chairman for the ensuing year. 
